UNIVERSIDADE DE SÃO PAULO

FACULDADE DE FILOSOFIA, LETRAS E CIÊNCIAS HUMANAS

DEPARTAMENTO DE LETRAS CLÁSSICAS E VERNÁCULAS

PROGRAMA DE PÓS-GRADUAÇÃO EM LITERATURA BRASILEIRA

DOUGLAS FERREIRA DE PAULA

A crítica de Nestor Vítor na República Velha

VERSÃO CORRIGIDA

São Paulo 
UNIVERSIDADE DE SÃO PAULO

FACULDADE DE FILOSOFIA, LETRAS E CIÊNCIAS HUMANAS

DEPARTAMENTO DE LETRAS CLÁSSICAS E VERNÁCULAS

PROGRAMA DE PÓS-GRADUAÇÃO EM LITERATURA BRASILEIRA

\title{
A crítica de Nestor Vítor na República Velha
}

\author{
DOUGLAS FERREIRA DE PAULA
}

Tese de Doutorado apresentada ao Programa de Pósgraduação em Literatura Brasileira do Departamento de Letras Clássicas e Vernáculas da Faculdade de Filosofia, Letras e Ciências Humanas, da Universidade de São Paulo, como parte dos requisitos para obtenção do título de Doutor em Letras.

Orientador: Prof. Dr. Jefferson Agostini Mello

VERSÃO CORRIGIDA

São Paulo

2019 
Autorizo a reprodução e divulgação total ou parcial deste trabalho, por qualquer meio convencional ou eletrônico, para fins de estudo e pesquisa, desde que citada a fonte.

Catalogação na Publicação Serviço de Biblioteca e Documentação

Faculdade de Filosofia, Letras e Ciências Humanas da Universidade de São Paulo

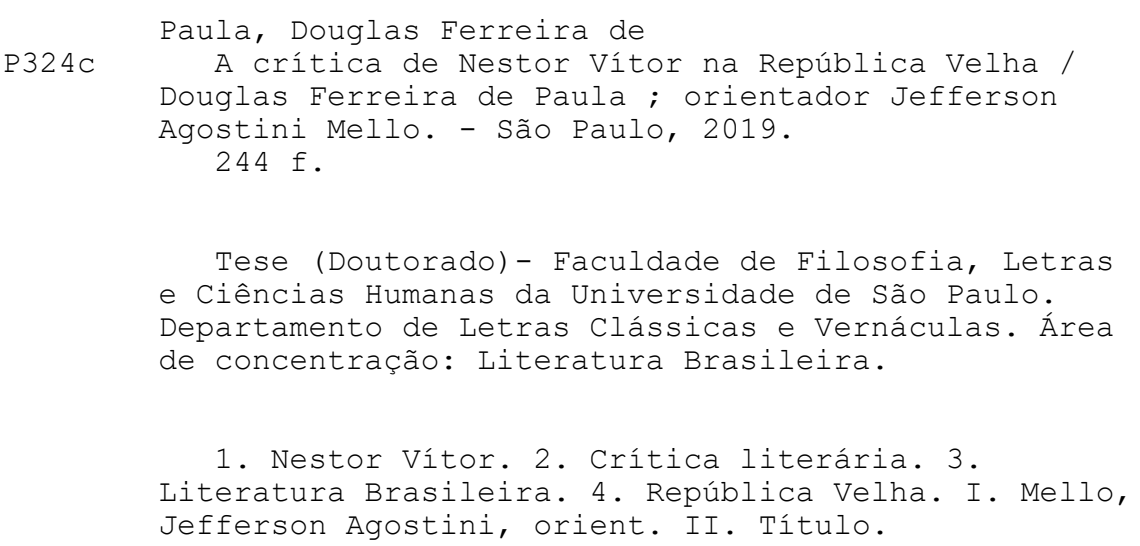

1. Nestor Vítor. 2. Crítica literária. 3. Literatura Brasileira. 4. República Velha. I. Mello, Jefferson Agostini, orient. II. Título. 
UNIVERSIDADE DE SÃO PAULO

FACULDADE DE FILOSOFIA, LETRAS E CIÊNCIAS HUMANAS

\& fflch

\section{ENTREGA DO EXEMPLAR CORRIGIDO DA DISSERTACCÃO/TESE}

Termo de Ciência e Concordância do (a) orientador (a)

Nome do (a) aluno (a): DOUGLAS FERREIRA DE PAULA

Data da defesa: $28 / 01 / 2019$

Nome do Prof. (a) orientador (a): JEFFERSON AGOSTINI MELLO

Nos termos da legislação vigente, declaro ESTAR CIENTE do conteúdo deste EXEMPLAR CORRIGIDO elaborado em atenção às sugestões dos membros da comissão Julgadora na sessão de defesa do trabalho, manifestando-me plenamente favorável ao seu encaminhamento e publicação no Portal Digital de Teses da USP.

São Paulo, $19 / 02 / 2019$

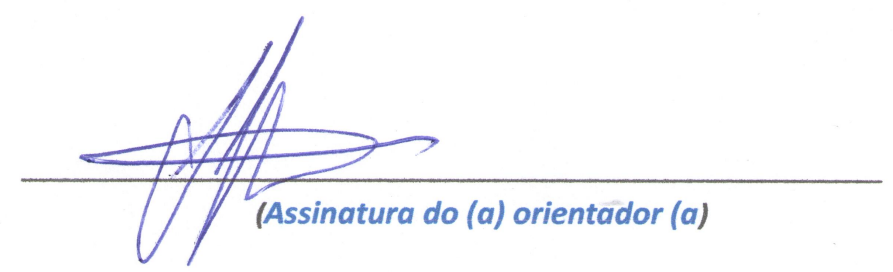


PAULA, D. F. A crítica de Nestor Vítor na República Velha. Tese apresentada à Faculdade de Filosofia, Letras e Ciências Humanas da Universidade de São Paulo para obtenção do título de Doutor em Letras.

Aprovado em:

Banca Examinadora

Prof. Dr. Instituição:

Julgamento: Assinatura:

Prof. Dr. Instituição:

Julgamento: Assinatura:

Prof. Dr. Instituição:

Julgamento: Assinatura: 


\section{AGRADECIMENTOS}

Ao Prof. Doutor Jefferson Agostini Mello pela orientação durante esses anos todos no Programa de Pós-Graduação em Literatura Brasileira, desde minha pesquisa em nível de mestrado.

Aos membros de minha banca de qualificação, os professores Doutores Vagner Camilo e Ricardo Souza de Carvalho pelas valiosas sugestões para a continuidade do trabalho.

À Universidade de São Paulo por participar de minha formação intelectual há mais de uma década.

À Universidade Federal do Amazonas e ao curso de Letras do Instituto de Educação, Agricultura e Ambiente pela liberação, a partir do ano de 2018, para qualificação profissional.

À minha família e aos meus amigos pela acolhida durante minha estada nessa caótica e bela São Paulo. 


\section{RESUMO}

PAULA, Douglas Ferreira de. A crítica de Nestor Vítor na República Velha. 2018. Tese (Doutorado em Literatura Brasileira) - Faculdade de Filosofia, Letras e Ciências Humanas, Universidade de São Paulo, 2018.

O presente trabalho consiste em uma leitura da Obra crítica de Nestor Vitor, publicada pela Fundação Casa de Rui Barbosa. Considerado pela historiografia literária brasileira como um importante crítico do simbolismo brasileiro, o estudo apresenta aspectos da trajetória sociocultural de Nestor Vítor dos Santos (1868-1932), analisando textos de sua produção intelectual, especificamente, aquela enquadrada como crítica literária. Pretende, desse modo, ressaltar algumas das linhas de força de seu pensamento no que se refere à leitura que fez de escritores nacionais e estrangeiros no período compreendido entre 1896 a 1930, logo, no interior do período conhecido como Primeira República ou República Velha (1889-1930). Apoiando-se em trabalhos já realizados acerca do crítico e do sistema literário nacional, a tese busca evidenciar as contribuições que sua obra fornece para entender a dinâmica do campo literário brasileiro, recorrendo, para isso, a aspectos da sociologia francesa de Pierre Bourdieu. Além de uma abordagem de elementos históricos e contextuais da vida e obra do crítico Nestor Vítor, a tese foca em três questões recorrentes de sua produção: a denúncia e a participação na "política literária" existente no meio cultural carioca, a relação com o movimento simbolista e, por fim, a aproximação crítica com autores que conformariam parte do movimento modernista brasileiro. A partir desse foco, vislumbra-se o papel de Vítor no interior da crítica literária, as estratégias de valorização ou desvalorização de obras e autores em seus escritos e a apreensão das disputas e valores em jogo no campo literário do período. Do conjunto das leituras realizadas, depreende-se uma visão mais complexa da obra de Nestor Vítor, contribuindo a pesquisa, assim, para enriquecer a história da crítica literária em nosso país.

PALAVRAS-CHAVE: Nestor Vítor. Crítica literária. Literatura brasileira. 


\begin{abstract}
PAULA, Douglas Ferreira de. The criticism of Nestor Vítor in the "República Velha". 2018. Thesis (Doctorate in Brazilian Literature) - FFLCH, Universidade de São Paulo, 2018.

The present work consists of a reading of the Obra critica de Nestor Vitor, published by the Foundation Casa de Rui Barbosa. Considered by Brazilian literary historiography as an important critic of Brazilian symbolism, the study presents aspects of the sociocultural trajectory of Nestor Vítor dos Santos (1868-1932), analyzing texts of his intellectual production, specifically, that framed as literary criticism. In this way, he intends to emphasize some of the strengths of his thought regarding his reading of national and foreign writers in the period between 1896 and 1930, then within the period known as "Primeira República" or "República Velha" (1889-1930). Drawing on works already done on the critic and the national literary system, the thesis seeks to highlight the contributions that his work provides to understand the dynamics of the Brazilian literary field, using, for this, aspects of the French sociology of Pierre Bourdieu. In addition to an approach to historical and contextual elements of the life and work of the critic Nestor Vítor, the thesis focuses on three recurring issues of its production: denunciation and participation in "literary politics" in the carioca cultural milieu, the relation with the symbolist movement and, finally, the critical approach with authors who would conform part of the Brazilian modernist movement. From this focus, sees the role of Victor inside the literary criticism, the valuation strategies or depreciation of works and authors in their writings and the seizure of disputes and values at stake in the literary field period. From the set of readings carried out, a more complex view of Nestor Vítor's work emerges, thus contributing to the research to enrich the history of literary criticism in our country.
\end{abstract}

KEYWORDS: Nestor Vítor. Literary criticism. Brazilian literature. 


\section{SUMÁRIO}

NOTA INTRODUTÓRIA........................................................ 10

1. EM TORNO DE NESTOR VÍTOR ........................................... 15

1.1. Vida, obra e aspectos do contexto histórico do final do século XIX ............. 18

1.2. Civilização e mundanismo nos primeiros anos do século $\mathrm{XX}$................. 33

1.3. Nacionalismo e espiritualismo nas manifestações culturais a partir da Guerra................................................................... 46

2. A "POLÍTICA LITERÁRIA”: INSTRUMENTO DE ANÁLISE DA CRÍTICA............. 58

2.1. A crítica no campo literário brasileiro: a parcialidade voluntária ...............58

2.1.1 A parcialidade da geração de 1870 entrevista por Vítor ................67

2.2. A expressão "política literária" ......................................... 78

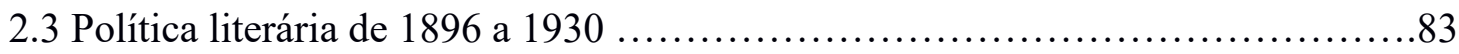

2.3.1. A monografia Cruz e Sousa ................................. 83

2.3.2. A etapa “combatente" na primeira parte de A Crítica de Ontem........ 90

2.3.3. Transição e intervalo entre 1902 a 1910 ..............................104

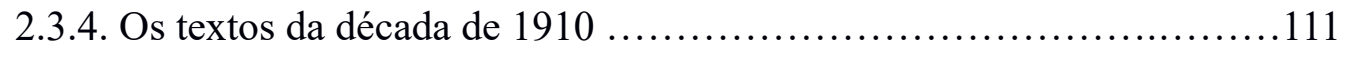

2.3.5. A revisitação do passado nos anos 20 ................................... 116

3. NESTOR VÍTOR E O SIMBOLISMO ........................................ 124

3.1. A historiografia em torno de Nestor Vítor ............................... 124

3.2. Levantamento sobre o simbolismo ....................................... 127

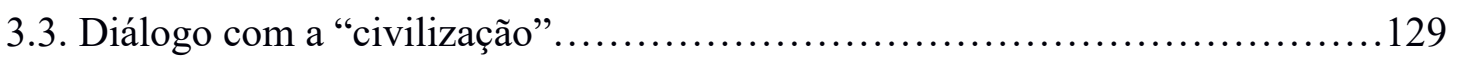

3.4. Momento de transição em torno do simbolismo .............................153

3.4.1 Cruz e Sousa e Emiliano Perneta: reavaliação do simbolismo a partir dos

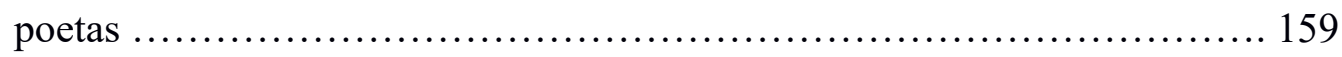

3.5. A arte ultrapassada pela moral ...................................... 173

3.5.1 O simbolismo lido como "reação espiritualista" ......................180

4. NESTOR VÍTOR E O MODERNISMO BRASILEIRO.............................201 
4.1. A apreensão do movimento modernista ....................................201

4.2. Alguns artigos de Os de hoje ........................................ 206

4.3 "Futuristas" e espiritualistas: a aposta de Vítor .............................215

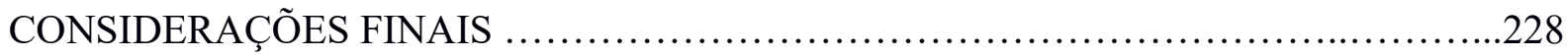

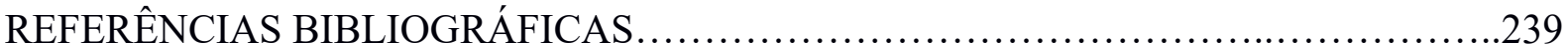




\section{NOTA INTRODUTÓRIA}

Nestor Vítor hoje é um nome praticamente esquecido nas letras nacionais. Figura em alguns poucos trabalhos acadêmicos e em alguns livros de crítica e história literárias. A pouca importância de seu nome, no entanto, não é a algo a ser lamentado. Reflete a própria dinâmica do sistema literário brasileiro em sua relação com o contexto histórico em que o autor produziu a sua obra.

Como apontou Luiz da Costa Lima (1981), a tarefa do crítico do século XIX não era uma das mais fáceis. De um lado, ele precisava difundir obras de autores nacionais e estrangeiros poucos lidos em virtude de um mercado editorial bastante restrito e, de outro, fundar uma tradição para o próprio comentário crítico dessas obras, logo, fundar uma tradição para a crítica literária.

A Geração de 1870, nesse sentido, foi exemplar por consolidar essa tradição e, por isso, até hoje recebe as maiores atenções da historiografia literária.

Nestor Vítor construiu a sua obra em diálogo com esse espaço crítico também em formação. Teria, além disso, contra a sua permanência nas letras, o fato de ter produzido às vésperas do movimento modernista que serviria de marco para a maior parte da crítica e da historiografia literárias no século XX, como se depreende da leitura de Wilson Martins (1983) ou de Antonio Candido (2006).

Por isso, o presente trabalho mais do que fazer uma revisão em torno do nome de Nestor Vítor, pretendeu apresentar a obra do crítico que teve toda a sua produção escrita no período da República Velha.

Com a leitura da Obra Crítica de Nestor Vitor, comecei também a reler a crítica da tríade da "Geração de 1870 " sob uma perspectiva mais compreensiva e busquei formular uma explicação para o que me pareciam ser as contradições na crítica de Nestor Vítor. Contradições ligadas as diferentes leituras que o crítico realizou, ao longo de décadas, sobre a obra do poeta Cruz e Sousa. Mais do que isso, com a leitura da obra de Vítor, pude expandir meu interesse pelas questões trabalhadas pelo crítico, buscando encarar a sua produção como significativa do período.

Olhando para esse período (fins do século XIX e início do XX) em que o campo literário não apresentava autonomia em relação aos demais campos da vida social ${ }^{1}$, relativizei

1 Como se verá ao longo do texto, trabalho com a noção de campo, apresentada em obras do sociólogo francês Pierre Bourdieu, como As Regras da Arte, A Economia das Trocas Simbólicas, A Distinção e 
algumas das considerações recorrentes da historiografia literária que encaravam Nestor Vítor apenas como um crítico do movimento simbolista.

Conquanto o simbolismo fosse central para pensar as escolhas e as posições que Vítor assumiu no interior da cultura do período, o estudo de sua obra crítica possibilitou olhar para a produção da chamada belle époque e do período pós Primeira Guerra Mundial encarando o espaço de criação e crítica de um modo mais amplo do que o possibilitado pela mera sucessão ou sobreposição de movimentos literários, típico de certa visão da história da literatura. De maneira que a filiação a esta ou aquela estética pareceu menos importante do que a reconstrução do sistema de relações simbólicas e não-simbólicas que o crítico manifestava na sua prática, representada por meio de seus textos.

Desse modo, o presente trabalho buscou, ainda que de forma não conclusiva, analisar as relações que Nestor Vítor contraiu com seu ambiente cultural, o que foi feito, sobretudo, por meio da leitura de sua obra crítica, entendida como tomada de posição no campo literário que se gestava.

Para tanto, utilizei-me da edição da Obra Crítica de Nestor Vitor, publicada em três volumes, pela Fundação Casa de Rui Barbosa, entre 1969 e 1979. O objetivo da leitura foi encontrar ideias, noções, expressões que materializassem as principais contribuições do crítico para o entendimento do período e do campo literário em formação.

Nesse sentido, o presente trabalho foi dividido em quatro capítulos, cada um dos quais buscando analisar a obra crítica de Nestor Vítor em relação a questões pertinentes tanto para entender o momento histórico quanto para reconstruir parte do sistema de relações do campo literário brasileiro.

Assim, o primeiro capítulo buscou relacionar a vida e a obra de Nestor Vítor com questões históricas ligadas ao surgimento da Primeira República e ao contexto cultural do Rio de Janeiro do início do século XX. Nele busco traçar um paralelo entre a existência do crítico e os problemas colocados pelo período. Divido a apresentação de sua vida e obra em três partes. A primeira corresponde ao seu período de formação, ao surgimento da República, ao nascimento da estética simbolista em nossas letras e às suas primeiras publicações, marcadas pelo contexto de final de século e voltadas sobretudo às referências estrangeiros da literatura "místico-simbolista", como então ele denominava. A segunda corresponde ao período em que a chamada belle époque consolida-se, compreendendo todo o início do século XX até meados

Meditações Pascalianas. Conferir referências bibliográficas e notas ao longo do texto. 
dos anos 10, quando estoura a Primeira Guerra Mundial. Trata-se de uma fase de "mundanismo" e de sobrevalorização da vida literária em detrimento da produção propriamente literária e época também em que Nestor Vítor começa a diversificar a sua produção crítica, escrevendo sobre escritores contemporâneos das mais diferentes tendências e, particularmente, sobre escritores brasileiros. A terceira e última parte do primeiro capítulo indica a produção de Vítor no período a partir da Guerra quando o simbolismo, bem como outras estéticas se lhe afiguram como passadistas e ele busca ou revisitar o passado, lançando balanços e análises sobre as disputas no campo, ou observar a nova produção literária, estabelecendo ligações com certos valores que ele supõe ser genuinamente brasileiros, como a tendência espiritualista do povo ou o nacionalismo literário dos escritores. Daí que, além de um bom panorama sobre os autores do passado, Vítor lança um olhar sobre os escritores vanguardistas que conformariam o movimento modernista brasileiro.

Feito o esboço do panorama histórico e cultural dos escritos de Vítor, parto, no segundo capítulo, para a análise de um conjunto de textos que permitem reconstruir o campo literário entrevisto por ele. Para isso, elejo como elemento interpretativo da crítica e da literatura na República Velha a expressão "política literária", utilizada explícita e implicitamente nos textos analisados.

Antes de mostrar a aplicação da expressão, estabeleço brevemente, no capítulo, o significado da crítica literária do período, reforçando a tese apresentada por muitos estudiosos de que se tratou muito mais de uma crítica de cunho cultural no sentido amplo do que uma crítica "literária" propriamente dita. Sem desmerecer tal crítica, busco demonstrar que Vítor também participou dela ainda que seja visto como um crítico impressionista pela historiografia. Argumento, ainda nas primeiras seções do capítulo, que não havia uma função diferente na crítica de Nestor Vítor em relação à tríade da crítica naturalista, mas uma posição diferente no campo cultural. Como crítico "secundário", "menor", Nestor Vítor pôde enxergar as disputas no interior do campo e apresentá-las como parte da constituição do fazer literário do período.

Dando prosseguimento, faço uma leitura do conjunto da obra de Vítor a partir dos indícios do que antes chamei de "política literária". Partindo da monografia Cruz e Sousa, publicada em 1899, mas escrita em 1896, procuro ir revelando as posturas críticas que ele foi assumindo ao longo da vida. Do crítico que defendia a "Religião da Arte", na primeira fase de sua produção, ao crítico que desvenda os laços entre política, economia e literatura, já no final 
da carreira, tento demonstrar como a política literária aparece ora como uma realidade a ser compreendida e denunciada ora como uma estratégia de ingresso e permanência no campo literário brasileiro.

No terceiro capítulo, com uma leitura já do campo a partir da perspectiva de Vítor, intento compreender o uso e a função que o Simbolismo teve na sua produção crítica. Para isso, divido o capítulo em cinco seções para levantar algumas questões que me parecem significativas tanto da apreensão que se fez do crítico pela historiografia quanto da sua própria produção. A primeira trata da ideia recorrente de o crítico ser o "crítico do simbolismo", imagem que a historiografia reservou ao crítico, reforçando a tese de isolamento da estética finissecular que exigia um "crítico saído do próprio movimento" e que o próprio Vítor endossou durante a sua fase de maior reconhecimento a partir de seus textos de balanços e rememorações. A segunda estabelece uma espécie de periodização em torno do simbolismo na obra de Vítor, reconhecendo que o modo de apreensão do movimento, da estética, das obras e dos autores não é idêntica do início ao fim de sua carreira. Há, ao menos, três "momentos" de apreensão do simbolismo que são apresentados e analisados nas seções seguintes do capítulo.

O mais conhecido e que melhor representa a imagem que se tem do crítico é o primeiro momento, ligado ao final do século XIX, quando ele apresenta os referenciais "civilizados" que conformavam a estética simbolista e indicavam os valores mais "elevado" dos escritores filiados a corrente "místico-simbolista". O segundo momento, caracterizado por mim como de "transição", representa o retorno de Paris, onde o crítico esteve por três anos, e o seu reingresso nas letras nacionais a partir de textos críticos sobre os mais diferentes autores, de todas as "escolas" literárias. Momento em que já há uma reavaliação do simbolismo, considerado como parte de uma estética enfraquecida, e no qual já se mesclam, em sua crítica, tanto os critérios anteriores de valorização da arte "elevada" quanto novos critérios, extraídos, alguns, da própria tradição crítica naturalista, como se verifica em sua revisão da leitura da obra de Cruz e Sousa. O terceiro momento, que é analisado nas seções finais do capítulo, encerra as transformações mais profundas de sua produção crítica, produzindo, na observação de conjunto, a imagem contraditória, mas bastante explicável, de sua obra. É o momento de adoção de critérios mais morais (a "reação espiritualista" ao qual se aproxima) e de retomada de certa tradição romântica de nossa literatura com a valorização do nacionalismo literário. $\mathrm{O}$ simbolismo lido como reação espiritualista combina-se, nessa fase, com a valorização dos temas de "cor local", reunindo, de forma aparentemente paradoxal, 
espiritualismo e nacionalismo e fundindo, em sua só tradição, como elos "naturais" de uma só corrente, romantismo e simbolismo.

Finalmente, no quarto capítulo, já considerando que Vítor foi mais do que um crítico do simbolismo, ou melhor, mais do que um crítico estrito do simbolismo, pois acompanhara mais de três décadas de produção cultural na República Velha, analiso o sentido da recepção que ele desenvolveu em torno dos escritores vanguardistas posteriores à Primeira Guerra Mundial e que conformariam o movimento modernista brasileiro. Dialogando também com certa visão que a historiografia apontou em Nestor Vítor, busco demonstrar que a sua atitude em relação ao movimento modernista foi uma atitude ambivalente, porque, de fato, propôs-se a ler os escritores da nova geração, observando os reflexos das novas estéticas, mas, ao mesmo tempo, manteve um olhar sobre o passado, lendo os novos escritores como atores das antigas disputas no campo literário brasileiro.

Assim, por um lado, atento às novas criações literárias, Vítor buscou encontrar nelas o que havia de inovador, mas também o que havia de tradicional, no que se referia à busca do “nacional" (algo que ele fazia desde meados dos anos de 1910); por outro, ainda imbuído de certo espírito de coterie, busca delinear os espaços e os valores dos novos escritores diante das demandas do tempo, separando as alas modernistas segundo as experimentações linguísticas e o que ele supunha ser as tendências "objetivistas" ou "subjetivistas" em arte.

Com esse olhar, acabou por apostar na corrente espiritualista dos novos escritores, opondo, assim, de um lado, o grupo que se reuniria em torno da revista Festa e, de outro, o grupo dos chamados "futuristas", encabeçados por Mário de Andrade e Oswald de Andrade, mostrando inequívoca preferência pelos primeiros, confirmando aí sim certa imagem que a historiografia fez dele em sua fase final, a de um escritor já passadista. Representação que, em última instância, ele próprio não chegou a rejeitar ao longo dos anos de 1920, o que revelava consciência de que a sua "hora" já não era mais a atual e precisava de qualquer forma investir em novos escritores, a exemplo de Tasso da Silveira ou Murilo Araújo. Autores muito presentes em seu último livro, já póstumo, de 1938, Os de Hoje, mas que não seriam, como sabemos, os autores mais consagrados dessa fase inicial do modernismo brasileiro. 


\section{EM TORNO DE NESTOR VÍTOR}

O poeta, contista e crítico literário Nestor Vítor dos Santos nasceu em 12 de abril de 1868, na cidade litorânea do Paraná, Paranaguá. Como um autor que pouco interesse suscitou nos estudos historiográficos e críticos ao longo do século $\mathrm{XX}$, seria a princípio de menor relevância adentrar em aspectos de sua biografia, passando-se logo ao que parece ser a sua maior herança: a relação com o movimento simbolista e, particularmente, com o poeta Cruz e Sousa, de quem foi amigo, crítico e inicialmente maior defensor da obra.

A constatação, em parte verdadeira, do somenos da vida do crítico paranaense, que não realizou grandes feitos, não participou de calorosas polêmicas e sempre manteve o tom cordial, mesmo quando ironizava, desdenhava ou entrava em embate com algum outro homem de letras do período, e que passado os anos de seu reconhecimento entre a Grande Guerra e a instauração da Segunda República, teve sua memória gradativamente esquecida dos meios intelectuais, como muitos outros que viveram a Primeira República e a belle époque carioca, talvez sirva para pensarmos o próprio significado do período.

Em geral, uma historiografia literária não é feita apenas dos grandes momentos e nomes consagrados. Reconstituir o discurso e o espaço dos que foram esquecidos ou daqueles que foram os "menores" pode nos permitir observar com mais acuidade a própria cultura de que somos tributários, revendo, quiçá, o significado também daquilo que foi consagrado e valorizado como tradição no interior de um campo específico, como o campo literário.

Assim, alguns trabalhos já foram realizados em torno da obra crítica de Nestor Vítor. Embora não seja um nome desconhecido no interior da historiografia das letras nacionais, ele ainda é, como disse, pouco estudado.

Em formato de livro, conheço apenas o trabalho de Alessandra de Carvalho, Nestor Vitor: um intelectual e as ideias de seu tempo, que busca relacionar aspectos da obra do crítico com o contexto histórico, levantando alguns temas, como o surgimento do simbolismo e a ideia do "espírito nacional", a partir da perspectiva do autor apresentada por meio da leitura de alguns de seus textos críticos.

Fora esse livro, há referências ao pensamento crítico de Nestor Vítor no primeiro volume de Panorama do Movimento Simbolista Brasileiro, de Andrade Muricy, ao longo das 
páginas de "Introdução". Aliás, Muricy, o "historiador do simbolismo" é, em geral, a fonte de informação biobibliográfica da maioria dos textos sobre Nestor Vítor.

Ainda em torno das ideias do crítico, aparecem notas, trechos e comentários dos seus trabalhos nos estudos da pesquisadora Vera Lins, como em Novos Pierrôs, velhos saltimbancos: os escritos de Gonzaga Duque e o final do século XIX carioca. Assumindo um intuito mais centrado na crítica literária do final do século, aparecem amplas citações dos textos do autor em A Recepção Crítica: o momento parnasiano-simbolista no Brasil, de Salete de Almeida Cara. Podemos ainda encontrar frases e parágrafos sobre o crítico em obras de historiografia literária, como o primeiro volume de A crítica literária no Brasil, de Wilson Martins ou o livro de Alfredo Bosi, História concisa da literatura brasileira.

Entretanto, os trabalhos que mais se debruçaram sobre os textos críticos de Nestor Vítor não foram publicados. Trata-se de trabalhos acadêmicos: duas dissertações de mestrado e duas teses de doutorado ${ }^{2}$. Entre eles, o mais amplo por tratar de toda a obra crítica publicada em livros de Nestor Vítor é a tese de doutorado de Allan Vallenza da Silveira, Diálogos críticos de Nestor Vitor ${ }^{3}$.

O conjunto desses livros e trabalhos será utilizado ao longo dos capítulos, estabelecendo-se diálogo com a fortuna crítica do autor pesquisado. O que interessa de imediato, no entanto, é revelar que Nestor Vítor, estabelecido na historiografia como o "crítico do simbolismo", foi sendo esquecido como as dezenas de escritores que surgiram e sumiram durante os anos de 1890 a 1930, que correspondem ao período da República Velha.

As razões desse pouco interesse podem ser mais ou menos óbvias: o tipo de crítica realizada (considerada pela maioria absoluta dos estudiosos como "impressionista" e, portanto, "não científica", sendo assim abandonada ao longo do século XX); o universo da crítica de então, voltado a autores que não criaram "raiz" no interior do sistema literário brasileiro, com exceção da crítica sempre retomada em torno de Cruz e Sousa; o contexto cultural visto como de transição às mudanças significativas que viriam com a forte industrialização do país, não vivenciadas pelo autor; a pouca importância dada na crítica do

2 As de mestrado são: A evolução do pensamento crítico de Nestor Victor n'A crítica de ontem, de Rosana Gonçalves e Nestor Vitor: a atividade crítica como e enquanto projeção de um modelo ideológico, de Maria Aparecida Roncato. As de doutorado: Nestor Vitor: contribuições teóricas, críticas e históricas, também de Rosana Gonçalves e Diálogos críticos de Nestor Vitor, de Allan Valenza Silveira, cujas referências completas encontram-se em Referências Bibliográficas.

3 Defendida em 2010 e apresentada no Programa de Pós-Graduação em Letras da Universidade Federal do Paraná, tendo sido orientada pela professora Marta Morais da Costa. 
mesmo aos "futuristas paulistas" (o núcleo modernista ligado a Mário de Andrade e Oswald de Andrade), etc.

Não obstante esses motivos, com o estabelecimento do simbolismo no interior de nossas letras, era de se esperar o reconhecimento do papel que o crítico Nestor Vítor desempenhou no campo literário para a consagração do movimento. Contudo, parece subsistir a tese de que a "genialidade" de Cruz e Sousa e a força lírica de um ou outro dos simbolistas mais cedo ou mais tarde viria à luz, sem que houvesse no período uma tenaz tentativa de romper os círculos da literatura oficial de então; existindo tais obras e autores como dados brutos a serem dilapidados pelos críticos das décadas posteriores.

Não me parece que o processo histórico tenha se dado assim. O breve, mas hoje estudado, movimento simbolista no país deve a figuras como Nestor Vítor e Andrade Muricy muito da difusão e do espaço que conquistou. A própria corrente espiritualista de que se acercou Nestor Vítor no final da vida teria papel importante junto aos chamados futuristas na batalha contra os parnasianos ainda triunfantes da década de 20 , conforme nos indica Antonio Candido no texto "Literatura e Cultura de 1900 a 1945", ainda que, segundo Candido, os espiritualistas, última expressão do simbolismo já ultrapassado, também fossem ser superados pelos modernistas de 22 (CANDIDO, 2006, p. 124-5).

Por essa razão, voltar-se tanto ao crítico Nestor Vítor que também, segundo Candido, no texto citado, segue a tendência de passar do "historicismo à crítica estética" (ibidem, p. 124) quanto ao período em que produziu sua obra teria de imediato um interesse para aqueles que buscam entender a formação de nosso sistema literário e a incorporação do simbolismo como parte do mesmo.

Assim, em uma primeira perspectiva, discutir a obra crítica de Nestor Vítor é irremediavelmente tratar do movimento simbolista no Brasil e do contexto de seu surgimento na cultura e na sociedade do final do século XIX e início do XX.

Com efeito, apresentarei a leitura e a análise da Obra Crítica de Nestor Vítor, publicada pela Fundação Casa de Rui Barbosa, com a percepção de que o autor buscou ao longo de sua vida construir um discurso de defesa do movimento, de seus valores, respondendo aos críticos e aos leitores da época. Mesmo quando já era reconhecido no meio cultural do Rio de Janeiro, a partir da Grande Guerra de 1914, o escritor continuou vez ou outra fazendo referências ao movimento simbolista, defendendo autores alinhados a esta 
estética e buscando construir uma narrativa de tradição para a tendência literária que Cruz e Sousa e outros escritores como ele adotaram em vida.

Entretanto, além dessa perspectiva primeira e plausível, em um segundo plano, apresentarei a obra crítica de Nestor Vítor a partir das discussões sobre a autonomia e as "regras" do campo literário brasileiro e sobre o próprio estatuto do crítico e sua relação com as disputas no meio cultural. A forma, por exemplo, como essas questões se entrelaçam em dado período histórico serve para avaliar as dificuldades da produção artística em um meio cultural restrito como o da República Velha.

Desse modo, sistematizo uma leitura da obra crítica de Nestor Vítor ressaltando as discussões acima mencionadas, proporcionando uma visão mais ampla do que deixou esse crítico para o período e como o seu olhar pode ainda nos servir para reflexões atuais em torno da crítica e de nossa história literária.

Para tanto, inicio com a apresentação da biografia do crítico e de aspectos do contexto histórico. Se sua biografia em si pode não ter relevância, o que ela objetiva das manifestações da formação social e cultural do período talvez o tenha.

\subsection{Vida, obra e aspectos do contexto histórico do final do século XIX}

Jeffrey Needell, em Belle Époque Tropical, começa sua investigação sobre a relação entre história sociocultural das elites e o Rio de Janeiro ao esboçar a "realidade nacional e urbana com a qual se defrontavam os cariocas" (NEEDELL, 1993, p. 19). Para ele, a compreensão inicial dessa relação começa trinta anos antes de 1898, quando, no governo Campos Sales, conforme o estudioso, iniciar-se-ia a belle époque.

Seguindo Needell, apontarei elementos históricos com os quais também se defrontou Nestor Vítor, nascido exatamente em 1868 e que teria contato com tais elementos da realidade não só porque passaria pelo Rio de Janeiro em 1888 para estudos e nele residiria definitivamente a partir de 1891, mas porque a cidade do Rio, além de ser a capital do Império e depois da República, era, de fato, a capital cultural do século XIX no Brasil, repercutindo sua importância para o restante do país.

A guerra do Paraguai (1865-1870), sem dúvida, serviu para catalisar mudanças que se vinham projetando desde o início do terceiro quartel do século e que repercutirão na política do país na década de 80 . Tais mudanças, no entanto, não abalaram a estrutura socioeconômica 
do país que ainda preservava dois estratos fundamentais (os senhores de terra e a massa de escravos e seus descendentes) e sua estrutura política correspondente (a centralização por meio de dois partidos oficiais e a existência da família real). Os fazendeiros decadentes do Nordeste e das regiões também precárias de Minas Gerais deslocavam seu poder para as grandes fazendas de São Paulo, faixas do Rio de Janeiro e de Minas Gerais, mantendo a escravidão como fator econômico fundamental. Espremido por essa dinâmica de classe, sobreviviam as camadas intermediárias, de profissionais liberais, comerciantes e burocratas do Estado.

A vida econômica, conforme Needell, estava concentrada nas áreas costeiras ainda no terceiro quartel do século. Paranaguá, cidade natal de Nestor Vitor e a primeira a ser fundada no Paraná, com um porto local significativo já no século XIX, deve ter se beneficiado de sua localização geográfica, permitindo algum desenvolvimento urbano, sem contudo suplantar a capital, Curitiba, onde Nestor Vítor realizou em 1885 os estudos preparatórios no Instituto Paranaense, embora tenha realizado o curso primário a partir de 1875 na sua cidade natal ${ }^{4}$.

Esses primeiros anos da vida do Vítor podem ter sido influenciados não só pelo clima geral de mudança que já se vislumbrava em jornais oposicionistas ao regime monárquico e à escravidão, mas também pelo contato com abolicionistas e republicanos nas escolas em que o jovem passou, conforme nos afirma Andrade Muricy na "Introdução" ao volume I da Obra Crítica de Nestor Vitor. Sabe-se, porém, que foi apenas no último quartel do século que os regimes monárquico e escravocrata começaram a ruir à luz do dia. Ruínas que não alterariam a estrutura econômica do país, segundo Needell.

(...) Mesmo com as eventuais transformações no ritmo do trabalho, no nível da tecnologia, no grau e complexidade da atividade empresarial, permanecia a antiga ordem social - constituída de uma restrita elite agroexportadora, uma massa de trabalhadores escravos e uma pequena camada de setores médios -, ordem esta derivada de uma sociedade latifundiária voltada para o abastecimento do mercado internacional (NEEDELL, 1993, p. 20).

Os sinais de modificação dos tempos ocorriam, todavia, com o crescimento das cidades onde "ganhava ímpeto a contestação política, com suas conspirações, revoltas urbanas e predileção por modelos europeus de mudança, cujas primeiras manifestações remontavam ao final da época colonial" (ibidem, p. 20).

4 Informações extraídas de Swami Vivekananda, em Alma e coração de Nestor Vitor, 1973. 
Não foi, portanto, por algum papel pioneiro que uma cidade provinciana como Paranaguá (que, afinal de contas, era um pequeno entreposto comercial) viu também surgir tendências contestatórias ao regime monárquico, com a formação em 1887 do Clube Republicano, do qual Nestor Vitor será seu primeiro secretário. Estamos às vésperas da derrubada do regime monárquico. Da mesma maneira, em 1888, em Curitiba, nosso autor também será eleito Secretário da Confederação Abolicionista do Paraná, participando mais das manifestações comemorativas pelo fim da escravidão do que propriamente nas lutas que as precederam.

Republicano e abolicionista, o percurso de formação de Nestor Vitor de 1868 a 1888 corresponde ao que Needell identifica no período como contestação intermitente à "antiga ordem" (ibidem, p. 20). Um estado de contestação que deveria atingir o grosso das camadas médias e da intelectualidade, sobretudo, daquela afastada dos poderes centrais. Situação talvez análoga à que viveu Cruz e Sousa em Nossa Senhora do Desterro, hoje Florianópolis.

A mudança temporária de Vítor para o Rio de Janeiro ainda em 1888 para frequentar o curso preparatório do Externato João de Deus, que seria um passo para ingressar no Curso Anexo da Escola Politécnica, não resultou em sucesso, o que o fez retornar a Curitiba. Apenas em 1891 fixaria moradia no Rio de Janeiro.

O curioso na situação política do país foi o engajamento da jovem intelectualidade que então surgia. Tal engajamento influenciou a vida de Nestor Vítor que buscou ter uma postura aparentemente coerente com os princípios que ora defendia. Conforme relatado por Andrade Muricy, o jovem abolicionista e republicano poderia ter permanecido em Curitiba com um bom cargo público, já que, em 1889, fora convidado "para oficial de gabinete pelo Governador do Estado, Américo Lobo Leite Pereira, ao que não anuiu por divergências políticas, indo dirigir o Diário do Paraná, oposicionista" (MURICY, in: VÍTOR, Obra Crítica, volume I, p. X) ${ }^{5}$. Como se percebe, o episódio reflete algo do clima político do período.

As divergências e as oposições aparecem nos jornais e expressam as rachaduras da própria estrutura política e econômica que precisava alterar-se de forma. Needell afirma que uma mudança significativa no período de 1868 a 1888 resultava da pressão das novas elites, sobretudo, da paulista, por ocupações na vida pública, nos cargos e nas funções do Império.

5 De agora em diante, para facilitar a leitura, as referências às obras críticas de Nestor Vítor serão feitas com a omissão de seu nome, a abreviação do título e a indicação do volume da citação; nesse caso, por exemplo, OC, vol. I, p. X. 
As velhas elites radicadas no Nordeste e faixas do Rio de Janeiro impunham, por exemplo, restrições aos bacharéis dos demais estados em ocupar cargos públicos "em uma época na qual o número absoluto de colocações aumentava de modo muito lento" (NEEDELL, 1993, p. 21).

Se formos pensar essa situação em termos de conquista de um lugar no funcionalismo público do Império, entenderemos o que significava a frustração dos jovens provincianos que chegavam à capital do país em busca de colocação profissional. As cartas de recomendação dos figurões das províncias tornavam-se cada vez menos significativas com o aumento do número de bacharéis, formados agora pelas faculdades existentes no país.

Se a nova elite paulista pressionava por mudanças, imaginemos a situação dos indivíduos do Sul, com sua menor importância no quadro geral da economia e da política nacionais. Imaginemos a situação de um Cruz e Sousa, filho de ex-escravos, buscando a consagração literária na capital após dissabores em sua terra natal ${ }^{6}$; ou de Nestor Vitor que foi bater a porta de muitos, inclusive, de parnasianos já conhecidos para obter um emprego na capital.

\footnotetext{
Nestor Vítor levou para o Rio de Janeiro a alguns daqueles parnasianos cartas de apresentação assinadas por Emílio de Menezes, seu conterrâneo, que lá estivera e travara relações antes dele. Foi, desta forma, acolhido pelos parnasianos e com eles conviveu nos seus primeiros anos na grande capital.

(...)

Olavo Bilac, por exemplo, um dentre aqueles a quem Nestor Vítor levara uma carta de apresentação, recebeu-o muito bem, produzindo-se entre ambos uma profunda simpatia. (...) (CARVALHO, 1998, p. 7-8).
}

A situação de muitos desses moços remediados que chegavam ao Rio de Janeiro provavelmente serviria de base para as agitações mais radicais do republicanismo que estava para se instalar. Resumindo esse período anterior à queda da monarquia e que coincide com o nascimento e a juventude de Nestor Vítor, Needell afirma: "Foram essas mudanças de grande amplitude, portanto, que as instituições da Monarquia tiveram de enfrentar após 1868. O desafio seria lançado por dois movimentos políticos: o republicano e o abolicionista (NEEDELL, 1993, p. 22).

6 Embora bem quisto por figuras importantes como o senhor Francisco Luís da Gama Rosa, então presidente da Província de Nossa Senhora do Desterro, Cruz e Sousa sofre os preconceitos raciais ao longo da década de 1880 em sua terra, como o não convite a festas e a recusa para que se tornasse promotor em uma cidade do interior do Estado, situações que devem ter contribuído para tentar a sorte no Rio de Janeiro. Conferir a introdução de Andrade Muricy à Obra Completa de Cruz e Sousa (2000). 
Como se vê, Nestor Vítor nasceu e se formou em um contexto social de transformação, de transição. O impacto dessa transformação e transição não faria parte das marcas também de sua crítica? Refiro-me à transição entre formas literárias que se diluem (o parnasianismo tornado acadêmico e o pós-naturalismo enlanguescido, segundo Candido, no estudo já citado) e outras (as simbolistas) que precariamente tentam se firmar mas que convivem com o passado e logo serão pressionadas por "modas" estrangeiras já no início do século XX. A formação social transitória de que Nestor Vítor participou não resultaria em um projeto crítico (e também literário) transitório, fadado não ao completo esquecimento, mas a uma realocação cada vez mais marginal?

Nessa hipótese, Nestor Vítor, um republicano e abolicionista "histórico", aparece circunscrito em uma época de conflito que levaria ao fim da escravidão e da monarquia, porém não a transformações profundas nas estruturas econômicas e sociais do país, permitindo que certos traços conservadores ressurgissem com força em seu discurso no período da Grande Guerra, o que demonstra que acabou por incorporar as próprias limitações ideológicas do período de que era tributária a sua formação, manifesta em alguns de seus textos.

Parece-me importante trazer já aqui dois extratos de seu texto de 1917 sobre o pensador cearense Farias Brito. O primeiro sobre o caráter desagregador da República e o segundo sobre o caráter "abrupto", "anárquico”, da Abolição.

\footnotetext{
A mudança da Monarquia para a República produziu efeito na multidão, é certo, mas foi apenas um efeito anárquico, com que elas simpatizaram, como se diz em medicina, por suas tendências ancestrais, vindas do negro e do silvícola. A obra do 15 de Novembro fez-nos retrogradar para a situação revolucionária em que se achou o país desde 1817 até quase 1850, falando-se apenas do período mais agudo (OC, vol. I, p. 231).
}

O determinismo das raças que é condenado nos escritos de mocidade de Nestor Vítor surge aqui como explicação para a aceitação da República pelo povo. Pensamento também contraditório com o que ele expressa, na prática, nos primeiros anos da República.

No contragolpe de Floriano Peixoto contra Deodoro da Fonseca e na Revolta da Armada, Nestor Vítor colocou-se ao lado dos florianistas. A simpatia não era de "negro" ou "silvícola" mas de alguém que se posicionava aparentemente ao lado dos republicanos radicais que esperavam maior participação civil e uma democracia mais voltada aos estratos 
médios da sociedade, ainda que, para sua instauração, ela viesse sob a violência do militar Floriano Peixoto.

Sobre a Abolição, suas palavras de 1917 demonstram ainda maior capitulação a certo pensamento conservador que deveria ter sido expresso muitas vezes durante os anos 80 e 90 do século XIX.

\begin{abstract}
A Abolição, feita do modo abrupto por que se fez, concorreu para modificar bastante a nossa ética, para destruir-se em muito boa parte o pouco de cristalização que játínhamos conseguido em tal sentido. O mais grave é que ela entrava em equação por esse modo dissolvente quase que já na hora em que mais íamos necessitar de efetiva cultura par fazer face às exigências de um regime puramente democrático (ibidem, p. 232)
\end{abstract}

A ideia de que Abolição fora abrupta ou ocorrera precocemente sem que se tivessem amadurecidas certas condições provavelmente existiu no pensamento da velha elite que ainda não podia substituir a mão de obra escrava pela assalariada. Desse modo, as reflexões assim soltas de Nestor Vítor em um texto que trata do elogio ao pensamento idealista de Farias Brito representam reverberações das contradições com as quais o homem de letras conviveu no final de século XIX e que ressurgem em um período de conflito mundial que foi a Primeira Guerra e, com ela, a explosão da Revolução Russa.

Tais ideias conservadoras tendo "sobrevivido" no pensamento de Nestor Vítor após décadas indicam como as mudanças da República não foram suficientemente profundas; indicam também contradições do pensamento da elite intelectual do período. Note-se, por exemplo, que a Abolição entra em conflito com a República na lógica do autor. Como se, como advento da República, que, aliás, é posterior a Abolição, a "anarquia" social desta se tornasse mais evidente e mostrasse seu caráter "precoce".

Com efeito, a subordinação da Abolição à existência da República revela, na realidade, uma diferença de valor. Provavelmente atribuída às posições das elites que se atritavam no comando do Estado nas crises por que viveu a República nos seus primeiros anos. As camadas médias da sociedade oitocentista, impossibilitadas de participarem ativamente na disputa de poder, acabavam por refletir os interesses materiais das frações dominantes que se atritavam. A subestimação da questão abolicionista, que era economicamente mais central do que a instauração imediata da República, pode encontrar sua explicação aí.

Os membros da nova elite de fazendeiros paulistas viram na República uma redistribuição do poder mais favorável a seus interesses regionais. Eles vislumbravam uma federação descentralizada, na qual cada unidade desfrutaria da 
receita que gerasse e seria governada por representantes eleitos pela elite local. A influência desses membros entre os fundadores do partido foi a causa provável do oportuno esquecimento da questão abolicionista (NEEDELL, 1993, p. 23).

Com isso, não quero afirmar que Nestor Vítor tenha se colocado contra a Abolição ou repudiado seus efeitos, de forma retardada, tardia, mas que seu discurso na idade madura assimila elementos de uma ideologia conservadora que deve ter se difundido no final do século XIX em razão das crises por que passou a República Velha e que reapareciam de alguma forma sob as ameaças cada vez mais concretas da luta de classes mundial que se projetava no país com aqueles dois grandes eventos: a Guerra e a Revolução Russa.

A ligação entre o contexto histórico, as defesas políticas da juventude e o pensamento da vida adulta servem para demonstrar o caráter dinâmico das ideias e como as direções do pensamento de Nestor Vítor não avançaram apenas para um ponto determinado, como "terra conquistada"; sofreram, naturalmente, as oscilações do período e das regras do campo em que se encontravam, seja o campo político, cultural ou propriamente literário.

De qualquer forma, a sua adesão, como da maioria da intelectualidade do país, à causa abolicionista originava-se da sua posição de setor intermediário urbano que contrastava com as elites rurais.

O maior conflito, talvez, na formação do pensamento político do crítico Nestor Vítor, estivesse na sua adesão a uma ala do republicanismo, mais radical, conhecida como jacobina, conforme nos assegura Silveira (2010). Ala republicana que se formara nas mentalidades dos oficiais da Escolas militares do Rio de Janeiro (A Escola Militar e a Escola Central rebatizada de Escola Politécnica em 1874) e que se alimentava, sem dúvida, do ideário do cientificismo e do positivismo em voga, oriundo da Europa (NEEDELL, p. 27), sem se coadunar, assim, com o espírito "aristocrata" e mesmo antipopular do movimento simbolista francês.

Segundo Silveira (2010), Nestor Vítor, na verdade, assumiu duas facetas derrotadas historicamente, mas que, em seus contextos de origem, eram conflitantes.

Nesse jogo de posições sociais, Nestor Vítor assume duas facetas: a faceta política, pouco manifestada em sua crítica, devido ao fato de que, quando começou a escrever, o grupo a que se filiara, os jacobinos, estava sendo afastado do poder, o que fez com que a sua atuação política fosse mais presente antes de iniciada a sua produção crítica; e a faceta estética marcada pela escolha dos pressupostos simbolistas e impressionistas. (...) Ao negar os valores políticos e econômicos decorrentes do Império, acabou por negar, também, as posturas estéticas desenvolvidas nas últimas décadas do segundo reinado, contrapondo-se, assim, às posturas parnasianas e naturalistas, e ao posicionamento cientificista da Escola de 
Recife de Sílvio Romero e Tobias Barreto. Da mesma forma, quando as ideias simbolistas vieram da França para o Brasil, e encontraram aqui repercussão (mesmo que limitada), não vieram puras. Se na França as ideias simbolistas eram um contraponto ao posicionamento político universalizante - de caráter democrático pregado pela Terceira República (de expansão dos direitos políticos e da educação), contraponto marcado pela crença na incomunicabilidade e no ataque ao mundanismo, o que chega aqui traz consigo os valores políticos da própria Terceira República, assumidos como por boa parte do grupo simbolista - ou de inspiração simbolista -, na sua maioria, inclusive, incorporada aos quadros burocráticos do Estado na recém-proclamada República brasileira (...) (SILVEIRA, 2010, p. 31-2).

De fato, modificado o terreno das ideias, elas ganharam outra conotação social. O simbolismo em nosso país seria identificado com os setores "marginalizados" da intelectualidade pequeno burguesa no restrito mercado das letras e a sua "aristocracia", tantas vezes repetida por Nestor Vítor em seus escritos, será, de fato e somente, uma "aristocracia de espírito".

Por conseguinte, a realidade das mudanças no país levou a que o radicalismo político (com o programa de maior participação das camadas médias urbanas) fosse gradativamente abandonado, de modo que os intelectuais se adaptassem aos interesses das novas elites que ascendiam ao poder, sobretudo, a nova elite paulista, sem que houvesse ascensão de parte majoritária da população.

O período de formação intelectual e política de Nestor Vítor na sua fixação definitiva no Rio de Janeiro correspondeu aos anos mais turbulentos do regime republicano. Não existiu, assim, uma perfeita correspondência entre as ideias políticas, avançadas e progressistas para o momento, e as estéticas, aparentemente elitistas. O caráter progressista ou "aristocrático" das ideias alterou-se a partir dos acontecimentos vivenciados.

Entre os anos de 1893 e 1899, por exemplo, quando o crítico vê surgirem os livros do poeta negro, quando escreve o texto de crítica Cruz e Sousa, quando publica seu livro de contos Signos, e quando prepara os demais textos de crítica que seriam publicados no livro $A$ hora, em 1900, o autor também presencia a Revolta da Armada, ficando ao lado do governo de Floriano Peixoto, o conhecido "Marechal de Ferro" como se popularizou pela violência investida contra os adversários, e também presencia a recomposição do poder das elites rurais na figura de Deodoro da Fonseca e, em 1897, acompanha a tentativa do assassinato deste por um oficial jacobino, que levaria a morte de um Ministro de Estado.

Embora identificado com os valores purificadores e "modernizadores" de seus jovens colegas militares, Floriano obteve surpreendente êxito na persuasão de civis de mentalidade semelhante. Seus seguidores foram chamados tanto de jacobinos (nome inspirado nos jacobinos da Revolução Francesa) quanto de florianistas. Eram 
oficiais subalternos, cadetes, burocratas e funcionários públicos dos escalões inferiores, estudantes, profissionais liberais, empregados de escritórios, jornalistas e similares (NEEDELL, p. 32).

Em outras palavras, mesclam-se em suas posturas a adesão a uma estética considerada elitista e estrangeira com o apoio a uma ala do republicanismo, considerado radical. Se o movimento estético a que aderira não conseguiu boa repercussão, a sua adesão aos florianistas, no entanto, não foi de todo derrotada, embora esta tendência política o seria nos próximos anos. Segundo Muricy, a adesão ao florianismo rendeu a Nestor Vítor a possibilidade de estabilizar-se no Rio de Janeiro com um cargo público.

(...) Floriano Peixoto nomeia-o, em 22 de junho de 1894, Vice-Diretor do Internato do Ginásio Nacional, depois Colégio Pedro II, onde lecionou várias disciplinas do curso de Letras. Teve, ali, como colegas de magistério, Sílvio Romero e João Ribeiro. Passou a colaborar em O País, convidado pelo seu diretor, Quintino Bocaiúva. Com José Veríssimo, que dirigia o Externato, entabulou relações cordiais, e um tanto extraliterárias devido à radical prevenção do eminente crítico relativamente ao movimento que a Nestor Vítor empolgara. Residia em casa oficial, ao lado do Ginásio (...). Apesar de ter assumido postura florianista durante a Revolução, foi defensor convicto do governo civilista de Prudente de Moraes (MURICY, In: OC, vol. I, p. XI).

Como se vê, adaptações, acomodações, transformações fizeram-se necessárias no plano da vida material de Nestor Vítor. A coerência buscou-a por meio da defesa intermitente do movimento simbolista e de seus valores, não, sem obviamente, incorrer também em contradições que não se originavam apenas no indivíduo mas na realidade também contraditória de um campo cultural sem plena autonomia, como não poderia deixar de ser o campo literário em relação às esferas econômica e política da sociedade do período.

Sem poder ou querer participar das disputas políticas, embora mais tardiamente assuma o cargo de Deputado pelo Legislativo do Paraná (em 1917), opta por uma separação sistemática entre as questões sociais e as discussões sobre arte e literatura, ao menos até o período de início da Primeira Guerra Mundial. Em parte, porque uma ação militante poderia ser perigosa ${ }^{7}$ nesse final de século e início do próximo; em parte, porque a estética simbolista impunha certo distanciamento do mundo social e, por último, e talvez mais importante, porque os ideais dessa camada social a que pertencia foram derrotados ou superados pela

7 As crises que se seguem à instauração da República $(1889,1891,1893,1897,1904)$ assumem também aspectos bastante violentos, como aponta Sevcenko: "Todas elas foram repontadas por grandes ondas de 'deposições', 'degolas', 'exílios', 'deportações', que atingiram principalmente e em primeiro lugar as elites tradicionais do Império e seu vasto círculo de clientes; mas tendendo em seguida - sobretudo nos seus dois últimos movimentos - a eliminar também da cena política os grupos comprometidos com os anseios populares mais latentes e envolvidos nas correntes mais férvidas do republicanismo" (SEVCENKO, 2003, p. 36-7). 
própria dinâmica da vida econômica e política do país. Um conjunto de fatores que afastou Nestor Vítor das discussões propriamente políticas, mas não o afastou do mundo político e da própria política que existia nas relações literárias do Rio de Janeiro.

Nesse sentido, Andrade Muricy, em seu Panorama do Movimento Simbolista Brasileiro, nega o abstencionismo dos simbolistas, afirmando, ao contrário, uma grande participação da maior parte dos filiados ao movimento e justificando seu aparente isolamento com a própria situação do “desengano” provocado pela República.

\begin{abstract}
Os simbolistas são acusados de se terem abstraído dos interesses coletivos, da vida social. Teriam apenas "sonhado", termo que não disfarça a ideia de "evasão". As respectivas biografias demonstram o contrário, com raras exceções. Quase todos se empenharam apaixonadamente nas campanhas pela Abolição e pela República. Quase todos eram anticlericais e maçons. Essas as preocupações dominantes da época. E foram participantes decididos. O destino da pátria, da raça, da sociedade, encontrou neles observadores, reformadores e apóstolos. Vemo-los fundar clubes e jornais políticos, discursar em praça pública e escrever. Objetar-se-á: - Por que a sua obra literária não reflete expressamente essa preocupação político social? A resposta é fácil. Aquele fervor político abolicionista e republicano ocorreu sobretudo na juventude. Realizado os ideais visados, a Abolição e a República, ficaram com que de mãos vazias. E no que concerne à República, desenganados. (...) Assim, pois, ao definirem-se os ideais que exaltavam estavam superados. Depois, chegou uma fase morna de conformismo, de desilusão apática, apenas percorrida de vagas inquietações, de cor socialista e até anarquistas, e o encontro, afinal, do SuperHomem nietzschiano. É preciso que se lhes faça justiça: os artistas de outras correntes estavam em posição idêntica, no terreno político-social (MURICY, 1973, p. 57).
\end{abstract}

O "fervor" da "hora" surgia aqui e ali mesmo que não travestido de discurso panfletário. O primeiro texto de crítica de Nestor Vítor, escrito em 1896 e publicado em janeiro de 1899, Cruz e Sousa, ligado a esse período, apresenta como nota introdutória alguns parágrafos que valem a pena ser reproduzidos por trazerem explicações aparentemente internas ao universo das letras, mas que apontam para a própria precariedade dos tempos, da vida "mundana" dos intelectuais no momento histórico.

Seria melhor, decerto, em lugar deste esboço, oferecer um estudo complexo e completo, que já abrangesse todas as obras e toda a vida do poeta. Espero fazê-lo um dia; essas páginas, porém, é que já não se podiam fundir, revestindo-se desse outro caráter. Como estão, têm a sua feição própria; alteradas assim, ficariam monstruosas, perderiam o seu maior valor.

Porque este me parece vir do arrebatamento com que os meus vinte e oito anos, que cantam ali, falaram nelas da impressão produzida com a mais extraordinária natureza de artista que até hoje se me revelou na convivência, a alma com que até agora pude voar mais alto nas regiões do espírito, junto à qual mais intimamente pude viver a vida das emoções e das ideias.

Morto Cruz e Sousa, e decorridos mais de dois anos, depois que este trabalho escrevi, - ele transfigurado pela sagração do túmulo, eu sentindo morto, por assim dizer, em mim aquele de que as páginas que se vão ler nasceram (porque os 
acontecimentos e os tempos nos vão dando outro modo de ser) -; pareceu-me que o melhor era religiosamente respeitar a minha obra (OC, vol. I, p. 3).

A decisão de publicar o estudo sobre Cruz e Sousa, mesmo incompleto como afirma, sem dúvida, esteve ligado à decisão de publicar a obra Evocações e, seguida, Faróis do poeta recentemente morto. Mas também esteve ligada à "feição própria" do momento, à "vida das emoções e das ideias" no seu pulsar, na sua existência imediata. Havia uma necessidade "urgente" de expressão da juventude, nos seus "vinte e oito anos", que se torna "monstruosa" à força dos "tempos que nos vão dando outro modo de ser". A força dos escritos nasce do momento, da "hora", em que são produzidos e é essa consciência que Nestor Vítor também quer preservar. $\mathrm{O}$ estudo crítico favorece a recepção das obras literárias, eleva o poeta morto, estabelece relações com uma tradição mais ampla, a europeia e a brasileira, e, embora o "esboço" seja precário, busca se eternizar pela publicação.

Mais do que uma homenagem, o texto Cruz e Sousa é também mais uma defesa do movimento simbolista a que pertencia Nestor Vítor, ainda que o sujeito concreto, histórico, de 1896, não seja o mesmo de 1899. Sua posição no mundo das letras já se alterara, provavelmente em função das relações que estabeleceu com outros autores, nacionais e estrangeiros, e com os críticos consagrados com quem trabalhava no Ginásio Nacional: Sílvio Romero, José Veríssimo e João Ribeiro.

O ano de publicação da monografia Cruz e Sousa foi também aquele em que estabeleceu contato com o escritor Maurice Maeterlinck e em que começou a traduzir a obra deste, La Sagesse et la Destinée. Os horizontes de Nestor Vítor parecem se ampliar para além do restrito mercado das letras do Rio de Janeiro ("os tempos nos vão dando outro modo de ser”). Em 1901, pedirá demissão do Ginásio Nacional e, em 1902, partirá para Paris. A agitação e os conflitos daqueles anos, de alguma forma, provocam movimento no crítico e ele se move em inúmeras direções.

No prefácio de A Hora, escrito em 2 de novembro de 1900, há, por exemplo, uma autoimagem bastante contraditória em relação às suas atividades intelectuais.

Vai para três anos, circunstâncias da minha vida levaram-me a procurar apoio e consolo mais numa existência de gabinete, do que de convivência com os homens, mais de meditação e de contemplatividade do que de ação e de produção literária (OC, vol. I, p. 33). 
Considerando que no período citado (os três anos) trabalhou no Ginásio Nacional, o conceituado Colégio Pedro II, colaborou com o jornal O País, reuniu as obras póstumas de Cruz e Sousa (com a publicação de Evocações e depois Faróis), escreveu os ensaios que formaram o próprio livro que prefacia (incluindo o estudo de fôlego sobre a obra de Ibsen), iniciou a tradução do livro de Maeterlinck, já citado, estudou as obras de Balzac e de Novalis, escreveu estudo introdutório sobre livro de Silveira Neto, Luar de Inverno, escreveu o romance Amigos (publicado em 1900) e preparou o livro de poesia Transfigurações (publicado em 1902), não é possível compreender a natureza de tal "meditação e contemplatividade" com a qual o autor esteve envolvido que fosse superior à "ação" e à "produção literária" que realizou efetivamente.

Nestor Vítor deveria ter em mente a "ação" no sentido da vida social e política da qual deve ter se apartado mais abertamente, e a "produção literária" no sentido estrito da escrita de textos de poesia e prosa próprios. Entretanto, tanto em um quanto em outro dos aspectos, Nestor Vítor deve ter se envolvido com homens da política e com o mundo literário.

Em uma sociedade cujos empregos públicos não cresciam na medida em que se multiplicavam os bacharéis, conforme já indicara Needell, a demissão voluntária do Ginásio Nacional só poderia vir por posições sociais mais ou menos já conquistadas ou garantidas. Nas informações de Muricy, na já citada introdução a Obra Crítica de Nestor Vitor, há interessantes dados sobre as relações que Vítor contrai com o mundo cultural da Europa e como isso reverbera no Brasil.

\footnotetext{
Ainda sensibilizado pela morte de Cruz e Sousa, desempregado, sentindo-se isolado entre os grupos simbolistas que aquela morte deixara sem o seu fulcro catalisador, resolve partir para a Europa, no que foi auxiliado financeiramente pelo seu irmão Francisco Norberto. Em Paris, incumbido pelo Barão do Rio Branco, seu amigo, foi professor dos seus filhos Paulo e Raul. Foi-lhe também conferida modesta colocação no Consulado do Brasil. Escrevia correspondências para o Correio Paulistano e $O$ País, muito mal retribuídas. Realizou algumas traduções e revisões para a Editora Garnier. Em outubro desse ano (1902) aparece o seu único livro de poesia, Transfigurações (Ed. Garnier), que foi louvado por José Veríssimo. Escreveu sobre Canaã, que Graça Aranha ali lhe ofertou, e ainda sobre Bilac, e Garção. Em Paris, além de Maeterlinck, a quem foi levar o primeiro exemplar de sua tradução de $A$ Sabedoria e o Destino, relacionou-se com Maurice Barrès; com o Conde Prozor, tradutor célebre de Ibsen, e que fora Ministro da Noruega no Brasil; Saint-Geordes de Bouhélier; o pintor Carrière, sobre quem escreveu, em 1904, um ensaio; a mulher de Maeterlinck, Georgette Lebranc, e seu irmão Maurice, criador de Arsène Lupin, e outros (MURICY, in: OC, vol. I, p. XIII).
}

Sem dúvida, Nestor Vítor era um homem de letras de trabalho contínuo e disciplinado, sem fortuna que o permitisse apenas a apreciação do mundo das ideias, no entanto soube 
relacionar-se bem com figuras e situações que lhe garantiram a sobrevivência digna mesmo na Paris da belle époque.

É curioso observar, por exemplo, pela informação de Muricy que o rígido crítico José Veríssimo que, mesmo em 1906, quando inicia a considerar a obra do poeta Cruz e Sousa como merecedora de respeito e não somente imitação de Verlaine como dissera na virada do século, já louvara em 1902 a aparição do livro de versos de Nestor Vítor com quem conviveu durante anos no Ginásio Nacional. Indubitavelmente, a "política literária", sobre a qual falarei no próximo capítulo, atuou favoravelmente para a apreciação dos textos do escritor paranaense pelo sério crítico, o "senhor” José Veríssimo.

O próprio fato de viver durante alguns anos na França, que virara moda entre os intelectuais brasileiros na virada do século, deve ter beneficiado a aura de escritor de Nestor Vítor, conforme nos fala Brito Broca em A vida literária no Brasil - 1900: "O chique era mesmo ignorar o Brasil e delirar por Paris, numa atitude afetada e nem sempre inteligente" (BROCA, 1975, p. 92).

Broca chega a citar Nestor Vítor e a situação "estranha” de sua mudança para Paris:

João do Rio, Luís Edmundo, Padre Severiano de Resente, Nestor Vítor, Gilberto Amado, Theo Filho, todos cumprem essa romaria indefectível. Uns voltam logo, com a ideia fixa de uma nova viagem, outros por lá ficam meses e até anos. Nestor Vítor, que se decidira a partir, pela circunstância muito estranha de se achar desempregado, consegue permanecer em Paris longos anos, como professor de português dos filhos do Barão do Rio Branco (BROCA, 1975, p. 93).

Em 1902, entramos já no século XX, quando Nestor Vítor já desenvolvera um percurso de "ação" não tanto no plano propriamente político, mas no plano cultural, e já havia, com a elaboração de textos literários e de crítica, se lançado ao "combate" nas letras, deixando o combate do campo político, porque já se adaptara à situação presente.

Needell chega a afirmar que: "Nesta nova ordem, perderam influência o setor médio urbano e os militares radicais, bem como os setores urbanos em geral" (NEEDELL, 1993, p. 38). Sem a mudança no plano econômico e político, o setor intermediário de que fazia parte Nestor Vítor sai de cena: “Os setores urbanos e médios, em processo de fortalecimento desde as transformações socioeconômicas nos meados do século, haviam sofrido uma amarga derrota" (ibidem, p. 38-9).

Na situação de nosso crítico, a "amarga derrota" pode ser visualizada por ter assumido conscientemente duas tendências isoladas, uma política e outra artística, pois ele "esteve 
ligado a uma estética francamente minoritária - simbolismo - e se filiou a uma corrente política derrotada - jacobinismo (...)" (SILVEIRA, 2010, p. 33).

Não obstante a situação desfavorável em termos gerais, esses primeiros anos de República impregnaram Nestor Vítor de um espírito de luta e de combate pela tendência minoritária a que havia aderido no campo artístico que se mantém, com nuances, por toda a sua produção crítica.

Conhecedor, contudo, das derrotas que sofrera e atuando em terreno adverso foi obrigado a "abroquelar-se", buscando estratégias para furar o cerco e afirmar suas posições, ainda que sob as formas civilizadas e cordiais a que ele sempre gostava de se referir ao falar de sua própria prática como "homem de letras".

É o próprio Vítor que classifica a sua etapa inicial de produção intelectual como de "combate" ao escrever o prefácio para a obra A crítica de ontem, em 1919:

\begin{abstract}
(...) Na primeira parte, sobretudo, é que falo direta ou indiretamente, por modo mais apaixonado, daqueles que se podem incluir nesse rol dos que já se foram, ou dos que já cansaram a meio, ou finalmente dos que se encontram os leitores mais ou menos cansados deles. É por essa razão que desde o prefácio anterior eu não pus dúvida, referindo-me a esse metade do livro, em dizer que há nela algumas opiniões e principalmente muitas expressões que já por aquele tempo, há quatro anos atrás, eu não formularia, ou não formulara sob a forma por que na minha mocidade o fiz. (...) A segunda parte compõe-se de artigos que vim produzindo depois disso, e que melhor correspondiam ao meu estado de espírito no momento em que organizei estas páginas. Já era então bem diverso meu modo de ser do que fora na minha fase de combate propriamente dita (OC, vol. I, p. 255).
\end{abstract}

A divisão do livro A crítica de ontem é feita em duas partes: a primeira corresponde a artigos e estudos realizados e publicados no período que vai de 1898 a 1902; a segunda, é marcada pelos textos do início do século XX até a chegada da Primeira Guerra Mundial. O modo "apaixonado" e "a fase de combate propriamente dita" ligam-se aos anos que se seguem à morte de Cruz e Sousa e correspondem ao início de sua produção crítica.

Nesse sentido, a escrita e a publicação de Cruz e Sousa é a primeira lança na batalha por estabelecer a estética simbolista no universo das letras brasileiras.

Ainda no século XIX, escreve outros estudos e ensaios: “Os Desplantados de Maurice Barrès", escrito em 1898; “O Cyrano de Bergerac", escrito em 1899; e "H. Ibsen”, de 1900, publicados no final de 1900 no livro A Hora.

Embora publicado em livro apenas em 1919, a primeira parte de $A$ crítica de ontem apresenta artigos e estudos escritos e publicados também no final do século. São eles, em ordem cronológica: "Raul Pompéia", de 1898, "As procelárias", de 1899, "Os Novos", de 
1899, “Os Discípulos de Saís e os Fragmentos de Novalis”, de 1899, "H. de Balzac”, de 1899, "Luís Delfino”, de 1899, “Os Sete Ensaios de Emerson”, de 1900, “Um livro de Hello”, de 1900, "F. Niestzsche (Impressões das Pages Choisies)", de 1900 e "O Elogio do Luar do Inverno", de 1900.

Como se vê, a partir de 1898 a chamada vida "meditativa e contemplativa" de Nestor Vítor ganha um ritmo intelectual bastante intenso. Segundo Needell, o ano de 1898 marcará junto ao governo de Campos Sales o início da Belle Époque carioca. O governo ganha a estabilidade política que permitirá dar ares mais modernos e luxuosos aos velhos interesses das elites do país.

(...) O final do século marca a permanente vitalidade, e mesmo o predomínio, de padrões que podem ser percebidos em todo o seu transcurso.

Este fato é crucial para a compreensão da cultura e da sociedade da elite carioca. Todavia, nem no Rio nem no Brasil como um todo, tal continuidade significa ausência de mudança, e sim seu refreamento (NEEDELL, 1993, p. 40).

Se o final dos Oitocentos foram momento de combate mais aberto, tanto no campo político quanto no cultural, o século que se abria trazia as marcas do passado (daí a permanência das elites agrárias no poder e o poder dos parnasianos e naturalistas no mercado das letras), mas também, impulsionado pelas mudanças internas e externas (cujo maior símbolo será a Reforma Pereira Passos no Rio de Janeiro), abrir-se-á espaço, ainda que reduzido, para novos escritores, para os remanescentes do simbolismo e para novas tendências que começam a ser sentidas ou produzidas (como é o caso do sucesso imediato do livro de Graça Aranha, Canaã, que recebe aplausos por todos os lados, como se já representasse o radicalmente "novo" em literatura).

De fato, na homologia que se pode estabelecer entre o meio socioeconômico e o meio cultural e artístico, o simbolismo, ligado em sua origem francesa a certo elitismo, é aqui assumido por uma pequena camada média de intelectuais, alijados do poder político e econômico, que buscará enfrentar as adversidades do meio por associações, grupos, revistas efêmeras, contrapondo-se ao naturalismo e ao parnasianismo, já associados ao gosto das elites letradas.

Permanecerá no mercado das letras o império dos realistas-naturalistas-parnasianos, com a sua Academia Brasileira, que, segundo Candido, no estudo supracitado, "Literatura e Cultura de 1900 a 1945", alcançará o seu apogeu entre 1900 a 1925. Não obstante esse império, o espaço literário também será aberto paulatinamente aos representantes da estética 
finissecular minoritária, com o respeito que adquirem figuras como Emiliano Perneta, Silveira Neto e o próprio Nestor Vítor nesse momento de nossa história cultural.

A percepção de que apenas o "futuro" faria justiça aos simbolistas é insistentemente afirmada nos escritos do crítico aqui estudado. A arte simbolista não poderia ser compreendida pelos contemporâneos, seria uma arte para o futuro, como idealisticamente ele também projetará a realidade de expansão do poder cultural a outras regiões, como o Paraná, no sugestivo título que dá ao seu livro de 1913, A Terra do Futuro. A ideia de que as mudanças ainda poderiam ocorrer permanecia no ar no início do século.

(...) Não há como negar a ocorrência de mudanças no período, mas a persistência de estruturas duradouras, adaptadas a circunstâncias instáveis, talvez seja o dado mais importante.

A própria história da capital ilustra bem o modo como a belle époque significou tanto a continuidade do passado colonial quanto o potencial de mudança do novo período (NEEDELL, 1993, p. 42).

Na verdade, a projeção de futuro e de mudança reabilitadora das injustiças que está na base das convicções primeiras de Nestor Vítor e que aparece com força nos primeiros anos de sua crítica reflete a situação das camadas intermediárias, órfãs das mudanças estruturais que nunca viriam a se concretizar. Pequenas mudanças ocorrerão no início do século XX e algumas delas, inclusive, beneficiarão a crítica de Nestor Vítor e daqueles alinhados a ela. $\mathrm{O}$ novo, contudo, surgirá ainda amalgamado ao velho. Os anos 10 e 20 aumentarão o reconhecimento da crítica de Nestor Vítor no meio cultural, mas esse reconhecimento também diminuirá as "emoções" com que ele se lançara na defesa do simbolismo e dos simbolistas no final do século XIX.

\subsection{Civilização e mundanismo nos primeiros anos do século $X X$}

Se havia uma "fantasia" no clima dos primeiros anos do século XX no Rio de Janeiro era a fantasia "cada vez mais forte de Civilização", conforme nos assevera Needell (2003, p. 209) ao falar da belle époque literária no Rio.

Nestor Vítor, crítico oposto ao mundanismo e ao utilitarismo na vida literária, não poderia participar voluntariosamente dos modismos de época. Com a publicação da monografia Cruz e Sousa (1899) e do livro A hora (1900), o autor conscientemente buscava 
se filiar a uma tradição "místico-simbolista" que em nada, em princípio, compartilharia dos gostos superficiais da elite de então.

A "civilização", aliás, segundo as palavras do crítico, nem poderia ser vista somente por uma perspectiva "materialista", como o acúmulo de bens materiais ou de progressos na ciência e na tecnologia. Já deixara bem claro no texto Cruz e Sousa que esses elementos, no máximo, poderiam ser considerados como parte da civilização: "Todo esse progresso, que é assim que tais cousas se chama, é apenas a metade de uma civilização" (OC, vol. I, p. 13). Faltaria para a realização plena da civilização, a superação do individualismo materialista e a compreensão das esferas mais altas da genialidade que se expressam na Arte, que é, a um só tempo, atemporal e ligada aos requintes de um momento histórico, conforme também afiança ao falar do valor da obra do poeta simbolista:

(...) obra que apesar de tudo, embora contraditoriamente, tem de obedecer a uma filiação inevitável no tempo, e que para ser positivamente uma criação, um produto legítimo da Arte, precisa trazer em si os característicos como traz, da mais requintada, mas, em todo caso da contemporânea civilização (OC, vol. I, p. 23).

Assim, na afirmação do que considera "civilização", termo que, segundo Needell, encherá os corações e mentes da elite e da intelectualidade da belle époque carioca de 1898 a 1914, Nestor Vítor afirmará que ela não é só conquista material do "eu”, mas é também manifestação de um tempo e de um espaço, os quais, segundo o crítico, as terras brasileiras não conquistaram por completo, dado nosso caráter quase virginal frente a história europeia. Por esse prisma, é que julga, por exemplo, a poesia de Luís Delfino, em 1899, reunindo em um só trecho conceituações em torno do país, das suas influências e da civilização aqui nascente e diferente da europeia.

\footnotetext{
Luís Delfino não é apenas um bom poeta; tem a grande lira. Ele já nos dá o êxtase. Às vezes faz-nos a ilusão da própria Natureza a cantar; em sua voz, como nos rapsodos Homero, entreouve-se Pã.

É um Leconte de Lisle tropicalizado, americanizado, abrasileirado, quer dizer monstruoso, - disformado, inferiorizado em muitos pontos, como nós somos inferiores ao francês, - mas, por outros aspectos, mais vasto, mais curioso, mais homem, superior, portanto, pelo cálido destas zonas, pela virgindade desta natureza, pelo tenro desta nossa civilização, pelo ainda incomensurável do nosso horizonte. Ele oferece o flagrante da gestação do nosso gênio: é um pouco caos, é aurora um pouco, é feito de inconsciência em parte, e tem algo daquele alvoroço de quem subitamente se surpreendesse a viver (OC, vol. I, p. 292-3).
}

Ora, na ilusão de se hipercivilizar, o Rio de Janeiro adotará modas, importará costumes, modificará, inclusive, seu espaço urbano por meio da Reforma Pereira Passos. 
Assim, a negação da civilização mundana feita por Nestor Vítor não é, de fato, contraditória com o tipo de civilização que afirmará, porque, segundo o crítico, a nossa ainda é incompleta, disforme. A correspondência com a "verdadeira" civilização coincidirá com o mundanismo também da vida parisiense, embora, nesse momento, o crítico não tenha essa consciência plena expressa em seus escritos.

No ano de 1901, sai a lume a publicação de sua tradução do livro de Maurice Maeterlinck, A Sabedoria e o Destino, com um longo estudo introdutório, com as mesmas diretrizes de seu pensamento já esboçadas nos textos anteriores: apresentação das filiações da corrente "místico-simbolista"; crítica ao mundanismo e ao utilitarismo a partir da crítica aos tempos atuais e ao seu materialismo exacerbado; e a idealização em torno de uma "Arte" atemporal e essencialista.

Em 1902, como já dito, depois de se demitir do Ginásio Nacional, Nestor Vítor parte, com a ajuda financeira do irmão, para Paris: a capital da "civilização" europeia e mundial. Ali encontrará a "civilização" verdadeira. Como veremos, volta com um senso de realidade um tanto alterado. Desse ano, quatro estudos serão depois recolhidos também no livro $A$ Crítica de Ontem. Trata-se de "Canaã, Romance do Sr. Graça Aranha”, "Olavo Bilac”, "José de Alencar e Machado de Assis" e "Correia Garção".

De Paris, será correspondente regular de dois jornais brasileiros, o Correio Paulistano, que terá um longa vida de circulação (1854-1954), e $O$ País, jornal carioca de grande circulação que fora criado em 1884 e tivera como primeiro redator-chefe o ilustre Rui Barbosa, circulando até 1934.

Com os títulos sugestivos de "Cartas de Paris" e "O Mundo, de Paris", os pequenos artigos de Nestor Vítor acabaram por contribuir para o mundanismo do período. As notícias, os comentários, as críticas que tecia estando na capital ocidental da "civilização", Paris, sem dúvida, elevaram o capital simbólico ${ }^{8}$ do crítico.

\footnotetext{
8 Segundo Bourdieu, "todo tipo de capital (econômico, cultural, social) tende (em graus diferentes) a funcionar como capital simbólico (de modo que talvez valesse mais a pena falar, a rigor, em efeitos simbólicos do capital) quando alcança um reconhecimento explícito ou prático (...)" (BOURDIEU, 2001 p. 295-6), de modo que falar de elevação de um "capital simbólico" talvez não seja preciso, no entanto penso na espécie de consagração que representou, no início do século, o conhecimento da cultura francesa, vivida por Vítor durante três anos, colocando-o mesmo que transitoriamente na condição de "homem civilizado". O capital "simbólico" que deriva daí talvez seja significativo para a posição que Vítor adquire no campo literário. Como afirma Bourdieu, "ser conhecido e reconhecido também significa deter o poder de reconhecer, consagrar, dizer, com sucesso, o que merece ser conhecido e reconhecido e, em geral, de dizer o que é, ou melhor, em que consiste o que é (...)" (ibidem, p. 296). O que talvez explique o próprio investimento que Nestor Vítor fará a partir de então ao avaliar obras de escritores brasileiros, mesmo os não alinhados ao simbolismo.
} 
Ainda que fosse o mesmo homem de letras, carregado de princípios de arte antimaterialistas e avesso ainda ao clima mundano do Rio de Janeiro que elevava figuras como Olavo Bilac ou Coelho Neto a seus maiores representes literatos, a "civilização" já havia nele se impregnado. Nestor Vítor era "outro" depois de sua estada na França, como podemos constatar nas palavras espirituosas de João do Rio (Paulo Barreto) em seu $O$ Momento Literário, que fora publicado em fins de 1905, quando o crítico voltava de Paris:

Recebo-o na volta da sua longa viagem. Nestor Vítor está transformado. A violência, aquele ar de pedagogo zangado com que procurava convencer os discípulos, desapareceu. É um cidadão que passou por Paris, que viveu em Paris, que civilizou todas as arestas do temperamento na polidez de Paris.

Três anos antes faria reflexões a propósito do meu inquérito, reflexões onde haveria de certo alguns desaforos, alguns axiomas, algumas ironias e muito talento. No momento em que lhe pedia as suas ideias, entretanto, sorriu. (DO RIO, 1994, p. $105)$.

Exageros à parte de João do Rio, os indivíduos participam de seu tempo, querendo ou não. A oposição mais ou menos aberta aos modismos e a forma como essa oposição se apresenta é que podem e devem variar em temperamentos individuais.

O “mudado" Nestor Vítor, com ares parisienses, usaria, a partir de então, esse capital cultural, adquirido sob o signo do mundanismo da época, para atacar o próprio mundanismo do Rio em curiosos e irônicos artigos, por exemplo na revista Os Anais, do escritor Domingos Olímpio, de que será o responsável pela seção de crítica literária. Registrando a moda das "conferências", importações francesas, escreve sobre as duas conferências de Coelho Neto, “A Água, O Fogo", que haviam sido recentemente publicadas (1906) em opúsculos. Afirma em determinado ponto:

Não se fala dos dilettanti que vestem calças: alguns observei a quem quase lhes caía o queixo, de embevecimento, e com um deles saí que vinha literalmente maravilhado, depois de uma conferência de Olavo Bilac, a quem saiu comparando com Cíceros, Demóstenes e Orfeus. 'Um gigante!' dizia-me o distinto ouvinte, 'um gigante!', resumindo nestas duas palavras todo o seu pensamento de admirador incondicional pelo nosso brilhante contemporâneo.

Foi Medeiros e Albuquerque quem, de uma recente viagem a Paris, trouxe a ideia dessas conferências, por uma que lá ouviu, no Odéon. Olavo Bilac foi quem achou a fórmula vitoriosa: depois que ele falou é que elas começaram a obter na realidade sucesso. (...)

Mas se nós fossemos imitar os parisienses também no programa, a sala do Instituto ficaria quase que inteiramente deserta.

As senhoras, entre nós, não procuram, em geral, ter opiniões senão sobre assuntos chamados "de moças". O mais que um literato pode conseguir delas é enternecê-las ou fazê-las rir com coisas leves e fáceis. Pretender ir além é uma violência à época, uma prova de falta completa de tato e de senso prático. 
(...) Uma das razões do bom êxito que lograram estas conferências está justamente em que se pagava para entrar e sabia-se que boa parte do lucro seria embolsada pelo orador (OC, vol. III, p. 288-9).

Com esse tipo de texto, conseguia passar seus conhecimentos sobre a cultura francesa, mais ainda sobre as práticas culturais do momento, que foram importadas em nossa belle époque, e, ao mesmo tempo, mostrar o caráter superficial e mundano da sua implantação.

Brito Broca ao falar sobre a moda das conferências pronuncia-se muito próximo ao comentário de Nestor Vítor, o que nos faz ver como este captara bem o "espírito" desse hábito cultural:

\begin{abstract}
Mas o êxito do gênero resultou, principalmente, do seu caráter mundano. Tratava-se de uma reunião social, onde as mulheres, geralmente, iam com o espírito com que se vai ao chá-dançante, e os homens acorriam, em parte, para ver as mulheres. Além do que, uma circunstância importantíssima pesava no caso: em Paris se fazia assim, esse era o chique em Paris. (...) Quanto aos escritores, inclinavam-se para o gênero, não somente pelo lucro financeiro, como porque nessa época, em que o sensacionalismo começava a se implantar em nossas letras, e ainda não se dispunha do sistema de propaganda literária de hoje, pronunciar uma conferência constituía um dos melhores meios de dar na vista, de chamar a atenção para a própria pessoa, fazer o próprio reclame, enfim.

Segundo Medeiros e Albuquerque, Bilac foi o mais popular dos intérpretes desse curioso espetáculo mundano (BROCA, 1975, p. 140).
\end{abstract}

Se já no século XIX o conhecimento da cultura francesa era significado de prestígio", no auge da francofilia da belle époque, esse conhecimento assumiria ares quase divinos. Nestor Vítor que era um crítico mordaz ao mundanismo dos salões, contraditoriamente assume que também chegara a realizar conferências com "algum sucesso". Em 1915, em uma conferência sobre três escritores do nordeste brasileiro, publicada em 1916, Três romancistas do Norte, afirma a determinado ponto:

\begin{abstract}
As visitas que o literato faz aos salões lhe são generosamente pagas pelas cheias à cunha que vários deles obtém da nata social feminina e masculina, quando realizam suas conferências ou seus mais complexos festivais artísticos-literários. Até quem vos fala, apesar de tão pouco mundano e tão canhestro, já os realizou, e pode envaidecidamente dizer que com bom êxito (OC, vol. I, p. 170).
\end{abstract}

Entre essa afirmação publicada em 1916 e o artigo sobre as conferências de Olavo Bilac e Coelho Neto, há um intervalo de dez anos, em torno dos quais, com certeza, Nestor

9 “(...) Como vimos, a educação recebida pelos membros da elite era clássica, com grande ênfase literária. Conhecer a literatura, sobretudo a francesa, era a marca de um indivíduo bem-educado. Portanto, a familiaridade com as letras, os versos adolescentes e um respeito permanente pelos literatos eram comuns naqueles que pertenciam, ou aspiravam, à elite carioca" (NEEDELL, 1993, p. 211). 
Vítor mudou seus ares mais do que já sentira João do Rio em sua entrevista em fins de 1905. Sinal também de que o clima cultural e político do período penetraria no espírito do crítico e acabaria por moldar também suas práticas e seu discurso. Não direi, todavia, que se trata de pura capitulação, mas das próprias vicissitudes de um campo cultural em constante transformação e sem autonomia suficiente para permitir a internalização de certas regras em seus participantes. Escrever em jornais, realizar conferências, como ele ainda afirma nesse texto, é parte do "ganhã-pão" do homem de letras brasileiro da época, destinado a ser polígrafo.

Retornando ao período em que volta ao Brasil, vemos que, de 1906 em diante, a produção crítica de Nestor Vítor incide sobre autores de tendências literárias mais variadas do que no período anterior. Temos também uma variedade maior nas formas de seus textos, desde artigos curtos que se multiplicam até o final de sua carreira a alguns poucos ensaios, como o que dedica a Alberto de Oliveira, os quais lembram os seus primeiros textos críticos.

A partir de 1906, volta a lecionar no Colégio Pedro II e também na Escola Normal, mantendo a seção de crítica na revista Os Anais. Para Silveira, o ano de 1906 também marca a "perda na força do pensamento simbolista" (SILVEIRA, 2010, p. 95) e a apreciação mais sistemática por parte de Vítor das produções brasileiras, porque sente que o momento é de maior hibridismo nas formas literárias. Surge a percepção de que as "escolas literárias" haviam passado e se diluíam formando novos resultados, como o que ele elogiara no artigo de 1902 sobre Canaã de Graça Aranha.

(...) É somente após seu retorno, em 1906, que essa busca de uma mescla se torna mais clara, mesmo que ela já estivesse presente na fase final do seu momento francês, quando, por exemplo, elogia a produção de Alberto de Oliveira.

Observadas as críticas ferozes a escritores parnasianos, naturalistas e realistas feitas até esse momento, percebe-se agora um apaziguamento das disputas entre os grupos literários no Brasil. (...) Essa mistura de tendências veio, na verdade, a consolidar uma prática já comum no Brasil, que sempre teve as fronteiras entre as tendências literárias muito fluidas, com autores participando, muitas vezes de dois ou mais movimentos, alguns até mesmo antagônicos em sua essência, ao mesmo tempo (SILVEIRA, 2010, p. 97).

A pureza e a "Religião da Arte" que tanto defendera Nestor Vítor anos antes e que continuará, de alguma forma, ainda defendendo quando se dirigirá aos novos escritores, aparece objetivamente impossibilitada pelo contexto histórico e cultural do país e pela própria abstração idealista que representa tal concepção de arte, feita apenas de intenções. Ao final, Nestor Vítor teria de ceder voluntária ou involuntariamente ao universo restrito de nossas 
letras, comentando, discutindo e analisando obras também dos naturalistas e dos parnasianos e de seus epígonos para se consolidar como crítico literário no período vivido.

Com efeito, lúcida e desoladora é a afirmação que Nestor Vítor faz, por exemplo, em 1906 sobre as disputas no campo das letras nacionais diante de um universo de "novidades" vinculadas à belle époque, que acabava por diminuir o valor e o impacto dessas disputas.

(...) Hoje ninguém briga por causa de teorias e de escolas, porque 'não vale a pena'. Todos criaram juízo a um tempo, ganharam a triste sabedoria negativa dos anulados. Andamos juntos menos pela alegria de um vitorioso pensar comum do que pela tristeza de uma tácita ou confessada queixa geral. Se o ambiente é estranho à nossa existência, se não se nos julga, somos todos do mesmo jaez.

Veja-se, por exemplo, este livro, Os Emancipados, de Fábio Luz, em que ele defende o amor livre, a abolição da propriedade, a extinção da moeda como meio de relação, a anulação do direito de julgar, tal e qual os mais radicais ideólogos conhecidos o fazem. Suscitou ele, porventura, já não digo qualquer escândalo, mas discussões de certo modo calorosos, sérias análises das páginas em que semelhantes ideias são expostas?

Foi quase como se nesse romance se dissessem as mesmas inocuidades mais ou menos brilhantes, as únicas coisas, sistematicamente, que se dizem nas conferências literárias do Instituto de Música, as quais constituem uma outra novidade da época. No fundo, conferencistas, positivistas, anarquistas, nietzschenianos, neocristãos, clássicos, gramáticos liberais... tutti quanti, são julgados hoje em dia entre nós igualmente inócuos, porque afinal não ameaçam derrubar o que quer que seja que no momento se tome a peito (OC, vol. I, p. 402)

Quando a crítica literária cedia ao jornalismo de propaganda de livros e de seus autores, quando os salões e as conferências igualavam todos os gostos a um mesmo prazer passageiro e "mundano", os literatos recolhiam-se cada vez mais à sua insignificância geral no mundo "materialista" e burguês. Era a consciência dos impactos da belle époque tanto carioca quanto parisiense que Nestor Vítor havia vivido que o fazia agora refletir sobre o significado da literatura no mundo social e, de alguma forma, começar a transigir com seus princípios de outrora. O que, por um lado, significava perda da intensidade e combatividade de sua crítica; por outro, indicava maior possibilidade de consolidação da mesma em o nosso restrito meio intelectual: "O seu retorno da Europa lhe abre várias portas para a publicação de suas críticas, sendo que o ano de 1906 é frutífero em quantidade de artigos" (SILVEIRA, 2010, p. 98).

Desse modo, ainda em 1906, escreve intensamente estudos e artigos sobre diversos escritores contemporâneos, reunidos na segunda parte do livro A crítica de ontem. São eles: "Alberto de Oliveira", "Treva por Coelho Neto", "Relíquias da Casa Velha por Machado de Assis", “As Religiões do Rio por João do Rio (Paulo Barreto)", "Livro das damas e donzelas por D. Júlia Lopes de Almeida", “Outros Estudos de Literatura Contemporânea por Sílvio 
Romero", "Histórias do Meu Casal por Mário Pederneiras”, “Os emancipados por Fábio Luz", "Evangelho de moço por Correia de Araújo". No mesmo livro, aparecem os estudos "Eugene Carrière", "O Ateneu" e "Rúben Dario", referindo-se a artistas do passado. Ainda encontramos, do ano de 1906, outros artigos reunidos no volume 3 da Obra Crítica de Nestor Vitor, que correspondem a textos não selecionados pelo próprio autor para publicação em formato de livro, mas aos quais já tenho me referido, como o artigo sobre as conferências literárias no Rio, citado acima. No volume 3, de 1906, encontramos, então, "Rocha Pombo, Historiador", o "Alemanismo no Brasil por Sílvio Romero" e um artigo dividido em três partes: "A Água, O Fogo", "Cantos e Contos" e "Frases e Palavras".

Esse conjunto de artigos e estudos podem apresentar pouco interesse hoje em dia, não só pelo distanciamento temporal mas, como disse no início, pela pouca relevância que a maioria dos autores estudados tiveram na formação do sistema literário brasileiro a partir do advento do modernismo.

Sem negar essa realidade, tenho que argumentar que o aumento na produção crítica de Nestor Vítor ganha em quantidade refletindo os próprios padrões da vida material do começo do século. Mais de uma vez, Nestor Vítor afirmou que chegavam cada vez mais livros para que ele avaliasse e emitisse seus comentários críticos. A omissão do estudo das obras literárias e críticas desse período (com a exceção de autores hoje consagrados, como Lima Barreto) é parte também da representação que ficou em nosso imaginário do contexto histórico anterior aos modernistas: "Herdeiros do modernismo, leitores e críticos recentes normalmente aceitam a condenação modernista do fin-de-siècle brasileiro como um período afetado e superficial, apesar de alguns registrarem, ocasionalmente, sua importância antecipatória" (NEEDELL, 1993, p. 215).

A consciência crítica, no entanto, que também começa a surgir nesse período com força em razão da quantidade maior de escritores é algo a que também vai se referir Nestor Vítor. Para ele, os escritores do período são obrigados a serem também críticos e não será estranho, a partir dos anos de 1910, que muitos escritores de prosa e poesia também enveredem sistematicamente pela crítica literária ou social, a exemplo de Ronald de Carvalho ou Tasso da Silveira.

Entrando nos anos seguintes, vemos, porém, que a produção recolhida em livro é menor do que fora antes. Alguns fatores de ordem pessoal e social devem explicar essa situação. 
Apesar da abundância de escritores e a ampliação do jornalismo que solicitava maior participação dos intelectuais do período, os referenciais literários e críticos de Nestor Vítor estavam se esgotando nesse momento. Segundo Silveira, os anos que antecedem a Primeira Guerra e conformam a belle époque carioca são de desagrado para o tipo de crítica que Nestor Vítor até então praticara:

Como resultado desse esgotamento gerado pela padronização, por essa difusão de posturas pré-definidas de como ser um decadente, parte da vida literária brasileira a assume para si, incorporando valores provenientes tanto do simbolismo francês, como do dandismo inglês. (...) Em relação a Nestor Vítor, essas mudanças geram desagrado, pois levam a literatura mais para a prática social de bares e cafés, retirando a força de isolamento e do recato sempre defendidos pelo crítico paranaense (SILVEIRA, 2010, p. 96).

A arte elevada, "pura", que defendera nos anos anteriores, também se imiscuía na padronização de gostos da belle époque. Ainda que minoritária, a arte simbolista esterilizavase em atitudes mais ou menos convencionais como afirmaria explicitamente no texto "Farias Brito", publicado em 1917.

\begin{abstract}
Por isso dentro em pouco chegavam ao limite da sua real capacidade inovadora, começando daí por diante a executar mal disfarçados ritornelos ou mais ou menos hábeis rapsódias epígonas. Por fim, foi o Simbolismo diluindo-se transigindo com o Parnasianismo e o Realismo, até com o defunto Romantismo, e o próprio classicismo arcaico, como estes com ele, na estética e até na ética própria a cada uma destas escolas, até que caiu na tolerância quase absoluta que era moda quando começou a Grande Guerra (OC, vol. I, p. 238).
\end{abstract}

Amadurecia-se, portanto, nesses primeiros anos do século XX, uma consciência do fim da fase "heroica" dos missionários da nova arte. Sendo uma fase de transição, há ainda até 1914 a defesa dos valores elevados da arte simbolista e a defesa de escritores vinculados a essa estética. Entretanto, de forma contraditória, a arte "pura", que deveria estar ligada às "formas", começa a ser avaliada também em relação à sua "função" ${ }^{10}$ na história brasileira.

10 Penso aqui na oposição entre "forma" e "função" que Pierre Bourdieu apresenta entre a apreensão da arte pelos intelectuais e pelos "homens comuns". Segundo Bourdieu, "os intelectuais acreditam mais na representação - literatura, teatro, pintura - que nas coisas representadas, ao passo que o 'povo' exige, antes de tudo, que as representações e as convenções que as regulam lhes permitam acreditar 'naïvement' nas coisas representadas" (BORDIEU, 2017, p. 12-3). O que significa que, para os defensores da arte "pura", há um primado conferido à forma, enquanto para o "restante" dos "homens comuns", o primado é dado à função. Na crítica literária brasileira do século XIX, a função da literatura viria em primeiro plano. A tentativa de Nestor Vítor, aparente nos seus textos críticos iniciais, é dar um primado à forma, à maneira de criação, embora, como sabemos, sem as condições históricas prévias para que isso ocorresse de fato tanto na sua crítica, amalgamada ainda a certos pressupostos deterministas do meio e do momento, quanto na produção por ele avaliada. 
É uma maneira híbrida de crítica, em que os pressupostos da arte "pura", voltada para a esfera propriamente estética, misturam-se aos problemas do tempo e da história, no caso, a tradição brasileira e seus valores supostamente originais, "legítimos". Mas isso se tornará mais claro, mais bem definido no período posterior a 1914. De 1907 a 1914, em que a produção crítica coligida em livros escasseia, o que se manifesta é esse clima de desolação pelo empobrecimento da qualidade dos textos literários em contraste com a elevação da "vida literária" mundana.

A esse respeito, podemos citar dois extratos que confirmam a consciência de um contexto "espiritual" mais pobre, o que deve significar de um modo mais geral, na verdade, a transição para um modelo de urbanização importada de países como a França ou os Estados Unidos (que ganhava cada vez mais destaque internacional) e que retirava das gerações mais antigas um sistema de valores anteriormente conhecidos e defendidos.

\begin{abstract}
A impressão que os críticos da cultura transmitem pela imprensa, a respeito do período, era de se estar atravessando uma profunda crise intelectual e moral, marcada pela mais atroz decadência cultural. Em tom acrimoso e pessimista, falavase de 'vazio de ideias' e 'fim de uma tradição'. Eram referências à vitória do novo espírito, 'agitado e trêfego', que tomou conta da cidade, arrebatada pelo novo cenário que a Renegeração lhes descortinara (SEVCENKO, 2003, p. 120).
\end{abstract}

Essa consciência de "crise intelectual e moral" não se coaduna perfeitamente com os novos espaços de atuação do homem de letras nos primeiros anos do século XX segundo ainda Sevcenko, para quem se abriam "novas oportunidades, até então imprevistas para esse grupo" (ibidem, p. 117), como a expansão de um "novo jornalismo", que era consumido amplamente pelas "camadas alfabetizadas da cidade" (ibidem, p. 119).

O que era certo e é a tese geral que aparece no conhecido livro de Brito Broca, $A$ vida literária no Brasil - 1900, é de que a "vida literária" sobrepujava a própria criação literária do período, criando, para uma parcela dos homens de letras, essa impressão de empobrecimento geral.

Essa febre de mundanismo que o Rio começa a viver, reflete-se nas relações literárias. As seções mundanas dos jornais ocupam-se, ao mesmo tempo, de literatura. Figueiredo Pimentel, autor do célebre slogan 'O Rio civiliza-se', na discutidíssima coluna do 'Binóculo' na Gazeta de Notícias - cujas edições dominicais, com páginas coloridas, eram magníficas -, faz comentários sobre o último baile, a última recepção, entrelaçando-se com a notícia de uma conferência ou de um livro de versos. (...)

O velho bibliófilo Martins costumava dizer a Capistrano de Abreu que o gosto pela leitura, no Rio, havia desaparecido de $1870 \mathrm{em}$ diante, com as corridas de cavalos. Que conclusões tiraria esse remanescente da idade de ouro do Império, ao ver, na 
década de 1900, a literatura de braços dados com aquilo que sempre fora considerado a sua pior inimiga: a vida mundana? (BROCA, 1975, p. 4-5).

Assim, tanto o extrato de Sevcenko quanto o de Broca evidenciam que as mudanças impostas pela belle époque carioca deveriam se refletir nas consciências desses sujeitos não apenas como exaltação dos novos tempos, como aparece nos textos de João do Rio, mas como percepção de "empobrecimento" cultural para aqueles homens já formados no século anterior.

Isso explicaria, em parte, a "baixa quantidade de textos" de Nestor Vítor em "uma época de baixa qualidade de produção" do "próprio contexto literário" (SILVEIRA, 2010, p. 104). Suponho, no entanto, que apenas "em parte" isso se explique por razões estritamente culturais, porque evidentemente a vida intelectual do crítico nunca esteve somente ligada à atividade crítica propriamente dita.

Sabemos que ele atuou desde muito cedo como professor, retomando o magistério assim que retornou de Paris. Do mesmo modo, suas relações sociais não se restringiam às relações do mundo dos literatos. Conforme afirmei na seção anterior, houve atuação política de Nestor Vítor no século XIX e de alguma forma continuaria a existir no século XX, como demonstram a sua participação como representante do Paraná, em 1908, na "Convenção Nacional que escolheu Rui Barbosa para candidato da oposição" (VIVEKANANDA, 1973, p. 115), bem como a participação em 1914 na fundação da Liga Brasileira pelos Aliados, cuja presidência era exercida por Rui Barbosa e da qual foi secretário e, por último, a sua eleição como “deputado ao Congresso Legislativo do Paraná” em 1918 (ibidem, p. 115).

Se os anos de 1906 a 1914 são os anos de "consolidação do espaço crítico de Nestor Vítor", como defende Silveira em sua Tese, é natural que, para essa consolidação, ele também estivesse envolvido em outras relações mais amplas que a pura contemplação das obras literárias em um período em que a "vida literária" era mais relevante do que a literatura em si e as questões econômicas e políticas exigissem cada vez mais algum posicionamento dos intelectuais conforme se aproximavam da Grande Guerra.

Interessante lembrar aqui o que foi dito antes: a saída de Nestor Vítor do Brasil para viver alguns anos em Paris foi possibilitada por sua demissão voluntária do Ginásio Nacional, pela ajuda financeira do irmão e por sua relação com os detentores do poder político: “em Paris, incumbido pelo Barão do Rio Branco, seu amigo, foi professor dos seus filhos Paulo e Raul. Foi-lhe também conferida modesta colocação no Consulado do Brasil. Escrevia 
correspondências para o Correio Paulistano e O País, muito mal retribuídas." (MURICY, in: OC, vol. I, p. XIII).

Ou seja, nunca estiveram rompidos seus laços com o mundo político e social da Primeira República. Se a marca do período foi o crescimento da influência do jornalismo e, em relação a este, Nestor Vítor continuara mantendo vínculos até fora do país, e se o contexto foi favorável a muitos intelectuais que atuaram para "consolidar a imagem austera de uma sociedade ilustre e elevada, merecedora da atenção e do crédito europeu incondicional" (SEVCENKO, 2003, p. 118), vemos que o nosso crítico também manteve relações com os poderes instituídos nesse período por meio do Barão do Rio Branco, "que procurou lotar as dependências do Itamaraty, e mesmo de setores paralelos da administração, de intelectuais respeitáveis, ou de quem afetasse uma tal moldura" (ibidem, p. 118).

A participação na Convenção que escolheu Rui Barbosa como candidato à presidência também demonstra que, ainda que quisesse separar a preocupação política das preocupações estéticas, mantinha, quando possível, a participação política ativa.

Particularmente, o fim dos anos de 1910 tornou possível essa participação, tanto de Vítor quanto de outros intelectuais dos setores intermediários conforme nos indica Boris Fausto em História Concisa do Brasil.

\begin{abstract}
Rui procurou atrair o voto da classe média urbana, defendendo os princípios democráticos e o voto secreto. Deu à campanha um tom de reação contra a intervenção do Exército na política. Atacou os chefes militares e contrapôs a Força Pública estadual ao Exército como modelo a ser seguido. Embora a base política mais importante de Rui Barbosa fosse naquela altura a oligarquia de São Paulo, sua campanha se apresentou como a luta da inteligência pelas liberdades públicas, pela cultura, pelas tradições liberais, contra o Brasil inculto, oligárquico e autoritário. A vitória de Hermes produziu grandes desilusões na restrita intelectualidade da época. (FAUSTO, 2001, 154).
\end{abstract}

Vemos que, como parte da "classe média urbana", Nestor Vítor vislumbrou a possibilidade de uma mudança nos rumos da República com o engajamento nas eleições presidenciais. Como outras vezes, a sua posição política foi derrotada historicamente.

Assim, os fatores de "escassez" na produção crítica de Nestor Vítor no período compreendido entre 1907 a 1914 talvez ganhe sentido no interior de fatores sociais e pessoais mais amplos do que apenas uma mudança de perspectiva interna ao movimento das letras, embora estas, sem dúvida, tenham sido um fator, como já apontado, para essa situação.

Os textos escritos e publicados nesse período são: “Contos e Pontos de Rocha Pombo", "Horto, Poesias de Auta de Sousa" e "Emiliano Perneta"; os três de 1911, reunidos 
no livro A crítica de ontem, publicado em 1919. Antes desses textos, Nestor Vítor teria escrito duas cartas, uma de fevereiro de 1909 e outra de abril de 1911, reunidas no livro Cartas à gente nova, publicado em 1924. A primeira chama-se "Sangue" e trata do livro de poemas de Da Costa e Silva, e a segunda "Os Inconfidentes", sobre do texto dramático de Goulart de Andrade.

Em 1912, aparece um artigo sobre o livro de Gustavo Barroso, "Terra do Sol", não reunido pelo crítico em nenhum livro, mas publicado no terceiro volume da Obra Crítica de Nestor Vítor, e o artigo "A Academia anarquizada", reunido em A crítica de ontem.

Do ano de 1913, temos em livro "A festa a Coelho Neto" e "Hermes Fontes", ambos reunidos também em $A$ crítica de ontem e um artigo, também não coligido em livro, mas publicado no volume 3 da Obra Crítica, "A América do Sul julgada por um Inglês".

Fechando esse período, temos o ano de 1914, que, segundo Needell, corresponderia ao ano final da belle époque carioca, mas, conforme Broca, seria apenas o ano de susto da intelectualidade com a Guerra que avançava sobre a França, não encerrando a "onda de futilidade, de prazeres, de inebriamento" que "continuava a envolver o ambiente carioca" e que se estenderia "pelo menos até 1916" (BROCA, 1975, p. 269).

Assim, em 1914, há um artigo sobre peça de Emiliano Perneta, "Pena de Talião" e um resgaste da memória de Cruz e Sousa com o artigo "O Poeta Negro", ambos reunidos em $A$ Crítica de Ontem.

Resumindo esse período, Silveira apresenta uma conclusão com a qual concordamos e que vale a pena ser transcrita. Afirma o estudioso:

\begin{abstract}
Mesmo com uma maior valorização do passado, nem todo o passado da literatura brasileira é valorizado na sua crítica. As estéticas com fundamentação cientificista, como o naturalismo, e na objetividade, como o parnasianismo, mesmo sofrendo ataques com menor intensidade, ainda serão desmerecidas, em especial pela valorização de uma corrente que começa a ganhar força nesse período: o neocristianismo. Ainda que Nestor Vítor não venha a ser um cristão, o que nunca se tornará plenamente, a valorização da transcendência e da elevação espiritual, nunca se esquecendo do caráter moralizador desta tendência (tão ao agrado da sua postura crítica), o fazem aproximar desta corrente, ainda mais que ela aparenta trazer suas raízes de dentro da produção simbolista (SILVEIRA, 2010, p. 110).
\end{abstract}

$\mathrm{Na}$ descrição geral que faz o estudioso da obra de Nestor Vítor, a conclusão é correta se olharmos em conjunto os estudos e os artigos conhecidos do crítico. O que buscarei salientar, no entanto, quando apresentar a análise de alguns desses textos e desse conjunto, serão as disputas no campo cultural das letras e como a sua crítica que então se consolida no 
panorama intelectual da época acaba por fazer concessões a ideias e "tradições" que, no período anterior, ele repugnava como contrárias à arte elevada e heroica que defendia.

O discurso em torno do essencialismo da arte e de sua pureza confrontou-se com as condições objetivas de criação e fruição da arte no começo do século, evidenciando transformações que dariam no período pós-guerra contornos a uma crítica cada vez mais conservadora e nacionalista.

\subsection{Nacionalismo e espiritualismo nas manifestações culturais a partir da Guerra}

Segundo Silveira (2010), o desmoronar da crença cientificista, com o advento da guerra de 1914, não consagrou, em contrapartida, o pensamento subjetivo, místico, que Nestor Vítor defendera no início de sua produção intelectual, porque tal pensamento trazia também em sua origem a defesa de certo cosmopolitismo e de certa integração mundial que a Primeira Guerra destruiu. O mundo civilizado de que a estética simbolista teria sido um reflexo parecia ruir com o avanço da guerra. A esperança de um "futuro" glorioso para a estética finissecular deixa de existir.

Em termos de projeto estético, não era só a busca de "recriação do modelo original (...), mas a própria fragmentação da estrutura teórica sobre a qual se assentava o pensamento simbolista" (SILVEIRA, 2010, 112) que obrigaria mudanças no pensamento crítico de Nestor Vítor. Ele não via apenas o enfraquecimento das inovações simbolistas, mas, com clareza, o "erro" de posições que adotara no período anterior à Guerra. O ideal da "Religião da Arte" é concebido agora mais como um arroubo da juventude do que propriamente um ideal a ser alcançado no futuro.

Consciente das mudanças desse primeiro quartel do século XX, Nestor Vítor buscará, na verdade, os representantes desse novo momento, dessa nova "hora". Ainda que, nesta busca, esteja munido com as armas críticas e os referenciais teóricos do passado: aparecerá com força, nesses escritos de 1915 a 1930, a valorização do ideário romântico, que já era ressuscitado nas críticas elogiosas a certos poetas em 1911.

O que o ideário romântico nacional trazia, no entanto, não era, por exemplo, só certa feição sentimental e subjetiva, que ele exaltará em poemas de Emiliano Perneta e Auta de Sousa, mas, sobretudo, o caráter religioso e nacionalista que o romantismo adquiriu em nossas terras. 
Segundo Antonio Candido, em Formação da Literatura Brasileira, "todos os românticos, com poucas exceções, manifestam um ou outro avatar do sentimento religioso, desde a devoção caracterizada até um vago espiritualismo quase panteísta" (CANDIDO, 2000, p. 17). Ainda conforme Candido, “o espiritualismo era um pressuposto da escola, e todos pagavam o seu tributo" (ibidem, p. 17).

Na leitura que Silveira realiza sobre a obra crítica de Nestor Vítor, há a análise de que a religiosidade assumiria maior importância nesse período, não tanto por uma "abrupta conversão religiosa na sua vida pessoal", mas por suas "tendências de exploração subjetivas da realidade, manifestadas desde os tempos do simbolismo", encontrando "eco contemporâneo ao lado de jovens escritores, ligados às práticas litúrgicas católicas (...)” (SILVEIRA, 2010, p. 131).

Há, contudo, mais do que "tendências subjetivas", claramente descritas em seus textos, uma resposta moral a uma situação histórica que permitia a convergência de posições do escritor com os grupos espiritualistas, católicos e nacionalistas do período. Como afirmarei mais abaixo, a posição moralista correspondia a certa postura das classes médias urbanas ${ }^{11}$ na tentativa de "sanear" moralmente o país, afetado por uma República oligárquica e atrasada frente aos novos dilemas mundiais postos pela Guerra e pela Revolução Russa.

Embora Nestor Vítor não integre oficialmente o grupo dos nacionalistas que formariam a chamada "falsa vanguarda" de que fala Antonio Arnoni Prado em 1922 Itinerário de Uma Falsa Vanguarda e o tom de seus textos nunca chegue à exaltação da força e da necessidade da superação do atraso por meio de uma ação política autoritária, como aparece nos textos dos autores analisados por Prado, a sua crítica elogiosa aos espiritualistas e ou a autores do grupo dos "verde-amarelistas", no que tange à sua linguagem em confronto com os "andradistas", acaba por legitimar um discurso que o próprio Nestor Vítor chega a reconhecer em 1928 como "passadistamente patriota"12.

11 Sobre a composição da classe média na Primeira República, ver o estudo de Paulo Sérgio Pinheiro "Classes Médias Urbanas: Formação, Natureza, Intervenção na vida política" in: História Geral da Civilização Brasileira. O Brasil Republicano. Tomo III. Volume 2, p. 8-37, no qual o autor, em linhas gerais, além de apresentar a possível formação e natureza das classes médias (formadas por elementos de modos de produção pré-capitalistas e por estratos urbanos ligados já à esfera de circulação do capital e por "aqueles que contribuem para a realização da mais-valia"), busca também desenvolver a tese de que as "classes médias na Primeira República jamais tiveram um desempenho que visasse diretamente o aumento de seu poder no sistema político brasileiro e jamais foram capazes de promover transformações que pusessem em risco a pauta de dominação vigente" (PINHEIRO, 1978, p. 36), de modo que o papel reformista e até conservador, em certos aspectos, que Vítor assume a partir de então não destoa "da dependência ao nível ideológico" que as classes médias urbanas tiveram no período da Primeira República.

12 Embora Nestor Vítor não se debruce atentamente aos "verde-amarelistas" como faz em relação aos espiritualistas ou "andradistas" (Oswald e Mário de Andrade), registra, em 1928, em um artigo sobre 
A questão é que mais do que aderir aos grupos dos jovens aos quais ele estará bastante atento, como demonstram os textos que escreveu sobre Mário de Andrade, José Américo de Almeida, Manuel Bandeira, Menotti del Picchia, Ronald de Carvalho, Gilka Machado, Plínio Salgado, Jorge de Lima, Cassiano Ricardo e outros hoje já esquecidos, o papel de Nestor Vítor acabava endossando, enquanto um crítico já reconhecido, certa reação conservadora que se enformava no período.

Pelas próprias escolhas que faz, como o rememorar contínuo da obra de Farias Brito, cujo sentido social seria mais conscientemente utilizado pelos "dissidentes" da Semana de Arte Moderna, acaba por reconhecer e validar os escritores que conformariam a reação católica e o movimento integralista, ainda que ele não tome parte nem de um nem de outro. Mais uma vez, como acontecera quando retornou de Paris com seu capital simbólico de "civilizado", Nestor Vítor contribuiria para um movimento da vida cultural que, a princípio, não corresponderia com as concepções mais "puristas" que ele defendera em relação à arte no começo de sua produção.

Por essa perspectiva, o seu repúdio ao "materialismo da época" torna-o também susceptível à difusão do pensamento autoritário "dos grupos que sustentavam a necessidade de definir o Estado nacional: (...) em fazer a propaganda do Brasil dentro do Brasil, em estreitar a federação política e espiritual, divulgando estrategicamente a 'obra humanista' de Farias Brito" (PRADO, 1983, p. 25).

Se os objetivos e a visão política de Nestor Vítor não coincidiam plenamente com um Oliveira Viana, um Alberto Torres ou um Jackson de Figueiredo, como podemos ver nas cartas reunidas no livro Cartas à Gente Nova, de 1924, o fato de difundir a obra desses autores, utilizando-se de uma crítica que Silveira chama de "simpática", acabava por atuar positivamente; legitimando, no período, as aspirações autoritárias e conservadoras desses grupos que ganhavam espaço na vida política e cultural da Primeira República.

Não é de estranhar, por exemplo, que, mesmo sem aderir à renovação católica, já que o crítico se afirma como um adepto da "religião" que ainda há de vir, o último livro de textos publicados ainda em vida de Nestor Vítor, Cartas à Gente Nova, inicie-se com o prefácio de Jackson de Figueiredo, o líder da reação católica, e termine com a análise do livro A Igreja

Cassiano Ricardo e Wellington Brandão, intitulado "Todos Românticos...” o elogio aos "verde-amarelistas", que "representam uma das ramificações do vanguardismo paulista, na hora atual. Sua bandeira por si mesma se define. Uma vez solta ao vento, não é preciso dizer-se que ela corresponde a um intuito nitidamente, enfaticamente nacionalista" (OC, vol. II, p. 409). 
Silenciosa, de Tasso da Silveira, um dos fundadores da Revista Festa, órgão da ala espiritualista do modernismo.

Apenas para ilustrar o meio intelectual que Nestor Vítor acaba, dada as opções em jogo, assimilando um tanto involuntariamente, quero citar aqui um parágrafo de Jackson de Figueiredo no prefácio de Cartas à Gente Nova:

\begin{abstract}
Mas voltemos à nossa distinção primitiva: creio que precisamos mais de pensadores do que de escritores, precisamos de homens que, pela força do espírito, façam nascer grandes correntes de aspirações, transplantem ideais enobrecedores, com que, pouco a pouco, se vá modelando a nossa personalidade ainda mal esboçada, ante as já completas, que constituem o escol do planeta (FIGUEIREDO, in: OC, vol. II, p. 64)
\end{abstract}

$\mathrm{O}$ que Figueiredo defende e serve de prefácio à crítica de Nestor Vítor, a qual se pretendeu "estética", é valorizar mais a moral do que a estética propriamente: "precisamos de mais pensadores do que escritores". Tão longe se nos afigura essa postura daquela defendida nos textos iniciais de crítica de Vítor, quando apontava o papel "apostólico", de vidente, de vate, dos grandes poetas, dos artistas-chave, quando apontava o isolamento, em atitude biografista, de Ibsen, para alcançar o melhor de sua produção artística.

Com efeito, o crítico Nestor Vítor que buscou separar, no final do século XIX, a arte das demais esferas da vida social, revelou, em sua prática, nas condições existentes da Primeira República, a impossibilidade desse projeto. A "função" da literatura reaparece novamente como indissociável da "forma" em que ela se apresenta, o que já na década de 1920 confirma o percurso que ele vinha fazendo desde o retorno de Paris.

Mais uma vez, a sua obra tinge-se das cores do momento, da "hora", refletindo, também mais uma vez, certos temores que deveriam brotar da condição dos setores intermediários da sociedade brasileira, o que explica a análise que faz dos movimentos comunista e fascista, igualando-os sob certa perspectiva finalista da história, e deve ajudar a explicar a idealização que constrói em torno de "nosso" nacionalismo, "longe" desses radicalismos. É o que aparece expresso em dois parágrafos soltos no texto dedicado ao livro já referido de Tasso da Silveira, A Igreja Silenciosa.

Estamos num momento em que o fervor nacionalista, paradoxalmente, quer tomar o passo quase que em todo o mundo aos sentimentos cosmopolitas, de que o bolchevismo foi a última fórmula alucinada. O nacionalismo, entretanto, como se apresenta agora na Europa, pode que se torne um antípoda, também funesto, embora igualmente passageiro, daquele monstruoso reversor de valores. Com uma diferença: Lenine é o cataclismo, não há dúvida, mas que representa um sonho, embora unilateral; Mussolini pode vir a ser a galvanização que barbariza, em todo caso sem a justificativa de um verdadeiro ideal. Se Lenine contagiasse o mundo inteiro, este 
se transformaria numa anarquia organizada à procura de uma amanhã melhor que o de hoje. Se Mussolini definitivamente prevalecesse, principiariam as nações por libertar-se, talvez, de muito do que nelas já está moribundo, mas ao mesmo tempo de tudo que lhe resta de superior, para acabarem em mútuos ataques de feras entre si, sem que pudéssemos esperar no fim um resultado compensador de tão lamentável retrogradação.

Felizmente que o nosso nacionalismo está muito longe de ser assim, e em ti [Tasso da Silveira], então, ele se reveste do mesmo incontentamento lírico que tens de tudo e de todos, principiando por ti próprio (OC, vol. II, p. 255).

A "hora" nacionalista, católica, mas também "futurista" e de "radicalismos" reflete, de forma evidente, as relações entre a sociedade brasileira e o restante do planeta, unido sob o domínio e as crises do capitalismo. A partir de 1915, os laços entre os países e a consciência em torno dessas crises aparece com mais força aos intelectuais, de modo que o pensamento nacionalista surge como uma oposição, mais ou menos reacionária, ao internacionalismo das relações econômicas e políticas cada vez mais evidentes. Como o próprio Nestor Vítor afirma em 1921:

\begin{abstract}
Atravessamos uma hora em que as nacionalidades ou já estão passando ou irão passar daqui a pouco por crise tremenda, hora em que elas vão ser experimentadas de maneira tal, que só as mais vivedouras é que ficarão de pé. (...)

A geração atual tem, pois, sobre seus ombros uma responsabilidade formidável, sobretudo nas terras cuja organização ainda se processa.

Vem daí o movimento nacionalista que por toda parte se está produzindo, e, por instinto, refletindo em quase todas as manifestações artísticas (OC, vol. II, p. 189).
\end{abstract}

A consciência da crise, a responsabilidade da nova geração e o movimento nacionalista acabam formando critérios para uma crítica engajada, em que as noções de pureza e de uma arte universal, presentes em seus primeiros escritos, tornam-se inócuas. A tradição nacional, supostamente criada pelos românticos, pode-se tingir do espiritualismo moderno, porque esse é ativo e otimista.

De Graça Aranha, Euclides da Cunha, Alberto Torres, Rocha Pombo e implicitamente Farias Brito, para cá, é que, porém, tal interesse passou a ganhar certo ardor, que o tornou lírico ou épico, até místico, como observei escrevendo sobre o derradeiro desses autores.

Esse forte sopro poético e esse misticismo (o último entendido à moderna) é que nos fazem ir entoando instintivamente com os românticos, os quais, aproveitando o grande arranco facultado em todo ocidente à hora literária e artística em que surgiram, puderam ser corajosamente brasileiros, como ainda não se fora até então. $\mathrm{O}$ que, todavia, distingue qualquer dos nossos últimos escritores eminentes, quer os autores de ficção, quer os sociólogos ou filósofos, o que os distingue mais necessariamente dos nossos românticos, é a preocupação, consciente ou inconsciente, de fazer a psicologia rigorosa, embora não pessimista, de nós mesmos, ou pelo menos a de representarem genuinamente o que já possamos reconhecer como nossa psique, e daí também a de nos indicarem uma orientação acorde com o nosso modo de ser (OC, vol. II, p. 190). 
A criação, nessa perspectiva de Nestor Vítor, de uma tradição desde os românticos, com a novidade de traços "modernos" de otimismo e ação, conformaria essa crítica engajada politicamente no nacionalismo literário. O que demonstra novamente o quanto Vítor esteve profundamente ligado ao tempo e à formação social da República Velha, ainda que seu nome sempre esteve ligado ao breve surto simbolista e esse, por sua vez, tivesse a aparência de ruptura com essa formação. Na verdade, o que parece haver na história cultural e política do país são reformas que buscam corrigir erros de constituição da estrutura social, sem, contudo, confrontá-la em seus fundamentos.

O nacionalismo desse período parece ter esse significado. No fundo, o que a intelectualidade faz é expressá-lo de uma forma difusa.

Ao referir-se, por exemplo, ao "entusiamo pela educação" e aos que aderiram aos planos e soluções para a questão educacional, o estudioso Jorge Nagle, em "A Educação na Primeira República", afirma que, a partir de 1915, aparecerá “aqui uma parcela que se liga ao fervor ideológico do final do Império; mas, agora, este é manifestado pelos próprios republicanos desiludidos com a República existente, República que procuram redimir" (NAGLE, 1985, p. 262). Ou seja, em todos os setores da vida intelectual, há uma difusão de um nacionalismo cuja preocupação é revitalizar o país, para colocá-lo em posição favorável frente a conjuntura internacional, sem questionar os fundamentos econômicos em que se erigiu a República.

Ainda conforme Nagle, há todo um envolvimento de intelectuais e instituições que configuram esse momento nacionalista. É salutar lembrar a participação do consagrado escritor Olavo Bilac nesse momento e os agrupamentos que surgem expressando esse difuso nacionalismo:

Inicia-se com as conferências de Olavo Bilac e com a consequente formação da Liga da Defesa Nacional (1916). Visa a clamar contra 'a gravidade da nossa situação moral', cujo remédio se encontra, de um lado, no serviço militar, para fazer frente ao perigo externo representado pela cobiça internacional, de outro, na instrução, para combater o perigo interno, que se manifesta pela quebra de unidade, pelo depauperamento do caráter, pelo definhamento do patriotismo...

Difundem-se as pregações cívicos-patrióticas pela fundação das Ligas Nacionalistas. E para enriquecer um pouco mais o quadro, não se deve esquecer a atuação do grupo agressivo que se formou em torno da revista Brazílea (1917), de onde surgirá a Propaganda Nativista (1919) e a Ação Social Nacionalista (1920), esforçando-se para 'repensar o Brazil' e 'repensar o brazileiro'. Sistematiza-se, desse modo, o programa nacionalista (ibidem, p. 262). 
Os termos dessa situação histórica dão contorno ao chamado problema "moral". Novamente, a insuficiência de meios da classe média urbana de fazer frente aos reais problemas econômicos e políticos que a República enfrentou desde o seu início levou a que setores dela se alinhassem-se ao pensamento conservador. Nestor Vítor participa desse movimento de aproximação com os católicos, porque subsistia nestes a "questão moral". Ao escrever sobre o livro Problema Vital, de Monteiro Lobato, em abril de 1919, Vítor assim se pronuncia:

\footnotetext{
Poderemos discordar ainda apenas quando V. afirma que, nesta terra, 'programa patriótico, e mais que patriótico, humano, só há um: sanear o Brasil'. Já não discordaríamos se $\mathrm{V}$. ampliasse a significação dessa palavra sanear por modo a não se referir apenas à obra do médico que cura o corpo, mas também dos médicos que curam do espírito e do coração.

Nisto eu estou com os positivistas: julgo que as epidemias e endemias, se não provêm das crises morais, pelo menos com elas se agravam. Parece-me, portanto, que ainda há exagero, unilateralidade, neste seu novo modo de ver.

Do que o Brasil está sobretudo necessitando é, creio eu, de acordar da 'bestificação' em que caiu desde o 15 de novembro, de tomar posse de si mesmo, depois destes trinta anos de República, que não tem sido sua, mas dos politiqueiros e dos militares. (OC, vol. II, p. 140).
}

Misturam-se aí as questões "morais" e "políticas" na avaliação do momento e da história mais recente do Brasil. Não é à toa, como já destaquei em outro momento, a participação política de Nestor Vítor, tendo sido “eleito deputado estadual, no Paraná, em 1917”, e tendo “o seu mandato renovado em 1919” (CARVALHO, 1998, p. 14). Ele acompanhou o movimento das classes médias urbanas que almejavam transformar a "República oligárquica em República liberal", conforme afirma Boris Fausto em História Concisa do Brasil.

Um indício claro da maior participação política da população urbana foi a eleição de 1919. Rui Barbosa, candidato derrotado em 1910 e 1914, apresentou-se à eleição, enfrentando Epitácio Pessoa, para realizar protesto. Mesmo não tendo o apoio de qualquer máquina eleitoral, obteve cerca de um terço dos votos e venceu no Distrito Federal (FAUSTO, 2001, 171).

O exemplo de Fausto pode ser associado às aspirações democráticas de Nestor Vítor, que buscou atuar nas eleições de Rui Barbosa, como antes afirmado, contrapondo-se aos indicados pelos "politiqueiros" dos Estados dominantes e aos candidatos militares, cuja participação decaíra após os anos iniciais da República.

Assim, como se vê, é um quadro complexo em que aparecem vários elementos que dão o contorno e as questões do pensamento de Nestor Vítor: o nacionalismo difuso, o 
espiritualismo de matiz romântica, a reação católica, a política oligárquica e a posição das classes médias urbanas. Voltarei a tratar desses elementos, sobretudo, no terceiro capítulo deste trabalho, ao falar das transformações do pensamento de Vítor em relação à arte e à estética simbolista. $\mathrm{O}$ que objetivei até agora foi fazer uma referência, ainda que mínima, a esses elementos histórico-culturais, sem a qual não é possível observar seriamente a produção do crítico.

Desse modo, de 1915 a 1930, temos um conjunto grande de escritos reunidos nos três volumes das Obras Críticas, alguns dos quais foram, como já afirmei, coligidos em livro somente após a morte de Nestor Vítor.

Dos escritos, publicados e reunidos em livro ainda em vida, temos, no volume I: Três romancistas do Norte, que trata de conferência realizada em 15 de outubro de 1915 e publicada em janeiro de 1916, e Farias Brito, escrito e publicado em 1917.

No volume II, temos: "Matias Aires", publicado em 1915, originalmente publicado na Revista Americana e o livro Cartas à Gente Nova, já referido, cuja publicação ocorreu em 1924, mas retoma os textos em forma epistolar dos anos anteriores. São ao todo 47 textos, dos quais apenas os dois primeiros remetem à fase anterior à Guerra, já citados na seção anterior: "Sangue" e os "Os Inconfidentes"; os outros 45 textos já partem de 1916. O primeiro é um artigo sobre o ensaio de Jackson de Figueiredo, "Garcia Rosa", de janeiro de 1916; o último, o texto já citado “A Igreja Silenciosa por Tasso da Silveira”, de novembro de 1922.

Ainda nesse volume de Obra Crítica, é reunido o livro Os de hoje, que foi publicado em 1938, portanto, como obra póstuma, reunindo ensaios e artigos, sobretudo, sobre autores contemporâneos, modernistas, na quase totalidade dos textos. Na folha de rosto original do livro, além do título Os de hoje, figurava o seguinte subtítulo: "Figuras do movimento modernista brasileiro". As datas vão de 1921 com o texto "Um pouco de Crônica da Vida Literária" a 1930, quando aparece um artigo de comentário crítico, "9 poetas nuevos del Brasil por Enrique Bustamante y Ballivián” sobre a tradução de nove poetas brasileiros pelo literato peruano.

No volume III, que só compreende artigos e estudos não publicados em livro, e que só veio a lume em 1979, temos também um grande quantidade de textos desse período. Da parte intitulada "Homens e Temas do Paraná", encontramos oito artigos, que vão de maio de 1915, “Dias da Rocha Filho", a maio de 1930, "Página Paranaense”. Da seção "Colaboração para o Correio da Manhã", temos treze artigos do período, apresentados em ordem cronológica: de 
junho de 1927, "O Poeta das Algas e Musgos", a agosto de 1928, "Desenganados", sobre contos póstumos de Artur Azevedo. Na seção seguinte, "Colaboração para O Globo", os vinte artigos começam em janeiro de 1927, "Farias Brito, no décimo aniversário da morte desse pensador" e encerram-se em julho de 1930, "Antecipações e Relembrança" sobre dois ficcionistas contemporâneo. Da parte final de artigos, "Colaboração para outros periódicos", temos oito artigos dessa fase, começando por "José Veríssimo" de janeiro de 1919 e terminando por “O espírito de Dostoievski”, de julho de 1930.

Como se vê, uma produção bastante significativa de artigos e textos curtos que, em geral, não apresentam mais o caráter de ensaios dos primeiros estudos do crítico e que se moldam à própria empresa do jornalismo, já que se trata quase que exclusivamente de textos para jornais e revistas.

No entanto, o estudo de maior fôlego do período, Farias Brito, de 1917, impresso já como livro, demonstra algo das preocupações intelectuais de Nestor Vítor, dirigidas então não só ao campo literário, já que o estudo trata da obra de um "filósofo" e não de um literato como antes acontecia.

Ainda que retomando sistematicamente, nesse período, a história do simbolismo em vários artigos e fazendo um resgaste da própria história da literatura brasileira com a filiação dos novos escritores às tendências e movimentos do século XIX, percebe-se, como já disse, um forte senso moral na crítica literária que se estabelecerá nesse período, fazendo com que o autor muitas vezes se aproxime da crítica gramatical ou determinista que ele julgava limitadas no final do século XIX.

Assim, de um lado, ao criticar os epígonos ou ao rememorar os mestres dos movimentos do século XIX, teremos como critério a aferição se a obra e o autor aproximamse ou não do jeito "nosso" de ser, isto é, de nossa suposta "brasilidade". Naturalistas e epígonos, por exemplo, estariam fadados ao fracasso, nessa perspectiva, porque nunca se ligaram profundamente ao sentimento espiritual, não materialista, de nosso povo. De outro, ao falar dos jovens escritores modernistas, terá como critério de diferenciação, por exemplo, entre os "andradistas" (Oswald e Mário de Andrade) e os "verde-amarelistas" ou os “espiritualistas", o uso da linguagem, que é adequada nestes e não naqueles, já que aqueles abusariam das influências das vanguardas estrangeiras, sobretudo, das influências do “dadaísmo" e do "supra-realismo", conforme ele denominava então. 
É nessa fase que acredito haver, inclusive, uma revisão negativa da obra literária de Cruz e Sousa por Nestor Vítor, porque os critérios de nacionalidade e de linguagem aparecerão com força para agora legitimar o que a crítica oficial do século XIX já havia apontado no poeta simbolista e contra a qual Nestor Vítor havia se lançado, defendendo outros critérios e outros valores que não teriam sido vistos pela recepção crítica do final do século. Em 1923 é quando Vítor organiza as Obras Completas de Cruz e Sousa, e a introdução a esta obra, embora não esteja reunida em suas Obra Crítica, será por mim analisada.

Não se pode, no entanto, falar de completa transformação de Nestor Vítor porque muitos dos traços que aparecem nessa fase de maior consagração (final dos anos 10 e anos 20) já estavam anunciados, de forma dispersa, nos textos dos períodos anteriores.

Como homem de seu tempo, refletindo as contradições das diferentes esferas da vida social, ele assimilou elementos conservadores que ganharam força com a Primeira Guerra Mundial, conquanto mantivesse vivas as lembranças de sua fase heroica, quando a luta, seja no campo propriamente político, seja no campo cultural, das letras, exigiu que estivesse aberto às novidades do tempo, em uma atitude sempre bastante "simpática" com os novos escritores, ainda que sem aderir completamente a nenhuma das novas correntes que se apresentavam e buscando pretensamente mediar o surgimento dessas correntes de pensamento com a tradição e a formação social de que ele era tributário.

A adesão mais ou menos consciente de Nestor Vítor à "reação espiritualista" acabou por refletir a leitura que fazia dos novos escritores com base na sua experiência cultural do passado. Considerando que a corrente "místico-simbolista" que ele buscou erguer e defender não pode vencer, acreditou que os espiritualistas, como Jackson de Figueiredo e Tasso da Silveira, representariam a vitória que ele sempre esperou contra a mundanidade e o materialismo que ele via nas manifestações literárias de sua época.

Como dirá em uma carta avaliando o livro de Tasso da Silveira, Fio D'Água, em 24 de maio de 1918, sua crença é na vitória da nova geração contra a geração da qual ele fez parte, como fração minoritária.

Diante da balbúrdia do tempo, em que as letras se vão mundanizando cada vez mais no Brasil, por maneira a tornarem-se apenas um passaporte para a epicuréia barata aos que têm por ideal a mistificação de todos os valores, ideal muito lógico, aliás, dada a insignificância do que neles, efetivamente, se apura; diante dessa triste, ridícula mascarada, ainda bem que se organiza a reação, correspondente ao que em outros terrenos se prepara também. 
Vens, meu Tasso, desde já formando para este outro lado, único que tem futuro porque é o único que se alimenta de fé. Tuas possibilidades fazem com que quantos contigo convivem augurem-te um lugar à frente, nas fileiras porque optaste, como representante da nova geração.

Possa eu ainda assistir à tua completa vitória, e à de outros teus companheiros, que também estremeço, como a garantia de que fecharei os olhos sorrindo, quando for descansar no meu túmulo (OC, vol. II, p. 110).

A partir de 1917, com Farias Brito, Nestor Vítor via renascer suas esperanças de que a vertente não-materialista, a "tendência subjetivista", pudesse triunfar na cultura brasileira.

A ideia, vinda com força a partir dos espiritualistas, com a reação católica, de que o povo brasileiro era um povo religioso e avesso aos cientificismos da moda, acabava por legitimar todo o seu percurso por tentar manter viva a chama da literatura "subjetivista", oposta à literatura "objetivista", como ele classificava toda a literatura realista, parnasiana e naturalista.

Com efeito, a tradição romântica resgatada e o surgimento de novos escritores, espiritualistas, parecia fazer com que o simbolismo tivesse um elo bem consistente na história literária brasileira e as tendências que foram vitoriosas em seu tempo de juventude, o naturalismo e o parnasianismo, mostrassem seu caráter de excrescência em nossa cultura.

É como se o futuro reservasse a justiça por que tanto clamou Nestor Vítor até então. A sua trajetória intelectual estaria referendada pelos desdobramentos da própria história cultural do país. A sua biografia representaria também um esforço para elucidar o tempo vivido e ser um representante da "hora" vivida.

Como busquei demonstrar nesse capítulo inicial, é provável que o conjunto de posições políticas, posturas estéticas e intenções culturais que o crítico Nestor Vítor foi assumindo em vida não correspondesse à realidade do momento, ou melhor, correspondesse não tanto ou não somente pelas interpretações que ele pode fazer dos autores e das obras que ele foi analisando, mas, sobretudo, pela trajetória intelectual materializada em seus escritos, que refletia as condições materiais desse período. Reflexão mediada pelas escolhas, pelas leituras, pelas relações sociais contraídas durante os anos de formação e por toda a sua vida.

$\mathrm{Na}$ tentativa de apreender algo da materialização desses elementos e fatores nos escritos do crítico, escolhi como tema do próximo capítulo a questão da "política literária". Expressão que aparece explicita e implicitamente em vários textos e que permite começar a pensar a relação entre as diferentes esferas da vida social na sua obra, buscando, assim, fugir da caracterização consagrada de que Nestor Vítor foi somente um crítico simbolista ou do 
movimento simbolista. Caracterização que, embora, em parte, verdadeira, acaba por pouco explicar a situação concreta desse homem de letras na e da República Velha. 


\section{A "POLÍTICA LITERÁRIA": INSTRUMENTO DE ANÁLISE DA CRÍTICA}

Crítica não exclui parcialidade: que esta seja involuntária é quanto se pode exigir de quem toma da pena para julgar.

Nestor Vítor (OC, vol. II, p. 165)

Antes de adentrar na análise da crítica de Nestor Vítor, de onde extraio seletivamente a expressão "política literária" e seus desdobramentos para pensar a crítica cultural na República Velha e o campo literário brasileiro, quero rapidamente passar pelo que se considerou "crítica literária" no período da Primeira República, a partir da leitura que estudiosos fizeram da obra dos principais nomes da geração de 1870 e a partir da leitura que o próprio Nestor Vítor fez desses nomes. Revelando, desse modo, como o programa de uma crítica "voluntariamente imparcial" como se depreende da epígrafe acima acabava sendo uma exigência contra a crítica "oficial”, um modo pelo qual Nestor Vítor buscava denunciar os julgamentos e avaliações pessoais que extrapolavam o que hoje consideramos como "literário".

\subsection{A crítica no campo literário brasileiro: a parcialidade voluntária}

Na nota ao seu livro de 1924, Cartas à Gente Nova, Nestor Vítor busca transmitir a ideia de que sua crítica buscava ser bastante abrangente, pois o livro seria "até o presente, o quadro mais numeroso que aparece da gente nova do Brasil nas letras, até sem excluir a própria crítica que eles vêm fazendo uns dos outros entre si” (OC, vol. II, p. 73).

A abrangência da crítica ligava-se, portanto, a um rico panorama do que há quinze anos (1909 a 1924) se produzia em poesia, em prosa e em crítica no país, cabendo aos "moços e velhos" a tarefa de julgar a sua imparcialidade nas escolhas e nas opiniões emitidas.

A proposição de Nestor Vítor, nesse período, quanto à crítica era bastante generosa, muito mais do que pôde ser, por exemplo, a crítica de Sílvio Romero, a quem as apaixonadas polêmicas revelariam as motivações pessoais:

O historiador não se limita, portanto, a classificar e a descrever os documentos literários, posicionando-se sempre de modo polêmico e apaixonado. A crítica e história literárias de Romero, assim como suas polêmicas, estão marcadas por motivações pessoais, que o levaram ao elogio irrestrito de Tobias Barreto, em detrimento de autores de maior importância, como Castro Alves ou Machado de Assis (VENTURA, 1993, p. 79-80). 
Em Nestor Vítor, reiterando as palavras de Candido, houve uma tendência de passagem do "historicismo à crítica estética", o que significava não só uma disposição diferente, em parte, de nosso crítico, em relação à geração de 1870, expressa em Sílvio Romero, Araripe Júnior e José Veríssimo, mas uma tomada divergente de posição no interior do campo literário.

Ainda que tal campo, como parte do campo cultural, na República Velha, não houvesse alcançado a "automatização progressiva do sistema de relações de produção, circulação e consumo de bens simbólicos” (Bourdieu, 2004, p. 99), a marginalização em que foram colocados os escritores identificados ao simbolismo e ao decadentismo em fins do século XIX permitiu a Nestor Vítor solicitar a imparcialidade na crítica literária. Esta exigência, portanto, não nascia de uma relativa autonomia das relações de produção artística, impossíveis ainda nas condições de mercado de bens simbólicos do período, ela era antes uma exigência contra o próprio campo literário, em que as preferências pessoais, refletindo determinações outras que não as propriamente "literárias", atuavam fortemente.

Aliás, a disposição “diferente" de Nestor Vítor não deve ser vista como uma qualidade em si, um atributo essencial para revisar a sua posição na historiografia literária, ainda que a ideia de uma crítica mais "estética" pareça trazer em si um valor positivo.

Com efeito, tornou-se comum avaliar os críticos do passado pela adesão maior ou menor a uma perspectiva "estritamente literária". Assim consagraram-se os principais estudos sobre Sílvio Romero, Araripe Júnior e José Veríssimo. A análise dos “métodos críticos”, das formas em que se conformaram os instrumentais teóricos teve maior importância do que a apreensão das funções dessa crítica, do papel que elas desempenharam nos contextos de produção cultural.

Em estudos como O método crítico de Sílvio Romero, de Antonio Candido, A tradição do impasse, de João Alexandre Barbosa, e a "Introdução", de Alfredo Bosi, à coletânea de textos Araripe Júnior: teoria, crítica e história literária, apenas para citar os estudos mais importantes de nossa história literária, há uma compreensão comum sobre o distanciamento da crítica da geração de 1870 para com o texto literário em si. Embora a todo momento afirme-se que uma leitura "estética" das obras literárias não poderia estar completamente no horizonte de recepção dos críticos do passado, revela-se a ausência "determinante" dessa leitura. 
Candido chega a afirmar que a permanência intelectual de Romero esteve sempre ligada justamente ao fato de ter sido muito mais um crítico de ideias do que um crítico literário propriamente dito e por ter "sido por excelência o representante dos anseios intelectuais da sua geração" (CANDIDO, 2006b, p. 49). Entretanto, tanto em Candido, quanto nos demais autores que estudaram a tríade do século XIX, subsiste sempre o chamado "impasse": a análise da obra literária esteve sempre subordinada a algum projeto mais amplo de crítica que fazia desaparecer a perspectiva "estética".

Conforme nos explica Roberto Ventura, em Estilo Tropical, no interior do modelo naturalista a história literária estaria subordinada à história geral. Não haveria nenhuma tentativa de buscar uma autonomia absoluta ou relativa do "literário".

\footnotetext{
Tomada como parte do processo histórico geral, a história literária se aproximou dos métodos da história e das ciências naturais, de modo a adotar bases científicas e objetivas. Com isso, a abordagem da literatura se ajustou ao ideal da objetividade histórica, em que as coisas devem ser comprovadas como se deram, sem a emissão de juízos de valor ou qualidade. A descrição do passado se restringiu ao cânone das obras e escritores consagrados pela tradição, o que levou à exclusão dos textos divergentes do modelo dominante de literatura.

(...) Hippolyte Taine e Ferdinand Brunetière aplicaram o conceito de evolução à história literária. Taine se baseou na concepção hegeliana de evolução, para inserir a evolução literária na história geral, concebida como unidade organizada. (...)

Ao transpor os métodos das ciências naturais e os princípios da explicação causal, tais enfoques colocaram, em primeiro plano, os fatores externos e reduziram a singularidade das obras aos fatores extrínsecos ou a um conjunto de "influências" (VENTURA, 1993, p. 164-5).
}

A apreensão da história literária como parte da história geral não soaria estranha se se pusesse em primeiro plano a função que a crítica assume no período. Mais do que perceber o aspecto negativo que a importação dos modelos de crítica cientificista teve para a apreensão do "literário", poder-se-ia focar no significado de tal apreensão no interior do campo em formação.

Nesse sentido, a crítica naturalista teve como mérito uma intervenção sobre a realidade social do último quartel do século XIX e início do XX, como fica mais evidente na crítica militante de Romero. As crenças depositadas no futuro da República, que são igualmente fortes e conformam também o espírito de Nestor Vítor, imprimem, por exemplo, um significado diferente à crítica brasileira em relação à europeia, conforme defende Luiz Roberto Cairo em livro sobre Araripe Júnior: 


\begin{abstract}
Nesta história de rotulá-los de realistas, na verdade uma simplista transposição importada de rótulo mascara uma diferença de perspectiva do movimento realista europeu e brasileiro, consciente e cristalinamente percebida pelo menos por Araripe Júnior: o pessimismo, essência do realismo europeu, produto de uma sociedade decadente, em oposição a um realismo brasileiro, em sua essência otimista, reflexo de uma sociedade em plena ascensão. Isto já impossibilita a importação tranquila do cânone realista que, por mais fidedigno que fosse ao modelo europeu, chegou até nós travestido e com espírito próprio (CAIRO, 1996, p. 40).
\end{abstract}

Partindo dessa perspectiva, de diferença no uso dos modelos estrangeiros, o que diferencia, essencialmente, Nestor Vítor da tríade da geração de 1870 não é propriamente a sua visada "estética", já que, como veremos, essa visada também é imiscuída da apreensão dos "fatores externos" de que fala Ventura e a sua crítica, de cunho impressionista, vagueia por determinações sociais, políticas e culturais mais amplas do que somente sobre a estrutura específica dos textos literários. O que o diferencia Vítor é estar posicionado no campo literário como produtor e leitor de "textos divergentes do modelo dominante de literatura", por estar fora do cânone já estabelecido e que estava sendo reproduzido e produzido pela geração de 1870 .

Embora o simbolismo, enquanto um movimento que se propunha voltado para a "forma", possibilitasse a Nestor Vítor um olhar para os "fatores internos" na constituição da peça literária, ele, por si, não garantia uma visada crítica essencialmente diferente a dos críticos naturalistas. Essa visada simplesmente não existia. Não existia, por um lado, porque a autonomia relativa do campo literário não havia se constituído antes e durante a República Velha, já que a sua constituição dependia, segundo Pierre Bourdieu, também de condições objetivas, exteriores, portanto, à vontade dos produtores do campo ${ }^{13}$; por outro, não existia porque os críticos não estavam separados da vida político-social, participando de atividades políticas regulares. Sílvio Romero foi deputado pelo Partido Republicano; Araripe Júnior foi Diretor Geral da Instrução Pública e logo Consultor Geral da República; José Veríssimo foi, ainda no Pará, Diretor de Instrução (espécie de Secretário de Educação) e, no final da vida, fundador da Liga Brasileiro pelos Aliados; e nosso crítico, Nestor Vítor, foi duas vezes deputado e também membro da Liga.

13 Penso aqui na "lógica do processo de autonomização" de um campo presente no texto "O mercado de bens simbólicos” em A economia das trocas simbólicas, p. 100-104, no qual o sociólogo elenca condições objetivas para que um campo se autonomize, o que significa funcionar de forma mais ou menos independente de imperativos econômicos e sociais externos às regras internas do campo, instituídas historicamente por seus produtores. 
A exemplo da função dos "periodistas" do século XVIII ou dos "homens de letras" do século XIX na Inglaterra, analisados por Terry Eagleton em A função da crítica, os críticos brasileiros formados no século XIX são muito mais portadores e disseminadores "de um conhecimento ideológico genérico que exponente de uma habilidade intelectual especializada, alguém cuja visão sinóptica, não turvada por qualquer interesse estritamente técnico, é capaz de abranger toda a paisagem cultural e intelectual de sua época" (EAGLETON, 1991, p. 38).

É preciso, no entanto, apontar que falo aqui de uma função "a exemplo de", semelhante, mas não idêntica. A eficaz relação que existe entre os "periodistas" e a esfera pública, pensada por Eagleton, ou mesmo a mais tênue, mas existente autoridade entre os "homem de letras" e o público leitor não é a mesma que existe para os críticos brasileiros formados no século XIX.

As palavras de Vítor já transcritas no primeiro capítulo sobre a consciência desoladora da pouca importância que têm os literatos diante das modas da belle époque e que permite que todos "andem juntos", de todas as "teoria ou escolas" reflete o que ele mesmo chama de “queixa geral”. Para um Veríssimo, essa queixa contra o meio e o público reflete uma desilusão com o projeto de "regeneração nacional" da geração de 1870, fazendo com que se volte para a especificidade da literatura.

\footnotetext{
Descrente quanto à ação ou à influência das letras, Veríssimo considerava os movimentos culturais mais produtos do que fatores dos fenômenos sociais. A cultura literária nacional seria o reflexo da sociedade, com alcance reduzido ou nulo, incapaz de influenciar ou determinar os acontecimentos políticos. A República não resultaria, em sua interpretação, da renovação cultural da 'geração de 1870', esgotada na década seguinte. Essa descrença quanto à eficácia da palavra escrita limitou sua compreensão das relações entre literatura e sociedade, na medida em que exclui, ou pelo menos reduz, a ação daquela sobre esta. Mas rompeu, a partir desse ceticismo, com a visão romântica sobre a influência das letras no progresso social e com o cientificismo missionário de Romero (VENTURA, 1993, p. 119).
}

A divergência de Nestor Vítor, colocado entre os "principais críticos militantes da época" por Brito Broca (1975, p. 242), não é, assim, de perspectiva “teórica" ou "metodológica" para com os demais críticos, nem tampouco para com a função que a crítica poderia assumir nesse período como afirmei há pouco, mas pelo papel desempenhado no interior do campo literário, colocado inicialmente como o representante de uma tendência minoritária, não alinhada à estética realista-naturalista-parnasiana. 
Sem se compreender a identidade de propósitos históricos de Nestor Vítor com os demais críticos, não é possível avaliar a sua transformação entre os anos 10 e 20 do século $\mathrm{XX}$, quando, sem a sombra da tríade da geração de $1870^{14}$, ele assume a voz oficial da crítica brasileira e adere com força ao critério de nacionalidade que subsistia, sob diferentes formas, nos três críticos do século passado.

Sem se compreender a identidade de função da crítica e a diferença de papéis no interior do campo, não se pode observar a insistência com que Nestor Vítor, mesmo quando mais reconhecido no meio intelectual do Rio de Janeiro, continue a menosprezar a literatura naturalista e parnasiana, como forma de destacar uma das frações da nova geração de escritores, a dos neossimbolistas e, em seguida, a dos espiritualistas, como se atualizasse as antigas disputas no campo literário de final do século XIX. Como tendência cultural minoritária, pôde, mais do que os demais críticos, explicitar os mecanismos de legitimação da produção literária. Segundo Miceli (2001), os intelectuais em posição dominante negam as lutas no interior do campo.

\begin{abstract}
Não é por acaso que os intelectuais que ocupam uma posição dominante no campo de produção interno sempre tenham tentado, pelo menos - desde os figurões da geração de 1870 -, transmitir a imagem de uma intelligentzia nacional unificada, cuja missão mais urgente seria enfrentar os grandes demônios externos, que podem tomar os nomes mais diversos, como, por exemplo, 'o imperialismo', 'as corporações multinacionais', 'o capitalismo' etc. Sem minimizar o alcance dessas determinações e dos conceitos com que se costuma nomeá-las, convém lembrar que a invocação encantatória da 'ameaça' externa muitas vezes despista as próprias lutas internas, e com isso preserva-se a posição dos intelectuais dominantes, aliás os mais interessados em negar a existência de um campo intelectual cujos ocupantes estão em luta pela apropriação das espécies de capital disponíveis, ou seja, por tudo o que conta de fato na vida cultural (MICELI, 2001, p. 60-1).
\end{abstract}

Creio que não se trata, no caso dos "figurões da geração de 1870", pensar em uma negação sistemática das lutas, porque essas aparecem, de alguma forma, nas polêmicas que se desenvolvem nesse período e que Ventura pôde ilustrar no livro já citado ${ }^{15}$, mas pensar na omissão dessas lutas por meio de um código polido de silenciamento, como ocorre exemplarmente com Machado de Assis quando confrontado com as provocações de Sílvio Romero ${ }^{16}$.

14 Em 1911, 1914 e 1916 morrem, respectivamente, Araripe Júnior, Sílvio Romero e José Veríssimo. 15 Ver Roberto Ventura, em Estilo Tropical. História Cultural e Polêmicas Literárias no Brasil (1993). 16 Conferir Ventura, Estilo Tropical, p. 105. 
Sem colocar em primeiro plano a função cultural da crítica e as disputas no interior do campo, a insistência de Nestor Vítor em condenar e em ridicularizar os "materialistas" de sua época aparece mesmo como uma paranoia, como curiosamente descreveu Antonio Candido ao prefaciar a obra de Salete de Almeida Cara, A recepção crítica:

\begin{abstract}
Assim não pareceria a Nestor Vítor, para quem havia uma conspiração conscientemente montada pelos parnasianos, articulados com as potências do mundo, para abafar a glória dos simbolistas. Na sua boca de homem justo mas ingênuo, o apodo que forjou, 'bilaquiano', servia para classificar as pessoas, desvendar as conspirações e mostrar a generalidade de uma atitude iníqua. "Ele é bilaquiano" significava, na sua fala, diagnóstico, descrição e condenação. Mas apesar dos pesares e embora Salete não entre nessa amena paranoia, lá do céu dos críticos Nestor Vítor há de considerá-la 'antibilaquiana' e, em consequência, há de dar-lhe a boa palma. Mesmo porque a nossa autora avalia a obra dele com justeza: na mediania em que sempre se manteve, ele representava uma posição correta, pois era dos renovadores; só que não tinha recursos para defini-la melhor e se perdia numa revoada de sentimentalismo e de entusiasmo estético entre aspas (CANDIDO, in: CARA, 1983, p. IX-X).
\end{abstract}

O que parece a Candido como uma atitude ingênua e paranoica era, a meu ver, uma consciência da parcialidade que existia na crítica cultural do período. Se essa consciência se afigura mais ou menos exagerada, isso corresponde ao olhar de Candido, para quem, como expressa em $O$ método crítico de Sílvio Romero, o que importa é o “determinismo literário", isto é, o modo pelo qual as obras interferem umas nas outras, independente das influências sociais, econômicas e políticas que elas tragam em seu bojo e das disputas extraliterárias que existiram para que elas ingressassem no cânone.

Um olhar "interno" sobre o texto literário embora constitua momento da crítica de Nestor Vítor, como dos demais críticos influenciados pela modelo naturalista, não é o único momento dela. Daí que se apresente, ao crítico já formado no século XX, como uma "revoada de sentimentalismo e de entusiasmo estético entre aspas", uma vez que o impressionismo na crítica era a um só tempo busca de fugir ao modelo dominante, como também acontece com o último José Veríssimo lido por João Alexandre Barbosa, e interesse marcado, crítica parcial, em posicionar o sujeito da fala no interior do texto crítico. O impressionismo em Nestor Vítor assume assim o papel de "método" (sem rigor) e de atitude "política", meio de diferenciar sua obra das demais e favorecer a própria linguagem a que se vinculara inicialmente, a do simbolismo.

Nesse lugar do campo, Nestor Vítor pôde falar sobre a "política literária" que existiu na República Velha, que subestimou Cruz e Sousa e outros simbolistas e permitiu a posição 
consagrada de naturalistas e de parnasianos. Se, conforme afirmei antes, não é possível falar na total autonomia do campo, é possível pensar nas exigências subjetivas que seus produtores fizeram para sua constituição.

No reduzido mercado das letras, a consagração de alguns intelectuais, armados por ideias importadas, revela as necessidades que o contexto cultural brasileiro solicitava na República Velha, no contexto de passagem do sistema escravocrata para o sistema de trabalho livre.

É bom aqui lembrar o fato de que a tríade da crítica brasileira "embora tendo surgido no Realismo, atingiu a maturidade em plena efervescência do Simbolismo" (CAIRO, 1996, p. 40). Ou seja, a função de legitimação da crítica de Romero, Araripe e Veríssimo atua justamente quando é preciso avaliar uma estética que, ao menos em seu programa, contraria os pressupostos do modelo naturalista ao qual todos eles se vinculavam, e que trazia como principal representante um filho de ex-escravos e negro "sem misturas", Cruz e Sousa, o que punha em xeque a concepção corrente de que os negros eram a "raça" inferior. O mestiço de sangue poderia ser incorporado à imagem de Brasil que se buscava consolidar; a do negro, não ${ }^{17}$.

A negação sistemática de Vítor em relação ao naturalismo em literatura atuava menos como uma forma de obscurecer as contribuições que os literatos e os críticos dominantes no campo cultural proporcionavam, já que, como disse no primeiro capítulo, ele é obrigado, participando desse meio, a tratar da obra desses escritores, reconhecendo muitas vezes o seu valor intelectual, e mais como uma maneira de revelar os fios das lutas internas ao campo, apontando o combate, a disputa, e a própria arbitrariedade dos juízos críticos.

Assim, colocados lado a lado, de forma abstrata, descontextualizada, o naturalismo e o impressionismo na crítica podem não dar o sentido e a função que eles assumiram "na legitimação que a importação de 'ideias' e de 'escolas' cumpre em favor dos intelectuais que a exercem" (MICELI, 2001, p. 60).

17 Não quero aqui repetir as explicações já conhecidas sobre os modelos de legibilidade que atuaram na recepção inicial de Cruz e Sousa e dos primeiros simbolistas. Indico o livro já citado de Salete de Almeida Cara, A recepção crítica, que traz uma argumentação bastante convincente sobre a inadequação do modelo simbolista de literatura em relação ao modelo ideal de representação da realidade nacional defendida pela crítica literária do período, o qual impediu a leitura do texto simbolista. Do mesmo modo, para conferir a aceitação do mestiço, ver o livro de Candido, também já citado, $O$ método crítico de Sílvio Romero, em que o crítico avalia a posição do mestiço na obra de Romero como uma necessidade de adaptação ao meio, indispensável para o desenvolvimento do país. 
Nestor Vítor compreendeu, em algum grau, o significado que a adoção de um sistema de ideias importadas comportava. Na transição entre o crítico não dominante que ele foi até o início da Grande Guerra para o crítico que assume a voz oficial da crítica nos anos 20, revelase a "existência de um campo intelectual cujos ocupantes estão em luta pela apropriação das espécies de capital disponíveis, ou seja, por tudo o que conta de fato na vida cultural” (ibidem, p. 61).

Ilustrativo dessa "transição" é um trecho da carta de 31 de agosto de 1919, publicado originalmente na revista América Latina, de “curta duração", segundo o próprio Nestor Vítor, dirigida a Ronald de Carvalho, em virtude da publicação do livro de poesia Poemas e Sonetos.

$\mathrm{Na}$ carta, Vítor aponta, como é seu costume, as qualidades do autor em impressões reveladas por adjetivos como "nobreza", "elevação", "epicurismo delicado", no entanto, sem menosprezar o escritor, acaba por dar um tom de queixa à carta pelo fato de o poeta em questão representar uma corrente "ora em desenvolvimento aqui, e que resulta da influência dos simbolistas belgas e franceses" mas cujos imitadores em nosso país além de realizarem um "mimetismo tático" com os representantes do Parnaso, "velhos mestres da escola decaída em França", ainda omitem ou mesmo negam as afinidades com os "nossos primeiros simbolistas" que "inquietaram" aqueles "há vinte anos" (OC, vol. II, p. 150-1). "Inocentando" Ronald de Carvalho por essas omissões, atribui à sua formação europeia, ao pouco contato com os escritores e a cultura nacionais, o fato de que seu livro é desde o "romantismo para cá, tão flagrante e ingenuamente alienígena" (ibidem, p. 153).

Em outras palavras, Vítor demonstra os ressentimentos de outrora, quando os primeiros simbolistas foram desprezados e quando as disputas no campo só eram sentidas pelos "injustiçados", pelos marginalizados na "apropriação das espécies de capital disponíveis". Mas, nessa transição de papel dentro do campo cultural, demonstra também a voz oficial da crítica naturalista em que os critérios étnicos (a língua de "toque popular" que só pode vir "da convivência reiterada e apaixonada com o nosso povo") e mesológicos (a crítica à "paisagem" e à "atmosfera" europeias) ganham corpo e servem para afirmar o caráter "flagrante e ingenuamente alienígena" do livro de Ronald de Carvalho.

Desse modo, nessa carta, como em muitos textos, Nestor Vítor traz à luz, involuntariamente, os significados dos critérios adotados pela crítica. Aliás, essa carta será melhor analisada mais à frente porque é cheia de indícios da parcialidade da crítica, da política literária subjacente às práticas de leitura e de avaliação das obras. 
Mais do que isso: ao avaliar a alternância, por exemplo, de critérios críticos em Nestor Vítor, imagino poder olhar para a parcialidade voluntária da crítica do período, para a política literária que subsistia nas escolhas, nos elogios e nas recusas. Política inicialmente pensada como um jogo de relações extraliterárias que o literato e o crítico acabavam tendo de assumir no interior do campo literário.

\subsubsection{A parcialidade da geração de 1870 entrevista por Vitor}

As duas $\operatorname{cartas}^{18}$ que Nestor Vítor escreve para Ronald de Carvalho em 1919, a primeira de 31 de agosto, já citada, e a segunda de 10 de dezembro, em virtude de dois livros lançados no ano, o de poesias Poemas e Sonetos e o de história literária Pequena história da literatura brasileira, servem para ilustrar o modo como o nosso crítico via a obra da tríade da geração de 1870 e a parcialidade na consagração dos escritores do período.

Como os estudiosos do século XX já citados, Vítor também encarava as limitações na análise do propriamente "literário" na obra dos três críticos da geração de 1870. Não tanto porque ele próprio tivesse os "recursos" de que trata Candido (2006b) para avançar na crítica "estética", mas porque, na observação dos critérios de cada escritor, podia observar a parcialidade nas análises, identificar os pontos de contato e de afastamento com as suas próprias avaliações.

Sobre Romero, observou algumas características que os pesquisadores do século XX também observariam:

Sílvio Romero também não lhe pode oferecer concorrência com os seus dois grandes volumes. Antes de tudo, porque estes são dois e são grandes. Depois, é certo, o trabalho de Sílvio em nossas letras, conforme a opinião de Medeiros, 'foi prodigioso'. Ele, Tobias, Clóvis e Araripe, como críticos, marcam uma revolução nas mesmas. A propósito de Sílvio, principalmente, pode-se perguntar como o senhor pergunta: 'Quem se preocupara antes dele, tão ponderadamente, com a nossa poesia popular, com a misteriosa psique das duas raças aqui escravizadas pelo conquistador solerte e brutal? Quem descera, tão demoradamente, a sonda em nossa alma inquieta e medrosa, dolente e exaltada, de mestiços? Quem auscultara, com tanta precisão, o latejar desse caos étnico brasileiro?' Mas a sua própria história da

18 Há, na verdade, no ano de 1919, três cartas dirigidas a Ronald de Carvalho. A terceira é uma resposta à carta do poeta Ronald quando do julgamento de seu livro por Nestor Vítor. Embora o terceiro volume das Obra Crítica de Nestor Vitor não indique a data de publicação da carta de Ronald, ela só pode ter vindo à publicação na Revista América Latina, onde também escrevera Vítor, em setembro de 1919, já que a carta de nosso crítico de "Resposta a Ronald de Carvalho" é de 9 de outubro. Trata-se, portanto, de uma carta anterior à de dezembro, no entanto focada apenas em reiterar o caráter pouco "brasileiro" da poesia avaliada, tendo menor importância para a discussão presente neste capítulo. 
nossa literatura 'revê', como o senhor diz, repetindo a opinião geral, 'um temperamento franco de polemista desabusado'.

Quase de começo a fim, a propósito de cada autor que critica, faz Sílvio a crítica do que outros tinham dito sobre aquele personagem. Traz, conseguintemente, o leitor quase tão preocupado com a pessoa que lhe fala como com o objeto essencial daquela página.

Além disso, o sociólogo que ele é anda sempre antes do crítico literário propriamente dito. Ele é um Taine pelo avesso, neste sentido: um Taine de que o que se vê sobretudo são os andaimes, isto é, a ciência, as teorias, os a-propósito, senão os sem muito a-propósito do assunto em questão.

Acrescente-se a facilidade com que se apaixonava pró ou contra os autores a quem os comentara, atingindo às vezes até a cegueira, mas a facilidade com que não raro emendava a mão para cair em excessos opostos, porque no fundo Sílvio era uma criança, era incapaz de ódio, propriamente dito, a ninguém (OC, vol. II, p. 165-6).

Vemos aí um comentário bastante extenso e apropriado sobre Sílvio Romero: a dimensão relevante da obra que antes ele já referira como indispensável para conhecer a literatura brasileira, o significado da geração de 1870 ("uma revolução nas nossas letras"), o ineditismo na sondagem de alguns temas da cultura, o sentido biográfico e polemista da crítica, e o caráter "sociológico" e "generalizador" da sua empreitada intelectual.

Colocações muito próximas às que Antonio Candido ou Roberto Ventura desenvolveriam nos estudos anteriormente citados. A diferença entre a apreensão de Candido e a de Ventura seria a de que o primeiro, focando na "utilidade" da crítica de Romero, buscaria revelar como o crítico dava a palma "a quem a merecesse" (CANDIDO, 2006b, p. 174), desde que se verificasse a contribuição da obra à diferenciação de nossa literatura, enquanto o segundo, focando nas polêmicas de Romero, demonstraria a parcialidade do crítico que elogiava aos que tinha afeição, como Tobias Barreto, e tripudiava daqueles de quem discordava de opinião, a exemplo de José Veríssimo ou de Machado de Assis.

Nestor Vítor que tanto apreciava o trabalho intelectual de Sílvio Romero quanto identificava a sua parcialidade crítica pôde apreender as duas facetas não só porque compreendia a importância do crítico mas porque Romero também o ajudou nas disputas do meio em determinado momento.

Sílvio Romero também foi voluntariamente opositor aos grupos e às "panelinhas" que se formavam no Rio de Janeiro, tendo, por exemplo, publicamente criticado a "Castro Alves, a Valentim Magalhães, aos escritores fluminenses, ao governo e até aos anarquistas..." no discurso de recepção a Euclides da Cunha na Academia Brasileira de Letras em 1906 (VENTURA, 1993, 112). 
O caráter não-mundano e intransigente de Romero agradava a Nestor Vítor, além de que foi Romero o primeiro a fazer uma "larga página, a mais elogiosa possível" a respeito do poeta Cruz e Sousa em texto de $1905^{19}$. Ou seja, Romero tanto denunciou as panelinhas que também desagradavam a Vítor quanto se dobrou à obra de Cruz e Sousa. De um lado, Romero ajudou a revelar os padrões culturais, denunciando-os; de outro, participou das lutas e da política literária, retirando o ar de "sobriedade" e de "frieza" que José Veríssimo, por exemplo, encarnava na crítica literária do período.

Aliás, é curioso o fato de que, entre os três críticos da geração de 1870 , seja Sílvio Romero o que mais elogios recebeu de Nestor Vítor. Considerado o menos "estético", o menos "literário" entre os críticos, seria plausível que a escolha de Vítor pendesse mais para Araripe Júnior, cuja apreciação do simbolismo foi mais generosa, ou para José Veríssimo, o mais "estritamente literato", como o próprio Vítor afirma na carta de dezembro de 1919.

É, no entanto, justamente nesse ano, o de 1919, que ele lança o livro A crítica de ontem e dedica-o à memória de Sílvio Romero, o que vai provocar alguns anos depois as colocações, consideradas infames, de Alberto de Oliveira sobre a apreciação do poeta Cruz e Sousa por parte de crítico consagrado.

A polêmica, reunida no terceiro volume da Obra crítica de Nestor Vitor, é formada por três pequenos artigos que foram publicados no jornal $O$ Globo em abril de 1927, dois do próprio Nestor Vítor e um de resposta de Alberto de Oliveira.

O conteúdo da polêmica poderia ser resumida no fato de que supostamente Nestor Vítor teria utilizado sua influência junto a Sílvio Romero para convencer o crítico das qualidades do poeta morto. Como Sílvio “apiedou-se" da trágica história do poeta negro, teria escrito as linhas elogiosas a seu respeito, desconsiderando o fato de que Cruz e Sousa era um "metrificador sonoro e oco, quase absolutamente destituído de ideias" nas palavras de Alberto de Oliveira (OC, vol. III, p. 355). As duas cartas de Vítor são um ataque ao que ele considera “infantilidade do 'príncipe' dos poetas”, umas despeitadas considerações de quem não quer perder nem um pouco o brilho que possuía.

Independente da "verdade" do boato lançado contra Nestor Vítor e Sílvio Romero, o que a polêmica realizada por meio do jornal revela é o espaço de disputa para a consolidação do cânone literário.

19 O elogio, na verdade, remete a texto de 1899 quando Romero produzia um panorama da poesia para o Livro do Centenário, e que se reproduziu, em seguida, no livro Evolução do lirismo brasileiro. 
Alberto de Oliveira, imbuído ou não de convicção verdadeira, continuava a ver como ruim a produção do poeta Cruz e Sousa. Embora este estivesse morto, a obra simbolista e de seus epígonos confrontava-se, em termos programáticos, com a sua própria obra. Nestor Vítor, tendo ou não influenciado Sílvio Romero, não queria, nesse momento, explicitar a construção da "aura" em torno do simbolismo e da obra de seu amigo, preferia reafirmar a justeza da revisão dos julgamentos críticos àquela hora. Sílvio Romero, também já morto, poderia ser utilizado, independente da parcialidade ou não de suas escolhas, como voz de autoridade nas batalhas do campo literário.

No caso de Araripe Júnior, a crítica naturalista não impediu que o autor realizasse boas avaliações "estéticas" de obras particulares como O Ateneu de Raul Pompéia ou de autores como o citado Alberto de Oliveira, cuja leitura seria retomada por Vítor em suas próprias análises como a que realiza no ensaio "Alberto de Oliveira", de 1906, publicada em A crítica de Ontem. Cairo (1996) chega a afirmar, por exemplo, que a leitura de Pompéia feita por Araripe Júnior entra em choque com a crítica cientificista e permite uma aproximação bastante singular com o decadentismo e o simbolismo.

Creio mesmo que a sua condescendência para com os simbolistas tivesse, em parte,
sido resultado do impasse criado pela obra de Pompéia. Araripe Júnior via que
Pompéia fugia do pessimismo de Zola, percebia semelhanças no seu estilo com os
decadistas, mas se recusava a enxergá-lo como tal. O Simbolismo feria os princípios
da Ciência e Raul Pompéia, segundo ele, não poderia transgredi-los. Aí estava a
grande resistência de Araripe Júnior, o seu método era calcado nos princípios da
crítica científica, da estopsicologia, como a denominava Émile Hennequin. Era
dentro destes princípios que ele trabalhava, é por isto que a descoberta de Ruskin,
com a valorização da imaginação e a tentativa de combinar naturalismo e
simbolismo, veio abrir-lhe o horizonte para a condescendência que o levou bastante
próximo à aceitação do Simbolismo (CAIRO, 1996, p. 33).

Essa possibilidade de ler o simbolismo talvez estivesse ligado à suposta modernidade de Araripe em buscar as "propriedades formais da mensagem, reconhecendo a origem desta não em fatores genéricos remotos, mas na dinâmica existencial do próprio autor em face das tradições" (BOSI, 1978, p. XVII).

Mas as categorias "psicoestéticas", conforme Bosi, que apareciam em alguns textos críticos, bem como sua capacidade de avaliar o movimento simbolista sob uma perspectiva mais explicativa e menos normativa, como antes acontecera com José Veríssimo, não permitiu, todavia, que Araripe Jr. superasse o critério racial no julgamento do poeta Cruz e Sousa, o que, sem dúvida, também se chocava com a posição de Nestor Vítor e deve ter 
pesado na apreciação do crítico naturalista, que é o menos citado em toda sua produção intelectual.

De fato, além desse ensaio "Alberto de Oliveira", de 1906, em que Vitor acompanha algumas das opiniões de Araripe Júnior sobre o caráter da poesia do "príncipe dos poetas", há uma citação das palavras do crítico no artigo "Rocha Pombo, historiador", publicado em 06 de setembro do mesmo ano na revista Os Anais, sob o pseudônimo Nunes Vidal, utilizado como argumento de autoridade para defender o nacionalismo em "países novos" como o Brasil (OC, vol. III, p. 9). Depois de 1906, apenas na carta de dezembro de 1919 que venho citando, há novas menções ao nome de Araripe.

São quatro menções nessa carta: a primeira transcrita mais acima quando fala que, junto a outros, Araripe teria ajudado a "revolucionar" as letras nacionais com sua crítica; a segunda, quando, de relance, cita o crítico como um exagerado admirador de Gregório de Matos, demonstrando que Ronald era mais sensato ao seguir Sílvio Romero, destacando o caráter nativista do poeta baiano; a terceira, ao diferenciar a obra de Ronald da obra naturalista dos três críticos do passado, mostrando que "não é o livro de um naturalista como o foi Sílvio, sobretudo por suas teorias, Veríssimo, por seu temperamento, por sua intuição, Araripe pelos seus processos" (OC, vol. II, p. 168); e a quarta menção, em que reconhece a crítica mais "estética” de Araripe em relação ainda à tríade:

\footnotetext{
Vemos, assim, que já estamos a boa distância do poderoso, mas prosaico tumulto de Sílvio, da forte, mas excessivamente desenganada e vetusta sabatina de José Veríssimo, mesmo do estético, mas muitas vezes por demais fantasioso diletantismo de Araripe Júnior (ibidem, p. 168).
}

Esse reconhecimento em torno de Araripe contradiz a maior importância que Vítor objetivamente atribui às obras de Veríssimo e Romero. Provavelmente, ele deve ter percebido que o crítico naturalista mais 'estético" "apesar de ter escrito pouco sobre os simbolistas, trataos com uma ponta de curiosidade simpática" (BOSI, 1978, p. XVII), o que, ao lado das leituras estrangeiras de Araripe, contribuiu para que ele, Nestor Vítor, não buscasse repreender sistematicamente as ideias dispersas em jornais e revistas do crítico cearense, como o fez ao tratar de José Veríssimo.

Este, o mais "literário" de nossos críticos (CANDIDO, 2006b; BARBOSA, 1974; VENTURA, 1993), também não soube apreender qualquer novidade trazida pelo movimento simbolista ou qualquer significação mais profunda da poesia de Cruz e Sousa. Houve, na 
verdade, por parte do crítico um despreparo para lidar com a poesia em geral segundo João Alexandre Barbosa.

(...) ao exigir, para a poesia, aquilo que positivamente quisesse dizer alguma coisa, indicava a impossibilidade de uma incorporação do texto literário que não se realizasse por via de uma referencialidade explícita, tornando, deste modo, remota não somente a sua adequação para com o novo em Literatura, como ainda a viabilidade de um discurso crítico específico (BARBOSA, 1974, 179).

Com efeito, a inviabilidade de compreensão do mais consagrado dos críticos "literários" do período, acendia os maiores rancores de Nestor Vítor e, sem dúvida, eram às apreciações críticas de Veríssimo que o nosso crítico mais devotava a exigência da imparcialidade voluntária.

Colocada em seu contexto original, a frase que utilizei de epígrafe a este capítulo indicava ao jovem Ronald de Carvalho, por ocasião de lançamento do livro Pequena História da Literatura Brasileira, que os críticos de seu tempo não conseguiram ser imparciais. Tratava especificamente do caso de José Veríssimo.

Conhecendo-se estes traços fisionômicos de José Veríssimo, explica-se facilmente
por que ele tem sempre mais ou menos frieza, senão pé atrás, não só com o primeiro
tipo de vulto que apareceu nas nossas letras [Gregório de Matos], como com todos
os boêmios ou simplesmente "malcriados", irregulares, que vieram depois deste.
O pior é que deixa um tanto de ser na realidade "europeu", perde, certo "tento da
civilização", fica elogioso demais, ou pelo menos demasiado efusivo,
comparativamente, quando fala dos tipos "sérios", de que procurou ser muito amigo,
de um Machado de Assis, de um Joaquim Nabuco, de um Taunay, de um Eduardo
Prado, coisa que naturalmente há de irritar os amigos e admiradores dos pobres-
diabos ricos de talento ou dos indisciplinados que lhe sofrem os severos conceitos.
Eu confesso que aos meus olhos, pelo contrário, assim se torna ele mais humano,
mais pitoresco e saboroso. Crítica não exclui parcialidade: que esta seja involuntária
é quanto se pode exigir de quem toma da pena para julgar (OC, vol. II, p. 165, grifos
meus).

O trecho acima é exemplar da forma "combatente" de Nestor Vítor, cuja "polidez habitual", como caracteriza Ronald de Carvalho, mascara a sua tomada de posição no campo literário. A frase que grifei revela a ironia ao falar da parcialidade na crítica de Veríssimo e a própria situação de Nestor Vítor enquanto um dos "admiradores dos pobres-diabos ricos de talento", a quem os grupos naturalistas impediram uma leitura mais compreensiva. 
Como um adversário de véspera ${ }^{20}$, José Veríssimo é muitas vezes citado pejorativamente por Nestor Vítor. Obviamente, como os demais críticos, por não ter lido razoavelmente Cruz e Sousa e os simbolistas, mas também por representar as altas rodas oficiais da literatura. A associação, por exemplo, com Machado de Assis, a quem Nestor Vítor sempre fez reticentes elogios e a quem ele chegou a associar aos gostos mundanos da belle époque como se pode ver no artigo que escreveu em 1906 sobre o livro de contos Relíquias da Casa Velha, deixa claro isso.

Felizmente já passou a ser de bom-tom, hoje em dia, ler ou dizer ter lido alguns dos nossos escritores; abrem-se os seus volumes mesmo no bonde. Se é um livro que acaba de ser posto à venda, cujas primeiras páginas se vão cortando para satisfazer a ânsia da curiosidade, ainda mais chique (OC, vol. I, p. 379).

E algumas páginas à frente:

(...) Fecha o livro com duas comédias, 'Não Consultes médicos', 'Lição de Botânico', que parece terem sido feitas principalmente para salão e com o fím de agradar mais as moças, acabando uma e outra em casamento (ibidem, p. 381-2).

A crítica a Machado de Assis e a José Veríssimo que, nesse ponto, pode ser vista como "ressentida", já que o nome daquele "uma vez lançado, ainda não sofreu nem mesmo um eclipse" (ibidem, p. 378), pode também ser vista sob o prisma das relações extraliterárias, a política literária, que os medalhões ${ }^{21}$ acabavam por consolidar.

A lógica de Nestor Vítor é bastante simples: embora reconheça o "bom uso da língua" e a "superioridade intelectual" de Machado, estas características não são autoevidentes nem

20 Em artigo publicado na revista Ciências e Letras de janeiro de 1919, intitulado "José Veríssimo", Nestor Vítor assim se refere ao crítico por ocasião do início da Grande Guerra quando ele e outros intelectuais tendo à frente Rui Barbosa formam a Liga pelos Aliados: "Veríssimo então se transfigura, ele como outros intelectuais com quem se achou de companhia. Uns eram seus velhos amigos; outros seus adversários de véspera (e nesse caso se achava quem escreve estas linhas); ainda terceiros havia até aí indiferentes para com ele, senão estremecidos com o estrênuo lutador, por questões ainda recentes" (OC, vol. III, p. 298).

21 Roberto Ventura assim se refere ao falar das polêmicas que Romero criou com Veríssimo, Machado e outros e que, provavelmente, agradavam a Nestor Vítor como dissemos no início dessa seção: "Os ataques de Sílvio Romero a Machado de Assis se inserem na sua atitude de combate contra todas as formas de oligarquia, incluindo as panelinhas literárias. Em discurso de 1908, declarou ter lutado pelo completo afastamento dos bandos e grupos de atividade política e literária, recusando-se a pertencer a agrupamentos, com exceção da Academia Brasileira de Letras, 'singular corporação eclética e amorfa', da qual apenas tomaria parte 'por honra da firma', sem frequentar suas sessões. Os grupos literários são, segundo Romero, 'verdadeiros clãs, em torno de alguns chefes, que se guerreiam uns aos outros e dão o santo e a senha para as exclusões dos que lhes não agradam'. Critica a turma de medalhões, liderada por Machado, com a participação de Veríssimo, Araripe, Joaquim Nabuco, Rui Barbosa, Lúcio de Mendonça, Capistrano de Abreu, João Ribeiro, Medeiros e Albuquerque, Graça Aranha e Oliveira Lima. Por meio desse grupo, fundador da Academia Brasileira de Letras, Machado exerceria 'uma espécie de política dinástica na literatura” (VENTURA, 1993, p. 102). 
garantidoras de sucesso. Entram aí, na canonização de Machado, por que tanto lutou José Veríssimo, um tanto de relações pessoais e de fé na opinião majoritária.

\begin{abstract}
É preciso conhecê-lo[Machado] um pouco de perto, ver como ele e é antes de tudo carinhoso e cheio de interesse para com os seus amigos, como tem desenvolvidos os sentimentos de afeto e de apreço, para achar as razões sentimentais dessas coisas, que nunca são conquistadas exclusivamente por superioridade intelectual. Ser superior nunca foi razão bastante para um homem se fazer amar.

De qualquer modo, o que é evidente é o fato da conformidade geral a esse sentimento de estima e de apreço, em que vai tanto de admiração pelo mestre no mundo das letras. Não há quem lhe negue hoje em dia e a muitos esse valor parece grande e raro: uns o sentem, outros vão nessa fé (OC, vol. II, p. 378).
\end{abstract}

Daí que, mesmo em 1919, quando já se passaram três anos da morte de José Veríssimo, Nestor Vítor ainda busque insistir no caráter parcial da crítica "efusiva", "elogiosa demais" que o crítico consagrado exibia em relação a certas figuras do meio literário.

Assim como na pena de Sílvio Romero 22 , "veríssimo" assumiu caráter negativo nos escritos de nosso crítico. Vítor utiliza o termo nos textos de sua primeira fase, como o que vemos em sua introdução ao livro de Silveira Neto, Luar de Inverno, publicado em 1900.

Ao tratar do poeta paraense, Nestor Vítor quer passar a ideia de que a época dos simbolistas é a atual ainda que isso ainda não apareça para os críticos "ruminantes" brasileiros que não percebem a onda universal. No texto, ele combate abertamente, apontando a política literária existente no campo. Ao mesmo tempo, com a ingenuidade própria dessa primeira fase, acredita no poder do "Verso" e da "Frase". Apesar de extenso, é importante transcrever um trecho dessa introdução.

De modo que o movimento literário que o instante presente oferece é naturalíssimo, esta perfeitamente de harmonia com ele, por mais antagônico que pareça aos observadores superficiais, aos providos de uma lógica míope, aos tardos ruminantes do mundo do pensamento. É uma flora esta que viça do humus estendido em lastro abundante na estação anterior; ela reverdesce com a sua primavera: por isso prevalecerá.

Lá para além do Atlântico já os veríssimos não se animam a fechar o olho numa malícia pequeninamente cética, ante tais afirmações, temendo que se os chame de cretinos. Mesmo os daqui, desde que se trate de produção peregrina, já se esfalfam por entendê-las, por lhes dar uma interpretação, por lhes fazer uma justiçazinha, que receiam atribuir-se uma negação absoluta de sua parte à ausência lastimável de paladar. Vão mais longe estes nossos hominículos ainda: para se inculcarem como a crème da imparcialidade, o ideal no que se chama pureza de alma, santidade de intenções, já deixam passar com uns adjetivos mais assim aqueles dos nossos companheiros que lhes parecem mais inóquos, mais bons moços.

Mas o que se chama o reconhecimento de que nós é que somos os homens que vieram para representar a hora no que ela tem de mais alto, de mais glorioso, no que

22 Recordo aqui o título e o tema de um dos livros de Sílvio Romero, voltado a criticar zombeteiramente José Veríssimo: Zeverissimações ineptas da crítica (1909). 
ela tem de mais magnífica, isso é o que, por enquanto, torcendo-se e retorcendo-se, numa cólica impagável de êmulos colegiais, verdes e estrábicos, eles procuram a todo transe esconder.

(...)

É claro que por fim, seja como for, só hão de triunfar o Verso e a Frase que dentre todos forem os melhores. Nem o claro que o seja por ausência de ideias, nem o obscuro que tal se faça para se fingir profundo, mas que, tudo bem visto, não represente mais do que uma calvície intelectual, nem uma coisa nem outra há de ficar (OC, vol. I, p. 273-4, grifos meus).

Convivem aí, no trecho, tanto a denúncia dos limites da crítica, que precisa se expandir para que não se torne conservadora e mesquinha, quanto a crença na força da arte, na formação da tradição por meio do que de "melhor" há de surgir.

O uso da palavra "veríssimos" é uma crítica tanto a José Veríssimo quanto aos demais críticos naturalistas, entretanto é a aquele que, sem dúvida, Nestor Vítor se volta mais acirradamente, de maneira que, em 1919, no artigo a Ronald de Carvalho que já venho citando, surge uma frase que parece fazer ecoar essa de 19 anos antes: "José Veríssimo, a propósito de seus Últimos Sonetos, quando estes vieram em livro, fez amende honorable, tanto quanto, para ressalvar a sua decência, podia fazer" (OC, vol. II, p. 170).

No artigo de dezembro de 1919, ainda há outras considerações a José Veríssimo que, avaliado ao lado dos outros dois críticos da geração de 1870, acaba recebendo mais qualificações: é considerado o mais "literato", mas também "pouco alado", com juízos "apoucados", talvez pouco "patriótico" e com muitos "preconceitos". O perfil esboçado por Nestor Vítor, de "polidez habitual”, é, no fundo, bastante irônico:

José Veríssimo já não se revela assim na sua História da Literatura Brasileira. Vê-se claramente, escrevendo-a, tem o intuito de ser como, aliás com razão, ele julga que João Francisco Lisboa foi: “... um dos nossos primeiros europeus, pelas lúcidas qualidades do seu claro gênio, tento da civilização e desdém dos nossos parvoinhos preconceitos nativistas e ainda "patrióticos"'. João Lisboa foi um dos seus modelos mais queridos. Por isso, continuando a tratar de Gregório de Matos, para que saibam que ele não é ignorante, Veríssimo denuncia o poeta como 'servil imitador' do espanhol Quevedo, tal qual, na metrópole, o foram um caterva de versejadores, que cita, todos coevos do terrível satírico.

Havia também no nosso considerável crítico a digna ambição de ser o contrário do que lhe parece que Tobias Barreto foi: um 'mestiço impulsivo e malcriado'. Veríssimo propôs-se a ser o "honnête homme consoante La Rochefoucauld". Repetia em conversa muitas vezes aquela sentença do grande francês: 'Diseur de bon môt, mauvais caractère'. Daí, desde logo, sua falta de simpatia pelo boêmio baiano do século XVII. Havia de causar-lhe por força repugnância o 'sátiro extremamente caroável de mulatas e crioulas' que “prodigalizou-se em versos amantéticos, babosos, de velho femeeiro, a esse tipo feminino, de que a Bahia teve sempre a primazia" (OC, vol. II, p. 164). 
Poderia ainda elencar outros artigos e estudos de Nestor Vítor em que as referências a José Veríssimo ou à Revista Brasileira (em sua terceira fase), dirigida por este, são irônicas ou pejorativas; creio que, no entanto, o que foi exposto permite ter um panorama da visão de Vítor sobre os críticos e a crítica da Geração de 1870, revelando, ao mesmo tempo, o que ele próprio considerava a parcialidade nesses escritores.

Com um olhar, penso, bastante moderno, Nestor Vítor pôde encarar os críticos de sua época, relativizando a própria crítica enquanto atividade intelectual que não excluía a parcialidade.

Mesmo que Veríssimo tenha se oposto abertamente ao modelo naturalista na última fase de sua carreira como aponta João Alexandre Barbosa em A tradição do impasse ou tenha havido originalidade na apreensão das teorias europeias tanto em Romero quanto em Araripe Jr, como apontam, respectivamente, Antonio Candido e Alfredo Bosi, o fato é que a crítica literária do período esteve eivada de preconceitos, de tomadas de posição, de preferências pessoais e das próprias concepções naturalistas, com sua perspectiva étnica e mesológica que prejudicou a leitura do simbolismo.

A recusa consciente, entretanto, do modelo naturalista de crítica não eximiu o próprio Nestor Vítor de utilizar esse modelo para suas apreciações, como se vê, por exemplo, no estudo "Correia Garção" de 1902, publicado em A crítica de Ontem, em que Vítor recorre muitas vezes explicitamente ao determinismo da raça (a "raça latina" e o caráter do "povo português") para explicar a produção poética do escritor do século XVIII.

Aliás, por exercício de coerência em sua obra, Vítor manteve durante toda a sua produção a crítica ao modelo naturalista ainda que, como já disse, fosse o modelo dominante na formação social de que ele participou e, em virtude de tal formação, aparecessem rastros desse modelo ao longo de toda a sua obra em noções como: o "tipo representativo" do momento, os "escritores centrais", as condições do "meio", o caráter "étnico" do brasileiro, etc.

A oscilação, assim, de uma crítica impressionista, predominante, como creio, em sua obra, com a utilização de conceitos e formas de avaliação do modelo naturalista de crítica evidenciam apenas o quadro histórico em que se insere o crítico.

Os críticos da época que mais avançaram em questões estéticas, relativas à técnica ou arte literária, foram aqueles, como Veríssimo, Araripe e Nestor Vítor, que procuraram superar as limitações do modelo naturalista. (...) Essa concepção estética se liga às necessidades de legitimação da atividade crítica e literária e de 
definição do seu status ante as instituições, que levaram à criação da Academia Brasileira de Letras em 1897 (VENTURA, 1993, p. 161).

Não "voluntariamente", os críticos da época foram exigidos a atender a demanda do campo literário, imiscuído, pela pouca diferenciação das atividades intelectuais, com os demais campos culturais, como os saberes da filosofia, da história e da sociologia, e mesmo com outros campos, como o propriamente político (participação nas campanhas presidenciais, eleição nos Estados, etc.). A aproximação a concepções mais estéticas, ou mais "voluntariamente imparciais", trazia em seu bojo a busca por autonomia do campo literário, ao mesmo tempo que a constituição desta dependia da diversificação das produções escritas, da ampliação do mercado editorial, do maior consumo dos bens culturais pelos setores médios da sociedade, o que só seria alcançado após a década de 30, portanto, após a morte de Nestor Vítor.

\begin{abstract}
O modelo naturalista, dominante de 1870 a 1910 na crítica literária e na história social brasileira, foi depois substituído por concepções específicas, que levaram à formação de métodos e teorias próprios a cada uma das disciplinas. Em uma estrutura social de complexidade crescente, dá-se a tendência à especialização dos saberes, o que tornou impraticável o predomínio de modelos universais, como o cientificismo naturalista, sobretudo após a criação dos cursos superiores de letras e ciências sociais na década de 30. A institucionalização da suposta autonomia da literatura e a diferenciação progressiva das disciplinas científicas levaram, mais tarde, ao programa de uma história literária autônoma ou relativamente autônoma (ibidem, p. 161).
\end{abstract}

Sem autonomia relativa, o campo literário era penetrado por demandas, valores, interesses que pouco tinham de "literários". Nestor Vítor, como afirmei, por sua posição original no campo, acabou por compreender em certa medida a política que subsistia nas relações literárias, isto é, a importância de um capital de relações pessoais. Às vezes, de forma consciente, explícita, denunciava, por meio de sua crítica, essas relações e os sucessos e os fracassos que advinham delas para a carreira dos literatos; outras vezes, sem perceber, fazia as mesmas concessões aos poderes exteriores e aos demais campos sociais, capitulando a uma crítica pessoal, apaixonada, de "igrejinha", na qual as impressões de fundo romântico, o valor nacional das produções, a influência "simbolista" e as características do meio ambiente se misturavam.

De forma mais detalhada, na próxima seção, apresentarei a assunção da expressão "política literária", os contextos de uso na crítica de Nestor Vítor e como ela serviu para revelar as relações extraliterárias tão importantes na República Velha. 


\subsection{A expressão "política literária"}

A introdução ao livro de Silveira Neto, Luar de Inverno, apresentada na seção anterior, pertence ao que tenho chamado da primeira fase da produção crítica de Nestor Vítor. Nela, ao lado de certa consciência das relações extraliterárias e dos critérios não "estéticos" que dominavam a crítica, há uma concepção essencialista da arte, expressa em letra maiúscula como a "Arte", como aparece no estudo Cruz e Sousa, escrito em 1896.

Para isso a Arte, como sempre, terá a força de uma sugestão. Mas é o que basta. E os artistas da têmpera delicada e superior de Cruz e Sousa atuarão apenas nas camadas que estejam mais na periferia, desde que a esta demos uma acepção nobilitante.

(...)

A Arte eterna, a simples Arte, é una e indivisível, embora em cada artista se manifeste por uma nova nota, em cada época por diversa expressão. Ela, apesar disso, resiste e resistirá em todos os tempos, impoluta e íntegra, sem que os Bárbaros consigam profaná-la ou fazer de seus destroços retalhos para flâmulas de sangue (OC, vol. I, p. 14).

Essa concepção e essa forma elevada de considerar a arte e o movimento simbolista permanecem fortes nos textos produzidos entre 1896 a 1902, quando Nestor Vítor parte para Paris, conformando o que tenho denominado primeira fase da sua crítica.

Entretanto, como se pode ver no trecho acima, as disputas para legitimar o texto simbolista, legitimar essa "Arte”, já aparecem sob forma figurada ("os Bárbaros"), indicando uma consciência primitiva do confronto para estabelecer a tradição e o cânone literários.

A estada de Vítor por três anos na França, quando pôde ver o enfraquecimento da estética que defendia, bem como o regresso ao Rio de Janeiro, que já vivia a belle époque, vão enfraquecer as noções da "arte pura" e a ilusão de um "futuro glorioso" para o simbolismo, permitindo assim uma maior abertura para os referenciais brasileiros ${ }^{23}$, para o que se produzia no Brasil e como se produzia, o que vai impactar nos seus textos a partir da Grande Guerra de 1914, período que se estende até o final de sua carreira, quando os critérios de nacionalidade, o resgaste da tradição romântica e a legitimação da corrente espiritualista aparecem com maior força.

23 Allan Silveira, cuja tese de doutorado tenho citado, avalia essa mudança nos seguintes termos: "Agora que Nestor Vítor desloca-se para a Europa, as referências de seus textos sofrem um grande crescimento de referenciais brasileiros. Como se o deslocar-se para a terra de onde sofria a maior influência no começo de sua carreira tivesse permitido ao crítico olhar para o outro lado, tornasse-o capaz de voltar sua atenção para as questões brasileiras" (SILVEIRA, 2011, p. 86). 
Sem querer periodizar de forma rígida a obra do crítico, o que quero apontar é que, nessa primeira etapa em que aparece a introdução ao livro Luar de Inverno, de cujo trecho extrai, na seção anterior, a consideração de Nestor Vítor sobre a crítica de José Veríssimo, há uma percepção do embate com a crítica literária oficial, mas uma percepção ainda muito vaga.

A consciência primeira das disputas no meio intelectual se processam ainda em esfera metafórica. A nomeação dessas disputas por meio de um sistema de relações como o manifesto na expressão "política literária” ocorre apenas na fase de consagração de Nestor Vítor. Os juízos que observei nas cartas de 1919 refletem já um plano menos vago e mais realista do confronto social por legitimação no campo cultural.

Nesse sentido, a expressão "política literária" que utilizo no presente capítulo aparece textualmente apenas a partir de 1915, conquanto ela possa ser usada para pensar as lutas desde 1896, em seu primeiro texto de crítica.

Com efeito, é em Três romancistas do Norte, conferência realizada em 30 de outubro de 1915 na série da Biblioteca Nacional sob o título 'Perfis de escritores nacionais', publicada sob a forma de livro em 1916, que aparecem duas vezes a expressão.

O contexto de aparição já é bastante curioso. Como indiquei no primeiro capítulo, na seção “Civilização e mundanismo nos primeiros anos do século XX”, Nestor Vítor, apesar de ser um ferrenho opositor do mundanismo da belle époque, acaba participando desse meio.

As conferências, moda no período, serviam para a propaganda dos literatos, aumentando a circulação dos escritores no meio carioca. Embora a sua conferência tivesse como objetivo principal apresentar a obra de três $\operatorname{romancistas}^{24}$ do nordeste brasileiro, implicando assim o reclame dos escritores, ele aproveita para esboçar um panorama da vida cultural no Rio de Janeiro.

Vítor começa o artigo buscando mapear os possíveis locais e sujeitos de leitura dos "romancistas do Norte". Avalia que no país o intercâmbio de ideias é muito pobre e que "as vias de comunicação para as relações de ordem intelectual são muito mais deficientes, mais cheias de hiatos e de vícios do que os caminhos marítimos e terrestres para as comunicações de comércio e de indústria" (OC, vol. I, p. 170). A partir daí, tece um dos trechos mais realistas e irônicos que se poderia traçar da vida literária da belle époque carioca. É, no interior desse trecho, que aparece pela primeira vez a expressão "política literária", sintetizando toda a descrição das relações extraliterárias que o "homem de letras" deveria 
estabelecer para se conectar ao mundo civilizado. A extensão do trecho justifica-se pela riqueza de detalhes que a sua leitura nos proporciona.

\begin{abstract}
A culpa está principalmente no Rio. O Rio é o centro para que se voltam todas as atenções nesse como em tantos outros sentidos. Mas ao intelectual do Rio o tempo é pouco para cuidar de si mesmo.

Primeiro precisa viver. E hoje ele não é boêmio como foi noutros tempos. Quer vestir bem, quer casar-se bem, quer aboletar-se bem.

O momento não lhe é para isso muito desfavorável. Entre os tipos de mais eminente destaque social muitos há que já se honram na sua companhia, e até já querem ser ou passar por homens de letras também. As próprias mulheres começam a sentir-se atraídas pelos literatos a seu turno: não raras até já se vão aliteratando mais ou menos.

De tudo isso resulta a vida de salão para os nossos intelectuais, que até há pouco quase que não a conheciam. Eles hoje dançam o to-step, o one-step, la matchiche $\mathrm{e}$ outras danças modernas às vezes com a perfeição dos melhores dançarinos. Quando não dançam, dizem versos e ouvem música, de que se vão tornando até bons críticos. Compreendem desde Wagner até Debussy.

As visitas que o literato faz aos salões lhe são generosamente pagas pelas cheias à cunha que vários deles obtém da nata social feminina e masculina, quando realizam suas conferências ou seus mais complexos festivais artístico-literários. Até quem vos fala, apesar de tão pouco mundano e tão canhestro, já os realizou, e pode envaidecidamente dizer que com bom êxito.

Não são apenas os salões familiares e de conferências que tomam tanto tempo ao literato carioca hoje em dia. São os salões de pintura, a Academia Brasileira, a recente Sociedade dos Homens de Letras, e com a grande guerra as festas da Liga pelos Aliados, além das outras pelas vítimas da Seca ou dos jagunços do Sul, os cinemas, os teatros, os piqueniques, os casamentos, as casas de chá.

Mas, além de tudo isto, há o terrível ganha-pão, - a sala do jornal ou o emprego público sob qualquer modalidade, - as visitas de imediato interesse, as cartas, cartões, telegramas e pneumáticos, os enterros, as missas, as entrevistas, as trepações literárias por política literária nas livrarias ou nos cafés. Há os artigos de encomenda para abrilhantar as revistas e os jornais, aquelas de ordinário nos sábados, estas nos domingos, há as poses nos fotógrafos para os clichês dos jornais e hebdomadários. Há que frequentar as redações ainda que se não seja daquela vida. E nesta vertigem tem-se de fazer face às brigas, quase sempre por letras ou por amores, às intrigas no ofício, aos combates a pistolão nos corredores das Secretarias (OC, vol. II, p. 170-1).
\end{abstract}

Temos aqui um bom retrato da importância da vida literária suplantando a "literatura", conforme avaliaria Brito Broca em estudo já citado e um bom mapa do contexto cultural e do campo literário no período em que Nestor Vítor floresceria como crítico e receberia maiores atenções do público. Em cada um dos parágrafos, sob a aparente descrição da vida "penosa" dos intelectuais cariocas, há uma crítica ao universo cultural do momento.

No primeiro, a crítica recai sobre o Rio de Janeiro que monopoliza a vida cultural da República, mesmo sem o merecer. Em outro artigo, de março de 1920, de resenha crítica sobre a monografia de Andrade Muricy, Emiliano Perneta, Vítor volta a atacar o Rio: "que tem uma imprensa capaz de levar aos quatro cantos do Brasil o nome de um autor qualquer" e 
que acaba obrigando os escritores de fora a "obter as boas graças dos literatos e dos jornalistas, que residem aí", porque, afinal, no Rio de Janeiro da belle époque "poetas, dos melhores, que prosadores, dos mais bem dotados, mesmo entre os que residem aí, veem-se quase que obscurecidos pela nuvem de gafanhotos literários que, salvo as devidas exceções, apoderaram-se das revistas mundanas, das folhas que vivem mais de expediente do que por contarem com elementos da vida própria (...)" (OC, vol. II, p. 180-1).

Do segundo ao quinto parágrafos, aponta a entrega do "homem de letras" ao universo burguês, à necessidade de ascensão social que o momento propicia. A vida nos "salões" é criticada em vários estudos: nos textos que tratam das homenagens que parnasianos e naturalistas recebem ${ }^{25}$; no estudo sobre Matias Aires ${ }^{26}$, de 1915, em que aparece de relance ao comparar os gostos dos homens do passado e os "modernos"; em artigo sobre o poeta Hermes Fontes $^{27}$, de 1913; e em artigo sobre Gilka Machado ${ }^{28}$, de 1928. Em todos, apontando a necessidade que os literatos têm de se fazerem presentes nas rodas oficiais da cultura burguesa do período para serem notados e lidos.

No sexto, mostra a diversidade de atividades culturais que, sob o pretexto de causas nobres, como a luta em favor dos Aliados na Guerra, reúne todos os que querem "aboletarse". A referência à Academia Brasileira de Letras é sempre irônica. Já em artigo de 1912, “A Academia Anarquizada"29, Nestor Vítor pôde tecer críticas abertas às escolhas dos "imortais". Era o ano de escolha do ilustre Dr. Osvaldo Cruz, que não tinha nenhuma relação com o mundo literário, mas que, a exemplo do também não literato Lauro Müller, seria eleito em 1912 para ocupar umas das cadeiras da Academia Brasileira.

O último parágrafo é o que mais flagra a vida literária vista na miudeza. O emprego público ou de jornalista profissional ou "de aluguel” aparece como o ganha-pão miserável a que todos, apesar das aparências, precisam se curvar. Em um estudo publicado na revista Terra do Sol, entre julho e setembro de 1924, sobre Rocha Pombo ${ }^{30}$, Nestor Vítor explicita duramente as relações sociais que predominavam nos grupos intelectuais:

25 Como as que alude nos textos "Olavo Bilac", de 1902, e, sobretudo, "A Festa a Coelho Neto", de 1913, ambos recolhidos em A Crítica de Ontem, em OC, vol. I, p. 302-7 e 446-9, respectivamente.

26 Estudo reunido sob o mesmo nome em OC, vol. II, p. 41-58.

27 Artigo homônimo coletado em $A$ crítica de ontem, presente em OC, vol. I, p. 449-60.

28 Artigo homônimo reunido na obra póstuma $O s$ de hoje, presente em OC, vol. III, p. 320-4.

29 Artigo homônimo coletado em $A$ crítica de ontem, presente em OC, vol. I, p. 442-6.

30 Trata-se do texto "Rocha Pombo no Paraná", em OC, vol. III, p. 58-72. 
No Brasil geralmente faz-se jornalista quem não pode, sequer, ser burocrata. A burocracia é o golfão para onde afluem, sobretudo, as aptidões medianas que optam pela segurança inglória, não confiando nas carreiras em que o risco é condição essencial. Mas o jornalismo é a porta que se abre, de ordinário, como um alçapão traiçoeiro e vindicativo, para os irrequietos e imponderados, para os quase sempre falsos, mas presunçosos valores (OC, vol. III, p. 60).

Observando a realidade mesquinha em torno, Nestor Vítor busca se apartar dela por meio dessa consciência que descreve e ironiza as situações. Não fala, no entanto, de fora do quadro social, mas participando dele quando realiza as conferências como essa sobre os escritores do "norte", contribuindo para os jornais e as revistas, convivendo com os tipos que transitam entre as reuniões da Academia Brasileira de Letras e as da Liga pelos Aliados, por exemplo.

A política literária que já era sentida nas análises do campo cultural desde 1896 aparece aqui, em 1915, nomeada, destrinchada, como realidade e como noção para apreensão da realidade. Ainda nesse texto, ao tratar de Xavier Marques, coloca lado a lado as questões da fatura da obra e as da política literária. Na reunião de ambas, a política literária parece se sobrepor:

\footnotetext{
Se ele encarasse as coisas por um prisma mais seu, de cor mais definida, como acontecia com Alencar, ou ainda se tivesse uma filosofia superior como tem, mas menos neutra, marcada com mais cunho próprio, como se dava com Machado de Assis, ainda maior fora o seu mérito e mais possibilidade ele tivera de impor-se ainda em vida a um círculo de admiradores menos restrito do que os que tem hoje, embora contra si persistisse a grave circunstância de não poder fazer política literária, achando-se distante do Rio (OC, vol. I, p. 181, grifos meus).
}

Em outras palavras, se Xavier Marques alcançasse estar próximo de autores já canonizados por seu estilo, por sua "filosofia", ainda assim haveria a "grave circunstância de não fazer política literária”. Estar no Rio de Janeiro e estabelecer contato com os círculos corretos (políticos, inclusive) e com os meios de reclame, de propaganda, eram essenciais para ampliar os admiradores e, sem dúvida, a crítica e a possibilidade de canonização.

A expressão ainda aparece outras duas vezes, ambas no livro póstumo Os de hoje, no artigo "Um pouco de crônica literária", de 18 de setembro de 1921, e no já citado "Gilca Machado", de 08 de julho de 1928.

No primeiro, Vítor trata das manifestações literárias que têm ocorrido no Rio e pareciam demonstrar "mudanças nos ventos", porque a primeira manifestação do ano era realizada em homenagem ao poeta Emiliano Perneta, recentemente falecido, sendo presidida 
por Alberto de Oliveira e outros acadêmicos, mas sustentada pelos "novos" de então como Tasso da Silveira ou Bueno Monteiro. Seguiam-se a essa manifestação literária as vesperais da Biblioteca Nacional, que "mereceram a simpatia de todos" por "não se fazer política literária na escolha das individualidades que sejam relembradas ali. $\mathrm{Na}$ segunda celebraram-se os nomes e leram-se páginas de Adolfo Caminha, naturalista, B. Lopes e Mário Pederneiras, simbolistas, Augusto dos Anjos, realista (...)” (OC, vol. II, p. 451).

No segundo artigo, ao falar que Gilka Machado é pouco comentada pelos críticos ou nas rodas esnobes, relaciona a política literária aos negócios da imprensa:

\begin{abstract}
Acontece com ela o que ocorre com Cruz e Souza. É raro que o nome deste, como o da autora de Cristais partidos, figure no programa de qualquer declamadora, mesmo da Sra. Bertha Singerman, que anda aí ganhando dinheiro a rodo em teatro para maravilhar seu público com a arte superior de emprestar vida a quanta queira, ainda a cousas insignificantes ou secundárias que sejam, em nossa poesia. Não o faz por falta de gosto, estou certo. Faz por negócio. Faz para lisonjear o paladar dos esnobes e das esnobinas que constituem a maioria da sua plateia, aos quais mesmo Bilac, mesmo Alberto de Oliveira, se ela os aproveita, são ainda mal compreensíveis. Faz por política literária, para andar bem com os poetastros que ora dispõem das revistas e vários dos jornais, seus maiores turiferários (OC, vol. II, p. 320-1, grifos meus).
\end{abstract}

Ao mesmo tempo que a "política literária" revela as escolhas, nessa acepção, ela é o sistema de relações que dá visibilidade aos escritores, possibilitando o aumento do público, a ascensão na hierarquia sociocultural. Como noção, a expressão pode ser utilizada para interpretar os mecanismos de legitimação da crítica e do cânone literários, para pensar as lutas no campo cultural. Utilizando-a, pretendo a seguir analisar um conjunto de textos de Nestor Vítor, de 1896 a 1930, de modo a dar um panorama de sua produção para a compreensão do período.

\title{
2.3. Política literária de 1896 a 1930
}

\subsubsection{A monografia Cruz e Sousa}

Publicada originalmente em 1899, a monografia Cruz e Sousa teria sido escrita em 1896 conforme indicações do próprio Nestor Vítor no prefácio de apresentação ao texto. Como afirmei no primeiro capítulo, a publicação dessa monografia objetivava lançar o livro Evocações, fortalecendo-o por meio de uma crítica mais abrangente do que a que Cruz e Sousa havia recebido quando da publicação de Missal e Broquéis, em 1893. 
A tarefa de produzir crítica sobre o poeta e o movimento dos "novos" 31 afigurava-se a Nestor Vítor como uma necessidade em virtude da recepção que os primeiros livros de Cruz e Sousa receberam.

Com exceção do já conhecido naturalista Adolfo Caminha em cujas Cartas Literárias tecera um bom elogio à arte do poeta, o que então se publicara havia sido bastante desfavorável quanto ao caráter "renovador" dos primeiros livros simbolistas ${ }^{32}$.

Tanto Araripe Júnior que vinha escrevendo sobre o "decadismo" desde fins dos anos 80 do século XIX ${ }^{33}$, e que, em 1894, escreve diretamente sobre o simbolismo e sobre Cruz e Sousa $^{34}$ quanto José Veríssimo que escreve, em $1896^{35}$, sobre o romance pretensamente simbolista de Afonso Celso e aproveita para discorrer sobre os dois livros de 1893, Missal e Broquéis, expressam uma visão bastante depreciativa da obra do poeta simbolista.

Tanto um quanto o outro manifestam igualmente preconceitos raciais, correntes na época, e julgamentos bastante negativos quanto à possibilidade de haver "arte" na poesia simbolista em nossas terras. Veríssimo chega mesmo a desqualificar a crítica positiva de Adolfo Caminha, mostrando a incoerência de um movimento que nascia apoiado sob a autoridade de um "naturalista", contrariando assim o espírito europeu do movimento.

A monografia Cruz e Sousa traz, portanto, as marcas dessas oposições que haviam no interior do campo literário e, conforme indiquei no primeiro capítulo, traziam o clima combatente que não podia ser isolado das manifestações sociopolíticas mais amplas que conformavam os primeiros anos da República.

31 Os "novos" era o título que os próprios artistas simbolistas se deram em confronto com os parnasianos, já estabelecidos. A "fundação oficial" parece datar de 1891 quando, no jornal Folha Popular, o grupo constituído por B. Lopes, Oscar Rosas, Cruz e Sousa e Emiliano Perneta lançou um manifesto renovador, a partir do qual seriam conhecidos como os "novos". Conferir Nota Editorial de Afrânio Coutinho para Obra Completa de Cruz e Sousa, organizada por Andrade Muricy.

32 Sem me estender sobre a recepção dos livros de Cruz e Sousa, gostaria de citar o artigo de Simões Júnior (2013) "Fantos, Broquéis e a poesia nova de 1893" que faz um apanhado dos comentários críticos que Broquéis recebeu nos jornais quando do seu lançamento, apontando que o suposto caráter parnasiano do livro é o que se destacou entre os comentários sobre a obra.

33 Entre dezembro de 1888 e fevereiro de 1889 sob o título "Raul Pompéia/O Ateneu e o romance psicológico", Araripe começa a se aproximar das definições do impressionismo, decadismo e simbolismo em arte. Conferir Araripe Júnior. Obra Crítica de Araripe Júnior. Rio de Janeiro: Fundação Casa de Rui Barbosa, 1960, p. 125178.

34 O capítulo "Movimento literário do ano de 1893" do volume III da Obra Crítica de Araripe Jr. (1963) reúne artigos escritos para as colunas da Revista Semana durante o ano de 1894. Foram reunidos em livro em 1896, com a seguinte "Advertência" do próprio autor: "Reproduzindo em livro o que foi então publicado como simples retrospecto de um período literário, (...) pretendo apenas assinalar, em documento mais acessível aos estudiosos, que nós brasileiros não ficamos indiferentes diante do movimento dos grandes centros civilizados" (ARARIPE, 1963, p. 103).

35 Estudo publicado em Estudos de Literatura Brasileira, Primeira Série (1895-1898). Rio-Paris: Editora Garnier, 1901, p. 77-105. 
Nesse sentido, a luta figurada no texto de Vítor assume um caráter mais concreto do que a defesa abstrata de uma "Religião da Arte" como aparece em sua superfície. A República nascente trouxe em seu interior a crença cientificista como modelo dominante de interpretação da realidade. É contra esse modelo que Nestor Vítor se insurge, como o poeta de "O Emparedado" "36. Poema sobre o qual nosso crítico também comenta e a partir do qual ele estabelece um diálogo explícito com a compreensão corrente que se fazia do discurso científico. Vejamos dois trechos deste diálogo.

\begin{abstract}
Se nós reconhecemos que só as asas de um espírito relativamente grosseiro, aparadas pela tesoura de uma estreita Ciência, puderam levar a convicção errada a esse respeito de que o voo para as alturas do Ideal era uma pretensão inepta e primitiva, de que fazer Arte devia ser simplesmente bicar as imundícies da Terra e elevá-las apenas à altura do pescoço; por outro lado vemos que, em todo caso, se se pode voar, não se deve sair da Natureza palpitante e gemente, da Natureza que clama por nós, para que a contemplemos com toda a nossa alma, e amemo-la, e comunguemos espiritualmente com ela, para, nessa glória incomparável, no entusiasmo sagrado que nos desperta essa felicidade de anjos, tartamudearmos, ou pelo menos termos a concepção do desejo de balbuciar a estranha epopeia do Ignoto (OC, vol. I, p. 15).
\end{abstract}

E o segundo extrato:

Certamente que haverá na biologia e na sociologia dos povos algumas leis que sejam particularmente características de cada um, e a essas o extraordinário artista estará sujeito no seu círculo, como nós estamos sujeitos às nossas no nosso. Mas quererem partir do princípio da comum inferioridade africana atual para preconcebidamente anular a individualidade deste glorioso representante da raça maldita, em frente de seus livros, é uma tal futilidade asinina que a mais estreia ciência qualificaria de irrisória, é o mesmo que se quisessem negar a existência das auroras boreais porque tais fenômenos não se passam em todos os meridianos do mundo (ibidem, p. 21).

Sem romper completamente com o modelo dominante de pensamento, a posição de Vítor é a dos que apresentam uma prática de leitura alternativa à que era dominante. Vemos, por exemplo, que, no primeiro extrato, não há a defesa de uma completa ruptura da ligação entre arte e natureza, o que há é uma crítica ao modo pelo qual, "aparadas pela tesoura de uma estreita Ciência", estabelece-se a relação: a arte naturalista "bicava" as imundícies da terra e levava-as à "altura do pescoço", sem "voar"; a arte, no entanto, pode e deve voar sem que, com isso, rompa seus laços com a natureza "palpitante e gemente", sem que, com isso, deixe de comunicar a "estranha epopeia do Ignoto". Ainda que os verbos sejam reticentes (tartamudear e balbuciar), eles indicam que a comunicação entre a "Arte" elevada e a

36 Conferir artigo de Alfredo Bosi "Poesia versus Racismo", no qual o crítico avalia o poema como uma espécie de confronto ao discurso "antropológico" dominante do período. 
"Natureza" deva continuar sob outros termos, sob outras formas, que não as dominantes, "baixas" por oposição. Vemos aqui que não se trata, logo, de uma arte incomunicável, de uma arte fechada na "Torre de Marfim".

No segundo extrato, o advérbio "certamente" que abre o parágrafo indica a aceitação mais ou menos consensual das explicações "científicas" que determinam as características de "cada um" e de "nosso círculo" ao lado da argumentação de que leis gerais não prefiguram a existência concreta dos indivíduos e que uma leitura "preconcebida" é mesmo "irrisória" até para a ciência, pois há as exceções e há as particularidades, o que significava, no contexto da época, defender a suspensão dos preconceitos de raça contra a poesia de Cruz e Sousa.

Na representação que Nestor Vítor faz da luta em torno das interpretações “científicas" ou "artísticas" há, nesse momento, a defesa de participação no campo cultural mais amplo a partir de um modo alternativo ${ }^{37}$ de ingresso. Disputando, de fato, a interpretação que se dava em nome da "ciência" no interior da crítica literária oficial, a partir do grupo a que se associara nos primeiros anos da década de 1890.

Por isso, anos mais tarde Vítor pôde chamar de ingênuas as colocações da sua primeira fase de produção crítica, porque, mais do que "ideias", havia nela a materialização de práticas sociais que o tempo havia feito desaparecer.

Quando indiquei, no primeiro capítulo, que a introdução à monografia, escrita em 1896 mas publicada em 1899, representava a consciência da "hora" vivida por Vítor e que, por isso, ele manteria o original do texto, embora modificadas as condições de escrita, pensava justamente no sentido que a crítica incorporava das práticas sociais mais amplas, a materialização dessas práticas no "calor" do momento, e que Vítor quis preservar conservando a forma original.

A monografia era parte de uma prática alternativa, mas que participava da própria estrutura do meio cultural dominante. A crítica que ele produzia ingressava, assim, nas práticas mais amplas da "República das Letras", como estudou Machado Neto em Estrutura Social da República das Letras, indicando que interpretações distintas nasciam das coteries e "igrejinhas" variadas que se multiplicaram nas últimas décadas do século XIX. O próprio Cruz e Sousa teria liderado uma das coteries existentes, o que justificava a defesa de Nestor

37 Penso especificamente no texto de Raymond Williams (2011) "Base e Superestrutura na teoria da cultura marxista" em que o autor expõe a concepção de que, no interior da cultura dominante, podem aparecer práticas alternativas ou opositoras. A diferença estaria, grosso modo, na extensão dessas práticas entre os grupos sociais. A prática alternativa seria um "modo diferente" que não necessariamente se opõe ao existente. É o que vemos quando Nestor Vítor aceita o ponto de vista cientificista, mas o relativiza a partir da exceção que ele considerava exemplar, o caso de Cruz e Sousa. 
Vítor, que, ao mesmo tempo que ratificava o modelo dominante, buscava invalidá-lo no que se referia ao líder do grupo dos "novos" 38 .

Assim como Cruz e Sousa era defendido e "interpretado" por Nestor Vítor, este passa a ser lido por seus contemporâneos a partir da rede de relações que estabeleceu no meio cultural carioca. Simões Júnior, já citado, em outro artigo, "A repercussão nos jornais de livros simbolistas de 1899", revela-nos como a monografia Cruz e Sousa foi vista em três jornais do período, A Notícia, Gazeta de Notícias e Cidade do Rio.

$\mathrm{Na}$ avaliação do estudioso, ainda que a inovação na poesia brasileira fosse "representada pelo movimento simbolista", os parnasianos "continuaram desfrutando do prestígio público e do apoio amplamente favorável da crítica de rodapé" (SIMÕES JÚNIOR, 2009, p. 247).

Em A Notícia, J. dos Santos, pseudônimo de Medeiros e Albuquerque, analisa a monografia Cruz e Sousa, de Nestor Vítor e o livro de poemas Evocações, de Cruz e Sousa. O "crítico de rodapé" inicia sua seção denunciando a suposta "igrejinha" que existia em torno do nome do poeta recentemente morto:

\begin{abstract}
Não é hoje tarefa muito fácil falar de Cruz e Sousa. O seu nome tornou-se para um grupo de escritores novos uma bandeira de combate. O menos que o chamam é gênio! Onde esteja porém a sua genialidade não sei de nenhum que o tenha dito claramente, de um modo ao alcance das inteligências simples e medíocres [sic] do rabiscador destas linhas. (...) (A Notícia, 8 de abril de 1899, p. 2, apud SIMÕES JÚNIOR, 2009, p. 249).
\end{abstract}

Segundo o pesquisador, as palavras de J. dos Santos buscavam refutar o elogio feito ao poeta de Evocações por Luís Guimarães Filho, na Gazeta de Notícias em abril do mesmo ano. J. dos Santos buscava ainda distinguir os grupos que se dividiam a admirar o poeta morto. De um lado, estariam os que foram realmente amigos do poeta e cuja amizade "obscurecera o espírito crítico desse grupo" (SIMÕES JÚNIOR, 2009, p. 249) e, de outro, estariam os que cercavam os admiradores sinceros. Reproduzo abaixo trecho do artigo de Simões Júnior por evidenciar claramente o clima de disputa que se estabelecia então e do qual participava Nestor Vítor com a sua monografia Cruz e Sousa:

O segundo grupo dos admiradores seria daqueles que "na incerteza do rumo que tomar[iam] e tendo o legítimo desejo de aparecer", cercavam os admiradores sinceros "por espírito de coterie, para, elogiando o amigo comum, serem também

38 "Cruz e Sousa chefiava a coterie composta por Carlos D. Fernandes, Tibúrcio de Freitas, Nestor Vítor, Maurício Jubim, Cláudio Toussaint, Saturnino de Meireles e Félix Pacheco, sendo aí o Dante Negro, 'venerado como mestre' e o 'líder natural do grupo"” (MACHADO NETO, 1973, p. 131). 
elogiados...". O terceiro seria constituído pelos "snobs" que fingiam "sempre entender as mais ininteligíveis cousas, para parecerem espíritos de rara elevação". Sua admiração seria, entretanto, "quase sempre desastrada: elogiam de tal modo, que os louvores parecem antes mal disfarçadas troças...". J. dos Santos acusou muitos admiradores de má fé ao declararem compreender Cruz e Sousa (ibidem, p. 249).

Após esse trecho, Simões Júnior reproduz parte do artigo de J. dos Santos que cita textualmente Nestor Vítor:

Se, exatamente, ele era tão cheio de sublimidades, se o penetrar o seu pensamento já era mostrar-se um espírito de élite, estranho e original! E eles, para uso do público, tomaram o partido de asseverar que nada lhes é mais luminosamente claro que os seus trechos mais obscuros. Apenas, se tentam mostrar deveras que o penetraram, são forçados ou a exprimirem se em trechos mais obscuros ainda ou a dizerem-nos, como Nestor Vítor, que as palavras de que ele se serve têm às vezes significações opostas às do uso! Que vezes? Para se reconhecer isso exige-se por acaso uma iniciação? Uma intuição divina? (A Notícia, 8 de abril de 1899, p. 2, apud SIMÕES JÚNIOR, 2009, p. 249, grifos meus)

A crítica ao "espírito de coterie" é interessante porque parte de alguém, Medeiros e Albuquerque, que era o representante da coterie oficial do período, que ajudara a formar a recentíssima Academia Brasileira de Letras. Como Machado Neto afirma muitas vezes, uma coterie era formada para lutar contra outra coterie mais forte.

Outras vezes, era a coterie da anti-coterie, a igrejinha da contestação ao grupo oficial, tal como ocorreu com a igrejinha de Lima Barreto ou a dos simbolistas frequentadores da Garnier.

(...)

Também contestadores das vigências oficiais eram as igrejinhas simbolistas. Brito Broca dá notícia de uma delas que frequentava a Garnier, mas em franca oposição a Machado de Assis, já nume tutelar da Casa. Compunham-na Gustavo Santiago, Rocha Pombo, Mucio Teixeira, Pedro do Couto, Fábio Luz, Curvelo de Mendonça, Nestor Vítor (MACHADO NETO, 1973, p. 131).

De acordo com Simões Filho, o artigo de J. dos Santos provocou a réplica de Luís Guimarães Filho, em 13 de abril, na Gazeta, o qual insinua a falta de sensibilidade e de instrumentos críticos para a leitura da poesia de Cruz e Sousa. Assim, enquanto J. dos Santos apoiava-se implicitamente na leitura já feita por José Veríssimo sobre a falta de sentido da poesia de Cruz e Sousa, Guimarães Filho apoiava-se também indiretamente na leitura de Nestor Vítor, expressa na monografia.

Assim, era, no interior desses grupos "armados", que nosso autor ensaiava sua estreia crítica. O companheiro de "igrejinha", Gustavo Santiago, escreveu "uma série de quatro artigos publicados na Cidade do Rio" também sobre a monografia Cruz e Sousa. 
Tratava-se de um estudo dividido em três partes, sendo que a segunda dividia-se por dois números do jornal. Santiago iniciou seu longo ensaio em 20 de abril (p. 2) afirmando haver conhecido pessoalmente Cruz e Sousa, que era "homem negro, de estatura regular, olhos cismadores, feições doces, atitudes francas e intimoratas". Depois de breves comentários e longas transcrições do estudo de Nestor Vítor, considerou as interpretações da poesia do Dante Negro à luz das teorias raciais vigentes no período. Segundo o crítico, a África, onde se forjara a raça negra, não se constituiria apenas da aridez do Saara, mas apresentaria também regiões temperadas e aprazíveis, o que levou o crítico a concluir que "peca, por esse lado, toda e qualquer argumentação, tendente a provar a inferioridade da chamada raça africana" pela ação deletéria do meio (SIMÕES JÚNIOR, 2009, p. 251).

Veja-se que os trechos reproduzidos do jornal da época por Simões Júnior colocam-se no mesmo ponto de argumentação de Nestor Vítor: assumir a existência da raça negra, oriunda da África, mas alterar a leitura racial e mesológica que se poderia fazer a partir dessa perspectiva. Segundo o estudioso, Gustavo Santiago chega mesmo a duvidar da existência das raças e o faz apontando para os "esclarecimentos últimos" da própria ciência. Gustavo Santiago, pertencendo à "igrejinha" dos emergentes, como Nestor Vítor, visa legitimar a leitura deste em relação ao poeta Cruz e Sousa, antes chefe e agora "bandeira de combate" da coterie dos simbolistas.

Para encerrar essa subseção, gostaria de citar ainda alguns trechos da monografia Cruz e Sousa pela qual, em 1896, em termos metafóricos, impressionistas, Nestor Vítor já indicava a "política literária" que dominava o campo literário do período.

Ao referir-se às questões da "forma", isto é, da linguagem de Cruz e Sousa, adota uma postura avançada: afirma que o uso da língua é sempre original nas mãos de escritores “extraordinários":

(...) Nenhum extraordinário, até hoje, apoderou-se de uma língua que não a fizesse seu instrumento passivo, que não lhe desse a feição própria do gênio dele, desde a construção até a significação das palavras.

Não estou fazendo uma observação original. Ela é hoje em dia corrente nos altos críticos (OC, vol. I, p. 18-9).

Mais à frente, revela que mesmo "nos altos espíritos de mais minuciosa cultura" é possível encontrar "delitos" (problemas gramaticais), mas que desses "delitos" é que "têm vindo aos poucos nobilitações operadas nas línguas modernas”. O que não ocorre com os "medíocres" que sempre se socorrem dos "Larousse", "os clássicos das odaliscas de cuja propriedade fazem monopólio nos seus vastos haréns" (ibidem, p. 19). A crítica que continua metaforicamente parece atingir em cheio os parnasianos, que podem figurar como os "Tartufos intelectuais" da forma perfeita, rejeitando as linguagens específicas como o "argot". 
O argot, esse estábulo que de quando em vez se arma em presepe para receber louros messias de origem misteriosa, que hão de fazer uma volta gloriosa no mundo, esse humilde e simpático colaborador da Arte, para esses Tartufos intelectuais é um prostíbulo, onde todas as crenças espúrias já nascem desvirginadas e indignas (ibidem, p. 19)

Tecendo a crítica pouco a pouco, chega a reunir, assim, por meio de uma linguagem cifrada, os adversários de campo: os parnasianos e os naturalistas.

\footnotetext{
Se é assim no ponto de vista da forma, é assim no ponto de vista da concepção. Tantas vezes eles se consideram os berços de uma ideia, quando só podem ser dignamente o seu féretro.

Isto no caso de muita honestidade, se eles fabricarem seu pasticcios com a fidelidade dos Jaus.

Há uma espécie pior desses homens: são os compra-chicos do Pensamento, são os mercadores de monstros, os criminosos artesãos de teratologias mentais.

Mas uns e outros aceitam-se porque todos precisam uns dos outros para mútuas admirações cômodas e passageiras, para se dizerem adeuzinho com dous dedos no ar, e passarem rapidamente, levados no entrain estonteante da vida fútil, para fazerem os seus zé-pereiras de aldeia, suando e sorrindo por trás das máscaras, nos domingos-gordos da vida.

O que eles não querem são abalos ou cousas aparentemente impossíveis de compreensão (...) (ibidem, p. 20).
}

O retrato que faz das relações entre os "medíocres" da forma (os parnasianos) e os vulgarizadores do pensamento (os naturalistas, "artesãos de teratologias") é perpassado pelo sarcasmo e pela crítica à mundanidade.

Sem dúvida, Nestor Vítor em Cruz e Sousa faz o elogio da "Religião da Arte", manifesta também nos textos literários de Cruz e Sousa, mas o faz inserindo-se em práticas sociais ligadas à polêmicas e às disputas no restrito meio cultural do Rio de Janeiro. Revelando já nesse texto as "mútuas admirações cômodas e passageiras", Vítor prepara o terreno para uma abordagem cada vez mais explícita da política literária que domina o campo literário nesse início de República.

\subsubsection{A etapa "combatente" na primeira parte de A Crítica de Ontem}

Publicada em 1919, mas reunindo textos escritos desde 1898, A Crítica de Ontem é dividida em duas partes, sobre as quais já esbocei algumas palavras no primeiro capítulo.

Segundo o próprio Nestor Vítor, a primeira parte reúne os textos escritos de forma mais apaixonada e que indicam sua fase de combate. Tratá-los-ei em conjunto porque me interesso menos pelas propriedades formais ou "técnicas" da crítica de Nestor Vítor e mais 
pela apreensão das disputas e confrontos no campo literário, vistos por sua perspectiva de crítico secundário ou dominado.

O prefácio do livro indica que os "trabalhos que aí figuram já foram publicados em jornais, revistas, livros ou opúsculos, e esses bastaram para me colocar na situação em que ora me encontro em nosso meio" (OC, vol. I, p. 255). Ou seja, a situação no campo cultural de que participa nosso crítico em 1919 não é o mesmo quando inicia suas atividades e produz os textos críticos do final do século XIX. Um exemplo disso, refletido nas palavras do prefácio é a acolhida que o livro teve em 1919, recebendo comentários e críticas dos principais jornais e revistas da Capital e fora dela.

No levantamento que Rosana Gonçalves (1996) fez sobre $A$ Crítica de Ontem, em sua dissertação de mestrado ${ }^{39}$, há 34 artigos identificados no período. Desses, 17 são artigos em jornais e revistas do Rio de Janeiro, com destaque para os jornais $A$ Época que publicou três artigos, ainda em 1919, e o Jornal do Comércio que publicou dois, um em 1919 e outro em 1920. No Paraná, sairam dez artigos, com destaque para o jornal A República que, em quatro artigos, comentou o livro de Nestor Vítor. Em São Paulo, quatro artigos foram publicados sobre o livro. Os outros três artigos saíram em Salvador, Natal e Juiz de Fora. Entre os comentadores do livro, encontramos literatos e críticos conhecidos como Andrade Muricy, Leônidas Loyola, Murilo Araújo, João Ribeiro, Pereira da Silva, Monteiro Lobato, Clóvis Bevilacqua, Xavier Pinheiro, Lima Barreto, Jackson de Figueiredo, José Oiticica, Luiz da Câmara Cascudo, João do Rio e Almeida Magalhães.

Com apenas algumas ressalvas, como a que Monteiro Lobato faz em a Revista do Brasil sobre o crítico não separar "coisas sem valor de trabalhos de mérito" (GONÇALVES, 1996, p. 105), a apreciação geral é muito positiva, com a recomendação geral de que todos leiam a obra de Nestor Vítor. Almeida Magalhães chega mesmo a afirmar que a crítica literária não morreu com Sílvio Romero, Araripe Júnior e José Veríssimo, pois Vítor “faz crítica em alto estilo" (ibidem, p. 113). João do Rio, escrevendo em O País, defende o livro como "um modelo a ser seguido por críticos que se querem austeros e superiores às vulgaridades tão comuns" (ibidem, p. 113).

Com efeito, a hipótese que levanto é que, no período posterior à Primeira Guerra Mundial, Nestor Vítor alcança um papel de maior destaque no meio intelectual do Rio de

39 Com o título A evolução do pensamento crítico de Nestor Victor n'A Crítica de Ontem, a dissertação apresenta aspectos da biografia do crítico, dos conceitos e concepções encontradas nesse livro e algo da recepção crítica da obra nos jornais do período. 
Janeiro, assumindo assim a voz da crítica legitimada pelas instituições existentes, ainda que sem o mesmo destaque que os críticos do século XIX.

Se, conforme Machado Neto afirma em Estrutura Social da República das Letras, além "das academias, o jornalismo literário foi o responsável por outras vigências-instituição" (MACHADO NETO, 1973, p. 199), essa amostra da repercussão do livro de Nestor Vítor deve indicar que o mesmo ocupava um papel reconhecido nos meios intelectuais, tendo disponível mais capital simbólico do que nos períodos anteriores.

Com a decadência da Academia Brasileira de $\operatorname{Letras}^{40}$, a transformação da Capital pela Reforma Pereira Passos $^{41}$ e a morte dos três grandes críticos da geração de 1870, temos, após a Grande Guerra, um caminho aberto para a legitimação de novas práticas sociais de crítica. Sem dúvida, Nestor Vítor não se eleva ao papel que tiveram os críticos do passado, como se depreende de toda historiografia literária conhecida, entretanto participa dos meios intelectuais em situação mais favorável do que anteriormente. O fato de ser um crítico vindo do século XIX provavelmente também o favoreceu, uma vez que o critério da antiguidade também conta como um capital no meio literário.

A crítica literária, no entanto, enquanto uma instituição social, passava por transformações, seja pelo coroamento do mundanismo jornalístico já referenciado no primeiro capítulo, seja pela difusão da prática crítica em muitos mais escritores do que nos períodos anteriores $^{42}$.

Entretanto, antes de alcançar esse papel no interior do campo, Nestor Vítor esboçara as disputas e a política literária nos textos que compõem a primeira parte de $A$ Crítica de Ontem, de maneira que se explica as próprias ressalvas que ele forja, no prefácio de 1919, para demonstrar o quanto havia de "paixão" e de "ingenuidade" nessas páginas pretéritas. O prefácio era voltado para o público com o qual ele dialogava civilizadamente em fins dos anos de 1910. Nos textos de 1898 a 1902, é ele quem deve demonstrar "civilidade" para alcançar algum público.

40 É Machado Neto quem nos diz que “já em 1928 sua decadência era visível” (Machado Neto, 1973, 198). Antes, em 1925, segundo Antonio Candido em "Literatura e Cultura de 1900 a 1945", a Academia já via o final de seu apogeu.

41 Recordo aqui Broca afirmando que, com a remodelação da cidade, o "Rio começou a perder o caráter semiprovinciano de velha urbe, com a vida centralizada numa pequena área, onde todos se encontravam e todos se conheciam" (BROCA, 1975, p. 8). O que significa compreender que a Rua do Ouvidor e as portas das livrarias deixavam de ser uma instituição de consagração do escritor no meio carioca.

42 Na carta dirigida a Andrade Muricy em razão de seu livro de crítica O suave convívio, de 1922, Nestor Vítor vai assumir que essa é a hora "em que até os poetas e os romancistas fazem crítica no romance e no poema" e, em seguida, vai listar nada menos que 57 autores de "livros de crítica" que apareceram desde o começo do século (OC, vol. II, p. 245). 
Nesse sentido, seria salutar mostrar como o livro anterior, A Hora, de 1901, editado pela Garnier, busca construir um discurso "civilizado" com o qual Vítor pode se confrontar com o campo literário brasileiro afirmando a mesquinhez e os preconceitos do mesmo. Os ensaios que compõem o livro, no entanto, por não explicitarem as marcas das disputas e dos confrontos no meio cultural brasileiro, pois se debruçam apenas sobre escritores estrangeiros, ganharão meu maior interesse ao analisar, no próximo capítulo, a leitura do simbolismo por Nestor Vítor.

Por agora, interessa verificar a visão do crítico sobre o campo literário nesse fim de século. Nesse sentido, passo a comentar dois textos, um de 1898, "Raul Pompeia" e o outro de 1899, “As Procelárias” que explicitam isso.

Sobre Raul Pompéia, temos um artigo escrito em 1898 e um outro de 1906 intitulado “O Ateneu”. Este segundo pertence à segunda parte de A Crítica de Ontem e aparece como um elogio ao livro cuja segunda edição saíra em 1905 em homenagem aos dez anos de morte do escritor. No segundo artigo, as marcas das disputas no campo praticamente inexistem, restam o elogio e a "confiança na raça" por produzir uma obra de "excepcional talento". No primeiro, há, ao lado das considerações sobre $O$ Ateneu, uma perspectiva mais ampla de buscar encarar a obra de Raul Pompéia na qual se incluem as Canções sem Metro e também a sua atividade política, indissociável, na visão de Vítor, da biografia do autor.

$\mathrm{Na}$ apreensão de Vítor, Raul Pompéia era "um desses seres centrais" como o eram também H. Ibsen ou Cruz e Sousa: "a quem não é dado o repouso nunca, porque eles andam na sua perpétua função de ver, de sentir, de procurar compreender (...)” (OC, vol. I, p. 275). Como outros escritores da mesma "linhagem", também trazia uma "organização de herói" que o fazia lutar contra o tempo em que viveu e isso incluía a luta por impor a própria produção literária. Sobre a recepção de $O$ Ateneu assim discorre:

\footnotetext{
Enquanto livros que já hoje sucumbiram, publicados com o seu, levantaram então ruidosa e festiva conclamação em torno, cada pena trazendo-lhes um louvor ao bico, cada ouvidoriano disputando a honra da primazia no folheá-lo, d'O Ateneu, coitado, fundido numa magra, engelhada, implicante edição, que parecia provinciana, matogrossense, nem quase se ouvia falar, senão em rodas muito especialistas, num murmúrio pálido de despeito descoroçoado (ibidem, p. 278).
} 
A descrição da "política literária" que se fazia na fase áurea da Rua do Ouvidor ${ }^{43}$ e que permitia a consagração de textos que logo "sucumbiram" é explicada pelas relações extraliterárias que Raul Pompéia não soube estabelecer bem.

\begin{abstract}
Já então se estava formando, muito timidamente ainda, uma má casta de gente de letras que anda por aí agora de colo mais alçado, numa atitude insolente, divergindo às vezes dos elogios de cartazes.

A explicação é fácil. É que Raul Pompeia era menos sociável, ou antes mesmo adaptável do que esses seus contemporâneos. Aprendera a escrever, mas ficara atrasado na arte de fazer coterie. Ora, esta deve ser complemento daquela, se os termos invertidos não dizem a verdade melhor ainda. Isto de só se contar com o mérito é geralmente ofensivo a quem está empregado em nos julgar. Tem gênio? Guarde para si; o que queremos saber é se é bom rapaz. Bom rapaz, às vezes, significa ter todos os defeitos. Em uma palavra, não presta para nada? É como eu, está aceito o seu livro, por mim e pelo meu público, caro amigo (ibidem, p. 278).
\end{abstract}

Observe-se com que clareza, com que espírito combativo, com que ironia Vítor explicita as regras de funcionamento do campo literário brasileiro: a arte de escrever é inseparável da "arte de fazer coterie" para que se alcance reconhecimento.

Poder-se-ia alegar que a sua interpretação é simplesmente a apreensão de um ressentido, de um autor secundário que, "na sua mediania", lembrando as palavras de Candido, nunca alcançaria de fato a consagração. No entanto, o próprio Nestor Vítor relativiza suas opiniões ao falar da postura de Raul Pompéia e suas ligações com o meio e ao mostrar, sobretudo, que nem sempre o "demérito" vence. Vejamos seu raciocínio:

No entanto, Raul Pompéia não era um provinciano chegado de novo, estranho ao sindicato que monopoliza os negócios literários do momento. Nascido junto ao Rio, educado no Rio, ele relacionara-se pelos colégios, nas academias com a geração que já tinha tomado posições. Visivelmente, pois, o que se dava é que ele não era o mais acariciado entre os seus. Nessa frieza ia até certo ponto uma tácita tentativa de eliminação.

Completemos o julgamento. Uma geração não é só composta de mesquinhos, não é só feita de rebotalhos. Não há ninguém que tenha razão, absoluta razão sobre todos. Por outro lado, nem sempre é o mérito negativo que vence; em última análise até o demérito não vence nunca. (...) E há altas individualidades, legitimamente altas, que puderam vencer desde que deram o primeiro passo (ibidem, p. 278-9).

Em outras palavras, Raul Pompeia soube, por sua posição na sociedade carioca, estabelecer relações com a "geração que já tinha tomado posições". Daí que, mesmo sem estabelecer estritamente coterie, ele estava bem situado no campo, apesar de não "ser

43 Comentada por Machado Neto, a rua do Ouvidor também era uma instituição da "República das Letras": "Falta-nos ainda mencionar as livrarias, os cafés e confeitarias e a própria rua do Ouvidor, estreita ágora mundana e literária onde se faziam e desfaziam os mitos e os prestígios da vida intelectual" (MACHADO NETO, 1973, p. 201). 
acariciado entre os seus". É bom recordar que Araripe Júnior começa escrever de um forma compreensiva sobre o autor e sobre a obra $O$ Ateneu já em dezembro de 1888, evidenciando a posição no campo de Raul Pompeia que, antes de lançar o livro em "magra edição", havia-o publicado como folhetim no importante jornal Gazeta de Notícias.

De outro modo, como afirma Vítor, nem sempre o juízo negativo de "mesquinhos" vence. O próprio campo não é formado por um bloco homogêneo de vozes e, no próprio processo histórico (a partir do "primeiro passo"), é possível às "altas individualidades" vencerem. O que o nosso crítico conclui depois de ainda citar Dante Alighieri e Goethe, mostrando que um e outro tiveram posturas diferentes na produção da obra (Dante mais reservado e Goethe mais entrosado com as altas rodas da nobreza) é que caso "Raul Pompéia tivesse trazido uma natureza análoga à do grande homem da Alemanha, podia ter sido o talento que teve e, no entanto, conseguir fazer claque" (ibidem, p. 279-80).

Ironicamente, Vítor parece legitimar a "política literária", apresentando-a como natural, coextensiva à atividade intelectual em si, afinal, para ele, são "modos de ver, que se expõe, mas que seria imbecil discutir" (ibidem, p. 280). Como se, no fundo, pouco importasse fazer ou não a política literária, participar de uma coterie, o que resta é a esforço do artista diante de uma prática social mais ampla de que o fazer literatura é apenas uma parte.

O texto seguinte, "As procelárias", de 1899, trata da obra homônima de Magalhães Azeredo. Se em "Raul Pompeia" Nestor Vítor indicava o não pertencimento do escritor a uma coterie como um prejuízo, em "As procelárias" ironiza a coterie por excelência do seu período, a da Revista Brasileira, a de Machado de Assis e, por extensão, a de Veríssimo e da Academia Brasileira de Letras.

Magalhães de Azeredo tendo nascido em Portugal e depois indo viver em Itu, no interior de São Paulo, teve a sorte de ser "abençoado" por Machado de Assis, que se tornou o "paraninfo" do jovem escritor no meio intelectual brasileiro. Parnasiano, fundador da cadeira de número 09 da Academia Brasileira de Letras, Azeredo só poderia receber, por esse conjunto de "atributos", a crítica irônica de Nestor Vítor que aproveita para criticar seus adversários do campo.

Este livro, como exercício de escrita de um aluno do Colégio de Itu, seria uma bela produção; vindo do petit Hugo da Revista Brasileira, o que revela é que ele, apesar de já profundamente viajado, ainda se ressente muito de Itu e de seu colégio. Se não me engana, o jovem Sr. Magalhães lá esteve; e, se não esteve, devia estar. Cheira flagrantemente a isso. Seus versos a Nossa Senhora, oferecidos à mamãe, suas prolixas conversas com as musas, suas canções à lua (forma João de Lemos), a 
Camões, a Natércia, etc., a esta hora de Ibsen, de Maeterlinck, de Mallarmé, são perdoáveis apenas num formigão (OC, vol. I, p. 283).

A ironia aqui caminha para o deboche, mas o que objetivava Vítor não era tanto atacar o jovem escritor a quem ele chega a desejar que se revele um "talento definitivamente um dia" quanto defender o "novo" como um traço positivo, condenando assim a estética parnasiana como ultrapassada.

A verdade, porém, é que os sentimentos já sentidos, as expressões já expressas, os clichês dos velhos e dos novos Acácios, venham sob a égide de quem vierem, hão de ser varridos do caminho, porque só o que é significativo, característico, novo, é que propriamente é (ibidem, p. 284, grifo do autor).

A defesa do "novo" não significa, todavia, a defesa do que está na "moda", porque, segundo Vítor, a "moda é tão velha como o arcaico" (ibidem, p. 284). A crítica é sobre o uso do "lugar-comum" como um "passaporte para glória convencional dos chamados ilustres moços de juízo" (ibidem, p. 284). Incide, portanto, sobre as convenções que os jovens assumem para serem imediatamente aceitos, dando assim uma sobrevida aos que seriam os "velhos", fato que indigna o nosso crítico.

\footnotetext{
Pode-se dar que o autor das Procelárias um dia seja alguém, mas já então ele terá aprendido a conhecer o seu tempo, há de tê-lo amado, tê-lo-á representado vivamente. Verá aí que, se é de inferiores procurar a evidência à custa de personificar a futilidade do momento, de tiranizar por três dias como mestre de cerimônias, como Raunier de literaturas passageiras, é mais irrisório ainda, e é criminoso até, trairmos a nossa mocidade amancebando-nos com o cacoete célebre, com as veneráveis almorreimas, impedindo com o nosso prestígio de moços que os resíduos em plena putrefação acabam de fermentar, transformem-se de uma vez, ainda a polvilhá-los de sal, pensando em que eles nos deixem como universais herdeiros nas suas declarações de vaidosos senis (ibidem, p. 284).
}

Aqui o deboche é claro, mas, como disse, dirige-se menos ao poeta e mais ao "cacoete célebre" e às "veneráveis almorreimas". As referências debochadas podem ser ao próprio Machado, conhecido por sua gagueira, e a Veríssimo, diretor da já citada Revista Brasileira (em sua terceira fase), que aparece substantivado em "os veríssimos do tempo" quando Vítor, ainda nesse artigo, faz um paralelo entre a figura de Machado e a de José de Alencar, e entre Castro Alves, apresentado à sociedade literária por este, e Magalhães Azeredo, por aquele.

Terminando o texto, Vítor novamente contrabalanceia o poder das relações extraliterárias, da política literária inserida no momento, com a visão de que o futuro 
restabelece a verdade quanto aos valores dignos, o que se combina bem com a ingenuidade de combatente que se lhe afigurava então.

Se o jovem Sr. Magalhães vier a revelar talento definitivamente um dia, há de aprender a rir de muita coisa, e não há de ver como neste mundo pequenino das pequeninas aparências vamos uns servindo de gato morto aos outros nas mãos das mediocridades espertas, até que um dia iremos todos embora, ficando aqui apenas o que de grande o pigmeu pôde provocar ao gigante, vendo-se então por fim que o logrado em última análise há de ser sempre S. M. o Imbecil (ibidem, p. 285).

Diferente do crítico que se legitima no século XX, Vítor ainda é uma espécie de "nefelibata", acreditando nos poderes transcendentes do futuro para fazer justiça aos realmente "novos" do presente. Daí que o próximo texto que comentarei a seguir é o artigo também de 1899 intitulado "Os Novos", com o qual, de forma ambivalente, Vítor aponta a política literária e seus representantes no momento atual e, ao mesmo tempo, remete para a possibilidade futura de que, dos atuais defensores da Arte pura, dos atuais nefelibatas, possa surgir um grande artista.

De início, Vítor parece fazer coro com a crítica oficial que considerava a maior parte da produção dos estreantes, principalmente, poetas, ruim, própria, portanto, de nefelibatas que acabariam por “impor-nos diagnósticos desesperadores, falando-nos, não da formação de um núcleo intelectual embora que fosse ainda em estado muito de início, mas de um funesto desagregamento por franca degenerescência orgânica" (OC, vol. I, p. 286).

Esse quadro, no entanto, de molde "cientificista", será tomado em sua positividade, considerando "o momento que atravessa a literatura universal" (ibidem, p. 286). Para ele, nomes como Zola, Tolstoi ou Ibsen, embora sejam os grandes nomes de fim de século, foram sempre isolados e tidos como "extravagantes, como degenerescentes" e os artistas menores de hoje em dia só podem derivar desses grandes nomes. Daí que não se pode, preconcebidamente, afastar esses novos escritores com uma posição moral conservadora.

\footnotetext{
A sociedade é como as mulheres: ciosa da ventura do momento, despreocupada com a sorte dos que hão de vir amanhã. Ela sente que estes loucos de hoje preparam alguma coisa grandemente estranha, que há de abalar, quem sabe até onde, tudo quanto está garantido sob a ordem atual. Daí a sua repulsa por eles: ao menos quer ver se consegue adiar (OC, vol. I, p. 289).
}

A atitude "simpática" com os "novos" é a que defende Nestor Vítor. Entende que, de fato, muito do que os "nefelibatas" produzem é ruim. Mas, pensando no fenômeno da influência estrangeira, reconhece que os nossos "copiam" os portugueses, que, por sua vez, 
“copiam" os franceses, sendo todos, de qualquer forma, "produto lógico da época, toda ela oferecendo aos observadores superficiais o aspecto das degenerescências e desorganizações" (ibidem, p. 289).

Aqui fica evidente que a crítica oficial que ele até nomeara no início do artigo (o Sr. José Veríssimo) não poderia observar com profundidade a literatura do momento, pois estava presa a um modelo de análise que só poderia enxergar "evolução" ou "degenerescência"; não poderia perceber o verdadeiro apreço pela "Arte" nesses novos escritores.

\begin{abstract}
Além disso, vindo assim, incompreendidos e ridicularizados, fazendo, portanto, de seus livros inevitáveis refugos no mercado literário, e tornando-se inviáveis no caminho da contemporânea e passageira glória barata, (que só obtêm facilmente os hábeis acomodatícios), elegendo-se a si mesmos os D. Quixotes da pura Arte, esses moços ao menos mostram-se adversos ao triste culto da Musa Venal, trazem consigo a nobreza do desinteresse e trazem a coragem, duplas qualidades sem as quais é impossível ser magnífico e grande.

Eles, afinal de contas, representam nas letras a reação contra este acaturrar sistemático da alma humana, esta corrente bastarda de sofismas que vem nascendo colateralmente com eles e que traz a veleidade de erigir-se em sistema de ideias vencedor, fazendo a desfaçada apologia da Força, lisonjeando-a e justificando-a em toda as suas manifestações odiosas, inferiores, com a bajulação ancestral dos velhos palacianos nas decadências das antigas civilizações (ibidem, p. 289).
\end{abstract}

Como se vê, Vítor faz a denúncia do reduzido mercado literário que não pode absorver os "nefelibatas", cultores da "pura Arte", mas aceita, nas letras, um sistema de ideia que faz "apologia da Força", ou seja, o naturalismo de fundo positivista que vicejou no Brasil do período.

Embora eu vá desenvolver essa ideia no próximo capítulo, a avaliação que aqui faz Nestor Vítor dos "novos" escritores e de seu ideal corresponde a uma imagem bastante positiva, porque participa de uma lógica segunda a qual "quem perde, ganha" ${ }^{44}$, ou seja, a “incompreensão" e o "ridículo" de que são vítimas os cultores da arte pura representaria, em princípio, um valor de outra natureza, simbólico, para os participantes do campo artístico. Obviamente, as "regras da arte" só têm seu pleno funcionamento em um campo já consolidado, o que não é o caso do campo literário brasileiro, mas, como venho afirmando, é

44 Penso novamente na análise de Bourdieu, agora expressa em As regras da arte. Ao analisar as escolhas das personagens do romance $A$ educação sentimental de Flaubert, Bourdieu afirma em determinado ponto sobre o "jogo da arte": "O jogo da arte é, do ponto de vista dos negócios, um jogo de 'quem perde ganha'. Nesse mundo econômico invertido, não se pode conquistar o dinheiro, as honras (...) em suma, todos os símbolos do sucesso mundano, sucesso no mundo e sucesso neste mundo, sem comprometer sua salvação no outro. A lei fundamental desse jogo paradoxal é que aí se tem interesse no desinteresse: o amor pela arte é um amor louco, pelo menos quando o consideramos do ponto de vista das normas do mundo ordinário, 'normal', aquele posto em cena pelo teatro burguês" (BOURDIEU, 1996, p. 37). Ao falar sobre o discurso de Vítor em torno do simbolismo, voltarei a tratar do assunto. 
na perspectiva de constituir a autonomia do campo é que Vítor pôde fazer exigências e denúncias em relação à prática social da crítica do período. Apontando, nesta primeira fase de sua crítica, justamente a existência de valores externos à "pura Arte", ele conduz seu discurso contra e a favor do campo literário em formação.

Daí que ele possa afirmar em seguida que é melhor essa geração de nefelibatas, da qual pode eventualmente surgir um grande nome, do que os moços que vêm muito "comedidos e sensatos", com um modo de ser muito "castiço, muito autorizado, muito tal sim senhor, mas especialmente desfrutável e rococó” (ibidem, p. 291).

Novamente, o que incomoda a Vítor são esses escritores em particular, com a necessidade de serem bem recebidos, bandearem-se para as rodas oficiais da cultura da época, mais uma vez legitimando a continuidade do poder da crítica oficial, expressa em José Veríssimo e na Revista Brasileira. De novo, a crítica ferina ao meio cultural aparece em suas palavras por meio do deboche à oficialidade.

Eu acho detestáveis essas camadas de moços. Antes de tudo, falta-lhes propriamente mocidade; é de moço empreender, é lançar-se, não é vir esgueirando-se pelos beirais, e receber o santo e a senha como uma sorna obediência senil. (...)

E esses que vêm assim são geralmente incuráveis. Quando tiverem mais um pouco de cultura, da tal como a entendem os neo-epicuristas contemporâneos, da que não é mais do que uma zootecnia aplicada ao espírito, jurarão pelo Sr. José Veríssimo, sem dúvida. É gente que se está preparando para dar a sereia apologista dos acadêmicos na Revista Brasileira da $4^{\mathrm{a}}$ época, talvez (ibidem, p. 291, grifo do autor).

Por fim, Vítor desdenha dos moços que, abrindo caminho por meio de política literária, conseguem o sucesso mundano e a consagração das instituições oficiais do campo literário. $\mathrm{O}$ retrato, como antes, mistura o deboche com a ironia na explicitação das relações extraliterárias que conformam o espaço social em que ele se insere.

Entre uns e outros, finalmente, vêm uns poucos jovens Fagerolles do termo-médio, um pouco peixe, um pouco carne, tragicômicos, místico-sensuais, que batem no peito ao falar em Nossa Senhora, mas piscando o olho aos cronistas dos jornais para lhes significarem que é por capadoçagem.

São os que logo hão de ganhar por toda a parte o adjetivo de adoráveis, os que hão de substituir Olavo Bilac e Coelho Neto, quando a estes lhes vier o tédio de serem brilhantes cronistas de jornal. Eles hão de achar meio de empulhar o Sr. Deiró e o Sr. Veríssimo, abrindo-lhes assinaturas à boca pequena, mas impondo-se-lhes ao mesmo tempo, por tal modo que os homens os hão de aceitar, não de proclamá-los, a ponto deste último instar com eles, finalmente, para que sejam candidatos à Academia (ibidem, p. 292). 
Que existam ressentimentos e paixões nas palavras de Vítor, não há por que negar, o que, no entanto, suas caracterizações, avaliações e opiniões revelam é uma dinâmica do mundo literário na capital do país.

Na sua pena, nesse período, não cabe apenas o elogio aos filiados à corrente "místicosimbolista". Ainda na primeira parte de A Crítica de Ontem há um breve mas bastante elogioso artigo sobre o poeta Luís Delfino ${ }^{45}$ que ficara conhecido tanto por sua produção romântica quanto parnasiana e a quem ele chamará respeitosamente de "um Leconte de Liste tropicalizado" (ibidem, p. 292) e um outro artigo, mais longo, dividido em três partes, em que também faz uma crítica elogiosa a Cana $\tilde{a}^{46}$, mesmo sabendo das boas relações que Graça Aranha tinha com toda a oficialidade literária do período, tendo sido, inclusive, um dos fundadores da Academia Brasileira de Letras mesmo sem ter publicado ainda o livro que o consagraria. Entretanto, como parte dessa dinâmica geral, parecia a ele necessário explicitar os mecanismos de integração e de exclusão dos literatos no mercado das letras. Por isso, as referências constantes a Veríssimo, a Academia e a escritores consagrados como Coelho Neto ou Olavo Bilac. Como a voz de um crítico marginalizado, secundário, interessava mostrar as relações sociais que atuavam na consagração dos homens de letras.

Assim, para encerrar a subseção, que conforma o que tenho chamado de primeira fase da produção de Nestor Vítor, farei alguns comentários sobre o artigo de 1902, "Olavo Bilac", também publicado em A Crítica de Ontem, que explicita a política literária como manifestação do próprio meio intelectual canhestro.

Como em outros artigos, há uma referência a José Veríssimo, que "apontou que o traço mais característico de Olavo Bilac era ser o mais correto dentre todos os poetas do Brasil" (OC, vol. I, p. 302). De alguma forma, as várias referenciações ao crítico consagrado não são somente parte de um ataque com o objetivo de deslegitimá-lo diante do público leitor, são talvez e muitas vezes apenas diálogo que se quer "racional" e "público", considerando a ausência de ambiente intelectual mais propício para o desenvolvimento das ideias.

Apoiado em Habermas, Terry Eagleton em A função da crítica demonstra a íntima relação entre o crítico do século XVIII, os “periodistas", e o público leitor. Do mesmo modo, ao tratar da relação entre público, classe e a formação da crítica moderna, Luiz Costa Lima, em Dispersa Demanda, também apoiado em Habermas, aponta, no caso dos países europeus

45 Trata-se do artigo de 1899 "Luís Delfino", publicado originalmente na revista Vera Cruz em razão de festa realizada no Teatro Apolo em homenagem ao poeta. Ver OC, vol. I, p. 292-3.

46 Artigo de 1902 intitulado “Canaã. Romance do Sr. Graça Aranha”. Conferir Vítor, OC, vol. I, p. 293-302. 
em que a burguesia ascendia em confronto com o Ancien régime, uma íntima relação entre a formação do público (burguês) e do crítico de arte que "reflete a opinião de seus pares e, ao mesmo tempo, a orienta e a difunde" (LIMA, 1981, p. 35-6).

No caso do Brasil, Lima afirma que, "muito ao contrário, o pensador não partilhou daquela troca prévia de ideias, não sentiu o vínculo a uma classe, cujo interesse social prefiguraria seu julgamento. É um isolado, que não tem público e cujo êxito antes dependerá da veemência que empreste a suas frases (...)" (ibidem, p. 36).

Por isso afirmo que, mesmo que fizesse parte de uma estratégia de "combate", o diálogo com os demais críticos prefigurava-se como o estabelecimento de uma rede "civilizada" de intercâmbio intelectual. Como disse, o discurso de Vítor atua tanto contra o campo em formação, fazendo-lhe exigências de maior parcialidade e de adoção de critérios mais "estéticos", quanto à favor na medida que prenuncia o estabelecimento de uma crítica mais "reflexiva", logo, mais "voltada", “dobrada" ao próprio campo literário e não a outras demandas exteriores.

Com efeito, e retomando o artigo "Olavo Bilac", o que nosso crítico faz nesse texto é uma análise social bastante acurada do perfil do público leitor do período. Não se trata, em 1902, do auge da belle époque carioca com seu "excesso" de mundanismo, trata-se, na verdade, do retrato de um meio cultural acanhado, de fundo provinciano, que consagra Olavo Bilac. Assim, nas palavras iniciais do artigo, discorda de Veríssimo, afirmando ser a "correção" não a maior qualidade de Bilac, mas o fato de ser o "mais querido dentro todos os nossos artistas do verso (...) a realização mais completa do tipo de poeta que o nosso meio atual pôde assimilar" (OC, vol. I, p. 302-3).

A crítica no artigo, portanto, não incidirá tanto sobre os critérios parciais dos críticos do período, mas sobre a constatação um tanto amarga da mesquinhez do meio. Daí que ele afirme tranquilamente:

\footnotetext{
Estas são coisas que ninguém discute. Não é à toa que uma sociedade, que um povo, que uma raça qualquer cria fé num tipo seu, apaixona-se por ele, e levanta-o. É que esse tipo de qualquer forma corresponde aos ideais dessa coletividade, de qualquer modo representa-a legitimamente. Não são coisas que se possam fabricar por artifícios, ou combater com razões frias e abstratas, sempre incompletas, principalmente quando se trate de artistas (ibidem, p. 304).
}

Em outras palavras, como manifestação social de um tipo de "coletividade", a arte de um escritor não pode se fabricar artificialmente ou se combater friamente. Não importa aí a 
crítica de arte e/ou de literatura. A "fé" e a "representação" que determinado artista alcança reflete a própria sociedade de que ele é uma manifestação mediana.

Nestor Vítor que enumera outros poetas no artigo, Luís Delfino, Cruz e Sousa, Luís Murat, Alberto de Oliveira, Raimundo Correia e B. Lopes, verifica que Bilac não tem par entre eles, justamente porque, diferente deles, não tem características que se sobressaíam, ele representa o "termo médio de nossa capacidade estética".

\begin{abstract}
Bilac não tem voos geniais. Não é caracteristicamente um brâmane abstrato, falando da Natureza e para a Natureza, como que perante a eternidade, sob grande e solene emoção. Não é um meditativo de forma concisa, quase lapidar. Nunca falou em duquesas, e não será na sua obra que se possa encontrar um maior número de frases novas ou de rimas imprevistas. Mas é o mais simples, o de mais seguro bom gosto, o mais humano e o mais natural, - no sentido comum destas duas palavras, - que entre os seus companheiros de época surgiu. No seu livro, - ele só tem um livro de versos até agora, - nada de atormentado se encontra; suas frases são dessas em geral que todo o mundo se julga capaz de fazer. Seus sentimentos, como os de todo o mundo tem: se ele ama, diz-nos que ama, se deseja diz-nos que deseja, se aborrece não oculta seu enfado a ninguém. E ele ama, deseja, aborrece os objetos que geralmente são votados a isso: as mulheres, a natureza, a pátria em que nasceu, o lar em que se criou, os amigos ou inimigos com quem convive ou se cruza. Mas tudo isso de um modo quente, interessante, sob forma correta, em língua tão boa como a que melhor se escreve entre nós. Representa no verso o termo médio da nossa capacidade estética (ibidem, p. 305).
\end{abstract}

Vislumbra-se, a partir dessa visada "sociológica" de Vítor, a perspectiva que, no fundo, a política literária que se pode observar na atuação dos escritores é apenas parte de um quadro social mais amplo, no qual parece não existirem as condições prévias para a consolidação da autonomia do literário e para o desenvolvimento do debate intelectual de posições. É o que também pensa Roncato (1979) ao estudar a obra crítica de Nestor Vítor:

(...) Aliás, este tipo de formação, do ponto de vista sociológico caracteriza os ambientes intelectuais precários, onde o que se entende ser a atividade intelectual está muito mais relacionado a um certo vedetismo, a um tipo de disputa e prestígio pessoais, do que propriamente à tarefa de pensar e fazer a cultura (RONCATO, 1979, p. 35). 
Conforme apresenta Luiz da Costa Lima, sem um público especializado ${ }^{47}$, a crítica só poderia assumir um caráter judicativo e militante e, sem um meio "cultivado", a literatura de maior sucesso só poderia espelhar o precário meio ${ }^{48}$, como Vítor afirma sob a hipotética situação de que Bilac perdesse a "auréola":

(...) se o Brasil subitamente acordasse para um engrandecimento verdadeiramente imprevisto: se ele ganhasse outra cerebração, se se fizesse águia, e brandisse poderosamente, em demanda de altos horizontes, duas grandes asas possantes.

Aí, sem a complexidade necessária para ir tão longe que pudesse continuar a representar a média da capacidade estética da raça, no verso, ele se arriscaria a ficar num segundo plano (ibidem, p. 307).

Por essa perspectiva, de um espaço cultural bastante reduzido, a política literária aparece também como coextensiva às demais práticas sociais. Estabelecer relações "afáveis" com o meio é o que se espera do jornalista, do literato, em suma, do homem de letras do período.

\begin{abstract}
Nunca tomou a peito empresa alguma de verdadeiro vulto, quase nunca se meteu em questões: amigo de todo o mundo, em geral, sem êmulos literários que lhe façam guerra, sem fazer guerra a ninguém. Gosta de assistir às ascensões serenas, às que são feitas sem oposição; entra discretamente quase sempre no número dos que as aplaudem. Às naturezas combatentes ele não lhes é simpático. Se aparecem no horizonte literário de vez em quando algumas dessas, O. Bilac as não guerreia (pelo menos nenhum desses tipos poderá citar sequer uma linha assinada por ele que lhe fosse claramente hostil), mas também não as acoroçoa, o que seria insensato levarlhe a mal (ibidem, p. 306).
\end{abstract}

O debate de ideias, de posições, e o confronto das escolhas, estimulados por Nestor Vítor, por mais paradoxal que possa aparecer, refletem, nesse sentido, muito mais a defesa do "literário", do "estético" do que considerações puramente "literárias", como a que Veríssimo apontou em Bilac e que Vítor buscou desconstruir.

47 “ (...) à opinião pública já constituída na França e na Inglaterra opunha-se, entre nós, um número reduzido de membros da oligarquia, que, na condição de estudantes dos raros cursos superiores, de funcionários ou bacharéis, animavam uma escassa vida intelectual. Embora no ambiente europeu o crítico não tivesse uma função propriamente teórica - daí os impasses que encontramos nos nossos não fossem melhor resolvidos por Taine ou Brunetière - mas antes prático-judicativa, aquela função era paralelamente desenvolvida pela filosofia da arte (haveria algo mais oposto ao sociologismo naturalista com suas discussões sobre a primordialidade do meio ou da raça, do que o anticientificismo de um Ruskin ou as reflexões sobre a arte de um Nietzsche?) e pela crítica marginal de um Baudelaire, de um Mallarmé, de um Flaubert, de um Proust. (...)". Nota do capítulo "A crítica literária na cultura brasileira do século XIX". (LIMA, 1981, p. 54-5).

48 Neste artigo, Vítor dá uma indicação também do público leitor de Bilac: “a rapaziada literata (...) E não são os moços literatos apenas. São também os estudantes (...) É até parte do pessoal mais grave que frequenta essa famosa artéria [a Rua do Ouvidor], - advogados e médicos ainda não encanecidos que acompanham de certo modo o movimento das nossas letras, concorrendo assim para tornar um pouco mais complexa o meio. Entre estes, de vez em quando, um ou outro engenheiro (...)" (OC, vol. I, p. 303). 
Ser uma poesia "correta" é uma adjetivação que poderia ser atribuída à poesia de Alberto de Oliveira, como afirma nosso crítico. O que, de fato, era a poesia de Bilac era ser "querida". A adjetivação que o público, mais do que os críticos culturais, projetavam sobre a obra e a figura do poeta conduz, na argumentação de Vítor, à observação do meio cultural brasileiro, da mediania intelectual de que Bilac era apenas uma expressão "natural" e "tranquila". Que Bilac, como outros literatos, realize a política literária, sendo "amigo de todo mundo", "aplaudindo" as "ascensões serenas", não "guerreando", mas também não "acoroçoando" as "naturezas combatentes", é apenas parte do que ele, de um modo mais geral, consegue representar da sociedade e do seu meio intelectual nesse início do século XX.

\subsubsection{Transição e intervalo entre 1902 a 1910}

No período em que esteve em Paris, de 1902 a 1905, as cartas publicadas nos jornais pouco retratavam as relações literárias no Brasil, dando notícias e fazendo comentários de obras, autores e episódios da vida cultural francesa. Comentarei brevemente, nessa subseção, apenas alguns trechos dessas cartas por fazerem alguma referência à situação brasileira ou à leitura do campo literário por Nestor Vítor.

Em uma das cartas, há uma referência explícita às supostas relações extraliterárias que atuavam para a "glorificação" dos intelectuais. Trata-se da carta de 6 de fevereiro de 1904, publicada no Correio Paulistano em 29 de fevereiro do mesmo ano.

Nela, Vítor, com o intuito de descrever os rituais da posse na Academia Francesa a partir do ingresso do historiador Frederic Masson em 18 de junho de 1903, acaba também por apresentar e analisar o espaço físico de consagração dos imortais. Ele passa os dez primeiros parágrafos apenas descrevendo e analisando o recinto da Academia, chegando no décimo primeiro a comparar com a situação da Academia Brasileira.

Interessante como, ao ver o espaço físico, Vítor enxerga também os lugares de distinção que cada posição no recinto representa. Indica, por exemplo, que o privilégio parece se deslocar das tribunas onde ficam os quarenta imortais para a plateia, ocupada pelos "notórios da França".

Mas faz-se plateia, ainda assim, porque, quando soa a hora marcada, - uma da tarde em ponto, - e que os altos societários, precedidos do formalístico huissier, apresentam-se na ordem regulamentar, logo em seguida, fazendo cauda, vem uma multidão de amigos com eles, entre os quais muitas senhoras, e sentam-se promiscuamente nas tribunas, de modo que os hóspedes se poderiam confundir 
inteiramente com os quarenta, se a estes não distinguisse o uniforme, em que se destacam a duas léguas as famosas palmas. A diferença é que neste caso os lugares da plateia é que são os mais privilegiados. Quase que só os ocupam os notórios de França (OC, vol. III, p. 123).

Nesse espetáculo, ao mesmo tempo, de distinção e de mundanismo, é preciso "andar cedo para obter um convite da secretaria ou dos vendedores disfarçados", de modo que a seleção dos acadêmicos acaba sendo projetada sobre o próprio espaço físico das reuniões.

Bem pensado, não andou mal quem circunscreveu por esse modo os acadêmicos
dentro daquele pequeno hemiciclo. Talvez venha daí um pouco o prestígio de
queeles gozam aqui, mesmo ainda hoje: da dificuldade que há em se poder assistir
aos seus cerimoniais. Esse limite, que a falta de espaço impõe, traz logo uma ideia
de seleção mesmo entre a gente da galeria, torna os lugares mais procurados
(ibidem, p. 124).

Dessa descrição analítica sobre o espaço de distinção dos acadêmicos, Vítor passa à comparação com a Academia Brasileira, reforçando ironicamente a influência daquela sobre esta e também denunciando, assim, as "glorificações" de "compadrio" que parecem ser tão próprias ao nosso meio.

\begin{abstract}
A Academia Brasileira, que em tantos outros pontos tem imitado, e com justa razão, a sua avoenga cá destas Gáulias, não se deve esquecer de lhe seguir o exemplo também nisso, agora que o governo vai lhe dar um local onde enfim se instale como quem está em sua casa. Guardando as devidas proporções, poder-se-á deixar espaço para uns sessenta espectadores. Esse talvez seja um meio para levar lá pelo menos mais de seis, dada a índole lastimável do nosso povo, tão avesso, pelo menos na aparência, a essas glorificações, que entre nós sempre se acha serem produtos de compadrio (ibidem, p. 124).
\end{abstract}

Como se vê, Nestor Vítor não perdia a oportunidade de criticar o meio intelectual brasileiro e agora o fazia a partir da "capital da civilização", Paris. Escrevendo para dois importantes jornais, $O$ País ("a folha de maior tiragem e de maior circulação na América do Sul", como vinha descrito em seu cabeçalho) e o Correio Paulistano (órgão de prestígio do Partido Republicano, criado ainda em 1854, ligado à oligarquia da província de São Paulo), Vítor podia difundir certos valores da sociedade francesa, ampliando assim a perspectiva de consagração cultural, mais restrito em nosso país.

A visita e a permanência em Paris aparecia, em seu discurso, muitas vezes, como sinal distintivo que nada tinha de natural, embora ele quisesse passar essa imagem, como a que ele expressa em carta de 14 de agosto de 1902, publicada em O País, em 04 de setembro do mesmo ano. 
É preciso vir a Paris - a obra suprema do gênio francês - para compreender como este é essencialmente claro, simples, humano. A arquitetura da cidade; os grandes museus em que os séculos têm vindo acumular os tesouros da arte de que a raça tem sido capaz; a gente que passa, tanto a que vem de carro, em grande tenue, como a outra mais modesta, passageira de tramway, ou mesmo simples pedestre; o tom e a maneira por que se fala; os modos de ver; a simplicidade e a franqueza com que se os expressa: tudo converge para nos dar uma impressão harmônica, de comodidade, de naturalidade, quase sempre sob a forma mais bem achada possível (OC, vol. III, p. 87).

Participando, como afirmei, dos valores dominantes da belle époque, Vítor busca um tanto exageradamente e de forma provinciana, nesse extrato, ratificar a crença no valor da vida parisiense, de modo que as relações que contrai, os lugares por onde circula, as palavras que lê e profere possam ganhar uma distinção simbólica ${ }^{49}$.

A suposição é de que, com esse conhecimento, ele volte a participar da luta no campo literário brasileiro investido de novos poderes. Não é à toa que em outra carta do mesmo ano, de 30 de outubro, publicada em 24 de novembro também em $O$ País, ele acabe por igualar o significado de sua produção (o livro de crítica A Hora, de 1900) com a novidade que representou o Canaã de Graça Aranha, de 1902, e possa fazer um balanço categórico da situação dos escritores e suas "escolas".

\begin{abstract}
Mas a verdade é que tanto lá na nossa terra como aqui na Europa, simbolistas e decadentes vão tendendo hoje, se não a desaparecer pelo menos a modificar sua feição primitiva. Dá-se o mesmo com os naturalistas. Os parnasianos, esses, pode-se dizer que já não existem. Naturalistas, simbolistas, decadentes, tendem a fundir-se no 'humanitarismo', menos preconceituoso, capaz de uma fórmula mais vasta quequalquer uma dessas tendências em si. Canaã, o belo livro de Graça Aranha, ficará marcando no romance o início dessa nova fase entre nós e não se me leve a mal lembrar que talvez o livro de crítica, A Hora, revele caracteristicamente tendências idênticas (OC, vol. III, p. 98).
\end{abstract}

A crença no caráter cosmopolita da arte fazia-o prever mudanças no campo literário brasileiro com base em sua observação da situação francesa, as quais poderiam beneficiá-lo.

49 Tenho usado aqui a noção de "distinção", de "sinais distintivos" pensando na análise proposta por Bourdieu. Obviamente, o grau de autonomia do campo cultural determina a eficácia de suas regras internas e a própria legitimação dos seus produtores. Sem forçar os conceitos e análises de Bourdieu, penso apenas como certos traços observados pelo sociólogo podem ser aplicados às crenças e aos valores desse período em que Vítor viveu e produziu seus textos. Por exemplo, aqui penso nas lutas simbólicas que Bourdieu descreve em A Distinção, particularmente quando ele fala da dinâmica próprio a um campo: “(...) A dinâmica do campo no qual os bens culturais se produzem, se reproduzem e circulam, proporcionando ganhos de distinção, encontra seu princípio nas estratégias em que se engendram sua raridade e a crença em seu valor, além de contribuírem para a realização desses efeitos objetivos pela própria concorrência que os opõe entre si (...)" (BOURDIEU, 2017, p. 233-4, grifo meu). Vítor acaba por reforçar o olhar "admirado" sobre Paris, reafirmando assim as crenças que a belle époque carioca forjava. 
No entanto, não é possível generalizar essa atitude, já que ele próprio também encara os sinais de distinção da cultura parisiense como próprios de um "interesse mundano", portanto, passageiros, como quando relata a posse de Edmond Rostand na Academia Francesa em 4 de junho de 1903 ou quando trata da execução da peça Rei Lear no teatro Antoine, expressa em carta de 8 de dezembro de 1904, publicada no Correio Paulistano em 31 de dezembro.

\begin{abstract}
(...) ilude-se completamente quem pensa que o público parisiense vive numa grande intensidade intelectual, e que ele, por conseguinte, requer a todo instante estar em comunicação pelo espírito com os produtores de primeira ordem de que a humanidade dispõe, que são os homens de gênio. Não, isso tem épocas, mas de espaço a espaço, às vezes bem distantes uns dos outros. Aqui, ao que se é invariavelmente fiel é ao chic, ao encantador (OC, vol. III, p. 135).
\end{abstract}

Reforçando ou destruindo as imagens que a belle époque carioca consolidava da França, de Paris, Vítor legitima ${ }^{50}$ as relações culturais mais amplas que também forneciam a consagração ao homem de letras do período. Participa, assim, de relações extraliterárias que lhe garantiriam no futuro um papel como leitor de "primeira plana", como asseguraria Sílvio Romero em janeiro de 1914 no Jornal do Comércio, sobretudo pelos estudos de Vítor em relação aos escritores estrangeiros (GONÇALVES, 1996, p. 103).

De volta ao Brasil, há, em 1906, como descrevi, um conjunto de textos significativos da sua produção crítica, em que ele, após a experiência europeia, volta-se para a produção nacional de forma panorâmica, escrevendo majoritariamente sobre livros recentemente lançados, a partir dos quais aborda Machado de Assis, Coelho Neto, Alberto de Oliveira, Mário Pederneiras, Júlia Lopes de Almeida, Fábio Luz, Sílvio Romero, João do Rio e outros. Em 1906, são ao todo doze artigos sobre livros e autores que ainda produziam e quatro artigos que "possuem um caráter de revisitação e recordação" (SILVEIRA, 2010, p. 99).

Apesar da produção intensa no ano de 1906, há poucas marcas da "política literária" nos textos. Talvez porque, tendo voltado há pouco de Paris, voltado mais "civilizado" conforme as palavras de João do Rio, houvesse diminuído a impressão das lutas vivenciadas entre 1896 a 1902, diminuído assim a percepção das próprias relações extraliterárias que

50 Como na nota anterior, aproprio-me da análise que Bourdieu faz quando ele trata da diferença entre o senso de "distinção" burguês e o senso pequeno burguês. De modo que, seja "exagerando" a distinção que é viver e conhecer a cultura francesa, própria do pequeno burguês, seja expondo os sinais de "distinção forçada" dos outros, por meio de um discurso crítico da mundanidade, Nestor Vítor acaba alimentando práticas de "gostos" próprias do período em que viveu. Conferir a seção “As lutas simbólicas”, in: BOURDIEU, 2017, p. 233-9. 
dominavam a vida literária na República Velha. O elogio que faz a Eugène Carriere, em um dos artigos de "revisitação" desse ano, parece mesmo dissociar a arte da vida social:

Não conheço uma figura na obra de Carrière que revele o que se chama uma ideia política, uma das que hoje chamamos preocupações sociais. A humanidade toda que ele fez apóia-se no sentimento eterno e não a conturbam as assoladoras paixões (OC, vol. I, p. 353).

Uma representação bastante ideológica do pintor que parece agradar ao nosso crítico nesse momento. Do mesmo modo, Vítor estabelece uma imagem de poeta "elevado" ao falar de Rubén Dario em artigo homônimo: “(...) o que ele é principalmente é um despreocupado de tudo o que não seja a pura arte e que não constitua o seu gozo pessoal. Ama Verlaine como a um deus Termo amava o agricultor pagão" (ibidem, p. 356).

Os anos de "civilização" na Europa amainaram o espírito combatente de Vítor, do mesmo modo que desfizeram a sua crença no futuro do simbolismo, aplacando assim o seu lado mais apaixonado.

Com efeito, ao tratar de um parnasiano como Alberto de Oliveira ou de um naturalista como Coelho Neto, ambas figuras consagradíssimas no período, parece voltado sobretudo para as questões estritamente literárias. Sem dúvida, ressalta-se a argúcia com que Vítor vai caracterizando a obra daquele, mostrando suas fases e transformações, e as consequências da produção em série da obra deste. Chega mesmo a escrever frases que demonstram acurada percepção do processo narrativo que se tornava cada vez mais vertiginoso com a aceleração do ritmo de vida pela tecnologia ${ }^{51}$.

Do ano de 1906, com exceção do artigo já referido sobre Machado de Assis, "Relíquias da Casa Velha por Machado de Assis", não há marcas evidentes da "política literária”. Há com mais evidência as escolhas pessoais de Nestor Vítor ao traçar comentários sobre os livros recentes. Assim, ao falar sobre o livro de Romero, Outros Estudos de Literatura Contemporânea, deixa claro, por exemplo, a sua inclinação à obra deste crítico, menos talvez pelas qualidades inatas de sua crítica e mais pela personalidade do autor, pelo comportamento de Sílvio no ambiente cultural brasileiro.

Nenhuma outra, de vulto, em nossas letras, caracteriza-se pelo vigor no combate, que ela revela, e pela franqueza das atitudes que implica.

51 "Coelho Neto é um grande virtuose da prosa. (...) Seu cérebro é como um excelente kodack: por onde ele passa os olhos, vai automaticamente tomando clichês que lhes ficam para sempre, nítidos e fixos, como platinotipias, na memória" (OC, vol. I, p. 374). 
Haverá erros, desvios inconscientes, mas não há refolhos nem contemplações, no que respeita a coisas essenciais, ali. Se existe um homem que tenha dito tudo quanto sente de mal, que haja denunciado quanto lhe pareça ser erro ou simples exagero, em relação aos homens, às coisas e às ideias, no seu país, esse é por certo o Sr. Sílvio Romero.

Mas o motivo pelo qual, apesar disso, o ilustre escritor goza de legítima simpatia entre nós, está em que, no fundo, ele é um dos espíritos mais confortativos que a época oferece, porque é um dos poucos que desabafam o que sentem de opressivo para continuarem a gozar da alegria de viver, a serem confiante, a serem crentes (OC, vol. I, p. 388-9).

O que reforça a identificação entre Vítor e Romero é o espírito de combate, sobretudo o combate a figurões do campo literário, como Machado e Veríssimo. O elogio ao crítico "menos literário" do período, embora atue, nesse caso, contra a autonomização do literário encarnada por essas duas figuras, revela a própria "política" de Vítor em relação ao meio.

De igual maneira, tendo voltado de Paris em meados de 1905, busca estabelecer contato com a geração que despontava no período, mesmo que não houvesse, de fato, identidade de escolhas estéticas entre essa geração e a dos simbolistas do final do século. É o que revela o artigo sobre o livro de Fábio Luz, “Os Emancipados por Fábio Luz”, citado ainda no primeiro capítulo.

Além da visão desoladora do ambiente cultural mais amplo, no qual os literatos viamse constrangidos pela nova dinâmica da belle époque com seus gostos mundanos e superficiais e no qual era inútil disputas por "escolas e tendências", há também a busca por alianças no meio, mesmo com representantes da mesma belle époque, como o escritor Paulo Barreto (João do Rio), o representante do dernier cri, ou Elísio de Carvalho, então "nitzscheaniano anarquista" $" 52$.

Ainda mais, não se trata de uma trindade isolada [Pedro do Couto, Curvelo de
Mendonça e Fábio Luz]. Eles foram os elementos primórdios de toda uma
agrupação que vim encontrar na minha volta, a que se prendem mais ou menos: um
nitzscheaniano e, não obstante, ao mesmo tempo, socialista, que é Elísio de
Carvalho; um espiritualista, cristão e algo espírita, que é Rocha Pombo; um
simbolista nefelibata de há pouco tempo, que é Gustavo Santiago (...); um filólogo e
gramático liberal, que é Maximiano Maciel; outro também gramático, pedagogista e
polemista, que é Hemetério dos Santos; esses e talvez alguns mais, cujos nomes me
escapem de momento, todos homens já bastante conhecidos, além de diferentes
rapazes, alguns sobre os quais se depositam muitas esperanças, mas cujos nomes
ainda não entraram na grande circulação.
Dá-se ainda que em torno do grupo mais propriamente dito andam vários indivíduos
que, se não aderem, simpatizam com os adesos, totalmente ou em parte, ou então

52 Figura relevante do período, estudada por Prado em 1922 - Itinerário de uma falsa vanguarda, que, nesse momento, dirigia o grupo da revista A Meridional, a qual vinha "para consagrar Elísio de Carvalho como um sucessor mais atuante do grande Cruz e Sousa" (PRADO, 1983, p. 12). Autorrepresentação "vanguardista" que deve ter chamado a atenção de Nestor Vítor nesse período. 
que antes gozam da simpatia deles, como acontece, por exemplo, a João Ribeiro, um escritor de reputação totalmente feita, acadêmico, bastante parnasiano outrora e atualmente fervoroso classista; a Múcio Teixeira, irredutível romântico, apesar de todas as múltiplas evoluções exteriores de seu espírito; a Paulo Barreto, o 'príncipe', realista por natureza e dernier cri até a médula, valoroso moço por cuja candidatura à Academia alguns dos grupos atualmente trabalham; a esses e a outros que dão menos na vista. $\mathrm{O}$ autor desse artigo, por exemplo, não é de modo algum antipático a quem quer que seja dos que compõem a agrupação referida (OC, vol. I, p. 401-2, grifos meus).

Nomes os mais diversos que representavam uma aposta de futuro e que eram lidos por Vítor como uma passagem para as tendências da "hora", para seu reingresso no campo literário depois de anos de ausência ${ }^{53}$.

Não é de espantar que, além desse elogio a Paulo Barreto, nesse mesmo ano, Vítor escreva também um artigo intitulado "As religiões do Rio por João do Rio", comentando o novo gênero, a reportagem, e o fato de ser uma "obra-prima" do gênero. Embora condene de uma forma mais ou menos geral os que abraçam a carreira jornalística, rotulando-os de “desclassificados, e entre estes, em boa parte, os inclassificáveis, por inaptidão ou por fraqueza" (OC, vol. I, p. 383), abre uma exceção para Paulo Barreto que "procura ser um escritor elegante e de bom gosto, portanto essencialmente um hodierno, porque não se pode ter aquelas qualidades sem ser isto, elegância e bom gosto querendo dizer inteligente, fina conformação com o momento" (ibidem, p. 384).

Nestor Vítor que buscava construir a imagem de um homem avesso à mundanidade, faz aqui uma concessão a ela, na filiação que estabelece com autores novos do período e com o elogio aos textos dos mesmos. Como apresenta certa consciência do papel do jornalismo, "feito de exibição", busca conciliar essa postura com uma amenização do caráter mundano dessas manifestações.

Quem olhar bem atentamente para estas páginas das Religiões no Rio observará: no fundo daquele espírito, que a todo transe se quer fazer absolutamente mundano, despreocupado, amoral, e até mesmo um tanto ou quanto irreverente, há os disjecti membra de um homem de princípios e até, de modo mais vago ainda, os de um indivíduo capaz de ter uma crença. João do Rio não pôde conter de todo a sua repulsa quando nos fala das práticas nauseantes e grotescas da feitiçaria africana e da exploração sem vergonha, muitas vezes criminosa, dos espíritos falsificados. (ibidem, p. 385)

53 Ao falar de Coelho Neto, em artigo de 1913, Vítor resume bem a necessidade que os escritores têm de estar in loco, de participarem do meio carioca para manter seu prestígio no meio intelectual: "Fez ele muito bem em voltar do estrangeiro, quanto antes. Não há no Brasil um homem cujo prestígio resista intacto a muitos anos de ausência. Esta ainda não é uma terra de delícias e instintivamente todos nós fazemos questão de que aqui estejam participando conosco das nossas vicissitudes íntimas quantos queiram ser por nós vivamente amados" (OC, vol. I, p. 449). 
Se a função, o trabalho e o gênero afiguram-se "mundanos", salva-se a figura. Pelo elogio da moral do homem, conserva-se o elogio da obra analisada. Nestor Vítor, no retorno de Paris, busca conciliar tanto as suas antigas convicções como alinhá-las aos novos tempos, buscando se reposicionar no campo depois de três anos fora. Não é estranho, portanto, que, ao lado de textos que fazem elogio da "arte pura", existam textos como esse que concedem status a gêneros "mundanos", como a reportagem. É um período de transição como sugiro no título dessa subseção; de transição e de intervalo.

A produção crítica de Nestor Vítor, como afirmei no primeiro capítulo, sofre uma espécie de hiato entre os anos de 1907 a 1911. Além das atividades do magistério e da vida política que também preenchiam o seu tempo, conforme já indiquei, “os anos de 1907, 1908 e 1909 foram dedicados à confecção de seu livro Paris, somente publicado em 1911" (GONÇALVES, 1996, p. 28), Assim, apenas em 1911 encontramos novos apontamentos sobre as relações extraliterárias que, na visão de Vítor, enformavam o meio intelectual carioca e brasileiro.

\subsubsection{Alguns artigos da década de 1910}

Os anos de 1910 representam a consolidação de Nestor Vítor entre a intelectualidade carioca.

Em 1911, publica Paris, livro de narrativa de viagem, que seria reeditado já em 1913 e que, em jornais como $O$ País, recebeu boa acolhida ${ }^{54}$. Nesse mesmo ano, publica $A$ terra do futuro que trata de o seu Estado natal, o Paraná. Em 1915, escreve a introdução ao livro de poemas de Dias da Rocha Filho, Poesias, e apresenta o seu livro Elogio da criança, no Centro Paranaense. Transforma sua conferência "Três Romancistas do Norte" em livro em janeiro de 1916. Em 1917, publica o longo estudo sobre a obra de Farias Brito em livro de 101 páginas, dedicado a Rui Barbosa. Em 1919, publica A Crítica de Ontem e, em 1920, o livro Folhas que ficam, escrito quase todo antes de 1914. Isso para falar apenas dos livros que apareciam com seu nome estampado na capa. Há ainda estudos que não saíram em livro no período, mas

54 Pude encontrar ao menos 6 notas ou artigos sobre o livro Paris no jornal O País entre dezembro de 1911 e julho de 1913, quando então se anunciava a publicação do livro e se comemorava a sua $2^{\mathrm{a}}$ edição, respectivamente. As edições de $O$ País, como de outros periódicos, podem ser consultadas na página eletrônica da Hemeroteca da Biblioteca Nacional. Disponível em http://memoria.bn.br/hdb/uf.aspx. 
somente nos periódicos, como "Matias Aires" publicado na Revista Americana entre junho a agosto de 1915.

Ainda que nem todos os livros publicados tratem de crítica "literária", como acontece sobretudo com Paris, A terra do Futuro, Elogio da criança e Folhas que ficam, o que Vítor alcança nesse período é o reconhecimento de seu estatuto como homem de letras, como um "festejado homem de letras" 55 .

Dos textos desse período, já fiz alguns comentários, a exemplo dos artigos sobre os livros de Ronald de Carvalho (1919) ou mesmo o retrato que Vítor descreve do campo cultural em "Três romancistas do Norte" (1915). Prosseguindo, analisarei dois artigos anteriores a 1914, um sobre o consagrado escritor Coelho Neto e outro sobre o estreante poeta Hermes Fontes. Ambos com destaque para a política de inserção dos escritores no campo cultural.

O primeiro é o artigo "A festa a Coelho Neto", de dezembro de 1913, reunido em $A$ Crítica de Ontem. No artigo, Vítor desenvolve a mesma avaliação que já esboçara em relação a Olavo Bilac. Chega mesmo a comparar os dois como representantes daquele momento histórico, daquela "hora" "com as qualidades e os defeitos que esta possa ter" (OC, vol. I, p. 446).

Diferente do artigo de 1906, em que verifica o ritmo de trabalho em série de Coelho Neto, apontando apenas brevemente as consequências negativas disso para a execução de suas narrativas, nesse artigo de 1913, de notícia às celebrações em torno do escritor, Vítor tece duras críticas ao meio intelectual que consagra um homem mais voltado à busca de sucesso do que ao trabalho constante e "respeitável". Por esse caminho, Vítor alimenta as disputas do meio, comparando as figuras de Coelho Neto e Olavo Bilac a de Sílvio Romero, ainda vivo, mas que não recebe os festejos que aqueles recebiam.

Grandes e valorosos trabalhadores já não faltam nas letras brasileiras. Que outro
vulto temos nós mais respeitável do que Sílvio Romero, por exemplo, de tal ponto
de vista? Mas quem é que vai agora lembrar-se de promover uma festa para
proclamá-lo o maior crítico nacional, ou de organizar e oferecer-lhe banquete
quando ele chegue até de uma viagem que possa fazer à China?
Sílvio Romero é essencialmente um escritor pugnaz, por isso mesmo nesse ponto
avesso à índole nacional e principalmente em desacordo com o instante que
atravessamos, que é o instante por excelência dos conúbios, dos esquecimentos, de
queixas calculadas, dos arranjos a todo custo no terreno das conveniências para os

55 Expressão comum que o jornal O País utilizava para se referir aos literatos, como Coelho Neto, Olavo Bilac, Emílio de Menezes e outros, e aplica ao nosso crítico, por exemplo, na edição de 5 de agosto de 1913 ao falar do aparecimento do livro A terra do futuro. Conferir site da Hemeroteca da Biblioteca Nacional, período de 1910 a 1919. Disponível em http://memoria.bn.br/hdb/uf.aspx 
triunfos práticos. Vive cheio de desafetos, de antipáticos, que ele próprio criou, às vezes mais pelo ardor do seu temperamento do que pela razão que lhe assista, outras vezes inteiramente coberto de razão. Isso faz com que até muitos a quem ele não tenha agravado nem de longe o aborreçam gratuitamente ainda assim. A ombridade, a coragem, só porque o são, conluiam contra nós todas as almas de lacaio. Não é que ele deixe de ter também seus fiéis, seus amigos, seus admiradores. Mas estes não constituem a alegre e disposta companhia própria para promover os festivais mundanos que a um Bilac ou a um Coelho Neto é tão fácil e tão grato oferecer-se. É fácil e grato porque tudo concorre para isso, sendo eles já naturalmente favorecidos pelo meio, a que tão felizmente se ajustam. Festejá-los é cairmos no gosto do público prazenteiro por nossa vez (OC, vol. I, p. 447).

Nestor Vítor, que já estabelecera ótimas relações com Romero e que reconhece o trabalho de vulto do crítico, aponta mais uma vez as injustiças do meio, o caráter mundano dos grupos dominantes. Embora reconheça que Sílvio também tenha "seus fiéis, seus amigos", estes não estão ligados à mundanidade nem às altas rodas da elite da belle époque carioca.

Além desses comentários sobre o meio cultural, Vítor também desenvolve análises da obra do romancista, afirmando, por exemplo, que aquilo que salva parte de sua produção é sua "fértil capacidade de idealização objetivista, pela qual se tornou ele um pintor abundante da vida brasileira", embora essa qualidade seja alcançada "sem fundos intuitos filosóficos, sem grande novidade nos processos" (ibidem, p. 447). Aliás, afirma que Coelho Neto, ainda que prodigioso no volume da produção, repete processos de criação, tornando-se "monótono".

Mais do que isso, elaborando um quadro de comparação com José de Alencar, Vítor começa a esboçar com maior clareza um retorno à tradição romântica, à defesa de certa simplicidade na composição e, com isso, à defesa de um critério que poderíamos chamar de "populista”, que é a defesa da correspondência entre as formas e os conteúdos dos textos literários e o público leitor da época. É esse critério que se tornará bem claro nos anos 20 e que lhe servirá para afirmar anacronicamente que o naturalismo nunca correspondeu verdadeiramente ao espírito de "nosso povo". No artigo presente, quer passar uma ideia do público leitor:

Ele não tem o poder de penetração e influência que teve Alencar na alma de toda a gente mais ou menos capaz de ler no Brasil. Falta-lhe aquele ardente lirismo do grande romancista cearense e o poder de transfiguração que havia neste, pelo qual principalmente quase todos os tipos femininos que descrevia lhe saíam da pena tão mimosos, tão amoráveis, tão idealmente brasileiros, tão capazes de cativar a nossa geral estesia. A visão de Coelho Neto, com ser também lírica, é mais naturalista, não na acepção de brutalidade, mas na de fidelidade, de literalidade, quando não de vulgaridade antes. Além disso, ela se complica com a influência das leituras de hoje, com a reminiscência dos tipos criados por Balzac, por Flaubert, por Zola, pelo Eça. Coelho Neto é muito mais "intelectual" do que o autor de Iracema, mas por isso 
mesmo não pode ser assimilado pelo nosso povo como ele foi. Na forma é de uma técnica que o tornará verdadeiramente precioso (no mau sentido da palavra), difícil, estranho, à multidão de semi-analfabetos que aqui constitui grande parte da massa ledora de folhetins de jornais (ibidem, p. 448).

Diferente de outros artigos do passado em que buscava mostrar que a "hora" dos naturalistas e dos parnasianos já havia passado, agora ele começa a construir a ideia de que nunca houve verdadeiramente um tempo para esses artistas no país. Que o espírito "objetivista", "precioso", de uns e de outros, nunca correspondeu ao "espírito" nacional, à tradição nacionalista romântica, ao sentimento espiritualista do povo.

Desenvolverei nos próximos capítulos como se expressa a cristalização dessas ideias já esboçadas aqui. Agora interessa encerrar o comentário do artigo, apontando ainda as relações extraliterárias que, na visão de Vítor, favoreceram o escritor consagrado. Nesse sentido, a conclusão do nosso crítico é que somente a política literária que Coelho Neto conseguiu realizar é que o mantinha ainda "à tona".

O que vale principalmente a Coelho Neto, porém, pelo menos enquanto vive, não é
tanto a sua avultosa produção, como as condições em que ele se soube colocar para
propagá-la, para valorizá-la, para tirar dela todo o partido possível. O que o salva no
dia de hoje é mais a sua capacidade de aliança com os elementos capazes de o
conservarem sempre à tona, de completarem pela boa vontade, pela simpatia
humana, pelo faccionismo, que esses sentimentos tanto ajudam, o que falta de
legítimo entusiasmo na nossa atmosfera pelo irredutível valor de sua obra (ibidem,
p. 449).

Tomar o "partido possível", fazer "propaganda" de si é o que ironicamente Vítor entrevê do sucesso de Coelho Neto. A oposição às práticas dominantes no campo literário revela mais uma vez a existência das disputas e dos grupos diversos e o modo pelo qual, a partir dessas disputas, os autores podiam ser melhor lidos ou não.

Considerando ainda o meio e as escolhas dos literatos para uma boa inserção no campo, Vítor em artigo de 1913, "Hermes Fontes", esboça uma recomendação ao jovem poeta que então publicara Apoteoses enquanto descreve as suas filiações literárias.

Conforme o crítico, Hermes Fontes chamou a atenção de "quase todos nós que constituímos o centro literário e jornalístico do Rio" (OC, vol. I, p. 454), porque ele conseguiu relacionar-se bem com escritores das mais diferentes tendências, o que, segundo Vítor, era um fator para impedir que o jovem poeta aderisse a um grupo dominante e monopolizador em particular. 
A um perigo, é certo, parecia furtar-se o jovem escritor: ao de prevalecer-se da sua recente notoriedade para entrar em compromisso desde logo com as forças ocasionais monopolizadoras do meio, as quais em todos os tempos distribuem posições e garantem mais fácil renome àqueles que correm a formar decididamente com elas.

Não é que assumisse posições agressivas contra quem quer que fosse dentre os representantes das correntes que já veio encontrar definidas e mesmo já mais ou menos históricas. Acontecia que por sua orientação inicial se apresentava ele até como um árbitro entre o Parnasianismo, o Realismo e o Simbolismo, sem que no entanto sua obra viesse a significar um meio-termo jeitoso ou velhaco (ibidem, $p$. 455).

Vítor parece, com suas palavras, delinear os espaços disponíveis no campo literário, revelando que, assim como ele, os escritores mais conscientes sabiam como se mover para evitar choques mais contraproducentes com as "forças monopolizadoras do meio", sem necessariamente, com elas, "entrar em compromisso". O fato de que o poeta vinha recebendo bons elogios por todos os lados permitia que ele fizesse mais escolhas do que fosse "escolhido".

Para um crítico que combateu as agremiações oficiais, ver um novo escritor surgir com um sucesso repentino sem a ligação, digamos, "orgânica" com estas e sem relações econômicas que o beneficiassem de imediato era um fato a ser comemorado. Para a crítica do próprio campo, a origem social de Hermes Fontes era um elemento distintivo.

\footnotetext{
Juntando-se a estes traços mais uma anotação, fazendo-se ver que a par de tudo isso ele é um filho de si mesmo, produto dos seus próprios esforços, sem valimentos que parentescos ou compadrios expliquem, é fácil antecipar que ele não nasceu destinado às prontas e milagrosas vitórias no mundo das posições, e não custa calcular-se que sem dúvida a vida não lhe tem sido um brinco e que lhe há de amargar a boca mais a miúdo do que àqueles que já nasceram feitos, pelos privilégios do berço, ou que aceitam figurar no papel de truões, quando não seja de aventureiros de alto coturno (ibidem, p. 456).
}

A disposição original de Vítor para a crítica foi a de combater em nome dos valores secundarizados pelos círculos oficiais das letras. Esse era o sentido da posição de nosso crítico no final do século: entre a utilização de critérios estéticos e não-estéticos dinamizava a constituição da autonomia relativa do campo literário brasileiro. A exclusão de Cruz e Sousa e dos simbolistas do cânone forjou nele a crítica elogiosa aos que também exibiam marcas de exclusão. No caso de Hermes Fontes, ao lado das qualidades "estéticas" que ele e outros enxergaram, há esses dados do meio econômico e cultural que o elevavam ainda mais e que surgiam então como critérios para a valorização da obra, mostrando mais uma vez como a crítica de Vitor, como a de outros críticos, não era estritamente literária. Ou era, quando se 
assume que o "literário" enquanto categoria de apreensão, no período, é algo mais do que somente o manifesto nos livros.

Daí também que, na visão de Vítor, Hermes Fontes possa ser enquadrado a uma linha de poetas aparentemente distintos, como Castro Alves, Luís Murat e Cruz e Sousa. Isso porque, naquele início dos anos 10, o "literário" para Vítor começava a ser o que se fíliava à tradição romântica do país, passando pelo simbolismo e desembocando no "melhor" da produção do período, expressa aí em sua leitura da poesia de Apoteoses.

\subsubsection{A revisitação do passado nos anos 20}

O último período da crítica de Nestor Vítor é marcado por duas preocupações básicas: compreender a produção dos vanguardistas, divididos, pelo menos, em duas alas, como eu discorrerei no quarto capítulo, e revisitar autores e obras do passado. Para os propósitos deste capítulo e com objetivo de encerrar a discussão em torno da "política literária", tratarei de dois artigos desse período que se enquadram nessa segunda preocupação. Um artigo sobre a monografia de Andrade Muricy, "Emiliano Perneta", e um estudo mais longo, publicado em duas edições do jornal $O$ Globo, do qual Nestor Vítor fora o primeiro crítico literário oficial, intitulado "Graça Aranha", de $1930^{56}$.

Reunido no livro Cartas à Gente Nova, de 1924, o artigo "Emiliano Perneta" foi escrito em Curitiba em 12 de março de 1920. Vinha reforçar os laços de amizade e de gosto intelectual comum que se estabelecera há alguns anos entre Andrade Muricy e Nestor Vítor. A afinidade entre os dois homens de letras faria com que Muricy se tornasse o "herdeiro" oficial do simbolismo e da obra de Nestor Vítor ${ }^{57}$.

Usando a legitimidade conquistada ao longo das décadas anteriores, Nestor Vítor tece os maiores elogios à monografia Emiliano Perneta, indicando que o seu autor se consagrava como um dos que poderiam continuar "a obra dos fundadores da crítica e da história literária do Brasil” (OC, vol. II, p. 179).

Vítor tem a consciência de que Emiliano Perneta representa uma "hora" da produção literária que não é a hora atual. Fato que não o leva a desprezar a produção do poeta

56 Embora cronologicamente os textos de 1930 não possam ser enquadrados como dos anos 20, eles participam do clima cultural e da formação social de nosso crítico nessa década, encerrando, inclusive, a produção coligida de Vítor nos jornais. Em 1932, já afastado dos jornais e sem livro novo desde 1924, ele faleceria.

57 Como se sabe, Andrade Muricy foi o responsável pelo Panorama do Simbolismo Brasileiro, de dois volumes, publicado em 1973, e pela "Introdução" ao primeiro volume da Obra Crítica de Nestor Vitor. 
curitibano, - há, na verdade, como se sabe, uma afinidade histórica entre Perneta e Vítor -, mas a criticar novamente o meio cultural brasileiro que não conseguiu enquadrar os poetas simbolistas no período em que surgiram e se desenvolveram. A presença tão prolongada do parnasianismo impediu que se historicizasse o simbolismo como manifestação de um momento particular de nossas letras.

Emiliano Perneta é uma individualidade que já devia estar colocada no quadro da nossa literatura quase que de um modo histórico. Embora ainda vivo e ainda vivaz, (...) é representante de uma hora, nas letras sul-americanas, que já não se confunde com a hora atual.

Foram tais, porém, até aqui, o zabumba e o fogo de Bengala feitos à demorada e por fim tediosa passagem dos representantes do parnasianismo entre nós, que, não só o vulgo, mas até ouvidos finos, vistas argutas, não poucas, houve e ainda há, por enquanto, que mal se aperceberam e se apercebem do vulto inconfundível desse nosso poeta, cujas notas, a um tempo frenéticas e flébeis, como as soubestes caracterizar tão bem, dão às nossas letras um sabor sem o qual elas não teriam refletido certos tons peregrinos, como os que um Baudelaire, um Verlaine, um Mallarmé, um Francis James acharam para enriquecer a gama da música verbal no Planeta (OC, vol. II, p. 179-80).

A queixa contra a permanência do parnasianismo e a falta de leitura dos simbolistas não é descontextualizada, parte, no entendimento de Vítor, da situação cultural do país que sempre privilegiou os escritores concentrados na capital, o Rio de Janeiro. O pouco poder que emanava da maioria dos Estados refletia-se no pequeno ou quase nenhum domínio na esfera cultural. Assim, Vítor demonstrava que a aliança com o poder econômico e político do Rio de Janeiro, necessária para qualquer homem de letras do período, acabava tornando mais mesquinho o campo literário brasileiro.

Desde que esta [a luta] já quase não existe nos Estados, sentem os neles influentes
sob qualquer aspecto que para se perpetuarem nas posições basta-lhes viverem
aliados aos poderes centrais do país. Politicamente é o Governo Federal quem pode
intervir por modo a fazer cair por terra qualquer Governo de Estado. Literariamente
o Rio é que tem uma imprensa capaz de levar aos quatro cantos do Brasil o nome de
um autor qualquer. Se já se não veem nos Estados movimentos intelectuais
consideráveis como os que houve até há pouco em diferente deles, conforme neste
livrinho demonstras, o prático, para quem está fora do meio carioca, é tratar de obter
as boas graças dos literatos e dos jornalistas, que residem aí. Mas, porque assim
acontece política e literariamente, o centro, tendo o sentimento da sua força cada vez
maior, vai tratando cada vez mais desdenhosamente esses desafortunados
provincianos (ibidem, p. 180).

O que Vítor via era que a política geral e a "política literária" entrelaçadas conformavam um quadro que dificultava a "justiça" aos "literatos provincianos". Dificultava, inclusive, por meio de "mistificações" e de "falsas vitórias", a consagração mesma de bons 
escritores cariocas que tinha dificuldade de se manter no meio literário do Rio de Janeiro. A vida mundana expressa nas revistas e nos jornais impedia que a "justiça” em geral ocorresse.

O único Estado que conseguia fazer frente ao Rio de Janeiro era São Paulo. O destaque a "Paulicéia" servia então a Vítor para que ele destacasse o novo contexto político e econômico de início dos anos 20 , que reformulavam a política literária existente até então.

\begin{abstract}
Parece-me que andaste muito bem em te referires ao Sr. Vicente de Carvalho do modo por que o fizeste a propósito de Emiliano Perneta. Trataste desassombradamente de mostrar que o poeta paulista, notável embora como é, não vale mais, e sim tem sido apenas mais favorecido pela crítica nacional, do que o poeta paranaense. Julgo, todavia, que não expuseste todas as razões desse favor maior.

Achas que o nosso "Heine" teve "uma franca vitória" em razão do seu "lirismo claro, simples e formoso, às vezes até dramático", enquanto "Emiliano é mais dificil, transmitindo-nos comoções para a compreensão das quais o grande público não está preparado".

Assim é, em parte. Mas outro elemento que influiu poderosamente para as honras com que se tem distinguido no Rio o Sr. Vicente de Carvalho é o ele ser paulista e de influência considerável na Paulicéia. S. Paulo, como não ignoras, é o único Estado, atualmente, que o oficialismo literário do Rio mostra considerar, a tal ponto que a coisa já sobe, em certos casos, a verdadeira adulação (ibidem, p. 181).
\end{abstract}

A ressalva que Nestor Vítor fazia a Muricy era em relação aos motivos de sucesso de Vicente de Carvalho em relação a Emiliano Perneta. Mais do que a suposição abstrata de qualidades inerentes à poesia de Carvalho, Vítor quer destacar as relações sociais que favoreciam o poeta paulistano em relação ao curitibano. Nesse sentido, a visada sobre a linguagem da poesia de Vicente de Carvalho podia encobrir o poder propriamente dito que emanava de uma posição econômica e social historicamente importante no período: a ascensão de São Paulo e a dos novos ricos do momento, como o poeta comentado. Novamente, é o olhar "sociológico" de Vítor que revela a política literária interferindo no sucesso ou não dos escritores da Primeira República.

Aliás, como afirma Miceli (2004), há nas questões de prestígio, de valor, a luta pelo poder econômico propriamente dito $^{58}$ embora encobertas, mediatizadas pelos sistemas simbólicos, como a "linguagem literária".

Vítor, ainda nesse artigo, percebia como a relação entre São Paulo e Rio de Janeiro poderia favorecer economicamente os escritores, dado o poder consumidor da "Paulicéia".

58 “O que está em jogo no campo simbólico é, em última análise, o poder propriamente político, muito embora não existam puras relações de força a não ser mediatizadas por sistemas simbólicos que, ao mesmo tempo, tornam-nas visíveis e irreconhecíveis pois lhes conferem uma existência através de linguagens especiais encobrindo as condições objetivas e as bases materiais em que tal poder se funda" (MICELI, in: BOURDIEU, 2004, p. LV). 
Diga-se mais, e para honra de São Paulo, que essa mirífica entente pôde estabelecerse e vai-se mantendo firme até hoje porque além das vantagens platônicas, já são grandes as de caráter mais prático dela auferidas pelos solertes aliados do Rio. O meio paulista já consome grande parte das edições de obras impressas em qualquer parte do país, quando sua imprensa se combina par fazer-lhes estrondosos reclamos. Também são rendosas as conferências que de visita aí realizam os literatos vindos da capital do país, quando os apóia francamente a nata intelectual de São Paulo. Os próprios pistolões que se obtenham dos políticos da Paulicéia são muito eficazes aos que se valem das letras para se irem fazendo cabides de empregos no meio carioca, e sabemos todos que em S. Paulo as letras e a política geralmente caminham de mãos dadas, graças ao espírito sensato dos herdeiros dos bandeirantes (ibidem, p. 181-2).

Formulação bastante consciente de Vítor que encara como o campo literário é perpassado pelas demandas e pelos interesses dos campos econômico e político. A experiência com o desenvolvimento rápido e intenso de São Paulo permitia uma observação sobre o funcionamento das letras nacionais, tornando mais evidente o que se encobria no Rio de Janeiro, através de mecanismos simbólicos, como as instituições consagradas de cultura.

As letras e a "política" caminharem de mãos dadas apareciam no espírito crítico de Nestor Vítor, dos anos 20, como uma constatação pacífica, restando apenas o uso da ironia para demonstrá-la mais abertamente, como acontece no extrato acima.

Conforme já disse, nos anos 10 é que a figuração das disputas e das lutas pôde ocorrer de forma mais "realista". Vítor, nesse momento, nos anos de 1920, está estendendo a análise iniciada antes, tornando mais concretos os elementos de que se utilizava para descrever e se contrapor às posições cristalizadas no campo literário. Assim, o próximo texto sobre o qual falarei, "Graça Aranha", de 1930, também faz uma leitura do campo e dos processos de consagração que elevaram o escritor de Canaã até a posição que tinha conquistado no início dos anos 20 .

O artigo "Graça Aranha", reunido já na obra póstuma Os de hoje, funciona como uma revisitação do passado a partir do escritor de Canaã. É dividido em duas partes: "Antes da Guerra" e "Depois da Guerra". Assim, de início, Vítor busca filiar Graça Aranha ao simbolismo em um período que o movimento era ignorado pela crítica oficial.

Pelo tempo em que ele apareceu, ainda José Veríssimo, na Revista Brasileira, hostilizava aqueles que tinham vindo com o poeta do Missal, dos Bregueis ${ }^{59}$ e que traziam com este a mesma ânsia de renovação.

Foi uma luta surda, mas no íntimo apaixonadíssima, essa dos nossos simbolistas com os naturalistas e parnasianos, mas luta quase apenas de bastidores, pois mal podiam os novos, então, fazer-se ouvir na imprensa, quase toda açambarcada pelos

59 Há obviamente um erro tipográfico, trata-se de Broquéis. 
outros. Estes, mal deixavam transparecer aqui fora, por táctica, a paixão que contra os dissidentes importunos os dominava.

Não havia remédio senão opôr à compressão o vitriolo do sarcasmo, nas conversas dos cafés e nas referências positivas ou transparentes que se lhes endereçavam em jornais e revistas de pequena circulação (OC, vol. II, p. 267).

O retrato lançado sobre o passado é bastante complexo e revela, mais uma vez, como a visada "sociológica" de Vítor permite entrever as disputas no campo, a luta pela apropriação dos capitais simbólicos disponíveis, a omissão dessas lutas pelo silenciamento da crítica dominante e a ação "foquista" dos grupos marginais que tentavam driblar os espaços já demarcados.

Nesse revisitar do passado, Vítor também revela como a influência estrangeira conformava ainda o meio literário brasileiro. Os críticos oficiais, a exemplo de Veríssimo, chamados por ele de "velhos", teriam que progressivamente aceitar o simbolismo, porque a crítica na Europa assim o fazia também paulatinamente. Além disso, Graça Aranha, muito bem posicionado no campo, pois era "amigo de Veríssimo, de Machado de Assis, de Joaquim Nabuco, de Taunay, criadores ou sustentadores da Revista Brasileira, inesperadamente publicou Canaã" (ibidem, p. 268).

Na perspectiva de Vítor, Graça Aranha, além de bem posicionado, foi lido por sua "palavrosidade metafórica" como um continuador dos românticos, ainda que ele próprio, Vítor, houvesse lido, em 1902, Graça Aranha como um herdeiro do simbolismo. A crítica oficial, da Revista Brasileira, de Veríssimo, pôde encontrar em Canaã o laço de ligação entre o passado, entre a tradição, e o "novo" representado pelas conquistas simbolistas.

\footnotetext{
Além disso, a língua, em Graça Aranha, melodiosa, quente, harmônica era contudo sem ousadias, disciplinada, conseguintemente, ainda por esse lado sem quebrar com a tradição, de que os chamados novos riam a bom rir, com neologismos e barbaridades sintáticas de arrepiar.

Não foi, assim, apenas porque o livro tivesse qualidades irresistíveis; mas, também, porque eles podiam, sem quebra de lógica essencial em seus princípios estéticos, levar para seus arraiais este outro novo, estranho aos simbolistas de patente e amigo deles, que os velhos receberam com extraordinário alvoroço, em claque cerrada, Canaã (ibidem, p. 268-9).
}

Embora o próprio Nestor Vítor tenha elogiado Canaã quando de sua publicação, em 1902, agora, em 1930, enxergava as relações literárias mais amplas que permitiram o seu amplo sucesso no período. A consagração de Canaã também serviu às disputas entre parnasianos-naturalistas e seus adversários de campo. Entretanto, Vítor "enxerga" o campo porque ele próprio está interessado em consagrar, nesse momento, uma nova visão sobre a 
história literária, construindo uma tradição para o simbolismo. Ou seja, busca revelar o passado para encobri-lo com sua própria perspectiva.

O próprio Nietzsche, Ibsen, Tolstoi, Dostoievsky, Maeterlinck, Verhaeren, D'Annunzio, por último Romain Rolland, o recém-divulgado Whitman, Tagore foram, até vir a guerra, dos tipos mais representativos entre esses exaltados espíritos. Todos eles precursores (os mais velhos) ou então os produtos, mais ou menos diretos, da escola simbolista, pelo menos devido à onda de misticismo que se desprendeu com essa nova sensibilidade estética.

Graça Aranha levantou resolutamente sua antena para entrar em comunicação com o mundo intelectual já no período em que o abstruso nefelibatismo dos poetas dera essa plena floração (ibidem, p. 270).

A vantagem de Graça Aranha em relação a outros escritores com a mesma sensibilidade criada pela "hora" foi ter estabelecido política literária com os figurões do período.

Canaã já foi escrita em parte na Inglaterra. Suas íntimas relações com Veríssimo e os outros prestigiosos colaboradores da Revista Brasileira proporcionaram a Graça Aranha um posto de secretário de legação. Foram amigos úteis, que o punham propriamente no mundo, para comunicar-se com o qual na verdade ele nascera (ibidem, p. 270).

Por ter sido posto no "mundo" por figuras reconhecidas no meio intelectual brasileiro, Graça Aranha respondeu a eles reafirmando certos valores consagrados do cientificismo. Segundo Vítor, o germanismo de Aranha atualizava e reforçava a visão sobre as raças.

\begin{abstract}
Até aos seus próprios antigos mestres da Escola do Recife, Graça dava um sinal de que não os abandonara, ao menos com aquela irresistível admiração pela cultural germânica, tão inseparável deles, também, por princípios. Todos sabem: não há um tipo dólico-louro em Canaã que, ao menos de certo modo, não revele superioridade, enquanto se mostram inferiores e, muitas vezes, até odiosos quase todos os brasileiros em contato com eles (ibidem, p. 271).
\end{abstract}

Graça Aranha, no entanto, não recorreu apenas aos representantes do movimento de ideias dominante em nosso país. Ele buscou horizontes mais largos que o elevaram a um patamar pouco conhecido entre os intelectuais do Brasil. Fez-se um homem conhecido na França, utilizando-se das relações com Rio Branco e conseguindo fazer propaganda de si, ampliando assim a aura que o cercava no início dos anos 20 .

Certo, só depois de ministro e aproveitando primeiro a monção que as larguezas inteligentes de Rio Branco permitiam, e depois com a guerra, quando a França precisava agradar todos os seus amigos, foi que Graça Aranha realizou quanto possível, o sonho de ser homem de letras, entendendo-se com o mundo europeu 
(...) Mas, de qualquer modo, ganhou altas relações o nosso patrício, teve elogios de um Bergson, de um Ferrero, de um Mauclair, de um Régnier e tantos outros. Publicou em francês Canaã e trechos de Estética da Vida.

Pelo menos de si mesmo fez a propaganda que pôde e o Brasil passou a ter um representante 'parisiense', isto é, conhecido e prezado entre os intelectuais de lá, de Paris, como tantos outros, sul-americanos, o são. Já não é pouco, para uma terra, nas condições da nossa, cujos governos quase nunca proporcionam tais cousas aos homens que na verdade têm valor, sobretudo sendo homens de letras (ibidem, p. 273).

Mas, se Graça Aranha fez a política literária, Vítor demonstra que os simbolistas também o fizeram, ainda que em escala menor. Ele sustenta a ideia de que a crítica foi importante para consolidar os escritores da tendência nova. A importação das ideias estrangeiras, dos autores europeus serviu para catalisar a assimilação dos nossos próprios inovadores. Ao falar do processo da crítica, da ação dos "admiradores" dos primeiros simbolistas, nosso crítico acaba por revelar o seu próprio papel no interior do campo literário. Os investimentos que fez para solidificar o simbolismo entre nós, para que ele se tornasse uma estética reconhecida e valorizada pelos escritores que se seguiram.

\footnotetext{
Mas por isso mesmo, era necessário a critica aclarasse entre nós quanto possível o valor daqueles quase asfixiados no momento, para que, até certo ponto ao menos, o publico os pudesse ver.

Alguns episódios houve que corresponderam a tal solicitação, pelo menos na medida que a gente adversa não pôde impedir. Se o velho e grande Sílvio Romero, como depois outros, também vindos do naturalismo, acabaram por sancionar o movimento consagrando suas figuras primaciais, foi muito em consequência de quanto fizeram os amigos que à primeira hora tais poetas malsinados conquistaram e dos discípulos que esses amigos já tinham feito.

Além disso, porém, os críticos do simbolismo, aqui, divulgaram, estudando-lhes as obras, os nomes dos vultos que na Europa já tinham por tal modo ampliado o movimento que mal podiam os olhos comuns discernir nas teorias paradoxais de um Rimbaud, de um Verlaine, de um Mallarmé, os princípios impulsionadores de tudo aquilo. Divulgaram-nos e fizeram ver o nexo existente entre uns e outros, precursores ou epígonos (ibidem, p. 272).
}

Nestor Vítor constrói, assim, um discurso sobre o passado em que esboça as estratégias para que o simbolismo se tornasse aceitável em nossas letras. Se os epígonos do movimento nunca alcançaram o mesmo prestígio que os parnasianos e os naturalistas, isso se explica pela falta de autonomia do campo literário, pelo mercado restrito das nossas letras e pela pouca diferenciação entre parnasianos e simbolistas, cuja relativa reversibilidade parece ser um traço dominante de nossa literatura ${ }^{60}$. As próprias ações descritas por Vítor revelam as

60 “(...) Até hoje os simbolistas brasileiros dão a ideia de um conjunto geralmente fraco ou, se quiserem, com apenas dois poetas, Cruz e Sousa e Alphonsus de Guimaraens, que seriam pouco mais fortes do que os sonoros parnasianos e o seu tambor. Por isso mesmo Salete faz observações pertinentes sobre o que lhe parece um traço próprio da nossa literatura: a relativa reversibilidade entre parnasianos e simbolistas" (Antonio Candido, 
relações extraliterárias, a política literária, a que os adeptos do simbolismo tiveram que recorrer para ter "sancionado o movimento" pela crítica oficial.

Com efeito, nesse texto de 1930, Vítor acaba por sintetizar a existência da política literária em nossas letras. A consagração ou não consagração no período dependia da "ciência das relações" que pouco tinham de literárias. Sejam os simbolistas, sejam os naturalistas e os parnasianos, sejam os novos escritores do século XX, todos lançaram mão de propaganda, de relações pessoais, de intervenção nas instituições culturais da República Velha para buscarem uma posição no interior do campo literário. Uma visão sintética e nada etérea que mostrava bem a diferença do crítico de 1896 e o crítico no final da carreira, em 1930.

Para encerrar a seção e o capítulo, posso afirmar que mais considerações poderiam ser desenvolvidas em torno do estudo "Graça Aranha", porque os comentários e análises feitos até aqui percorreram apenas a primeira parte do texto, restando a segunda, "Depois da Guerra”, no entanto, embora esta também traga descrições da política literária, o que foi dito até aqui, creio, conseguiu demonstrar a visão de Vítor sobre o campo literário e o papel da expressão "política literária" para a apreensão do mesmo. A segunda parte do artigo será analisada quando tratar da recepção crítica de Nestor Vítor em torno do movimento modernista, já que, após a Guerra, começa-se a sentir a influências das vanguardas europeias e o impacto das mesmas sobre os velhos e os novos literatos.

"Prefácio", in: CARA, 1983, p. IX). 


\section{NESTOR VÍTOR E O SIMBOLISMO}

\subsection{A historiografia em torno de Nestor Vitor}

A historiografia literária reservou a Nestor Vítor ${ }^{61}$ o papel de crítico do $\operatorname{simbolismo~}^{62} \mathrm{e}$ de herdeiro protetor da obra de Cruz e Sousa ${ }^{63}$. Considerando a incorporação do simbolismo em nossa tradição literária e a consagração do poeta negro, seria salutar avaliar o que, de fato, significou a defesa do movimento e do poeta nos textos de nosso crítico.

Alfredo Bosi (2006) chegou a afirmar que a experiência simbolista foi uma experiência "insular", no sentido de que ela não teve enraizamento na experiência econômicosocial do país. Entretanto, ainda que seja verdadeira ${ }^{64}$, essa interpretação não significaria que tenha sido uma experiência derrotada historicamente. Creio que a produção crítica de Vítor atuou como "arma de combate" para ingressar no campo literário, dominado pelas concepções deterministas e naturalistas. A associação com certos valores e referências tidas elevadas, as europeias "civilizadas", serviu, inicialmente, para elevar a arte do poeta Cruz e Sousa e a sua

61 Para essa discussão, da historiografia literária em torno do crítico Nestor Vítor, remeto à tese de doutorado de Allan Valenza da Silveira (2010) que reservou todo um capítulo para debater extensamente as imagens construídas em torno da produção do crítico. Assim, não problematizarei a oposição, por exemplo, entre o escritor ser um "crítico simbolista" ou "crítico do simbolismo", porque tal oposição remeteria a uma discussão em torno do "método” de Vítor que não é o objetivo do presente texto e que também já é tratada por Silveira. Acho corretos, nesse sentido, os pontos de vista do autor quando, de modo geral, afirma o caráter fragmentado da compreensão da obra de Vítor pela historiografia literária brasileira. Conferir especialmente o capítulo “A obra de Nestor Vítor nos estudos literários brasileiros”, in: Diálogos críticos de Nestor Vítor (SILVEIRA, 2010, p. 175-226).

62 Elenco alguns autores que fizeram referências à produção de nosso crítico, relacionando-o ao movimento simbolista: Bosi (1969, 2006), Brito (1964), Candido (1978), Carollo (1981), Carpeaux (1967), Carvalho (1998), Lima (1966), Linhares (1987), Lins (2009), Martins (1983), Muricy (1973) e Silveira (1963).

63 Essa imagem também é discutida por Silveira (2010), que relativiza o fato de Vítor ter uma produção voltada a muitos escritores de diferentes momentos de nossa literatura, não estando preso somente à "sombra" de Cruz e Sousa, o que, em nossa leitura, também é correto, considerando, por exemplo, os seus dois últimos livros Cartas à gente nova e Os de hoje, centrados em autores do chamado "pré-modernismo" ou mesmo modernismo brasileiro.

64 Há uma tese de doutorado, defendida em 2017 na UFSC, que se contrapõe à ideia de isolamento ou "insulamento" dos simbolistas da geração de 1890 no Brasil. Seu autor, Luiz Alberto de Souza, opõe-se diretamente à afirmação de Alfredo Bosi com a ideia de que é justamente após a instauração da República e fim da Abolição que o contexto histórico permitiu o surgimento dessa importação cultural já antes anunciada na década de 1880 por Medeiros e Albuquerque e Wenceslau de Queirós. Conforme o autor: "Contrariamente ao que diz a tradição crítica inaugurada por Veríssimo (e atualizada por Bosi), a 'floração estética' do simbolismo brasileiro, a sua difusão como modelo artístico, está profundamente enraizada na realidade histórica brasileira daquele contexto específico. Como busquei demonstrar nas duas partes deste trabalho, o simbolismo se viabilizou, de fato, como um 'movimento estético e ideológico' porque supria a determinadas demandas surgidas no interior de certos grupos sociais durante os anos que se seguiram à Abolição e à República. Se constituiu, em suma, como um modo particular de ver, sentir e pensar a realidade vivida pertinente à experiência concreta de alguns segmentos específicos da sociedade brasileira a partir dos anos 1888 e 1889". Cf. Souza, Luiz Alberto de. Os desclassificados do destino: Cruz e Sousa e os primeiros simbolistas, 2017, p. 450 . 
própria arte ${ }^{65}$, de maneira que, como compreendo, considerando as restrições do mercado literário brasileiro, foi um jogo de aparente derrota, a dos simbolistas.

Primeiro, porque, pelo que afirma Pierre Bourdieu (1996) em As Regras da Arte, há um jogo, uma estratégia, em que "quem perde, ganha" brasileiro, a impossibilidade de encontrar uma recepção favorável da crítica consagrada e de concorrer com o parnasianismo oficial no pequeno mercado das letras impôs uma necessidade de que, do próprio círculo de nossos simbolistas, de que Nestor Vítor era um representante, nascesse a crítica que toda obra e escritor esperam e, ao fazê-lo, que esta se legitimasse como a "única possível"67 e, ao final de um reconhecimento tardio e frágil, supusesse que ela é, conquanto fosse uma crítica "menor", ainda assim "a melhor" que o movimento poderia ter conhecido em seu curto tempo de vida ${ }^{68}$.

Segundo, porque o discurso em torno do simbolismo e de sua postura estética, e também, em parte, ética, se pensarmos na crítica recorrente ao mundanismo burguês e à postura do literato, atua ligando, ainda que como uma linha frágil, as experiências do final do século XIX às experiências do modernismo da década de 1920, quando o simbolismo, ao menos no discurso de Nestor Vítor, aparece como o elo mais natural para a vertente espiritualista dos escritores modernos, demonstrando que a aparente derrota de início converteu-se em integração e consagração a médio prazo no sistema literário.

Assim, seja a longo prazo, incorporado pela historiografia, seja a médio prazo, consagrado entre os homens de letras da época, o movimento simbolista alcançou um espaço próprio e, diria, relevante no meio cultural brasileiro. Lugar para o qual a crítica de Nestor Vítor contribuiu, transpondo certos obstáculos "oficiais", aqueles em torno dos quais tratei ao

65 É bom lembrar que Nestor Vítor também publicou, no "calor da hora" simbolista, livros de literatura como Signos (contos), de 1897, e Transfigurações (poesia), de 1902, que não estão sendo estudados aqui mas que revelam o engajamento do escritor em torno da literatura simbolista.

66 "(...) o jogo da arte é, do ponto de vista dos negócios, um jogo de 'quem perde ganha"' (BOURDIEU, 1996, p. 37).

67 Antonio Candido afirma isso ao constatar que os críticos secundários é que souberam ler o simbolismo: "Verifica-se a propósito um fato curioso, que se deu também na França, nosso modelo absoluto naquele tempo: os críticos mais considerados e de obra mais sólida geralmente não compreenderam nem apoiaram o simbolismo, que recebeu tratamento melhor de críticos secundários; por isso, hoje muitos tendem a considerar estes últimos com maior respeito. Na França, são homens como Rémy de Gourmont, Teodor de Wyzewa, Camille Mauclair, contrapostos a pontífices do tipo Gustave Lanson, Émile Faguet, Jules Lemaître, No Brasil, seria o caso de Nestor Vítor em face dos consideráveis Sílvio Romero e José Veríssimo" (CANDIDO, "Prefácio", in: CARA, Salete de Almeida. A recepção crítica, p. IX)

68 "Menor" e "melhor" são termos a partir dos quais se adjetivou a importância da crítica de Nestor Vítor. Ver Wilson Martins (A crítica literária no Brasil, vol. I, 1983, p. 329-334) e Alfredo Bosi (História concisa da literatura brasileira, 2006, p. 314-316). 
falar da política literária dominante, e estabelecendo pontes com a intelectualidade de seu tempo.

Com alguma consciência, o próprio Nestor Vítor atuou para se consolidar nas letras nacionais, seja porque se ligou, nos anos de 1920, a nomes que o evocariam ao longo das próximas décadas, como Tasso da Silveira ou Andrade Muricy, seja porque ele próprio se utilizou, também nos anos 20 , de pequenas rememorações do passado, manifestas em seus estudos e em seus artigos, quando reconstruía a "evolução" da literatura brasileira, entrelaçando-a à sua própria história pessoal durante a Primeira República ${ }^{69}$.

É o que se vê, por exemplo, no texto "Como nasceu o simbolismo no Brasil", de março de 1928, publicado em $O$ Globo, e que se inicia com: “Quando eu vim para o Rio, em 1888, o parnasianismo, no verso, e o naturalismo, na prosa, dominavam aqui sem contraste (...)" (OC, vol. III, p. 76). É um texto de rememoração, em que, mais claramente, Nestor Vítor coloca-se no plano da história e, como um crítico secundário, escreve sua biografia em relação ao simbolismo.

Segundo Miceli (2001), há uma diferença entre o gênero memorialístico e o gênero biográfico para a apreensão do papel e do lugar do intelectual em determinado momento histórico. Em geral, o intelectual consagrado, dominante no campo cultural, pode ter a sua vida contada por meio de biografias que obscurecem os fios das disputas para a sua consagração, enquanto o intelectual "menor", secundário, recorre a escritos memorialísticos para fazer a si mesmo a consagração que faltou em seu meio (MICELI, 2001, p. 20-1).

Nesse sentido, em muitos textos da década de $1920^{70}$ existem elementos de rememoração, o que parece sustentar a tese por mim já levantada que, embora tenha recebido maior atenção e reconhecimento após a Grande Guerra, Nestor Vítor não chegou a ocupar o lugar de crítico consagrado (embora assuma critérios da crítica oficial naturalista), o que confirma a sua posição na historiografia literária ${ }^{71}$.

Em alguns desses textos, ao falar sobre o simbolismo ou sobre autores simbolistas, relembra a sua própria trajetória, contribuindo assim para enaltecer o seu papel como crítico do simbolismo e favorecendo a imagem que dele a historiografia formaria.

69 Referindo-se também à última década de produção de Vítor, Silveira afirma: “(...) Muitas vezes, a história dos movimentos confunde-se com própria história do crítico, os caminhos trilhados por esta estética são semelhantes às escolhas feitas por ele" (SILVEIRA, 2010, p. 138).

70 Como os publicados na seção "Homens e temas do Paraná", reunidos no terceiro volume da Obra Crítica de Nestor Vitor.

71 Como afirmou Wilson Martins: "Nestor Vítor foi, sem dúvida, o quarto mosqueteiro da crítica brasileira oitocentista" (MARTINS, 1983, p. 329). 
Entretanto, são, de fato, poucos textos e pequenos trechos em que se utiliza dessa estratégia de se colocar na história como explicitamente portador de uma "herança" que deveria ser lembrada. Mais do que um escritor voltado para si, vislumbra-se em seus textos uma leitura do espaço da crítica e da criação literária do período, em que incidentalmente ele também se observa e se descreve.

Assim, no presente capítulo, objetivo apresentar e discutir as formulações em torno do simbolismo que aparecem nos textos críticos de Nestor Vítor, revelando as transformações de seu pensamento ao longo das décadas e contribuindo para uma compreensão mais global de sua obra.

\subsection{Levantamento sobre o simbolismo}

Se não é possível afirmar que Nestor Vítor foi apenas o crítico do simbolismo, como assevera Allan Silveira (2011), porque isso obnubila o papel que o crítico teve durante toda a República Velha no meio cultural carioca e a avaliação que elaborou, por exemplo, sobre os primeiros modernistas ou sobre toda a literatura conhecida como "pré-modernista", é possível garantir que o movimento simbolista foi peça fundamental do seu repertório intelectual e crítico e que perpassa o conjunto de sua obra.

Se considerarmos os textos de Vítor que tratam propriamente do simbolismo, verificaremos que estes são poucos e que aparecem, sobretudo, após a morte de todos os críticos oficiais do naturalismo (a partir de 1917). Mesmo nos textos dirigidos aos principais simbolistas que estuda, Cruz e Sousa e Emiliano Perneta, as referências explícitas ao termo "simbolismo" ou "simbolista" são escassas. Isso porque a tática, consciente ou não, de Nestor Vítor foi, em todos os momentos que tratou de autores e obras simbolistas, destacar caracteres éticos. Essa tática objetivava, por um lado, ressaltar as atitudes "elevadas" dos artistas, aproximando-se, por essa via, de certa noção romântica de "gênio" e, por outro, normatizar esses caracteres de modo a servir de contraponto à estética naturalista/parnasiana dominante.

Assim, poder-se-ia pensar seu investimento em torno do simbolismo em três momentos. O primeiro, ligado ao que denominei sua primeira fase, de 1896 a 1902, quando se utiliza de referenciais europeus para legitimar a leitura dos simbolistas brasileiros (Cruz e Sousa e Silveira Neto). Com tais referenciais, buscar destacar a diferença entre a literatura "impressionista", "simbolista", "mística" (termos variados de que se utiliza para buscar 
englobar autores distintos de uma tradição consagrada ou em vias de, como: Ibsen, Novalis, Shakespeare, Goethe, Maeterlinck, Cruz e Sousa) que teria um caráter universal, e a literatura naturalista e parnasiana, fruto de uma época excessivamente materialista, mas passageira. $\mathrm{O}$ segundo momento poderia ser caracterizado como de transição. Refere-se ao retorno de Paris e estende-se até meados da Primeira Guerra Mundial (entre 1906 a 1914), quando o crítico avalia que o simbolismo enfraqueceu, que sobrevivem os epígonos e ele não consegue ainda delinear claramente o caminho da nova literatura, apostando, como outros críticos do período, em autores como Graça Aranha, e voltando-se para os valores e os autores da literatura romântica nacional, que ele ignorara anteriormente.

Por fim, um terceiro e último momento de avaliação do movimento simbolista ocorre a partir de 1917, no seu estudo sobre o pensador Farias Brito. A brochura Farias Brito abre a série de textos em que Nestor Vítor realiza balanços e rememorações da literatura simbolista. Entre 1917 e 1930, há, sem dúvida, a fase em que ele mais explicitamente busca nomear e historicizar o simbolismo brasileiro. É nesse momento que mais claramente ele estabelece o vínculo entre simbolismo, romantismo, espiritualismo e nacionalismo. A lógica, muitas vezes forçada e tortuosa, com que ele consegue essa identificação e unidade tentarei revelar ao longo do capítulo.

Como o conjunto de textos que conformam os três momentos em torno do simbolismo (nos termos que coloquei acima) constituem parte significativa de sua obra, seria exaustivo tratar de cada um dos artigos, ensaios ou estudos relacionados ao tema. Também seria desnecessário um estudo exaustivo uma vez que o autor, por certa coerência interna na sua produção crítica, acaba por repetir pontos de vista e por retomar colocações de períodos anteriores, ainda que os modificando gradativamente, como veremos. Farei então análise e comentários de apenas alguns textos de cada um desses três momentos, elencando, quando necessário, aspectos originais e relevantes que existam em textos não analisados. Além disso, nesse capítulo, recorrerei a um texto importante, mas não publicado na Obra Crítica de Nestor Vitor, que é “Cruz e Sousa”, publicado em 1923, quando da primeira reunião das obras completas do poeta morto, que permite avaliar a mudança mais radical de perspectiva de Vítor frente ao poeta e ao movimento simbolista. 


\subsection{Diálogo com a "civilização"}

Antes de se mudar para Paris em 1902, Nestor Vítor já havia produzido alguns importantes textos críticos: a monografia Cruz e Sousa (1896/1899), o livro A Hora (1900), o estudo introdutório ao livro de Silveira Neto "O Elogio do Luar de Inverno" (1900), e também a "Introdução" ao livro A Sabedoria e o Destino (La Sagesse et la destinée, de Maurice Maeterlinck), por ele traduzido (1901), além de uma série de artigos, reunidos na primeira parte de A crítica de ontem que saíra em livro em 1919, mas que haviam sido publicados em jornais ou revistas entre 1898 e 1902, conforme o próprio Nestor Vítor afirma no prefácio da obra.

Havia, portanto, uma produção que o colocava entre os homens de letras do Rio de Janeiro. A partir das referências que ele contrapõe inicialmente ao preconceito de raça sofrido por Cruz e Sousa, ele busca dialogar com o que se considerava então a "civilização" moderna, a civilização europeia. Se não era possível encontrar uma recepção favorável ao simbolismo brasileiro, ele recorre a autores já consagrados ou em vias de consagração no cenário europeu para, a partir daí, estabelecer tacitamente vínculos entre a arte "civilizada" da Europa e os seus ecos na literatura simbolista nacional.

A tática de Vítor para se destacar nesse meio incluiu então apelar inicialmente para o sentido normativo do que significava a noção de "civilização" e apontar para os artistas que provinham de um ambiente imaginariamente mais civilizado. Imaginário compartilhado por toda a intelectualidade do século XIX e começo do XX, conforme já me referi, no primeiro capítulo, à “ilusão de se hipercivilizar" que tomava o Rio de Janeiro da belle époque. Segundo Terry Eagleton:

\footnotetext{
(...) a palavra 'civilização' é em parte descritiva e em parte normativa: ela pode tanto designar neutramente uma forma de vida ('civilização inca') como recomendar implicitamente uma forma de vida por sua humanidade, esclarecimento e refinamento. (...) E se civilização não é apenas um estágio de desenvolvimento em si, mas um estágio que está constantemente evoluindo dentro de si mesmo, então a palavra mais uma vez unifica fato e valor (EAGLETON, 2011, p. 20-1).
}

Na monografia Cruz e Sousa, Nestor Vítor utiliza três vezes a palavra "civilização". A primeira para criticar a visão unilateral de que ela apenas representaria progresso material: "Todo esse progresso, que é assim que tais cousas se chama, é apenas a metade de uma civilização" (OC, vol. I, p. 14). A segunda para afirmar que a arte de Cruz e Sousa é fruto da 
civilização moderna: “(...) para ser positivamente uma criação, um produto legítimo da Arte, precisa trazer em si os característicos como traz, da mais requintada, mas, em todo caso da contemporânea civilização" (ibidem, p. 23). Ou seja, para Vítor, o poeta Cruz e Sousa, a estética simbolista e a "hora" atual implicavam o conhecimento de "requintada civilização". Apenas os "Bárbaros", como ele denomina seus interlocutores de campo, não podiam alcançar a verdade dessa criação literária.

A importação de bens culturais funciona aí para tentar furar o cerco imposto pelos naturalistas e pelos parnasianos ao movimento dos novos escritores em nosso meio cultural restrito. Mais do que o elogio da "Religião da Arte", da "Arte" hermética, da "Arte pela Arte", da "Arte eterna", do caráter messiânico do artista e do "Verso-Abstração", todos termos e expressões utilizados em Cruz e Sousa, o primeiro texto crítico de Nestor Vítor trata do simbolismo como expressão da "civilização contemporânea", identificando as definições acima como parte da defesa da arte contra o campo literário brasileiro que, pouco autônomo, ainda queria ajustar-se mais a certas concepções da ciência (o racismo corrente que, de antemão, já excluíra a capacidade artística de Cruz e Sousa) e às demandas da nação brasileira, atrasada em relação à europeia, e, logo, atrasada em termos de produção artística.

Cita também, nesse sentido, em Cruz e Sousa, os nomes de Lord Byron e Dante Alighieri, como "belos rebelados das pátrias-madrastas" e igualmente deslocados de seu tempo-espaço cultural ao produzirem suas obras. Associa também as figuras femininas do poeta Cruz e Sousa à personagem "Serafita" de Honoré de Balzac (encarado em sua vertente “mística”) e aponta, por fim, que a rejeição que Cruz e Sousa sofria equivalia a de um leproso, ou pior, porque "ele é repelido pior do que se repele um leproso, ficando à porta da Civilização, numa trágica mendicidade de convivência e de afeto" (ibidem, p. 26, grifo meu), configurando aí a terceira aparição da palavra "civilização" em seu sentido normativo.

Em outras palavras, os "pouco civilizados" homens de letras do nosso país, atrasados em relação à arte europeia, sobretudo, francesa, atuavam com seus preconceitos para impedir os "civilizados" de fazer "ajustar os ponteiros do relógio" com a "Hora" atual. Ainda que a forma da monografia resvale para os aspectos éticos e até morais da postura da recepção crítica brasileira, denunciando o racismo das posturas dominantes, o seu conteúdo atua para defender a autonomia da arte diante das contingências nacionais.

Coerente com a noção do ajuste dos ponteiros e com a crítica aos preconceitos nacionais de um campo literário pouco autônomo, Nestor Vítor lança-se em três frentes 
críticas: traduzir e explicar o pensamento contemporâneo de Maurice Maeterlinck (representante do simbolismo belga e mais próximo da vertente místico-simbolista, conforme apontarei à frente), contribuir para a difusão da obra de Silveira Neto (a maior promessa, naquele momento, da literatura simbolista após a morte de Cruz e Sousa) e escrever sobre escritores europeus consagrados (como Novalis e H. Ibsen), contemporâneos ou não.

Em A Hora, lançado em 1901 pela H. Garnier, Nestor Vítor busca se antecipar à recepção de livros e autores estrangeiros que aqui ainda eram pouco conhecidos ${ }^{72}$. Neste livro, há um estudo sobre Les Déracinés, obra de 1897 de Maurice Barrès, que ele intitula "Os Desplantados de Maurice Barrès", escrito em 1898; um segundo estudo sobre Cyrano de Bergerac, obra também de 1897, que recebeu o título de "O Cyrano de Bergerac de Edmond Rostand", escrito em 1899, e, por fim, um longo ensaio sobre Henrik Ibsen, escrito em 1900, que ocupava a maior parte da edição de $A$ Hora da Garnier (mais de 120 páginas), intitulado "H. Ibsen".

Sobre esses textos, interessa-me destacar as críticas ideológicas que Vitor fez ao livro de Barrès e a interpretação em torno da concepção de artista que ele realizou a partir da obra de Ibsen.

Em “Os Desplantados de Maurice Barrès”, Nestor Vítor faz um arrazoado sobre o romance, descreve as personagens, as cenas, resume em longas páginas o livro para chegar a uma avaliação sobre a civilização francesa e sobre o caráter negativo que o nacionalismo poderia assumir. Isso porque a obra, segundo o crítico, atuava como um romance de tese, no qual a ideia principal seria demonstrar que os "desplantados", os rapazes provincianos que saiam do interior da França e seguiam para Paris, inevitavelmente não obteriam sucesso e enfraqueceriam a pátria.

É fútil, afinal, escrever-se um livro em Paris com o fim de dizer aos provincianos de França que é um grande perigo para eles pessoalmente, mas principalmente para a individualidade coletiva da Pátria, não já que eles emigrem do país, mas que se desarraiguem do solo literal em que estava assentado o berço onde eles primeiro vagiram. Nenhuma das grandes vozes que se fizeram ouvir em França e que a constituíram gloriosa como ela é, lhes falou desse perigo jamais.

$\mathrm{O}$ vigor de espírito de uma raça reconhece-se pela capacidade de resistência que nela exista a assimilar-se e dissolver-se em outra raça qualquer. Assim um povo; assim um indivíduo (OC, vol. I, p. 63).

72 Araripe Júnior já havia se referido a Ibsen ou a Maeterlinck antes de Nestor Vítor, por exemplo, em Movimento literário do ano de 1893 e em O crepúsculo dos povos, ambos publicados conjuntamente em 1895 e coligidos na Obra Crítica de Araripe Júnior, no volume III. No entanto, Nestor Vítor, ao que me consta, realizou as primeiras monografias sobre esses escritores, escrevendo assim os primeiros textos mais longos e analíticos sobres as respectivas obras. 
O nacionalismo tacanho que Vítor enxerga em Barrès talvez possa ser lido não tanto como uma crítica geral ao nacionalismo que, no próprio estudo, bem como em sua obra posterior, ele defenderá de alguma forma quanto pela estreiteza que esse nacionalismo impõe na assimilação de ideias e influências estrangeiras.

\begin{abstract}
Mostrarmo-nos receosos de influências intelectuais estranhas é já de qualquer modo nos revelarmos influenciados, pior do que isso, vencidos, porque o superior não é aquele que evita assimilar o que não tem; é justamente quem o assimila sem perder o seu cunho individual (ibidem, p. 64).
\end{abstract}

Se lembrarmos as palavras de José Veríssimo, ao avaliar a obra de Cruz e Sousa e a estética simbolista em 1896, talvez essas palavras de Vítor encontrem o seu pano de fundo, ligado ao campo literário brasileiro.

\begin{abstract}
Não há nessa reunião de poemas [Broquéis, de Cruz e Sousa], na maioria sonetos, nada, senão talvez a intenção gorada, que a faça classificar na poesia simbolista. São uma imitação falha de Baudelaire, modificado pelo poeta das Fêtes galantes.

(...)

A razão deste fenômeno um psicólogo facilmente a acharia na falta de sinceridade que assinala o nosso simbolismo. Entre nós, com efeito, esse movimento, se não é demais chamar assim às manifestações sem alcance e sem obras, não corresponde a um estado d'alma que por sua vez seja efeito de um estado social. É um mero produto de imitação ${ }^{73}$ (VERÍSSIMO, 1901, p. 91-2).
\end{abstract}

A ideia tão forte que pairou sobre Cruz e Sousa e sobre os primeiros simbolistas, entre os quais o próprio Nestor Vítor, de "imitação" e de não correspondência imediata com algum “estado social", parte, portanto, de uma concepção naturalista e determinista da arte literária enquanto produto direto da realidade social. Concepção que se supunha objetiva e se baseava, no Brasil do século XIX, na noção de nacionalismo literário que Vítor busca desfazer. A crítica ideológica que ele realiza a essa concepção estreita de arte e de nacionalismo pretende demonstrar que o cosmopolitismo e o universalismo conformam a "hora" atual. Nessa visão otimista, que seria, em parte, destruída com o alvorecer da Primeira Guerra, a grandeza da arte e dos escritores considerados geniais, para os quais o até o "Planeta" é uma "estreita pátria", estaria na assimilação do melhor da produção estrangeira, civilizada, e não apenas nos modismos de época, identificados por ele ao cientificismo determinista da crítica naturalista que dominava o país e que o impedia de abrir-se ao novo em função de uma imagem cristalizada de patriotismo:

73 Para facilitar a leitura imediata, fiz a atualização do texto de acordo com a ortografia contemporânea, corrigindo, inclusive, o nome do poeta francês Charles Baudelaire. 
(...) É impossível a um francês germanizar-se espiritualmente, sem perder o equilíbrio. Podem dizer que isso não se confirma num Renan, não se confirma num Taine. É exato. Mas porque eles tiveram a força bastante para ser lógicos até o fim, despiram-se do patriotismo como de um preconceito inferior. Andaram mal? Eles o podiam fazer, porque para os grandes espíritos ainda é uma estreita pátria todo o Planeta (OC, vol. I, p. 66-7).

O cosmopolitismo de Nestor Vítor dessa primeira fase corresponde à defesa de uma arte não limitada por preconceitos nacionais, alimentados também por uma visão estreita de ciência, como ele já defendera anteriormente no estudo Cruz e Sousa. Além de Veríssimo, o seu livro A Hora e esse texto em particular, "Os Desplantados de Maurice Barrès", parece ter como pano de fundo também os artigos de Araripe Júnior, como os que constituem o Movimento literário do ano de 1893, publicado em livro em 1895.

De forma mais ampla e mais compreensiva, Araripe Júnior buscou interpretar o sentido do "decadismo" no Brasil, mas, não menos "racista", seguindo os preconceitos correntes, acabou por rotular Cruz e Sousa como menos "civilizado" e até menos "nacional" em relação, por exemplo, ao poetas de feição simbolista da Padaria Espiritual do Ceará, a terra natal do crítico. Em suas conhecidas palavras, aparecem os sinais do preconceito de época.

De origem africana, como já disse, sem mescla de sangue branco, ou indígena, todas as qualidades de sua raça surgem no poeta em interessante luta com o meio civilizado que é o produto da atividade cerebral de outras raças.

(...)

Mais felizes, sob esse ponto de vista, foram os decadistas da Padaria Espiritual do Ceará. (...) Esse clube literário, sob formas excêntricas, ergueu o pendão do nacionalismo, sem quebra do cultor da arte universal (...) (ARARIPE JR., 1963, p. 147-51)

Ora, em Cruz e Sousa, Nestor Vítor quis reforçar o caráter "civilizado" da poesia simbolista e de seu maior representante, o poeta negro, da mesma maneira que em "Os Desplantados" ele busca negar mais uma vez o caráter tacanho das ideias cientificistas que também aparecem como nacionalistas, patrióticas, quando são, segundo ele, apenas preconceitos.

Ah se o mundo fosse propriamente isto, o amor à vida não passaria de uma coisa simplesmente idiota!

De uma coletividade assim, o que, realmente, em qualquer tempo podia sair? Não discutamos se a França está ou não está fazendo bancarrota; estes seus filhos tais é que não podiam deixar de falir.

Felizmente, eles são apenas criações de Barrès. Este tem os mais estreitos preconceitos da época sobre essa questão de hereditariedade, é crente de olhos fechados na tal cultura aplicada ao homem como um desenvolvimento da zootecnia, 
viciou-se profundamente nesse erro que consiste em andar utilizando no exame dos fenômenos sociais o mesmo método que se aplica no estudo dos fenômenos orgânicos, e em olhar sempre ao homem do inferior ponto de vista zoológico (OC, vol. I, p. 65).

Perspectiva estreita de Barrès que é confrontada com a perspectiva do "Poeta" na visão de Nestor Vítor, que é um gênio cujas circunstâncias só ressaltam a personalidade, em vez de ser sufocada por determinismos exteriores.

(...) Porque para o Poeta o recurso principal é o gênio. Riam-se os nulos, os medíocres de sua ingenuidade: ela é mais sábia do que todas as outras estreitas sabedorias do mundo.

Este não corre tanto risco pela falta de metal como pela deficiência de espírito. Perguntar se traz dinheiro para ficar tranquilo sobre a eficácia da ação que vimos oferecer ao mundo é, em última análise, característico de simpleza. Os grandes mendigos têm sido em geral os revolucionários da Terra. A injustiça do mundo, que sempre acompanha a miséria, fará do medíocre um criminoso, mas faz do superior um santo; ela o ilumina para redimir todos os seus outros irmãos pelo destino (ibidem, p. 67).

Assim, contra o nacionalismo tacanho, Vítor faz a defesa do cosmopolitismo amplo, universal, que inexiste nos "espíritos de segunda ordem”.

Mas se um Taine é susceptível de se prejudicar com tais influências, muito pior, é
claro, para os espíritos de segunda ordem. Estes podem mudar de pátria, mas lhes
seria fatal perderem o patriotismo propriamente. Um francês aborrecerá a França
tendo passado a amar a Alemanha; mas o que lhe seria impossível, sem que se lhe
abalasse profundamente o moral, é que ele deixasse de ser francês e alemão para
melhor amar todos os homens. Isso pede um coração muito vasto, pede muita
profundidade de alma. O cosmopolitismo é a anulação pelo menos de todo o civismo
nos espécimes inferiores (ibidem, p. 68).

Tal defesa, como disse, não é tanto a negação sistemática de todo nacionalismo. Vítor não é um internacionalista ideológica e politicamente falando. Conforme ele mesmo afirma no estudo, "combater-se radicalmente o espírito nacionalista seria deficiência lastimável de capacidade intelectual" (ibidem, p. 69). A sua posição, o seu cosmopolitismo, dirige-se para a arte, para a Arte com letra maiúscula, como ele insiste. Portanto, sua crítica ao nacionalismo tacanho combina-se à crítica ao cientificismo estreito que atuavam contra a autonomia da arte, dos valores estéticos que deveriam prevalecer na aferição das obras.

Sem ter de defender abertamente o simbolismo como a "melhor" estética ou a mais apropriada para o momento, ele se debruça sobre obras contemporâneas e europeias (Les Déracinés e Cyrano de Bergerac) para criticar os valores dominantes da literatura de sucesso 
do período e, com isso, responder indiretamente aos críticos literários brasileiros, afeitos a estes valores, dominantes e oficiais.

Com esse pano de fundo, que são as disputas no interior do campo literário brasileiro, é possível reconstituir o significado do seu discurso ideológico, não propriamente estético, mas voltado à defesa do "estético" e do "cosmopolita" contra o "científico" ou o "nacional" como critérios de valor da crítica literária brasileira.

Do mesmo modo, se é possível ler o texto de Vítor como uma leitura do espaço da crítica, também o é das possibilidades de criação literária da época. E é como parte de uma época em que a moral aparece tão fortemente para estabelecer contornos às obras de arte é que o crítico também assume um discurso moral e aparentemente contraditório ao de defesa do universalismo. Assim é que Vítor, já no final de seu estudo sobre o livro de Barrès, afirma:

\begin{abstract}
Chegados que estamos a este ponto, é preciso dizer agora que não foi para discutir a tese de Maurice Barrès, nem mesmo propriamente para criticar o seu livro, que eu empreendi este trabalho. Muitos outros tenho lido como este, onde há bom e mau, que não impuseram essa necessidade ao meu espírito. Foi sim principalmente para assinalar a decadência intelectual de que, vê-se pelas páginas desse livro, está a França atualmente a sofrer. É a constatação desse fenômeno que dá a $O S$ Desplantados um lugar excepcional; eles valem mais como um sintoma do que como uma obra de arte. Quando um escritor notável, representante de um grande povo, não pode reprimir gritos de angústia como este, fica-se impressionado sem querer, como que sentindo a aproximação de indefinidos cataclismos, de deslocações históricas que irão modificar profundamente a trajetória de toda uma civilização (ibidem, p. 79).
\end{abstract}

Entretanto, aliado a esse olhar moral, sobre o "sintoma de um fenômeno", o qual se choca aparentemente com a defesa da autonomia da arte, surge novamente e com mais força a crítica à perspectiva cientificista que impede o escritor (no caso, Barrès) expressar sua individualidade artística por meio da obra:

(...) porque o autor [Barrès] tem mais curiosidade do que simpatia pela vida e pelo homem, tem mais interesse teórico do que necessidade de desabafar nos seus tipos o seu próprio coração, porque ele é um dogmático, e como todos os dogmáticos um estreito (...) (ibidem, p. 72).

$\mathrm{Ou}$ seja, sem aderir completamente à perspectiva propriamente estética, de valorização da obra por seus caracteres internos, Vítor oscila entre a negação dos critérios que supostamente empobrecem o texto literário (a visão tacanha de nacionalismo alicerçada pelo determinismo cientificista) e a defesa de certos valores humanos, considerados por ele mais elevados moralmente (um universalismo humanista de que a arte seria uma representante). 
Em "H. Ibsen", Vítor reforça dois traços que já haviam sido esboçados em Cruz e Sousa: a noção de isolamento do artista e a realidade do poeta gênio, ligado a este isolamento. Como antes, ele oscila entre a defesa de critérios literários com os de valor extraliterários, criticando o meio social de produção da arte e de sua recepção.

Entre todos os estudos e textos publicados no período, "H. Ibsen" é o que mais apresenta uma leitura interna, propriamente literária, das obras analisadas, isso, sobretudo, porque se trata de um dos mais longos ensaios de toda obra de Nestor Vítor. Permitindo, por isso, intercalar julgamentos gerais em torno da produção do artista e de seus escritos com a análise propriamente "literária" dos textos do dramaturgo.

Consegue, por exemplo, construir classificações em torno da obra de Ibsen (entre as peças com concepção mais realista como Casa de Boneca, mais satírica como A União da Mocidade, ou mais filosófica como Brand), escolher matrizes temáticas, como a questão da "vontade", que parece refletir as leituras de Nestor Vítor em torno de Friedrich Nietzsche, sobre o qual escreve um pequeno artigo já em 1900, coligido em A crítica de ontem, ou interpretar o universo das personagens femininas do dramaturgo, avaliando a construção e o sentido destas personagens, ora para reafirmar a relação entre literatura e sociedade, que refletia a subordinação social e literária da mulher (rebaixada a um papel apenas “complementar" nas histórias e na vida), ora para apontar a superação dessa condição, como nos dois trechos que reproduzo abaixo a título de ilustração.

\footnotetext{
Mas quer umas quer outras são tipos clássicos, representativos do elemento feminino por uma forma genérica, no que nele existe de mais definitivo, mais independente da ocasionalidade e do meio. Até aí, pois, são tipos estes completativos na obra de Ibsen, como a mulher é naturalmente completativa na vida, não, porém, tipos centrais, tipos diretamente dirigentes (OC, vol. I, p. 155).
}

E:

N'Os Espectros, a emocionante Mme. Alving também participa dessas naturezas de mulher tocadas de certa masculinização. Também ela, no princípio da sua vida matrimonial tão silenciosa, tão passiva ante as brutalidades de um esposo crápula, indigno, assume, por fim, depois de tanta hesitação, os seus direitos de ser destinada a pensar, destinada a agir numa atmosfera de liberdade e consciência, de ser entusiasta por um ideal (ibidem, p.156).

Ligada a essa leitura mais "interna", centrada a interpretar e analisar os enredos, as personagens e até a estrutura das obras, ainda que limitado às traduções, já que, como ele mesmo afirma, só pôde ter acesso às traduções francesas, o crítico projeta linhas para refletir 
sobre a condição do artista e da arte, reforçando, assim, a diferença entre o que ele considerava a arte passageira e a grande Arte, "atemporal".

Com efeito, a ideia do isolamento do artista aplicado a Ibsen e o próprio isolamento como característica de algumas das personagens de suas peças atua de forma indireta para alimentar positivamente a autorrepresentação que os literatos simbolistas faziam de si e que a crítica oficial fazia deles (de "nefelibatas" descolados da realidade social, como sugeria Veríssimo e como afirmara Araripe em relação a Cruz e Sousa). Ao mesmo tempo, além de servir de imagem positiva, a noção de isolamento do artista realimentava o ideário do gênio romântico, que não é nomeado explicitamente por Vítor, mas que já existia no imaginário dos homens de letras brasileiros desde meados do século XIX, o que permitia, também indiretamente, criar uma tradição para os escritores alinhados ao simbolismo.

Tradição que o próprio Vitor denomina de "místico-simbolista" no artigo "Os Novos", de 1899, no qual ele liga os novos escritores brasileiros a uma plêiade de artistas europeus, cujas características diversas apenas poderiam ser agrupadas sob o signo do isolamento e da oposição ao mundanismo dos "concílios".

\footnotetext{
Os maiores tipos, Zola, Tolstoi, Ibsen, Bjoernson, dentre todos os contemporâneos, tornam-se justamente notáveis por serem os grandes isolados do fim do século. Todos eles são tidos como singulares, como extravagantes, como degenerescentes. Todos eles conspiram contra o interesse geral ou pelo menos contra aquilo que a grande maioria entende que o é. Com o povo as academias, toda a gente que anda em concílios, que representa coletividade notáveis, os escorra, e condena.

(...)

'O mais forte é quem fica só', disse Ibsen. Singular maneira essa de compreender a superioridade entre os homens! Não é maior o que consegue dirigir, o que consegue agremiar, o que consegue fazer atmosfera em redor, mas aquele que diverge, que escandaliza, que logra ser perseguido, que acaba na isolação.

(...)

Os artistas menores de olhar mais luminoso, de cabeça mais belamente arqueada que existem hoje, todos, como não podia deixar de ser, oferecem característicos idênticos aos destes gigantes trabalhados a grandes golpes. (...) Porque se há em Balzac a Comédia Humana, de que a Familia Rougon derivou deformada, há Luis Lambert, há Seraphita, de onde jorra em parte a corrente místico-simbolista atual (OC, vol. I, p. 286-7).
}

Como se vê, Nestor Vítor, mesmo antes de escrever o longo ensaio "H. Ibsen", já delineara a defesa dos "novos" por meio da comparação com os "grandes", os consagrados da civilização europeia. Algo que se assemelha à própria tática dos "combatentes" pela arte simbolista na Europa: buscar filiações que revelem a evolução da literatura para o ponto que representava o simbolismo. No conhecido manifesto de Jean Moréas, publicado originalmente em 1886, estabelece-se o "tronco" do simbolismo e se aposta nos "recém-chegados". 
Já se disse, no início deste artigo, que as evoluções da arte oferecem um caráter cíclico extremamente complicado por divergências; assim, para se acompanhar a exata filiação da nova escola, seria preciso remontar a alguns poemas de Alfred de Vigny até chegar a Shakespeare, até os místicos e ainda mais longe. (...) Entretanto, o Supremo Encantamento ainda não foi consumado: um labor perseverante e ciumento apela para os recém-chegados. (Jean Moréas. In: GOMES, 1985, p. 67).

Entretanto, mais do que atualizar os problemas de recepção da literatura simbolista, Nestor Vítor, ao tratar de Ibsen, busca reforçar, com outras palavras, o que já antes escrevera sobre Cruz e Sousa. Assim, a visão do crítico é que o gênio, o homem supra-humano, nasce de condições adversas e atua tragicamente como um combatente, elevando-se em função do meio que o obstaculiza.

Então novos embates; chovem-lhes raios à cabeça, e os heróis são vistos na pugna como um deus contra o qual se revoltasse o seu próprio universo.

(...) É preciso que eles sacrifiquem, transformem em matéria-prima para essa edificação, tudo quanto em si exista de estreitamente pessoal.

$\mathrm{Ah}$ ! e como as injúrias perdoadas, as injustiças recebidas com boa humildade de alma, e por outro lado como a boa coragem inexorável exercitada, não a seu favor, mas em favor alheio, de vítimas inultas, sobre almas de covardes e de vilões, ou então em favor do Ideal abstrato e simples, - simplesmente do Ideal, - como tudo isto lhes acumula materiais à porta, para esse subterrâneo e mágico salvatério, numa vassalagem medieval, tão tocante, como tudo é tão generoso na imprevista compensação! (OC, vol. I, p. 107).

O que inicialmente poderia dialogar com as concepções então correntes da arte simbolista, como a noção do poeta que "navega contra ventos e contra marés" ${ }^{74}$, afigura-se claramente como mais uma defesa do artista acossado pela recepção hostil. No cotejo entre os textos do crítico, particularmente, com a monografia Cruz e Sousa, a defesa contra o ambiente cultural hostil ganha um contorno bastante concreto. Quando o crítico analisa, por exemplo, Brand de Ibsen, alicerça sua interpretação da personagem central a partir de uma teleologia grandiosa, cósmica, que também correspondia a certas concepções que circulavam no final do século XIX.

(...) A derrota de Brand, considerada do alto é uma derrota exterior, simplesmente de aparência. Ele é tão vencido como é Prometeu, como Jesus, como são todos os mártires que sucumbem com o e pur se muove nos lábios. A quem é portador de um brandão e o aceita como um lábaro, a ignomínia não está em que as labaredas, assanhadas pela soturna ventania da noite, o atinjam, mas em que as apague a sua falta de resolução de heroísmo. (...) No mundo do pensamento, saber querer é ser glorioso, mas não é absolutamente obter o domínio.

74 "Mas se o poeta parte do símbolo para chegar à obra, é semelhante ao carpinteiro que equilibra uma viga sobre a cabeça e tem de vencer toda a força de gravidade de seu poema. Navega contra ventos e contra marés." (Maurice Maeterlinck, in: GOMES, 1985, p. 109). 
(...)

Mas desses deliciosos esmagamentos a alma sai sempre maior e melhor, porque, como diz Maeterlinck, mais avulta o homem quanto mais cresce nele o que se chama a ideia do infinito. Em nada o prejudica que na proporção em que esta se avolume decresça em seu espírito a ideia que ele fazia de si, como se ele tivesse lá no seu íntimo assentado e evidente sempre, que é errôneo o homem humilhar-se por isso, porque, em última análise, ele faz parte do infinito também (OC, vol. I, p. 127).

A leitura que Nestor Vítor faz da literatura contemporânea é então permeada pela filiação à corrente místico-simbolista, que, embora não seja religiosa, pôde confluir para a teleologia própria do cristianismo. A correspondência entre o homem e o "infinito" acaba por encontrar ressonância na leitura que então se fazia da poesia de Baudelaire e que críticos consagrados na Europa também difundiam, a exemplo de Ferdinand Brunetière:

(...) Ou, en d'autres termes encore, plus généraux, cela veut dire qu'entre la nature et nous il y a des "correspondances," des "affinités" latentes, des "identités" mystérieuses, et que ce n'est qu'autant que nous les saisissons que, pénétrant à l'intérieur des choses, nous en pouvons vraiment approcher l'âme. Voilà le principe du symbolisme, voilà le point de départ ou l'élément commun de tous les mysticismes, et voilà ce qu'il était bon que l'on essayât d'introduire, comme un ferment nouveau, pour la faire lever, si je puis ainsi dire, dans la lourde masse du naturalisme (BRUNETIÈRE, 1888, p. 218).

Desse modo, mais uma vez, Nestor Vítor reúne, ao mesmo tempo, referências diretas ao mundo civilizado europeu (por meio das escolhas e das análises que desenvolve) e referências indiretas à situação dos literatos e da produção da nova arte no Brasil. O heroísmo dos artistas isolados que tendem ao "infinito" pode ser lido sob a perspectiva dos escritores isolados que necessitavam de uma compensação "espiritual" para as derrotas imediatas no meio cultural.

Ainda sobre a noção do artista isolado, do gênio incompreendido, Vítor acaba por refletir também a concepção do artista que age por instinto, o que poderia lembrar vagamente a noção de artista-vidente de Arthur Rimbaud.

(...) O poeta vem para ser a alma das almas comuns, a representação de cada uma delas que viva num estado latente, que não possa reconhecer-se, evidenciar-se por si ante si própria.

Bem pode ser que a obra de Ibsen tenha obedecido aos seus instintos de artista, que ela seja, quase toda, resultante, nos seus grandes traços, de impulsos involuntários a que ele se entregue sem os querer sujeitar a uma análise rigorosa e fria. No artista o instinto é que principalmente merece fé (OC, vol. I, p. 150-1). 
Segundo Gomes (1985), ao comentar a carta de Arthur Rimbaud ${ }^{75}$ sobre o artistavidente, existe uma diferença entre a concepção do jovem poeta e as concepções anteriores, românticas e platônicas.

\begin{abstract}
Mas é preciso estabelecer diferença entre a missão oracular do poeta, segundo pressupostos platônicos e/ou românticos, e o perseguido por Rimbaud. Tanto para Platão quanto para Shelley, poesia é algo que independe da Vontade (...) Rimbaud, ao contrário, não exclui a vontade do processo criativo: 'o desregramento de todos os sentidos' é racional. O poeta tem o controle da sua loucura, que somente passará a dominar-lhe a razão no fim do processo criativo (...) Com isto, ele se diferencia do romântico que não tinha o controle do processo criativo, pretendendo fazer da poesia algo que independia da vontade (GOMES, 1985, p. 49).
\end{abstract}

A diferença de concepção que Álvaro Gomes vê entre o artista romântico e o artista vidente, cuja apreensão pode estar na base de certa reflexão de Nestor Vítor, talvez deva ser buscada a partir da situação social do literato e do público brasileiros.

O "impulso involuntário", a sobrevalorização do "instinto" e mesmo do sobrenatural ${ }^{76}$ correspondem à própria interpretação que Vítor já fizera em torno de Cruz e Sousa, para quem a falta de meios, de recursos e de boa recepção só poderia ser respondida por obstinação: "Cruz e Sousa é um fanático da Arte, como as Santa Teresa são as fanáticas da Religião" (OC, vol. I, p. 18). Ou seja, a aproximação com a noção romântica de gênio ocorre menos por uma identificação com o ideal de artista, naturalmente deslocado do meio ${ }^{77}$, e mais por uma imposição social que colocou o mais importante representante do simbolismo como um "deslocado"78. Nesse sentido, a identificação entre o artista isolado e o gênio romântico

75 Carta a Paul Demeny, escrita em 1871 e reproduzida em A Estética Simbolista (GOMES, 1985, p. 47-48).

76 Vejamos, por exemplo, esse trecho do ensaio sobre Ibsen, em que o crítico aponta uma progressiva aproximação com o místico e o mistério na obra do dramaturgo: "Entretanto, contraditoriamente na aparência, aquelas estreitas preocupações fatalistas relativas a essa questão de hereditariedade, de atavismo, que amarguram o Ibsen da Casa de Bonecas, d'Os Espectros, vão se esbatendo e cedendo lugar às intuições que lhe foram anteriores, provindas de sua crença em uma equidade universal. Desde O Pato Bravo que lhe vamos acompanhando os olhos em peça por peça, das que se lhe seguem, e o vamos vendo de cada vez mais atento às relações misteriosas das coisas entre si, às causas e às consequências, inevitáveis, de confranger, de arrancar lágrimas tantas vezes, mas ao mesmo tempo falando-nos de um ritmo sublime.

$O$ Pequeno Eyolf, então, parece todo ele feito de um sonho, parece escrito por um médium que estivesse todo ouvidos às vozes de Além, e ao serviço de forças estranhas que lhe guiassem o braço, a sorrir e a soluçar em torno a si (...)" (OC, vol. I, p. 164).

77 É possível pensar na aproximação que se fez entre o artista romântico e seu descolamento com a realidade social capitalista, marcando assim um conflito que isola o artista e impõe uma espécie de dever quase apostólico. Conferir, nesse sentido, o livro Revolta e Melancolia, estudo de Michael Lowy e Robert Sayre sobre romantismo e o capitalismo nascente. Ou, em termos mais gerais, na aproximação com o conceito bastante difundido do gênio romântico, como explica Nunes (1993): “(...) a ideia do gênio se pluralizou à época do Romantismo. (...) É que, altivo, incompreendido e distante, o poeta romântico impõe-se, intimado pela inspiração que o visita, a tarefa universal de legislador do reino dos fins espirituais intangíveis (...)" (NUNES, 1993, p. 62).

78 Nesse sentido, também a situação social do literato em fins do século pode aproximar, em termos genéricos, o artista romântico e o artista simbolista, na dissociação mais radical com o público que se "mundaniza". 
coloca-se menos a priori do que a posteriori, em função da situação social do literato diante da recepção brasileira.

Assim também, para Nestor Vítor, a "Intuição" aparece como mais central do que o processo criativo racional porque, por um lado, ele adere já à concepção de Maurice Maeterlinck $^{79}$ que separa o símbolo preconcebido, que pode ser lido como "alegoria", e o símbolo propriamente dito, descoberto, "encontrado" de forma passiva pelo poeta, e, por outro, porque a obra de Cruz e Sousa, principal referência literária do simbolismo brasileiro, não poderia, segundo o nosso crítico, ser produto direto do meio, não poderia logicamente ter brotado do contexto cultural brasileiro, visto como estreito. Portanto, a noção de artista resvala mais fortemente para a concepção romântica, mística, porque parece corresponder à experiência observada, como ele afirma na monografia Cruz e Sousa:

(...) Para Cruz e Sousa o indivíduo é ou não é, sem que ele possa admitir termos intermediários entre o ser e o não ser, desde que se fale de espíritos.

E a Arte, como ele a compreende, Arte pela Arte, independente de paixões que a escravizam, que façam dela o seu veículo, inferiorizando-a, tirando-lhe o caráter de sua independência suprema, Arte que é vida e que é morte, que é chama e que é néctar, Arte sacerdócio, Arte abstração absoluta e decidida loucura, essa é o seu domínio, essa é o seu mundo, é o seu alimento e o seu sono, é o seu sonho e a sua realidade exclusiva.

Compreende-se, um homem assim tem por força de se fazer um apóstolo perigoso e arrebatador, tem de ser uma força intensa e cega da causa que o destino tenha subordinado à sua fé e ao seu entusiamo, à sua loucura e à sua intrepidez absurda (OC, vol. I, p. 28).

Há, nesse trecho, a um só tempo, a aproximação com a noção de gênio romântico, de vate, de apóstolo, como, por exemplo, figura nos textos de um Gonçalves de Magalhães ${ }^{80}$ e a defesa da autonomia da arte diante das contingências do tempo, do espaço geográfico, e das "paixões" passageiras. Apenas em relação à arte universal, ao cosmopolitismo da arte

Conforme aponta Merquior: “(...) em princípio, e em contraste com o autor clássico - o escritor romântico é um solitário; e por causa dessa marginalidade é que ele será levado a adotar constantemente o tom da profecia: o profeta é sempre um outsider, um censor isolado da humanidade transviada." (1977, p. 52-53). Daí o "fanatismo" pela "Arte" e sua aproximação com as "fanáticas da Religião", como apontara Nestor Vítor em relação a Cruz e Sousa.

79 Conferir o texto "O Símbolo", de Maurice Maeterlinck, presente na parte "Textos Doutrinários" do livro $A$ estética simbolista. Segundo Gomes (1985): “(...) Maeterlinck persegue um Simbolismo espiritualista ao extremo (...) Isso porque acredita que o mundo seja ordenado segundo leis misteriosas, a que o homem deve estar submisso (...)" (GOMES, 1985, p. 110).

80 Sem dúvida, a introdução ao livro Suspiros Poéticos e Saudades, de 1836, bem como o poema "O vate" deste livro deveria ainda ecoar nas concepções dos homens de letras dos oitocentos. Conforme afirma Luciana Stegagno-Picchio, “(...) o fato é que esse túrgido Gonçalves de Magalhães, ébrio de individualismo romântico, possuía como poucos entre os seus coevos o sentido da missão do vate" (STEGAGNOPICCHIO, 1997, p. 166). 
relativamente autônoma que um artista como Cruz e Sousa poderia surgir na visada de Nestor Vítor.

Ao longo do ensaio sobre Ibsen, a noção de isolamento do artista, de gênio instintivo, funciona, assim, tanto para explicar internamente o movimento interpretativo que Vítor faz do dramaturgo norueguês e de suas peças quanto para confirmar a interpretação que ele já havia lançado sobre o simbolismo e os simbolistas brasileiros, isolados em seu tempo e em seu meio, guiados apenas por uma força "interior" que os animava, como supostamente seria a atitude de Ibsen, expressa em sua obra.

Quando os grandes centros da civilização anulam-se sob a influência de um materialismo pequenino e covarde, futilizam-se, tornam-se ridículas Bizâncios, meticulosas e míopes, faz bem olhar para este vulto, que divisamos ao longe, no extremo norte-europeu quase como que de pé sobre o polo, a vizinhar com os astros, solitário, amargo, mas sonhador e bom. Ele se nos afigura um farol gigantesco que através das névoas caliginosas da noite, e sob o uivo de uma tormenta ainda longínqua, consegue projetar sobre o mundo inteiro um raio de sua luz guiadora.

Assim esbatida pela distância e pelos obstáculos, essa luz tem a cor amargurada dos eclipses, confunde-se com a agonia de um crepúsculo noturno. Mas quando o mundo atravessa uma hora de náufrago, quando a vida inteira no Planeta é uma trágica incerteza, um mal contido soluço, o ridente é profano, o estardalhante é impiedoso, é absurdo, só o que é compassivo, mas grave, pode ser fraterno e leal (OC, vol. I, p. 165).

O "artista-guia" e as obras "matrizes" são noções essenciais dessa primeira apreensão do simbolismo e de sua defesa em nossa terra. Por essa perspectiva, o estudo da obra de Ibsen funciona como "requintado" argumento em favor dos artistas brasileiros que àquela hora encontravam-se isolados defendendo princípios contrários ao da arte influenciada pelo "materialismo pequenino e covarde". Servia, por esse prisma, como contraponto à situação constrangida dos simbolistas brasileiros.

Desse modo, os dois textos aqui comentados do livro A Hora são centrais para consolidar uma imagem da arte e de filiações do simbolismo que as fases seguintes do pensamento crítico de Nestor Vítor modificariam: a imagem do isolamento do artista e do universalismo e cosmopolitismo artísticos. Parece-me, inclusive, que boa parte da historiografia em torno da figura de Nestor Vítor cristalizou-se a partir das representações que surgem nessa primeira fase, cujo livro A Hora, bem como a introdução ao livro de Silveira Neto, o estudo sobre Maeterlinck e a monografia inicial sobre Cruz e Sousa deixam patentes. Vejamos como a introdução ao livro de Silveira Neto e o estudo dedicado a Maurice Maetelinck contribuem também para essa imagem em torno do crítico. 
Em "O Elogio do Luar de Inverno", introdução de Nestor Vítor ao livro de Silveira Neto de 1900, coligida em A Crítica de Ontem, o crítico busca diferenciar a estética simbolista da romântica, apontando, particularmente, certa contenção no tratamento dos temas e uma atitude de "amargo misticismo", próximo de um "ascetismo de nova espécie" (OC, vol. I, p. 267).

Em Silveira Neto, mais do que em Cruz e Sousa, o crítico quer enxergar maior reflexão, maior sutileza, atitudes trágicas também, mas amortecidas por uma postura de “ascetismo intelectual”, “de gabinete”. Imagem que ele já utilizara no prefácio ao livro $A$ Hora ("a existência de gabinete").

\begin{abstract}
Apenas, jamais encontrareis nela [na alma do poeta] o estardalhante das alegrias francas, o explosivo das decisivas revoltas. Há atitudes trágicas, ameaças que enregelam as veias. Mas ouvi o que nesses momentos mais culminantes se diz: a voz é cava e principalmente amortecida não se sabe por que invisíveis abafadores. Vede que ações são as que decorrem desses inícios que vos deixaram numa expectativa ansiosa: simples espectros de ação, como de um Byron de gabinete, movimentos pela metade, idas e voltas de Hamleto a cismar (OC, vol. I, p. 268).
\end{abstract}

Essa atitude mais supostamente racional e contida de Silveira Neto talvez representasse um leve giro de Nestor Vítor em relação à postura que antes apontara em Cruz e Sousa. A "Intuição" parece aqui dar lugar a um regramento mais racional dos sentimentos e pensamentos, o que confirmaria também a adoção dos paradigmas da arte simbolista expressa por Jean Morèas em 1886, antes citado. É assim que o crítico faz a avaliação estética do livro de poesias do paranaense, apontando o preciosismo da forma sem, no entanto, negar certa "alucinação" nas imagens.

Fiel a um número dado de sentimentos, restrito por isso a um dado número de ideias, o autor do Luar de Inverno não ostenta, porque não podia ostentar, uma abundância de estilo que seria contraditória com o seu ascetismo intelectual: ele tem um número também limitado de recursos para a expressão dessas ideias e desses sentimentos.

(...) Ele é de um sentir veemente, menos pelo ímpeto do impulso do que pelo doloroso, pelo perturbador da sensação; e a forma por que ele sente é a mesma que tende a empregar para comunicar-se com o exterior: seu estilo é bárbaro e alucinante, - de uma construção convulsa, quase epiléptica, carregado de imagens febris, dolorosas, pungentes. (...)

Juntai a isso a preciosidade dos epítetos, o misticismo do vocabulário em geral, e antes de o lerdes vos será fácil prever que livro abrupto e singular é este que vos espera (ibidem, p. 269).

Dessas características, expostas ainda de forma vaga e impressionista, resulta um estilo que se alinha bem aos manifestos simbolistas que, na Europa, desde o texto de Jean Moreàs alcançam popularidade no início dos anos de 1890. Para Nestor Vítor, advém daí uma 
espécie de modernidade de Silveira Neto que, herdeiro da tradição parnasiana, soube avançar mais para as conquistas propriamente simbolistas.

\begin{abstract}
Além disso, por um lado, um ascetismo aristocrático na escolha das rimas, raras e ricas quase sempre, mas, por outro, num desdém convulso por fáceis melopeias, numa impaciência enferma de quem sofre demais para ir ajustando a uma medida só a expressão dessas ânsias, - um parti-pris decisivo, senão pelo verso livre, pelo menos pela assimetria da estrofe, por uma multiplicidade de metros a que o poeta muitas vezes recorre quando menos se espera (ibidem, p. 269).
\end{abstract}

Essa liberdade formal na composição dos poemas dialoga, por conseguinte, com a tradição simbolista europeia, de radicalização na composição rítmica dos poemas, que aqui pouco encontrara recepção. Silveira Neto teria avançado mais que Cruz e Sousa no tocante à forma, ainda que menos que Mário Pederneiras, que será visto em seguida no artigo de Nestor Vítor de 1906, e menos ainda que o poeta Murilo Araújo que estrearia em 1917, bastante elogiado por Nestor Vítor e que conformaria a ala espiritualista do modernismo, também se ligando à revista Festa.

O diálogo de Vítor com a literatura europeia pode encontrar ressonância na análise que Gomes (1985) faz ao falar sobre os principais textos e manifestos ${ }^{81}$ que trataram da relação entre o verso e o ritmo na estética simbolista, defendendo mais liberdade em relação ao que se estava estabelecido nos tratados e manuais:

(...) Para Mockel, o ritmo dependerá do 'sentido gramatical do verso', ou seja, a medida formal nascerá ou será imposta pelo significado. Como em Eugênio de Castro, podemos pensar novamente num ritmo adequado a cada verso, em oposição à ideia de um conjunto exterior de ritmos registrados nos manuais prosódicos (GOMES, 1985, p. 123-4, grifo meu).

A recepção do ideário simbolista europeu funcionava, por um lado, para atacar mais uma vez o atraso das concepções reinantes no país (preso às fórmulas parnasianas) e para, por outro lado, eleger, nesse texto sobre Silveira Neto como em outros textos que surgirão nos anos seguintes, sobre Emiliano Perneta, Dário Veloso e Rocha Pombo, um outro centro cultural para o país que não a já sitiada capital, o Rio de Janeiro. Assim, ao mesmo tempo,

81 Recorrendo aos "Textos Doutrinários", reunidos por Álvaro Cardoso Gomes (1985), podemos encontrar ao menos três referências que provavelmente chegaram direta ou indiretamente a Nestor Vítor e a outros homens de letras do período. O primeiro, o supracitado manifesto "O Simbolismo", de Jean Morèas, de 1886, o prefácio de Eugênio de Castro ao livro Oaristos, de 1890, e a obra Propos de Littérature, de 1894, de Albert Mockel, crítico e poeta simbolista belga, que também escrevera em 1898 sobre Mallarmé, por ocasião da morte do poeta francês e que colaborava regularmente com a prestigiada Mercure de France. 
Vítor atacava as concepções passadistas de parnasianos e naturalistas e o ambiente cultural em que estes reinavam, elegendo a capital do Paraná, como outro centro "civilizado".

E nisso [publicar livros estranhos ao meio cultural brasileiro] não fazem mais os novos escritores daqui do que acompanhar, uns por instinto natural, outros por imitação consciente, o movimento universalizado por todos os centros do mundo em que a arte encontra hoje uma digna representação.

Por toda parte é o que se vê: ou epígonos de velhas escolhas, numa chôcha e fanha orquestração de pronunciada ressaca, a bordarem cediços cairéis em torno de velhos temas que já perderam sua razão de ser, e que por isso conseguem hoje apenas entusiasmo oficial presidido (...) (OC, vol. I, p. 271).

E:

Porque Silveira Neto é paranaense, como eu.

Quase que todo o Luar de Inverno, foi composto em Curitiba, onde ele reside, centro literário que depois do Rio é hoje o mais notável no Brasil, no que respeita às belasletras propriamente ditas. (...)

Silveira Neto, Emiliano Perneta e Dario Veloso são até hoje os que entre todos mais eloquente documentação nos têm oferecido da superioridade de seu espírito (ibidem, p. 268).

Por esse quadro, é possível avaliar que as análises propriamente literárias que Vítor realiza nesse estudo, apontando características, interpretando versos, erguendo princípios estéticos da poesia de Silveira Neto servem a dois propósitos: definir e clarificar a literatura simbolista brasileira, relacionando esta aos padrões europeus, considerados civilizados (os “centros do mundo”), e atacar mais vez a crítica e a criação literária dominante, oficial, do período, realizando ele próprio a eleição de outros autores, valores e mesmo ambientes, como a capital do Paraná ${ }^{82}$, para representar a "hora" contemporânea, "o movimento universalizado por todos os centros do mundo".

O que há aí, nesta postura, de política literária, de propaganda, de espírito de coterie, e o que há de defesa de um cosmopolitismo que permita horizontes mais amplos, logo, que se insira na defesa da maior autonomia da arte, ancorada no próprio intercâmbio de obras e de sua renovação constante, não é possível dissociar.

Como um crítico secundário, seria impossível a Nestor Vítor, em particular nessa primeira etapa de sua produção, apenas voltar-se às questões internas dos textos ignorando as disputas no interior do campo literário brasileiro. A chamada "transição" para a crítica

82 As referências ao Paraná e, particularmente, a Curitiba seguem por toda a sua obra, colocado como o segundo centro cultural em que se desenvolveu amplamente o simbolismo. Os textos da seção "Homens e temas do Paraná" do terceiro volume da Obra Crítica deixa evidente essa defesa "regionalista" da importância do Estado. 
estética, que tanto Candido quanto Tristão de Ataíde (Alceu Amoroso Lima) ${ }^{83}$ apontam em Nestor Vítor, não seria dada apenas pelas transformações internas na tradição literária ocidental mas pela própria dinâmica do campo literário brasileiro e o lugar que o nosso crítico ocupava em seu interior, como se pode ver pelas exigências ou demandas que ele busca responder para legitimar a literatura simbolista no país.

Por último, no diálogo que Vítor estabelece com a "civilização" e com o pensamento europeu sobre a nova arte, é importante avaliar o estudo que realiza sobre a obra de Maurice Maeterlinck.

$\mathrm{Na}$ "Introdução" ao livro A Sabedoria e o Destino, traduzido por Nestor Vítor, há dois movimentos já anunciados antes, o das definições da literatura simbolista e de suas filiações com a tradição literária ocidental.

Primeiro, ao tratar sobre Maurice Maeterlinck, Vitor já considera o autor consagrado nos meios intelectuais europeus. A obra que ele traduzira era de 1898, mas, de 1889 ao ano da tradução (1900), o escritor belga já produzira onze livros. Sua consagração na Europa apenas aumentaria nos próximos anos, tendo sido indicado cinco vezes para o Prêmio Nobel de Literatura (1903, 1904, 1909, 1910 e 1911) e, enfim, sendo vitorioso na última indicação.

Ao contrário do que acreditou Nestor Vítor, o artista por ele tão reverenciado não permaneceria na história da literatura ocidental com as mesmas glórias do início do século. $\mathrm{O}$ próprio Maeterlinck não se manteria fortemente atrelado à estética simbolista do início ao fim de sua carreira. Foi, como muitos escritores criticados por Vítor, um artista do seu tempo, como assegura Otto Maria Carpeaux (2008):

Maeterlinck talvez não tenha sido um poeta muito maior do que Van Lerberghe e Rodenbach; mas disse na hora certa a palavra certa que o mundo inteiro compreendeu porque era uma palavra muito vaga, intensamente poética sem chegar a ser grande poesia. Assim, não foi injustiça para a literatura belga receber, na pessoa de Maeterlinck, a suprema homenagem da Europa burguesa: o prêmio Nobel. Maeterlinck está hoje meio esquecido como dramaturgo; só Pelléas et Mélisande sobrevive graças à música de Debussy. Não merece, porém, o mesmo esquecimento a poesia lírica de Maeterlinck; menos a poesia simbolista de Serres chaudes do que

83 Sobre a colocação de Candido, ela já fora referida em capítulos anteriores. Aparece em "Literatura e Cultura de 1900 a 1945", ensaio compilado em Literatura e Sociedade, no qual o crítico afirma: "A passagem do historicismo à estética se esboçava na obra de José Veríssimo, o mais literário dos nossos velhos críticos, e nessa fase é tentada pela crítica de inspiração simbolista e idealista, representada sobretudo por Nestor Victor, mas que não chegou a amadurecer e realizar-se" (CANDIDO, 2006, p. 123). Sobre a afirmação de Tristão de Ataíde, ela aparece originalmente em 8 de novembro de 1936, alguns anos após a morte de Vítor. O crítico colocava Nestor Vítor como o iniciador da "fase estética" da crítica literária brasileira. Assim se pronuncia: "Fase estética. Começara esse novo espírito da crítica literária com uma figura da mesma geração que aqueles três [Sílvio, Veríssimo, Araripe], mas que participara já de um movimento literário moderno, para o tempo - o Simbolismo." (Alceu Amoroso Lima, in: MURICY, Andrade. Panorama do movimento simbolista brasileiro, vol. 1, 1973, p. 330). 
as Douze chansons, uma das obras mais estranhas da poesia francesa: parecem baladas, mas são canções populares de tipo medieval, cheias de angústia mística, tipicamente germânicas, numa língua francesa algo diferente (CARPEAUX, 2008, p. 2136-7).

Se a Primeira Guerra acabou soterrando a literatura finissecular na Europa, o simbolismo também não estaria a salvo. Contudo, a aposta de Nestor Vítor era justamente nas obras de maior aproximação com a estética simbolista para alicerçar mais uma vez o destino dos escritores alinhados a esta estética aqui no Brasil.

Como no estudo sobre Ibsen, Vítor busca fazer um arrazoado de toda a obra do escritor belga. Concentra-se naturalmente nos livros que poderiam transmitir os valores que buscava para consolidar a imagem de nosso simbolismo, sobretudo Serres chaudes, que é o livro mais comentado e analisado no texto, além do próprio La Sagesse et le destinée.

Neste, como nos estudos anteriores de nosso crítico, é que se percebe também com maior clareza o que poderia significar a adjetivação que ele recebeu na historiografia literária: o de crítico "simbolista", particularmente, pelo estilo de escrita marcado pelas metáforas e imagens construídas com o objetivo de sugerir poeticamente características, aspectos temáticos ou formais mais do que descrevê-los ou analisá-los. Esse traço de estilo, com certeza, vai se enfraquecendo ao longo da obra, de modo que pouco se vê, por exemplo, nos escritos a partir da Grande Guerra. Os artigos da década de 1920, marcados pela demanda da empresa jornalística são mais curtos, objetivos e também mais incisivos na crítica ou no elogio. Como afirmei, a imagem de "crítico simbolista", ligada à primeira fase de sua produção, foi a que ficou mais fortemente marcada nos manuais de história da literatura e da crítica literária, omitindo-se assim a própria transformação no estilo do escritor.

Vários exemplos podem ilustrar esse estilo "simbolista", o qual, mais do que um estilo de escrita, favorecia também a mensagem a ser transmitida, saturando o texto, a partir da forma, da defesa da estética simbolista. Para explicar, por exemplo, o desenvolvimento do artista, Vítor usa diferentes imagens, como as que remetem ao processo de dormir e despertar, ou à floração. Vejamos:

Nossas obras de estreia são em geral menos nossas do que dos espíritos formados com que primeiro nos fomos encontrando pelo caminho. Há um profundo dormir, a princípio, no íntimo do nosso ser. (Sono, aparteara Hamleto, ou sagrado pavor, pungente agonia do Horto antes da irrevogável resolução de caminhar para o sacrifício?) Só muito a custo podemos ir correspondendo por forma autêntica ao nosso próprio chamado. Por isso os pensamentos que vêm vindo depois da primeira floração trazem aquele vigor, aquela seriedade, aquele ar definitivo de heróis prisioneiros que enfim rebentaram cadeias e caminham para o posto que lhes cabe, 
de onde desertou, só com o sonoro eco de seus passos, como um enxame de importunos insetos, a turbamulta dos que tinham conseguido partir primeiro, não por seu valor, mas pela astúcia, pelo dolo, que se casam com a inferioridade (OC, vol. II, p. 4)

Além de uma linguagem carregada por imagens, metáforas, este e outros textos do período conformam a visão idealista, a-histórica em torno da arte que fixaria também uma imagem sobre o simbolismo brasileiro.

(...) O maior poeta, como o maior pensador deste mundo, são incapazes de vos fazer doação, propriamente, de uma ideia ou de um sentimento qualquer. É preciso que o que eles vos dizem já viva em vós, muito antes disso, sob uma forma latente, no estado de limo capaz de se tornar animado para que voz impressione, vos abale, produza em vós o deslumbramento de um súbito clarão e se revista de todos os ilusionismos próprios a vos fazer crer no fenômeno interior de uma revelação (ibidem, p. 4).

Para explicar o surgimento de Serres chaudes, que corresponde, por extensão, ao "florescimento" da nova literatura, a simbolista, Vítor combina a linguagem metafórica com uma interpretação da tradição literária que, mais uma vez, comprovaria a convergência para o momento de maior idealização na arte, no "mundo intelectual".

\footnotetext{
Estas Serres Chaudes, por exemplo, de M. Maeterlinck. São toda a sua obra, num tenro estado germinal embora, com a frescura dos abrotos, dos sóboles, de tudo o que está em rebento, que representa uma virgem promessa, prenunciando o que há de vir na linguagem enigmática e cândida que tinham os pássaros sagrados às mãos dos áugures romanos.

Antes de tudo, como este livro nos fala do mundo intelectual de onde vinha e para que se voltava no momento, dentro de uma hora toda crepuscular, toda peregrina, principalmente ao olhos do círculo heroico em cujo meio ele fora produzido.

(...)

Mas, por isso mesmo que o realismo alcançara sua mais alta expansão, o outro lado da montanha, negro e talhado a pique, começava a atraí-lo, vertiginoso e fatal. A humana necessidade de pura idealização desiludira-se da fórmula romântica, mas já procurava com o desespero, com a dispneia dos cegos que perdem o caminho de casa, um outro avatar que a tornasse compatível com a doce luz da existência (ibidem, p. 07).
}

Em seguida, tratando da tradição sob a qual se erguera o simbolismo de Maeterlinck, Nestor Vítor elenca todos os principais e mais conhecidos "mestres" do novo movimento: Baudelaire, Verlaine, Rimbaud, Mallarmé. Objetiva mostrar os elos entre os "mestres" do passado e os combatentes do presente. Reproduzo a seguir um longo trecho que traduz o tipo de interpretação que Nestor Vítor constrói para o simbolismo europeu e que ele busca transpor para nossa literatura por meio desses caracteres gerais, de negação do mundanismo, 
de ascetismo intelectual, de oposição às tendências realistas, mas também às românticas, propiciando o surgimento de um "novo" próprio àquela "hora".

(...) Mas Verlaine, dizíamos, vivendo Rimbaud, já firmara, no que respeita à forma exterior, as consequências inevitáveis depois de Baudelaire e a que o voyou adolescente atingira de um vôo com a perturbadora intuição misteriosa do gênio. À rigidez marmórea da estética parnasiana sucedera um balancear mais largo, mais livre, mais natural, no verso e na estrofe, de acordo com as tendências simbolistas que de cada vez mais se acentuavam. E, sobretudo, vivendo a vida, a sua dele, que lhe era própria, fora fazendo dos dias agros que lhe concedera o destino moedas com que comprava aos Aquerontes da Terra o direito de transpor mais uma curva sombria, de sofrer mais um pouco à luz deliciosa do existir consciente, ao mesmo tempo que ia deixando para trás, por passar mais desembaraçado e mais pronto, todas as pretensões, e por isso também, não já somente blasfêmias, mas todas as queixas, todos os estados d'alma que traduzissem tédio, amargor, incontentamento de revel, por um lado, e por outro qualquer um modo de ser mundano.

Villiers de L'Isle-Adam, por esse tempo, fechava os olhos, alucinados de tanto sonho; mas ainda ficava Stéphane Mallarmé. Estes dois tinham também influenciado por modo decisivo na feição do momento. Eles não contrariam propriamente a doçura resignada do velho frequentador de hospitais, revestida da forma de uma reconversão a ortodoxias ingênuas, que havia tanto tempo, já, tinham governado o mundo, mas completaram esse modo de ser intuitivo do Mestre com o produto de uma existência inteira de labor espiritual, sobre os livros, e do embevecimento com que acompanhavam o evolver da vida interior que lhes era própria. As tendências místicas de um e de outro os tinham levado ao estudo de todas as épocas mais caracteristicamente espirituais, que do fundo dos séculos estivessem acenando numa correspondência misteriosa a esta de hoje, agora em tentativa de formação. Dessa vida de ascetismo beneditino trouxeram ambos na fronte uma doce palidez severa, e no gesto esta sobriedade aristocrática que traduz ausência completa de pretensão a domínios grosseiros, mas por preocupações transcendentais e excelsas. Daí uma nobreza de linhas, um caráter grave, à força de ser natural, em um e noutro, que vieram modificar a atitude verleniana, propondo tacitamente um tipo menos romântico, mais do momento, de uma ação menos instintiva, mais consciente, baseada numa cultura de intensidade mais impositiva (ibidem, p. 8-9).

Aqui se pode verificar novamente a oscilação entre a primeira análise que realiza da obra de Cruz e Sousa e aquilo que denominei de leve giro para uma perspectiva mais racionalista, mais próxima dos manifestos conhecidos do simbolismo europeu. Giro provavelmente propiciado pelas leituras que deve ter realizado entre 1896 (escrita da monografia Cruz e Sousa) e o início do século XX. A série literária que ele reconstrói passa por uma postura de depuração dos artistas, que vão abandonando as pretensões mundanas e adentrando no ascetismo intelectual e nas tendências místicas e espirituais "de todas as épocas". Predomina novamente uma visão teleológica, como se a nova arte, a simbolista, representasse um objetivo final dos grandes artistas, dos gênios, e que o percurso de uns teria levado necessariamente a estágios superiores a arte de outros, de maneira que ao final predominaria uma "cultura" mais elevada, "mais impositiva". Poderia lembrar aqui a 
descrição hipotética que Paul Valéry desenvolveu, em 1939, em torno dos jovens escritores que se lançaram no movimento simbolista em fins dos oitocentos: a atitude ética que unia os combatentes da alta "Torre" da arte, em uma espiral de sonhos e de ascese ${ }^{84}$.

Com efeito, não é estranho que a temática dominante em Maeterlinck, encontrada por Nestor Vítor, reverbere a que também apontara ao falar de Ibsen, ambas centradas em questões éticas do homem diante da "Destino".

Todos os outros dramas de Maeterlinck giram em torno do mesmo eixo. Que eu conheça: As Sete Princesas, Peléas e Melisando, Aladina e Palomida, Interior, A Morte de Tentagilas, Aglavena e Seliseta. O Destino, e a atitude do homem em face do Destino, eis o que em cada um deles constitui o que se pode chamar a preocupação central e dominante (ibidem, p. 17).

A interpretação, no entanto, não soa absurda, pois apreende algo das preocupações metafísicas que conformavam essa vertente da literatura na época. Ela afigura-se aliás próxima à avaliação que o crítico Otto Maria Carpeaux faz de parte da obra de Maeterlinck: "São tragédias fatalistas, menos shakespearianas, como proclamou Mirbeau, do que de um Ibsen simbolista, 'diálogos mudos' entre vítimas de um destino fatal, místico" (CARPEAUX, 2008, p. 2137).

De fato, a leitura crítica de Nestor Vítor não foi de todo fruto de um puro subjetivismo impressionista, porque soube, na análise sistemática que fez de autores que lhe convinham, captar traços gerais que podia utilizar para difundir a arte simbolista e assim arrefecer os obstáculos oficiais erguidos pela crítica naturalista e pela produção majoritária de prógonos e epígonos do naturalismo e do parnasianismo.

Com efeito, a divulgação da obra de Maeterlinck funcionava para educar, diria, o público, para ampliar a recepção das obras da vertente místico-simbolista que legitimariam todo o esforço seu e de seus companheiros desde os anos de 1890 no Brasil.

(...) Maeterlinck é um escritor místico, ou um místico que é escritor; mas ele não é o que se costuma chama tout court, sem adjetivação, um escritor. (...) E ainda, é preciso dizer-vos, de suas páginas até aqui se eliminou o que havia propriamente de mais vertiginoso. Este escrito, se não se destina ao vulgo, propriamente, é em todo caso um trabalho de vulgarização: aspira conquistar simpatias para o herói de que pretende ser um pálido elogio. Não fala, pois, de preferência àqueles que já se tenham encontrado com ele face a face e o tenham sabido amar sem órgãos

84 Segundo Valéry: “A renúncia, vocês sabem, está muito próxima da mortificação. Mortificar-se é procurar, de uma maneira dura, e mesmo dolorosa, edificar-se, construir-se, elevar-se até um estado que suspeitamos ser superior. O desejo dessa elevação, dessa 'ascese', pronunciando-se no campo da arte, tornando-se uma condição de vida do verdadeiro artista e da produção das obras, esse é o fato totalmente novo e a característica profunda que se observa em todos os participantes autênticos desse Simbolismo ainda sem nome" ("Existência do simbolismo". In: Variedades, 2011, p. 68). 
intermediários; destina-se, com especialidade, aos que a estes se possam imediatamente seguir (ibidem, p. 20-1).

Assim, respondendo ao que Luiz Costa Lima (1981) chamou de a "dispersa demanda" do público leitor do século XIX, Nestor Vítor busca vulgarizar a obra de escritores alinhados a uma determinada vertente do simbolismo. Não há, no entanto, como se viu, uma completa coerência entre todos os princípios que ele tem elencado em torno da arte simbolista. Ora a eleição da "Intuição", da "alucinação", ora o esforço racional para encontrar o ritmo e o verso adequados; ora a revolta e a luta contra o meio cultural restrito, ora a comunhão pacífica com as forças naturais e quase cósmicas que se comunicam com o artista, com o poeta, com o gênio.

As oscilações nas definições e nas avaliações de Nestor Vítor refletiam simplesmente as vicissitudes da própria difusão do movimento simbolista pelo país e pelo mundo. $\mathrm{O}$ estudioso Henri Peyre em seu A literatura simbolista analisa a situação geral da "floração simbolista" como parte do movimento geral das artes e da literatura:

\footnotetext{
É natural que na literatura e nas artes, como na vida, uma geração que se procura e audaciosamente se propõe a mudar o mundo percebe bem mais claramente aquilo que reprova e ataca do que aquilo que positivamente quer levar a cabo. (...)

Não se trata, pois, de submeter os simbolistas nascidos entre 1850 e 1865 , que por 1885-1895 frequentaram tal café, tal cenáculo, o escritório de tal revista, a alguns rígidos princípios filosóficos ou estéticos. Seria demasiado fácil coligir frases de seus manifestos para pô-los em contradição com seus camaradas e, aliás, com eles mesmos.

(...) O único terreno comum de entendimento dos simbolistas foi o da sua denúncia do naturalismo, nos seus aspectos mais provocantes, na teoria, e nos mais sórdidos, nas obras (PEYRE, 1983, p. 54-5).
}

A representação, por exemplo, recorrente na historiografia literária brasileira, de Nestor Vítor como o maior herdeiro de Cruz e Sousa e seu maior defensor não pode ser lida como uma adesão irrestrita a todo o credo simbolista ou a uma defesa cega de toda a produção que o poeta morto deixou. Como buscarei demonstrar mais à frente, a avaliação de Vítor sobre a obra de Cruz e Sousa nos anos de 1910 e 1920 é bastante diferente da que realizou nesses seus primeiros anos de produção crítica. Fora "o terreno comum de entendimento dos simbolistas", que é o de "denúncia do naturalismo", a qual, no caso brasileiro, foi particularmente importante dado o prolongamento das estéticas naturalista e parnasiana entre nós, a avaliação crítica em torno do simbolismo e dos escritores simbolistas alterou-se ao longo do tempo. 
Para além da interpretação de Paul Valéry (2011), para quem não existiu uma estética simbolista, talvez a explicação para as mudanças nos textos críticos de Nestor Vitor esteja ligada ao que próprio Valéry constatou como a resistência "natural" da "vida" aos altos anseios dos artistas, ou o que poderíamos chamar, nessa perspectiva em torno do campo literário, como as dificuldades imanentes de consagração em meio cultural concreto, historicamente determinado por forças que os produtores individuais não conseguem nem controlar nem compreender completamente.

\begin{abstract}
É preciso confessar que o Simbolismo teve outros inimigos além desses críticos que só perturbam talentos sem resistência. Teve contra si suas próprias virtudes e seu ideal ascético. Por outro lado, as necessidades da vida, a idade que chega e torna cada vez mais penoso, e às vezes mais escuro, um destino devotado severamentedemais a um culto puro demais, a ambição de estender a esfera de uma fama que a delicadeza das obras necessariamente restringe e reduz à admiração do pequeno número; finalmente, a chegada das novas gerações que não experimentavam mais as mesmas impressões, não encontravam mais o mesmo sistema de circunstâncias e que a lei fatal de existir e de criar, por sua vez, coagia a ignorar ou a negar os desejos, as razões, as avaliações dos 'simbolistas'; tudo isso devia trazer uma dissolução, uma corrupção e, em certos pontos, uma vulgarização do espírito que tentei apresentar (VALÉRY, 2011, p. 76-7).
\end{abstract}

De fato, o que Paul Valéry descreve pode ser lido sob a chave das dificuldades e das disputas no interior do campo literário brasileiro. Situações ligadas à história do indivíduo e dos seus pares que conformam regras que se modificam com o tempo e com o espaço, que se alteram com novos atores e novas demandas. Um campo literário que possuísse maior autonomia em relação às demandas econômicas e políticas poderia, por exemplo, exercer maior "força" para assegurar aos seus membros determinadas posturas e práticas, garantindo assim maior coerência nas ideias.

No caso de Nestor Vítor, talvez a primeira fase de sua produção crítica, que também é seu primeiro momento de apreensão, definição, divulgação e defesa do movimento simbolista, tenha sido a sua fase mais frágil, porque esteve constrangido pela dinâmica interna do campo literário, o qual não lhe conferiu consagração imediata, de modo que mudanças e "giros" mais intensos aparecem nos momentos posteriores, revelando maior transformação em suas concepções do que se poderia prever com base apenas nos seus primeiros textos.

Como se verá nas seções seguintes, a defesa do simbolismo, nos momentos posteriores, passará menos pela forma saturada de imagens metafóricas, por um estilo "simbolista" de crítica, ou pela defesa de altas aspirações artísticas, e mais pelas descrições e 
avaliações concisas, muitas vezes mais céticas e mais sarcásticas do que a sua juventude pôde oferecer nesse primeiro momento.

Em um jogo invertido, o período de menor espaço de tempo, a primeira fase, é o que consagrou Nestor Vítor, a longo prazo, como o "crítico simbolista" ou o "crítico do simbolismo", enquanto boa parte da sua produção, voltada às obras e aos escritores da belle époque, que passa pelos chamados "pré-modernistas" até os primeiros modernistas, é quase desconhecida, ignorando-se as transformações do crítico que acompanham as próprias transformações no meio cultural brasileiro na República Velha.

\subsection{Momento de transição em torno do simbolismo}

Os artigos da segunda parte de A Crítica de Ontem selecionados por Nestor Vítor já encaram a sua produção após o regresso de Paris. Trata-se, de fato, de uma nova etapa, ainda não completamente definida, em que o simbolismo começa a ser considerado não mais como a estética do presente, da "hora", mas uma estética já enfraquecida. O primeiro texto em que isso fica patente é o artigo de avaliação do livro de poesia de Mário Pederneiras, Histórias do meu casal, de $1906^{85}$.

Nestor Vítor reconhece que já há uma "retirada", ou melhor", uma "debandada completa" da geração dos "simbolistas e decadentes". Avalia que Mário Pederneiras é um epígono da escola e que seu novo livro apresenta os "sinais exteriores" da estética. Características que ele não avalia negativamente, mas que refletem o enfraquecimento do movimento no período.

Provavelmente a percepção do arrefecimento não é fruto apenas da observação da produção literária a que ele tinha acesso no Rio de Janeiro, mas também do que pôde observar nos três anos de sua estada em Paris. Segundo Michel Décaudin (1960), a chamada "crise dos valores simbolistas" pode ser encarada a partir de 1895, quando houve uma difusão e ao mesmo tempo diluição dos valores simbolistas pela cultura literária. Os poetas e as revistas

85 Este artigo ilustra também um equívoco que a historiografia realizou em torno do pensamento de Nestor Vítor. O artigo é citado por Wilson Martins (A crítica literária no Brasil) como posterior ao opúsculo Farias Brito, de 1917. O autor afirma: "Dois anos depois, referindo-se a Mário Pederneiras, não ignorava o caráter efêmero da escola literária com que sentira maiores afinidades" (MARTINS, 1983, p. 330). O artigo, coligido em A crítica de ontem, de 1919, havia sido escrito em1906 e refletia, como veremos, uma visão do simbolismo diferente da que se expressa no texto Farias Brito, o que evidencia a leitura parcial e, nesse caso, mesmo equivocada da periodização da obra de Nestor Vítor pela historiografia literária. 
que assumem a estética simbolista, embora continuem existindo e se multipliquem, revelam ser menos "revolucionários" do que acreditavam ser no início do movimento.

S'il y a encore des poètes symbolistes en 1900, il n'y a plus de symbolisme. Plus rien qui ressemble à l'esprit qui régnait em 1893-1894 dans les cercles littéraires.

(...)

Le Mercure de France multiplie les articles sur les poètes symbolistes; mais Pierre Quillard, titulaire de la chronique de poésie depuis le début de 1898, y montre le plus grande éclectisme et s'intéresse avec sympathie à tous les cheminements de la poésie; et les poètes publiés dans les pages du Mercure représentent toutes les tendances (...) . L'Ermitage s'oriente plus nettement à partir de janvier 1899 vers un idéal de beauté familière qui puisse réunir Jammes, Paul Fort, Vielé-Griffin, Verhaeren (DÉCAUDIN, 1960, p. 102).

Se é possível estabelecer um paralelo, a fase de "combates" tanto na Europa quanto no Brasil havia se esgotado. Essa parece ser a percepção de Vítor no que se refere à estética simbolista. Daí a sua maior abertura, como já me referi, à literatura brasileira sem os "preconceitos de escola" que ele apresentara na sua etapa inicial de produção e a busca por novos referenciais para a sua crítica. Não é à toa que publica um longo artigo sobre a poesia de Alberto de Oliveira em 1906 assim que retorna de Paris quando, provavelmente, entrou em contato com as mudanças no panorama de recepção e produção da poesia simbolista.

Podemos vislumbrar, por exemplo, pela primeira vez, no artigo sobre Mário Pederneiras, a possibilidade de encontro "harmônico" entre as tendências neocristãs e o "sistema de ideias" do simbolismo.

Penetre-se mais a fundo e há de ver: o sistema de ideias que aqui se encontra é também legitimamente o da escola, dando-lhe a sua colaboração característica um neocristianismo que por ser vago não deixa de ter feição própria e de exercer irradiante influência na imaginativa e mesmo na ação do poeta, de modo até singularmente lógico e harmônico (OC, vol. I, p. 392).

Tal indicação pode ser a chave para explicar a futura adesão ao grupo dos espiritualistas de matriz católica que aparecem com força em fins dos anos de 1910 e que serão defendidos por Vítor ao longo dos anos 20 como uma alternativa ao grupo dos "andradistas" do movimento modernista brasileiro. Ainda que essa "adesão" não seja ao catolicismo, o qual ele rejeita, é uma aproximação "aceitável” para o grande público como ele afirma ainda no artigo e que parece expressar a sua posição definitiva sobre a questão.

Do conjunto dessas aprimoradas páginas transpira um sentimento religioso, até definitivamente cristão, que, no entanto, nada tem das ladainhas cabotinas, dos blom! Blom!, dos miserere, por troça ou por moda, que andaram fazendo a caricatura rimada da liturgia católica nas páginas insossas de nefelibatas sem valor, ou nas de 
poetas de mérito, mas faltos ora de sinceridade, ora de gosto ${ }^{86}$. O sentimento religioso que aqui se encontra é simples e sério, desses que despertam com a educação do berço e que a família é tão apta a manter (ibidem, p. 394).

Ou seja, a aproximação com o "sentimento religioso" aparece menos como a adesão aos rituais ou aos dogmas da igreja e mais como um sentimento constitutivo da cultura nacional, o que permite explicar a recepção do público em relação às obras e que servirá, mais de uma década depois, para que Nestor Vítor afirme o caráter estranho do naturalismo em nossas letras, já que não corresponde ao "nosso" jeito de ser, impregnado de sentimentos religiosos, espirituais.

Por essa via, o crítico consegue também estabelecer uma ponte com o simbolismo de que foi representante e, no mesmo movimento, realizar o resgaste de uma literatura de coloração romântica, aparentemente mais afeita à "constituição" brasileira, e que ele enxergava em várias produções contemporâneas, como essa de Mário Pederneiras.

Segundo ele, "Mário Pederneiras representa o simbolismo, senão desiludido, pelo menos experimentado, e por isso atenuado, adaptado, aceitável” (ibidem, p. 394). E o que ele compreende como exatamente "aceitável"? Os temas e as formas sentimentais de expressão poética, parte de certa tradição romântica.

\begin{abstract}
Não sei quem não saia, de fato, emocionado ao terminar a leitura das Histórias do meu Casal. Simpatiza-se de modo tão legítimo com o sentimento de felicidade e de paz que nos vem da primeira parte, No Vale da Ventura, ama-se tão carinhosamente a natureza bem dotada e escolhida deste moço, que tem a boa força de se fazer feliz entre os elementos simples e sãos que um lar pacífico na sua obscuridade oferece, quanto depois, No País da Saudade, que é a segunda parte do livro, compartilha-se das suas amaras provações, no reverso tristemente natural das coisas, mas antes de tudo porque ele expõe esse reverso com simplicidade fundamente sugestiva, numa correspondência perfeita, e na verdade de bom gosto, com a modéstia, com a medida que soubera manter ao falar-nos do sorrir encantador dos olhos de seus filhos e da embebida contemplação do seu carinhoso espírito de pai (ibidem, p. 394).
\end{abstract}

Depois de uma profícua produção em torno da estética e do "sistema de ideias" simbolista de sua fase inicial (1896-1902), Nestor Vítor precisa buscar, dentro do universo de possibilidades inscritas em nossa tradição literária, aquelas que melhor corresponderiam aos seus impulsos iniciais. Aqui, em 1906, ele começa a fazer isso: um sentimento religioso e

86 Nesse extrato, Wilson Martins também enxerga uma crítica indireta à vertente da poesia simbolista de caráter abertamente católico que se manifestava nos textos de Alphonsus de Guimaraes e que confirmavam também o caráter de sua crítica como parcial: "Claro, a surda rivalidade e rancorosos olhares entre os partidários de Cruz e Sousa e os de Alphonsus de Guimaraens fazem parte da história pitoresca de nosso Simbolismo, mas há alguma coisa mais na atitude de Nestor Vítor e é uma certa concepção paroquial ou grupal da vida literária, vista frequentemente como o choque infindável e permanente de hostilidades tribais e sob as espécies de uma luta pelo prestígio" (MARTINS, 1983, p. 333). 
moral difusos e um "renascer" de certos valores românticos, os quais, em conjunto, unidos pelo passado e pelo presente de nossa série literária, parecem distantes dos valores do parnasianismo/naturalismo ao qual ele se opôs fortemente pelas circunstâncias de surgimento de sua obra. O "sistema de ideias" de Vítor começa a se alterar para preservar, no interior do campo, a oposição aos valores ainda dominantes tanto na crítica quanto na criação literárias.

A recomposição dos valores de sua obra frente ao enfraquecimento do movimento simbolista dependia, no entanto, de condições de produção que o próprio Nestor Vítor provavelmente ainda não podia vislumbrar.

Em artigo do mesmo ano de 1906, “Os Emancipados por Fábio Luz”, já citado por mim, ele se vê em volta de um "grupo heterogêneo" de escritores, aos quais ele afirma não ser antipático, porque o momento parece ser de enfraquecimento das oposições mais duras do passado e de maior ecletismo, tal como Michel Décaudin também avaliara nas palavras reproduzidas há pouco.

Relativizando os combates de outrora, Vítor avalia, nesse último artigo sobre o romance de Fábio Luz, que não há, de fato, mais enfrentamento à "sociedade burguesa", sendo "membros normais" todos os escritores de diferentes matizes. Constata também a "indiferença do público pelas letras" que permite, ao menos, que os diferentes escritores “prosperem na trégua” (ibidem, p. 402).

Em outras palavras, em um momento de indefinição de novos valores artísticos, de forte mundanismo da belle époque, de enfraquecimento das estéticas oitocentistas, o literato ou o crítico produzem mais livremente, ainda que sem as "paixões" e a recepção mais fervorosa de uma década atrás.

Passados alguns anos sem produção crítica, como já descrevi nos capítulos anteriores, em 1911 Vítor escreve um longo artigo sobre uma poetisa já falecida, Auta de Sousa, cujo livro Horto saia em $2^{\mathrm{a}}$ edição e que teria feito sucesso nos primeiros anos do século XX por ter recebido o elogio e o prefácio de Olavo Bilac.

Percebe-se, neste artigo, "Horto, poesias de Auta de Sousa", coligido também em $A$ Crítica de Ontem, o fortalecimento dessa postura aparente em 1906: defesa de uma literatura neorromântica e de fundo religioso.

Assim, após uma descrição da breve biografia da escritora, que faleceu aos 25 anos, o crítico enaltece o livro por ser "um livro de moça, e de moça brasileira, feito, antes de tudo, de meiguice e de ais, voltado, principalmente, para as almas femininas, e destas traduzindo os 
sentimentos" (OC, vol. I, p. 411). A partir daí, passa a estabelecer as relações com a tradição romântica e a apontar os traços neorromânticos em vários poemas transcritos integralmente.

Sob os traços que mais o caracterizam, não conheço na nossa literatura outro livro feminino que se possa equiparar ao Horto. A alma de Auta de Sousa é irmã gêmea mas é da de Casimiro de Abreu, dentro das modalidades do nosso momento. Numa e noutra o mesmo leit motiv, que vem a ser a tristeza e a dor, a mesma doçura de cordeiro diante do irremediável da sorte, a mesma vibratibilidade, poder de sugestão idêntico, - ambas essas ditas almas fazendo lembrar harpas eólias ressoantes ao sabor do vento (ibidem, p. 412).

O fundo cristão da poesia neorromântica, voltado a certo clima moribundo (a tuberculose da jovem) e propriamente passadista (os temas voltados às "criancinhas", ao "tempo fugidio", às “dores alheias", aos "passarinhos", etc.), ganha destaque na apresentação e avaliação que Nestor Vítor vai fazendo ao longo do artigo, demonstrando assim a própria valorização do crítico em relação ao tipo de literatura que ele começa a considerar como apropriada depois do enfraquecimento da literatura simbolista.

E a poesia ela vota, acima de tudo, à vida mística. Jesus, e aquela Madona, Senhora que impera docemente nos corações católicos, são o seu refúgio e os seus ídolos, que lhe recebem e lhe enxugam as lágrimas, transfundindo em bálsamo o que era fel (ibidem, p. 414).

Esse ressurgimento passadista dos temas românticos conclui em nacionalismo identitário em 1911, privilegiando o conteúdo da obra em relação à sua forma, talvez condenável.

Nesse amor, porém, justamente, é que consistiu, mais do que em tudo, a superioridade de seu ser, daí é que lhe veio o estímulo necessário para fazer-se a dolorosa poetisa do Brasil. Por isso é que um homem que as lê, as páginas do Horto, no recesso do seu gabinete, sente-se irmão daquela sofredora tão boa, e comove-se com ela, humanamente, achando-se em tal companhia bem longe do mundo. Se ele é tímido ou se é um vaidoso, pode, depois disso, calar, até, aos outros homens o nome daquela que lhe inspirou esse inefável sentimento de confraternidade, falando-lhe a linguagem da dor, pela qual nós todos nos prendemos uns aos outros, reconhecendo a nossa origem comum. Talvez o faça com receio de perder alguma coisa da autoridade que acaso tenha, de comprometer algo de seus créditos intelectuais, tratando-se de uma autora que nem sempre a crítica há de achar impecável, dentro dos cânones, ou que nem sempre satisfaça as altas exigências relativas ao valor substancial da arte. Se ele, porém, nada pretende comunicando-se senão mostrar-se sincero e leal, será mais um a dizer ou a escrever, referindo-se àquela adorável poetisa, que, com o Horto, esta terra conta mais um livro que é órgão legítimo da expressão solicitada pelo nosso lirismo, com mais uma coletânea em que há versos que são versos, poesias que traduzem a poesia verdadeira, com mais umas páginas que há de ficar como um soluço da dor humana e representando uma nova justificação como a vida pode ser sempre dignificada pelo talento, pela bondade e pelo amor (ibidem, p. 420-1). 
A ideia de que exista um "legítimo lirismo", ou um legítimo "modo de ser" brasileiro ganhará cada vez mais força nas posturas críticas de Nestor Vítor a partir de então. O que revela uma mudança essencial de perspectiva em relação à fase anterior.

Se antes, apesar dos contornos éticos que assumia a sua crítica, ela estava voltada à defesa da arte, da autonomia da arte diante de critérios exteriores, de preconceitos de época, agora, mesmo avaliando detidamente alguns poemas, como, de fato, ele o faz transcrevendo os versos da poetisa, a sua análise está subordinada a um ideal de literatura nacional, que se choca diretamente com o cosmopolitismo da fase anterior.

Com efeito, a defesa do simbolismo exigia uma postura cosmopolita, dado o caráter repetidamente denunciado de "imitação" ou "importação" artificial da estética para nosso território. O sinal precisava ser invertido pelo crítico do simbolismo: valorizar o que se denegria, denunciando o caráter tacanho de nossa crítica nacional.

A aproximação, efetuada nesse início dos anos de 1910, com uma estética neorromântica não poderia reabilitar, imediatamente, os modelos literários do passado. Era necessária alguma mediação. Daí ele próprio se escusar antecipadamente, afirmando que “tratando-se de uma autora que nem sempre a crítica há de achar impecável, dentro dos cânones (...)", ainda assim deva ser defendida porque corresponderia ao "nosso lirismo".

De fato, após essa mediação, ele termina o artigo exaltando o "legítimo pendor" de nossa "terra" que deveria ser incentivado com esse tipo de poesia, de literatura. Delineando, desse modo, a sua própria postura crítica como de incentivo a uma certa imagem do país e de sua cultura que se afastavam, a partir daí, bastante do que representou o seu cosmopolitismo inicial.

A defesa do simbolismo permitiu-lhe, ou melhor, como disse, exigiu dele uma abertura para o universal, que concretamente eram a literatura europeia e seus referenciais; a falta dessa defesa, tendo em vista o esgotamento da estética, leva-o ao mesmo horizonte do nacionalismo literário que vicejava em nossa tradição desde o romantismo.

Com a leitura que realiza, a partir de então, dos simbolistas e de seus epígonos, ele não mais buscará definir a estética simbolista nos termos abstratos, vagos e idealistas como antes ele o fizera. Ao contrário, tornará mais concreta a filiação do simbolismo à tradição romântica brasileira, não mais discursando em torno de uma arte do presente ou para o futuro e sim 
sobre a conexão entre os escritores que se filiaram ao simbolismo e a tradição literária nacional.

Como se trata ainda de uma fase de transição, não só de sua crítica, mas dos próprios rumos que a literatura brasileira assumia, vemos que os artigos que escreve, nesse período, sobre Emiliano Perneta (em 1911 e em 1914) e sobre Cruz e Sousa (em 1914) trazem ainda a marca de uma dualidade: há a afirmação de caracteres do simbolismo, considerado já enfraquecido e a busca de ligação com a tradição literária brasileira, cujos contornos são os que assinalei: o nacionalismo literário e os temas do romantismo brasileiro.

\subsubsection{Cruz e Sousa e Emiliano Perneta: reavaliação do simbolismo a partir dos poetas}

A dualidade na abordagem desses dois importantes simbolistas brasileiros, Cruz e Sousa e Emiliano Perneta, nesses primeiros anos de 1910, revelam um período de transição e de incertezas. Não se trata propriamente de uma rememoração passadista, como ocorrerá a partir de 1917, mesmo que o primeiro texto sobre Emiliano Perneta, de 1911, trace um histórico da formação intelectual de Vítor e da própria formação do simbolismo no interior do qual Perneta se desenvolvera. O passado aqui ainda está subordinado ao presente e à reflexão do que pode ser a grande Arte, a arte renovadora, tal como ele propunha antes.

A questão que se coloca, nesse momento, ao ler as direções que Vítor executa no interior de seus textos, liga-se à falta de perspectiva mais ampla que pudesse alicerçar uma tomada de posição mais consistente como antes fizera. Sem essa perspectiva, volta-se, ainda que sem o declarar abertamente, à defesa de temas que remontam parte de nossa tradição literária romântica, sem, contudo, esquecer da "modernidade" que representou a estética simbolista.

Os dois artigos que Nestor Vítor escreve nesse período sobre Emiliano Perneta estão reunidos em A crítica de Ontem e intitulam-se "Emiliano Perneta" (1911) e "Pena de Talião" (1914). O primeiro escrito em função do lançamento de Ilusão, livros de poemas, e o segundo em referência ao texto dramático homônimo do poeta paranaense.

Conhecidos há 20 anos, Vítor e Perneta trocaram correspondência no ano de 1911 tratando do lançamento do livro deste último. Nas cartas, percebe-se que a estratégia de Vítor era a mesma que aparentemente tentara utilizar em relação a Cruz e Sousa: escrever um bom 
estudo introdutório da obra do poeta para que ajudasse na recepção da obra. Como ele próprio afirma em carta de 18 de julho de 1911:

\begin{abstract}
Esta é uma das grandes alegrias da minha vida: concorrer para a justa glorificação de mais um companheiro, tanto mais sendo daquele que primeiro me iniciou nos segredos da Arte que eu tenho podido apresentar. Vou ler-te e reler-te demoradamente. Não precipites a saída do livro. Quando eu tiver feito o meu trabalho te direi. Tu depois há de vir ao Rio. É preciso que te faças conhecer pessoalmente pela geração de agora. Combinaremos isso, espero eu, quando eu for até a nossa Curitiba $^{87}$ (Nestor Vítor, in: CAROLLO, 1975, p. 311).
\end{abstract}

Com Cruz e Sousa, a estratégia de leitura e recomendação prévia foi inútil; o poeta morreu em 1898 e a publicação da monografia Cruz e Sousa ocorreu apenas em 1899, sem que o objetivo imediato de melhorar a recepção da obra Evocações se efetivasse. O mesmo aconteceria em relação ao livro de Emiliano Perneta, não porque este morreria, já que isso só ocorreu em 1921, mas porque outros escreveram antes sobre o livro do poeta paranaense. Nestor Vítor estava, segundo ele próprio, sobrecarregado com a finalização do original de Paris, que seria publicado no mesmo ano.

A apresentação do companheiro de longa data objetivava, em primeiro lugar, divulgar o poeta nos círculos cariocas dado o seu "exilamento" em Curitiba. Para isso, o crítico utilizava-se de seu próprio capital individual de relações, pelo que já produzira antes e pelo lançamento no mesmo ano, o de 1911, de Paris, que logo receberia boa acolhida da crítica oficial, por exemplo, de Sílvio Romero, e já em 1913 teria uma segunda edição. Daí que seu estudo sobre Perneta, publicado originalmente em $O$ País, apresente em sua primeira parte um resgaste da história de formação intelectual de Nestor Vítor e o papel que Perneta teria desempenhado nesta formação. A rememoração do passado está subordinada ao objetivo de inserir o poeta no meio carioca: "Fui-lhe apresentado então, e aí nos ligamos para sempre, sendo sua amizade uma das mais influentes na minha vida" (OC, vol. I, p. 423).

A segunda parte do artigo que também apresenta traços de rememoração reafirma defesas feitas anteriormente: o papel do Paraná, de Curitiba, e o da renovação intelectual que representou a estética simbolista em nossas terras. Sem muitas novidades, reafirma também o credo da Arte pela Arte e o papel missionário dos poetas.

Emiliano Perneta, na verdade, viera para a cruel e gloriosa missão de renunciar o mundo, na Arte pela Arte, caso em que esta exige ser escrita com maiúscula para exprimir a coisa a que realmente corresponde.

87 Procedi à atualização ortográfica para facilitar a leitura. 
(...) 'Nós só conquistamos', disse Goethe, 'aquilo que sabemos desejar com ardor.' Seu único sonho era, afinal, o sonho de um verdadeiro e intransigente poeta (ibidem, p. 427).

Na reafirmação do credo estetizante há, porém, uma diferença que já se nota na citação acima. Nos textos da primeira fase, Nestor Vítor, aderindo aos modismos do movimento, utilizava fartamente as letras maiúsculas e não se justificava em relação a este uso, tornado-o natural. Aqui, ele já justifica o uso, o que revela distanciamento, o mesmo que se aprofundará no estudo Farias Brito de 1917, no qual ele também se referirá ao uso das “maiúsculas" pelos simbolistas, mas então representando este uso como uma convenção que se afigurava como formalismo "árido". Aqui, ainda, em 1911, preserva o respeito por essas convenções, relacionando-as a naturezas excêntricas, como a de Emiliano Perneta ou como a de Cruz e Sousa, como fará no artigo de 1914.

Como nas colocações da primeira fase, Vítor ainda preserva a imagem idealizada do artista que luta contra o mundanismo, contra a vulgaridade, conforme afirma:

(...) em tudo [que produziu Perneta] um característico se encontra: a completa ausência de vulgaridade, embora à custa de extravagância muitas vezes, mas sempre - o que é melhor, - representando o produto de nobre desinteresse, sempre orientado para um fim ideal (ibidem, p. 428).

Do mesmo modo, resta ainda a imagem do poeta contra o mundo cuja obra representa "a sua digna resposta (...) porque é um título definitivo de triunfo, bastando ele só por si para coroar toda uma vida" (ibidem, p. 430).

Essas reafirmações do credo simbolista estariam em conformidade com a imagem de "crítico do simbolismo" que a Nestor Vítor foi fixada, contudo ele próprio busca atualizar a sua representação pública ao denunciar certo passadismo da estética à qual se filia Perneta e os problemas que tal filiação carrega no presente.

Pela feição que lhe é própria, prendendo-se à corrente desses que se chamaram os satanistas, os decadentes, os simbolistas, já vem um pouco fora do seu tempo, neste instante em que, embora aproveitando a evolução efetiva que aqueles nobres sonhadores realizaram na poesia, tentam os recém-chegados de valor libertar-se de todas as fórmulas rígidas que as escolas sempre trazem consigo, de todos os preconceitos próprios aos que adotam pontos de mira invariáveis, de todas as deficiências, de toda a estreiteza, características dos que esquecem o natural propriamente dito, trocando a vida, a liberdade, a espontaneidade por um mundo artificioso e pela atitude, pelo ademane, pelo gosto que se adotam em círculos intelectuais de ocasião.

Ao abrir-se o livro e ainda no percorrer bom número de suas páginas iniciais como que se ouve o tinir da ferragem da escoa, sonido singular há dez ou quinze anos atrás, com seus dlem, dlim, dlom, e com o argentino rodar das esporas, ao refulgir 
dos capacetes de uns cavaleiros simpáticos, mas que davam a impressão de meio loucos, e passavam vertiginosamente, ainda mais pálidos do que de natureza, porque refletiam no perfil convulso o mole palor do luar (ibidem, p. 431).

O tom entre terno e caricatural demonstra o afastamento, o distanciamento que antes já se apresentava sutilmente. Depois desses parágrafos e de alguns sobre a estrutura rítmica dos versos, ele resolve o "constrangimento" de Ilusão filiar-se a um movimento "fora do tempo" com algumas páginas sobre a figuração do amor na poesia de Perneta. Justifica a análise do tema do amor na poesia do escritor por ela representar algo de nosso legítimo lirismo, como ele já delineara nos artigos antes referidos, sobre Mário Pederneiras e Auta de Souza.

Ora, o que representa na maioria de suas páginas a Ilusão é um diário de amor. Nesse ponto elas nos são bem patrícias, são bem meridionais, bem do trópico mesmo, indo da ternura desinteressada até a extrema lascívia, pelas mulheres.

Sob tal aspecto elas não participam de fato, por forma alguma, daquela atitude quase impassível de esteta exclusivo (...) (ibidem, p. 432).

Além do amor e suas variações "bem patrícias", Vítor elogia também os "versos simples, do mais seguro bom gosto" (ibidem, p. 438). Considerações bastante distantes das que fazia em sua primeira fase sobre o Verso-abstração de Cruz e Sousa ou o preciosismo de Silveira Neto, ou ainda a complexidade místico-heróica da palavra de Maeterlinck. O excêntrico e o requintado como marcas de distinção começam a ceder espaço para o já conhecido e para os critérios de "bom gosto" e de clareza, que figuravam na crítica, por exemplo, de José Veríssimo.

Ainda nessa fase sobrevivem os resquícios dos "mestres" da estética simbolista, de maneira que já nas últimas páginas, depois de enaltecer o tema do amor em Perneta, Vítor transcreva dois poemas, uma "joia verdadeiramente esquisita" (ibidem, p. 438), e outro com "laçadas de assimétricos versos" de "fundo trágico" (ibidem, p. 439) que servem para a associação com o poeta Mallarmé:

(...) não precisa mais do que ler estes dois últimos documentos para dar como existente a natureza de um raro artista em Emiliano Perneta. Ele faz lembrar nestes poemetos as poucas, mais imortais horas de graça que pequeninas peças surpreendentemente perfeitas atestam na obra de Mallarmé (ibidem, p. 438)

É, dessa maneira, em um movimento de retomada sutil de velhas concepções amalgamadas a um novo "sistema de ideias" que Vítor configura suas reflexões em torno do 
simbolismo e dos escritores simbolistas. De passagem, apenas localizarei o que parecia ser o desfecho lógico dessas considerações em torno do poeta paranaense.

No artigo "Pena de Talião", escrito após o início da conflagração da Primeira Guerra, Vítor faz o elogio da peça de Perneta reforçando os dois aspectos que já surgiam negativos no artigo de 1911: a personalidade do artista e a sua filiação ao simbolismo.

\begin{abstract}
Predomina um característico histerismo na complexão deste artista, mas o que o salva, contrabalançando tanto ou quanto essa condição mórbida a que está sujeito, é aquele 'furor pela beleza' de que na Ilusão ele nos fala. Ainda exagerado como seja até nesta paixão redentora, nessa paixão divina, ela é tão legítima em sua natureza, tão pronunciada, tão empolgante, que o desvia triunfalmente do perigoso redemoinho a que sua fisiologia tarda parece querer arrastá-lo. Salva-o pelo menos para fazê-lo gemer e soluçar encantadoramente, não raro arrebatadoramente, dandose até que, uma vez ou outra, ele consegue atingir a alta esfera de uma legítima e luminosa serenidade, em que descansa por momentos de bem-aventurança, caramente conquistada.

(...)

A intrepidez de seu satanismo e da sua volúpia talvez sejam as únicas coisas por que dele nos separamos, sem contudo haver falsidade ainda nesses seus aspectos, porque em última análise são coisas essas humanas (...) (ibidem, p. 463).
\end{abstract}

A serenidade alcançada apesar do "histerismo" da personalidade do artista e a separação com o "seu satanismo" comprovam a busca de Nestor Vítor por consolidar uma imagem de crítico não mais colada aos "nefelibatas" do passado. Novamente, a excentricidade e a loucura do artista, que pareciam condições aceitáveis e especialmente esperadas em virtude do meio e do tempo "excessivamente materialista" de outrora, agora são vistos como excrescências, traços que confirmam a diferença do artista frente aos demais homens, mas que, por si só, não valem “por uma obra”, como ele já dissera positivamente em relação a Cruz e Sousa.

Do mesmo modo, se a concepção em torno do artista se altera, a apreensão da estética simbolista, também. Ela já não mais está “fora do tempo", ela está encerrada.

É por isso que esta leitura ficará assinalando por modo singular o momento em que ela se realizou, quando nos achamos diante de fatos estupendos, que darão amanhã, forçosamente, outro aspecto ao pensamento humano e ao sentimento artístico. Esta foi, talvez, a chave com que se fechou no Brasil a obra fiel àquela tendência que na história literária destes tempos ficará amparada pelo prestígio e prejudicada pelas inconveniências de uma escola, - a escola simbolista, como se convencionou chamála (ibidem, p. 464). 
O artigo sobre Cruz e Sousa, também de 1914, além de ratificar o pensamento de fim do simbolismo, acrescenta, de forma flagrante, a adoção dos critérios naturalistas de crítica que antes eram por ele rejeitadas.

Começa o artigo "O Poeta Negro" com o repisar de crenças racistas e evolucionistas, que determinariam o papel do homem negro e o da sociedade sem “civilização" própria.

\footnotetext{
Cruz e Sousa, negro sem mescla, foi uma cerebração de primitivo genial, foi como que a revivescência de um núbio contemporâneo de Davi ou ao menos de Salomão, senão já educado à luz franca dos princípios mazdianos, mas que houvesse renascido no Ocidente e se desenvolvesse num meio cuja civilização é toda de empréstimo, já capaz de inspirar grandes requintes a um artista, porém no fundo por modo muito falseado e ingênuo (OC, vol. I, p. 465).
}

Talvez Nestor Vítor, em formulações como essa, demonstre ter assimilado de forma mais mecânica o cientificismo europeu do que outros críticos como Araripe Jr. ou Sílvio Romero, porque tanto um quanto outro buscaram adaptar a adesão aberta ao modelo naturalista às particularidades do país, utilizando-se de noções como obnubilação tropical (Araripe) e miscigenação (Romero), que correspondiam a um duplo movimento: o de idealizar os "padrões metropolitanos de civilização" e o de encarnar "reivindicações de autonomia e originalidade" (VENTURA, 1993, p. 38). Duplo movimento que parece não conformar a crítica de Nestor Vítor nesse texto crítico.

Parece-me que uma conversão tardia ao credo naturalista resvalou para uma adesão sem nuances, desvalorizando a própria experiência de contato entre a "cultura civilizada" de um lado e a não "civilizada" de outro, como figurava na obra dos críticos oficiais do naturalismo. Vítor repete, por exemplo, na citação acima, as considerações de Araripe Júnior expressas em Movimento literário de 1893, endossando as colocações de fundo racistas e mesológicas. Araripe afirmara:

(...) De origem africana, como já disse, sem mescla de sangue branco, ou indígena, todas as qualidades de sua raça surgem no poeta em interessante luta com o meio civilizado que é o produto da atividade cerebral de outras raças. A primeira consequência desse encontro é a sensação de maravilha. Cruz e Sousa é um maravilhado (ARARIPE JR., 1963, p. 147, grifo do autor).

O negro "sem mescla" lutando contra o meio é tomado pelas sensações, daí a caracterização de "maravilhado" postulada por Araripe. Vítor afirma nesse texto de 1914, após o parágrafo inicial transcrito: "Cruz e Sousa revela-se, como artista, sobretudo um 
sensual na acepção lata da palavra, o que é tão lógico tratando-se de uma natureza de primitivo, ainda mais se africano" (OC, vol. I, p. 465).

Se antes a crítica ao cientificismo alicerçava a defesa das singularidades de Cruz e Sousa, aqui a adesão ao naturalismo confere identificação com a recepção crítica inicial do poeta. Acaba por repetir ideias sobre o caráter do escritor e aproxima-se da crítica negativa ao seu estilo poético, feita também anteriormente tanto por Araripe quanto por Veríssimo.

Apenas, sua obra é cheia, em grande parte, não só dos defeitos inevitáveis diante dessa aberração anacrônica do que constitui o fundo de sua mentalidade, como de outros consequentes da incompletação e deficiência da sua cultura, defeitos todos estes que às vezes o arriscam até a cair no ridículo, outras vezes obscurecem completamente o que ele deseja expressar (OC, vol. I, p. 465).

Há aqui uma distância enorme em relação à interpretação geral que ele estabeleceu na monografia Cruz e Sousa, como se nesses quase vinte anos (1896-1914) a adesão ao movimento simbolista tivesse garantido um afastamento artificial ao modelo dominante de crítica e que, com o enfraquecimento da estética tanto no Brasil quanto na Europa, ele fosse "atraído" aos mesmos fundamentos e postulados dos críticos a que ele tanto se opusera no passado.

Assim, a adesão tardia ao modelo naturalista neste artigo revela, na verdade, o descolamento de forma mais profunda com a crença do futuro glorioso para a corrente "místico-simbolista" que ele apostara.

Ao tratar acerca das deficiências do artista Cruz e Sousa, além do critério racial e mesológico, apontará a filiação que o mesmo fez à "escola simbolista", também causa das incompletudes do poeta.

Seu tempo e seu meio careciam de atmosfera que lhe permitisse outra cousa. Poeta, essencialmente poeta, isto é, homem de visão e intuição por excelência, ele só poderia florescer em toda a extensão das suas possibilidades em tempo e lugar onde já se houvesse elaborado toda uma síntese a que, ainda mais, sua índole de primitivo, seu gênio apocalíptico se pudesse adaptar.

Ao contrário disso, os mais altos estímulos intelectuais que the foi dado receber vieram-lhe unicamente da escola simbolista.

Esta, em ponto pequeno, representa no seu momento um erro que faz lembrar o dos primeiros cristãos na sua crença do milenário. Mas o Simbolismo veio com ilusão oposta: em vez de acreditar que não se achava longe o fim do mundo, persuadia-se, com Maeterlinck, de que já estava próxima a era em que se iam desvendar os Mistérios da Vida, e, com Ibsen, a Conciliação entre os homens (ibidem, p. 466).

O que de mais interessante o trecho exibe é a própria desilusão de Nestor Vítor, porque, conforme ele mesmo afirma, "Cruz e Sousa não chegou a tomar-se de tal ideologia 
porque morreu quando justamente começavam a ser divulgados no Brasil os maiores representantes desse grupo" (ibidem, p. 466). Ou seja, é o nosso crítico que agora aponta a estreiteza que também representou a "escola simbolista"; é ele quem não poderia mais confiar apenas na religião da arte para "desvendar os Mistérios da Vida" e talvez, por isso, vá se voltar para o idealismo de Farias Brito, para a defesa crítica do neocatolicismo de Jackson de Figueiredo e para a ala espiritualista do modernismo nos próximos anos. É ele, finalmente, quem não enxerga a "Conciliação entre os homens", já que seu artigo escrito em junho de 1914 tem às portas o início da Primeira Guerra Mundial (deflagrada em 28 de julho).

Ao continuar a caracterização da situação do poeta, Vítor acaba por fazer um retrato do campo literário brasileiro, pouco autônomo, mostrando, por um lado, a falta de uma tradição que permitisse, por meio de uma seleção mais rigorosa dos artistas, a luta contra "um diletantismo apressado e leve" e, por outro, a falta de capital social do poeta negro, que ganhou adversários menos pelas filiações estéticas e intelectuais e mais por "motivos humanos".

\begin{abstract}
Deste modo, no meio sul-americano Cruz e Sousa representou a figura de arrojado e imponderado espectro apostólico, surgindo fora do horizonte que seria próprio, porque além de tudo lhe impôs o destino participar de uma atmosfera intelectual mofina, de uma civilização ainda bastante insipiente, nada autônoma, onde apenas é permitido, de modo normal, nas letras como nas artes, um diletantismo apressado e leve. Não pôde, sequer, afetar suficientemente com o seu vulto, na hora em que viveu, a atmosfera do país onde nascera e formara-se. Causou principalmente estranheza e despeitos, senão ódios, mas estes mais por motivos humanos, derivados de sua intransigência e de seu impiedoso sarcasmo contra outros homens de letras com quem se encontrou, do que por uma antipatia intelectual bem consciente, ainda mesmo da parte dos que representavam papel antagônico ao seu, dadas as tendências a que obedeciam (ibidem, p. 466-467, grifos meus).
\end{abstract}

Apontando traços internos à obra do poeta, Vítor defende os caracteres originais do escritor e legitima antigas críticas à sua produção poética, recolocando, a partir daí, a questão das deficiências da "escola simbolista".

O que o salvou ainda em parte na sua hora foi a sua incomparável virtuosidade para o verso, a música, a capacidade de sugestão, a intensidade e a modernidade - esta, embora, tantas vezes de mau gosto - que a obra dele oferecia. (...)

Mas os que lhe eram adversos indicaram como completas, indiscutíveis obscuridades muitas vezes os seus pensamentos mais claros, por desconexas várias das suas construções mais curiosas e até mais perfeitas, por monstruosidades, por pecados mortais contra o gosto tantas das suas concepções mais finas e mais lindas.

Ninguém pode negar, como já se disse, a boa parcela de razão que em muitos pontos tais censuras encontram, razão proveniente das causas já apontadas e mais da imitação com que ele pagou tributo ao decadismo e nefelibatismo incrustados na escola de que foi o mais alto representante no Brasil (ibidem, p. 467, grifos meus). 
Apesar de aqui o crítico reviver a ideia de "nefelibatismo" e da noção de "imitação" que foi colocada sobre nossos simbolistas, legitimando, assim, a crítica negativa do passado, ele não deixa de apontar duas qualidades que teriam sobrevivido e que ainda perpassavam o imaginário em torno da "escola simbolista": a ética que o simbolismo representou na sua luta contra as tendências dominantes do período (o materialismo e o mundanismo reinantes), e as inovações na forma, no verso, superando o enrijecimento das formas literárias manifestas pelo parnasianismo.

Tal atitude [anacronismo moral representado pela postura de "apóstolo" de Cruz e Sousa] caracteriza, tanto ou quanto, aliás, quase todos os representantes mais notáveis do simbolismo no Brasil. Em Cruz e Sousa, porém, mais do que em outro qualquer, pelo relevo que aquele temperamento selvagem lhe deu, ela começa a marcar mais nitidamente uma nova ética nas nossas letras, tirando-as do diletantismo colonial em que todos, mais ou menos, subordinados às condições do meio, até então as conservaram, e impondo-lhes, a elas, uma missão transcendental, apostólica, fazendo-as órgão, aqui, de uma reação decidida e séria contra o que tem de inferior, de bastardo, de ilusório a atmosfera criada pela civilização atual (ibidem, p. 467-8).

A “nova ética nas nossas letras", primeira qualidade levantada por Vítor, não é, como aparenta, uma visão retrospectiva sobre o movimento simbolista, como o será nas palavras de Valéry ${ }^{88}$. Trata-se, na verdade, de um prognóstico que ele desenvolverá no próximo momento em torno dos escritos e reflexões sobre o simbolismo. A ética e a moral que ele aqui defende como traços positivos da "escola simbolista" expressam realmente uma "reação decidida e séria" que será tomada como elo para o próximo momento que se materializaria no neocristianismo de Jackson de Figueiredo (um ativismo católico, de valorização da moral estrita, religiosa) e, em seguida, no espiritualismo estético difuso, manifesto em uma das alas do modernismo brasileiro.

A qualidade "ética" aqui apontada, portanto, é menos uma defesa da autonomia da arte, da literatura, frente às contingências do tempo e do "meio" e mais uma atitude normativa, política, diria, de ataque à filosofia cientificista que, querendo ou não, esteve ligada a um pensamento progressista em escritores como Sílvio Romero, Araripe Júnior ou Clóvis Beviláqua.

A "reação decidida e séria" que representou o simbolismo, na visada de Vítor, daí ele próprio se referir a ela como "anacronismo moral", ligar-se-ia, em seguida, ao pensamento

88 “(...) a Estética os dividia; a Ética os unia” (VALÉRY, 2011, p. 68). 
idealista de Farias Brito, referência a partir da Grande Guerra para os intelectuais conservadores que conformariam a chamada "reação espiritualista" 89 . A brochura Farias Brito, monografia de mais de cem páginas, publicada em 1917, iniciaria o novo momento de Nestor Vítor em relação ao movimento simbolista, afastando-o ainda mais das abordagens iniciais de seu pensamento crítico.

Quanto à segunda qualidade que destaca no trecho, aponta que a influência de Cruz e Sousa já se via nas novas gerações que adotavam, mesmo sem consciência, processos artísticos do poeta morto. Aliás, a falta de consciência e de reconhecimento, segundo Vítor, só seria superada por um outro momento em que a "complexidade intelectual" se elevasse, permitindo ampliar a influência dos processos formais instaurados por Cruz e Sousa. O interessante é que a elevação "intelectual” exigida pelo crítico só encontra paralelo, em nossa série literária, no período romântico, o que ajudará a construir, no próximo momento, uma imagem singular desta série literária: romantismo, simbolismo e espiritualismo modernista; excluindo, assim, o realismo, o naturalismo e o parnasianismo de nossa tradição.

(...) Quase toda a literatura que se pode chamar propriamente viva, no domínio da poesia, entre nós, vinda depois de Cruz e Sousa e de sua geração, consciente ou inconscientemente ressente-se mais ou menos dos seus processos. (...) Mas o seu influxo no que respeita à forma e aos estados d'alma já anda por tal modo na atmosfera de hoje, que será muito difícil a qualquer poeta de sensibilidade mais aristocrática poder de todo evitá-lo entre nós.

(...) Além disso, será preciso que esse instante ofereça considerável complexidade intelectual, caracterizada por forte surto literário e artístico, como aqui já se conheceu no período romântico (ibidem, p. 468-9).

Paralela a essas interpretações sobre o papel do simbolismo e de Cruz e Sousa, Nestor Vítor, como dito, adere tardiamente ao ideário cientificista de fundo racista e nacionalista que marcou a crítica literária oficial e que buscava apresentar uma face do país que o alinhasse a uma determinada concepção de civilização. Tal adesão de nosso crítico era, em certos aspectos, mais conservadora que a dos demais críticos da geração de 1870, como se pode verificar em outros trechos do artigo "O Poeta Negro".

Acresce que ele é um tema riquíssimo para os homens que se dedicam ao estudo da psicologia das raças. Seu caso muito interessa ao mundo a essa luz, especialmente aos homens do continente africano.

89 Já fiz alguma referência à adesão de Vítor à chamada "reação espiritualista". A historiografia literária brasileira faz menção a ela em textos como "O Simbolismo e o "renouveau catholique", seção do livro História concisa da literatura brasileira, de Alfredo Bosi, ou em "A reação espiritualista", capítulo do livro A literatura no Brasil. Era realista. Era de transição, organizado por Afrânio Coutinho. Desenvolverei o tema na seção seguinte. 
De certo ponto em diante, ele tem de figurar à parte na literatura nacional. Em tempo algum poderemos aceitá-lo como um autor nosso que corresponda no seu conjunto à capacidade estética, regular e normal, que nos é própria. Nunca assimilaremos o que ele, na sua índole ciclópica, de tipo originariamente bárbaro, oferece de vertiginoso, de disforme ao nosso gosto comedido e procedente da cultura helênica. Além disso, pela sua exígua, falseada ilustração, desvios no terreno das ideias e na composição ele comete em que seria estulto querermos incidir (ibidem, p. 468).

Os temas da "miscigenação" ou do "meio tropical", presentes em Sílvio Romero e Araripe Júnior ${ }^{90}$, passam longe da mistificação que Nestor Vítor aqui defende em torno do "poeta negro". Primeiro, isola o poeta da realidade nacional, como se fosse uma excrescência cultural e racial, que só poderia ser explicada à luz da "psicologia das raças"; segundo, nega a "ilustração" do poeta, afirmada com tanta força no estudo de 1896, para concluir que o escritor permanece "à parte" em nossa literatura porque supostamente não pertenceria ao conjunto de "nossas" características, cuja linha ascendente remontaria à "cultura helênica".

Com efeito, há aqui a adesão ao pensamento de Hippolyte Taine (1828-1893) que antes ele criticara explicitamente em textos como "Os Desplantados de Maurice Barrès" ou "H. de Balzac"91, ambos escritos em 1898. A crítica de Nestor Vítor na ocasião incidia sobre o aspecto determinista dos fatores externos que, na concepção do crítico, não atuariam plenamente sobre a formação do artista ou sobre a própria constituição do ser humano. Nesse sentido, a avaliação anterior de Vítor condenava os aspectos mais caricaturais que o determinismo naturalista impunha na crítica artística.

A crítica determinista, segundo Carmelo Bonet, alcançou o pleno desenvolvimento com Taine a partir da definição dos fatores externos mais relevantes (a tríade: "a raça, o meio, o momento") para a explicação da obra de arte (BONET, 1969, p. 77). A partir do conceito de raça, o determinismo naturalista condenaria, de fato, a criação, por exemplo, de Cruz e Sousa.

\footnotetext{
Observa nosso crítico [Taine] a tenacidade extraordinária das raças em conservar seus traços essenciais, mesmo transplantadas para climas diferentes e submetidas a culturas distintas. Nenhum caso tão ilustrativo o do povo judeu que, disseminado pelo mundo, mantém através dos séculos, só com o evitar o cruzamento com outros sangues, seus característicos físicos e espirituais.

Os atributos raciais passam à arte. Raças diferentes geram diferentes formas de arte, estilo diferente (BONET, 1969, p. 86).
}

90 Conferir os estudos já citados: O método crítico de Sílvio Romero, de Antonio Candido, O Salto por cima da própria sombra, de Luiz Roberto Cairo, e Estilo tropical, de Roberto Ventura, presentes nas referências bibliográficas.

91 Conferir "H. de Balzac", in: OC, vol. I, p. 341-50. 
O "negro sem mescla", que supostamente era Cruz e Sousa, não sofreria nenhuma influência do clima e da cultura senão aquelas das quais viriam "naturalmente" de sua "raça" e de seu "continente africano".

A educação em Nossa Senhora do Desterro (hoje Florianópolis) por meio da "adoção" que recebeu dos ex-senhores de seus pais, a aprendizagem de outras línguas, as viagens pelo Brasil, a estada no Rio de Janeiro do final do século XIX, a formação romântica, o conhecimento de autores modernos franceses como Charles Baudelaire, nada disso ${ }^{92}$ passa, nesse momento, pela análise do poeta Cruz e Sousa feita por Nestor Vítor. É o determinismo cientificista, antes criticado, que alicerça suas palavras e sua interpretação.

Tão distante é esse posicionamento, surgido às vésperas da Primeira Guerra, do que ele pregara no final do século em relação à figura ideal do "Poeta", não só em relação a Cruz e Sousa mas em relação a qualquer grande escritor. Na concepção anterior, o "Poeta" era um ser voltado não para os preconceitos do meio ou do momento histórico, mas sim para a criação artística e em relação a esta é que o "Poeta" encontrava sua tranquilidade para transmitir suas ideias. É o que ficava marcado em 1898 no estudo “Os Desplantados”.

E o Poeta não indagaria, decerto, se um jovem verdadeiramente de eleição tinha companheiros com quem comunicasse ideias. Ele saberia antecipadamente que sim, - embora que fosse no outro hemisfério, porque tinha de si para si assentado que almas destas são sociáveis por excelência, têm beijos e abraços na palavra, no simples olhar; (...) que seres assim não são homens de sociedade, são a associação sintética de todos os homens; que ele olham para o mundo como para um brinquedo de criança, rindo-se um pouco, mesmo dos próprios Taines (...) (OC, vol. I, p. 67-8).

A distância que parece tão grande nessa comparação talvez se afigure um pouco menor se tivermos em mente que, mesmo nos escritos de Nestor Vítor entre 1896 e 1902, havia um núcleo do pensamento cientificista, ainda que sem o determinismo apregoado pela crítica oficial.

Nos seus estudos iniciais, a ideia de raça nunca foi completamente rejeitada, o que ocorreu é que ela foi matizada por meio da noção do "gênio" artístico, a qual, além de ser "romântica", também era uma noção da crítica cientificista, ao menos em Ferdinand Brunetière $^{93}$, de modo que ele manteve intacto esse núcleo do modelo naturalista de crítica.

92 Para informações biográficas acerca de Cruz e Sousa, conferir Poesia e Vida de Cruz e Sousa, de Raimundo Magalhães Júnior.

93 Segundo Carmelo Bonet, Brunetière defendia a noção de "gênio" a partir da perspectiva evolucionista para tratar da transformação dos gêneros literários: "Brunetière traz uma nova, muito importante, decorrência do darwinismo: a individualidade, ou seja, 'o conjunto de qualidades ou de defeitos que fazem com que um indivíduo seja único em seu gênero. Acrescenta que este ser excepcional introduz na história da literatura e da arte algo que antes não existia, e que não houvera existido sem ele, e que continuará existindo depois 
O que não é de se espantar também, tendo em vista, como já afirmei, tratar-se do modelo dominante de pensamento nas últimas décadas do século XIX, tendo participado da formação intelectual de nosso crítico e chegando às primeiras décadas do século $\mathrm{XX}$. Escrevendo em 1965, René Wellek apontava que, somente após a Segunda Guerra Mundial, a crítica determinista e a tríade taineana foi, de fato, abandonada.

\begin{abstract}
A fórmula 'raça-meio-momento tem sido severamente criticada. 'Raça', principalmente por ter sido usada e abusada pelos nazistas, parece um conceito desacreditado hoje em dia - ao menos no que concerne à literatura. (...) Não podemos acreditar numa 'raça' francesa, inglesa ou alemã; muito menos na estabilidade e na completa distinção de respectivas características psíquicas e, portanto, de tradições literárias (WELLEK, 1972, p. 26).
\end{abstract}

Embora, para Wellek, a apreensão do conceito de "raça" nunca tenha respeitado a própria obra de Taine, para o qual "raça (...) é simplesmente o espírito francês ou o caráter inglês" e que "não explica um indivíduo" (WELLEK, 1972, p. 28), parece-me que foi essa visão mecânica, simplista, que começamos a ver estampado aqui na avaliação de Nestor Vítor: a separação de Cruz e Sousa da cultura (e literatura) brasileira em função de ser "negro sem mesclas", um "gênio primitivo", portanto.

Não obstante, a separação nunca será definitiva. Sempre houve para o poeta Cruz e Sousa um lugar de exceção: antes, de "gênio" de requintada "civilização"; e, agora, de "primitivo genial”, o que revela que sempre houve também o diálogo de Nestor Vítor com a crítica literária oficial do período. Uma crítica cujo espaço era dominado pelo cientificismo naturalista e, por isso, fornecia os referenciais para o espaço crítico, dos principais e dos secundários.

Dito isso, torna-se mais explicável a aparente contradição que apontamos no segundo capítulo em torno da inclinação e da homenagem de Nestor Vítor em relação a Sílvio Romero.

O autor de Evolução do lirismo brasileiro (1905) apontou parcialmente as diretrizes para o pensamento de Vítor, como ele próprio, Sílvio Romero, assimilou em parte as ideias de Nestor Vítor sobre o simbolismo e a arte de Cruz e Sousa. O capítulo XVII de Evolução do lirismo brasileiro, escrito originalmente em 1899 para figurar no Livro do Centenário, é o estudo mais elogioso feito ao simbolismo e ao poeta negro por um crítico naturalista. Sem dúvida, para além da polêmica levantada em 1927 por Alberto de Oliveira, comentada no

dele. (...) Em literatura, a ação do gênio confirma a tese de Brunetière. O gênio desempenha na evolução literária o papel do ‘acidente feliz’ na evolução das espécies” (BONET, 1969, p. 102-103). 
capítulo anterior, Sílvio Romero recebeu a influência de Nestor Vítor. É o próprio crítico consagrado que assegura:

É o último poeta que temos de rapidamente notar; porém dá prazer ao critico avistarse com um homem destes, um íntegro, um nobre espírito de eleição. Deixou publicados, em poesia, os Broqueis e inéditos — Faróis e Últimos Sonetos. Devemos à delicadeza do sr. Nestor Vítor, grande amigo do poeta e que se encarregou de publicar-lhe as obras póstumas, a ventura de ler os manuscritos do ilustre morto, que nos é hoje plenamente conhecido ${ }^{94}$ (ROMERO, 1905, p. 194-5).

Seria, talvez, interessante cotejar o texto de Romero com as formulações anteriores de Vítor para mostrar o intercâmbio de análises sobre o poeta morto. Ressalta-se, por exemplo, os elogiosos comentários em torno da "dignidade de caráter" ou de "elevação de alma" que Cruz e Sousa traria em sua poesia; comentários que figuram tanto no texto de Romero quanto nos escritos de Vítor. Importa, no entanto, menos o reconhecimento da influência mútua, esse espaço comum da crítica em que os principais e os "secundários" encontram-se, e mais, para o presente estudo, o fato de que o critério de diferenciação nacional que foi central no crítico sergipano reapareça na crítica de Nestor Vítor por meio da adoção do critério étnico (como aquilo que é "nosso", aquilo que é nosso "legítimo lirismo") e por meio da mesma aferição da qualidade das obras, ligada à “diferenciação" com outros movimentos ${ }^{95}$.

De fato, vemos convergir o julgamento tanto de um quanto de outro no que tange à "superioridade" dos livros de Cruz e Sousa: Faróis e Últimos Sonetos seriam superiores às obras anteriores por melhor expressar a "lírica nacional" (nas palavras de Sílvio Romero, em 1905) ou por se adequar melhor a "moldura nacional"" (nas de Nestor Vítor, em 1914). E, na interpretação de ambos, ainda que em momentos distintos, o simbolismo teria representado uma "reação espiritualista". Assim, Vítor parece seguir a trilha deixada por Romero.

Para findar: o simbolismo, nome por certo mal escolhido para significar a reação espiritualista que neste final do século se fez na arte contra as grosserias do naturalismo e contra o diletantismo epicurista da arte pela arte do parnasianismo, é, nas suas melhores manifestações líricas, uma volta, consciente ou não, ao romantismo naquilo que ele tinha também de melhor e mais significativo (ROMERO, 1905, p. 200).

94 Também procedi à atualização ortográfica neste e no próximo extrato do livro de 1905 de Sílvio Romero, de modo a facilitar a leitura.

95 Nesse sentido, a diferença que a poesia simbolista de Cruz e Sousa representou na evolução de nossa literatura em relação à já "passada" literatura parnasiana.

96 Avaliarei a posição de Nestor Vítor e a defesa que faz de Últimos Sonetos como o melhor da produção do poeta ao tratar do estudo "Cruz e Sousa", publicado em 1923, em função dos 25 anos da morte do escritor e da publicação da primeira edição de suas Obras completas. 
Estas palavras de Romero abrem uma caminho que Nestor Vítor só trilhará completamente no próximo e último momento de sua crítica em torno do simbolismo que vai de 1917 até 1930. Vemos, assim, como começam a se entrelaçar nitidamente simbolismo, romantismo, espiritualismo e nacionalismo em uma unidade e identificação que não seria de imediato reconhecível se não se observasse os diferentes momentos do pensamento crítico de sua obra.

\subsection{A arte ultrapassada pela moral}

Antes de adentrar na análise de alguns dos textos produzidos no último momento de apreensão do simbolismo por Nestor Vítor, farei uma discussão acerca da questão moral que aparece tão fortemente nessa fase da produção de nosso crítico, de modo a evidenciar em que sentido essa questão foi ou não uma preocupação consciente de Vítor e em que sentido ela interferiu em suas formulações em torno da arte simbolista e de sua autonomia diante das determinações políticas e sociais do período.

Gisèle Sapiro em La responsabilité de l'ecrivain busca traçar, em relação à sociedade francesa, os momentos constitutivos da noção de responsabilidade do escritor frente ao seu discurso, fazendo coincidir a avaliação dessa noção ("responsabilidade") com a emergência do próprio escritor moderno.

Nesse sentido, ela acolhe em sua análise os períodos em que os diferentes campos (o jurídico, o religioso, o político e o artístico) se entrelaçaram e se diferenciaram. Particularmente, avalia quatro épocas da história francesa a partir do século XIX: a Restauração (1814-1830), o Segundo Império (1852-1870), a Terceira República (1870-1940) e a Liberação/Libertação ("Liberation", a partir de 1940). Empreendimento que lhe permite avaliar como as questões do direito e da moral conformaram a própria instituição da literatura como um campo mais ou menos autônomo.

Utilizarei, nesta seção e na próxima, algumas de suas contribuições para analisar o papel da moral no percurso de Nestor Vítor no que se refere à avaliação que realiza em torno do movimento simbolista.

Vimos já, por exemplo, no presente capítulo, que o primeiro momento de apreensão do simbolismo por nosso crítico parece coincidir com a defesa de maior autonomia da arte e da literatura e de defesa do julgamento estético como superior aos julgamentos morais, políticos 
ou "sociológicos", contrapondo-se, assim, às posturas que conformariam o principal da crítica literária nacional.

Nesse sentido, o movimento crítico intentado por Vítor em fins do século XIX encontraria seu paralelo no processo que se iniciara na França ainda no começo dos oitocentos. Segundo Gisèle Sapiro, a filosofia kantiana que defendia a separação entre o belo e o bom, entre o belo e o útil, seria atualizado por Madame de Staël:

Dans De l'Allemagne, celle-ci énonce ce qui va devenir la règle de l'autonomie de l'oeuvre par rapport à la morale, en conférant à la distinction kantienne du beau et de l'utile le sens que lui donnent les romantiques d'Iéna réunis autour de Friedrich et August Wilhelm Schlegel (SAPIRO, 2011, p. 168).

Ainda que essas ideias no período da Restauração não encontrassem terreno fértil, uma vez que a França era "un pays où prédomine la conception de la mission morale et sociale de l'art" (ibidem, p. 169), elas puderam se difundir e tornar fonte para muitos artistas, chegando em meados do século a um escritor como Gustave Flaubert que "trouvera ainsi matière à étayer sa conception de l'art pur - une conception qui lui vient des romantiques" (ibidem, p. 169).

No caso do Brasil, Nestor Vítor assumia o discurso do divórcio necessário entre o julgamento estético e o julgamento moral/social em razão do contexto de recepção das obras simbolistas. Como já afirmei, era uma exigência objetiva que se colocava aos escritores alinhados à estética decadista/simbolista para que pudessem ingressar no restrito mercado das letras nacionais. O discurso da separação, do divórcio das áreas aparecia objetivamente para se contrapor a uma concepção moral e social da arte, endossada por críticos do porte de Sílvio Romero ou Araripe Júnior.

A defesa de uma maior separação dos conhecimentos e das posturas práticas não era, no entanto, nova, podemos encontrar reflexos dela em dois textos de Machado de Assis (1994), "O Ideal do Crítico" e o "Notícia da atual literatura brasileira: Instinto de nacionalidade", de 1865 e 1873, respectivamente, que apoiavam, primeiro, certa imparcialidade do crítico na aferição das obras, rejeitando os preconceitos de "escola" e, segundo, a adoção de uma maior abertura para referenciais universais da literatura, de maneira que "o nacionalismo em arte" se expressasse mais pela disposição de espírito do escritor do que pela adoção de marcas exteriores que servissem para pintar "a cor local"97.

97 Conferir os dois textos de Machado de Assis em suas Obras Completas (1994). 
A própria perspectiva do isolamento do artista, do gênio, por mim já evocada nos primeiros textos críticos de Nestor Vítor respondia à teoria da função da arte levantada pelos críticos naturalistas.

Os simbolistas, em seu isolamento imposto por contingências exteriores, precisavam fazer o elogio do próprio isolamento contra a teoria do artista que representa a coletividade. Em favor do polo subjetivo, era preciso menosprezar o polo objetivo expressamente defendido pela crítica oficial. Vejamos, por exemplo, um trecho do texto de Araripe Júnior “A arte como função", de 1887:

\begin{abstract}
Os produtos da arte, embora imediatamente subordinados ao subjetivismo do artista, do mesmo modo que a linguagem do direito, a política e a religião, não podem aparecer senão como produto social; nem há, mesmo, quem a conceba fora das relações de coletividade. Sem a repercussão do meio, toda a arte seria nula e inviável; é este que a completa, se é que não a provoca. A observação de todos os dias nos mostra que, sem público, não há literatura, como, sem exercício, não há função e, sem a necessidade de função, não há órgão. (...) Ridículo, portanto, é dizer-se que o gênio, por isso mesmo que o é, pode viver na contemplação de si próprio, desligado do ambiente, entregue ao solitário pensamento que só um futuro ultraterrestre compreenderá, mergulhado no nirvana búdico de uma poesia extrahumana. Não creio na existência de seres que vivam assim ao lado da história, completamente fora do movimento solidário da humanidade, nem tampouco nesses privilegiados de que fala Schopenhauer, cujo centro de gravidade cai dentro de si mesmos (ARARIPE JR., 1958, p. 509-10).
\end{abstract}

Com efeito, poder-se-ia dizer que toda a produção inicial de Vítor buscou responder a esse tipo de formulação da crítica oficial naturalista. A questão da "moral" que figurava, por exemplo, no estudo Cruz e Sousa, escrito em 1896, era, na verdade, a assunção da "Arte" como essencialmente livre das contingências exteriores.

\begin{abstract}
A Arte eterna, a simples Arte, é una e indivisível, embora em cada artista se manifeste por uma nova nota, em cada época por diversa expressão. Ela, apesar disso, resiste e resistirá em todos os tempos, impoluta e íntegra, sem que os Bárbaros consigam profaná-la ou fazer de seus destroços retalhos para flâmulas de sangue (OC, vol. I, p. 14).
\end{abstract}

A defesa idealista da arte conformava uma espécie de "ética", no sentido que lhe atribuiu Paul Valéry (2011) ou como explica Gisèle Sapiro:

Contre la logique économique de rentabilité à court terme (les chiffres de vente), qui régit de plus en plus le pôle de grande production du champ, se forme, vers le milieu du XIX siècle, un pôle de production restreinte, qui décrète l'irréductibilité de la valeur esthétique à la valeur marchande du produit et la prééminence du jugement des spécialistes (les pairs et les critiques) sur les sanctions d'un public de profanes, selon l'analyse qu'en a propose Pierre Bourdieu. L'esthétique devient une éthique professionnelle (SAPIRO, 2011, p. 30). 
A estética aparece na primeira fase de Nestor Vítor como uma ética profissional, figurada sobre a forma da "independência" ou da "seriedade espiritual" ou do "ascetismo intelectual". Ao diferenciar os simbolistas dos românticos e dos naturalistas, Nestor Vítor assim se pronunciava em 1896 :

\begin{abstract}
O núcleo que ora se prepara para tomar conta do terreno, na Arte, desdenha de Epicuro e não anda com nostalgias de banais e culposas Boêmias. Somos homens, nós os que vimos com a fé dos que se julgam chamados, homens que procuram viver em integridade afetiva e moral, por entendê-las completativas e dignificantes.

É claro que a hora certa, que é o hábito no sentido pacato, e os olhos baixos para não ver, que é a convenção, não nos irão emparelhar à vulgaridade boçal ou aos Tartufos da beatice fingida no mundo burguês. A nossa independência é apenas subordinada à alta seriedade espiritual (OC, vol. I, p. 29).
\end{abstract}

Enquanto nas décadas de 1880 e 1890, o literato era compelido pela crítica naturalista a participar da vida social, instado a participar do nacionalismo literário, a "independência" dos simbolistas, ao menos em tese, no discurso, subordina-se apenas ao credo da arte.

Em “Os Desplantados”, escrito em 1898, a defesa de uma "moral” é novamente a crítica à subordinação da literatura ao patriotismo. É novamente a defesa de uma "seriedade espiritual" que combata pela autonomia da arte, e que se apoie no julgamento estético distante do julgamento moral e/ou político.

As páginas extraordinárias d'Os Desplantados quais são? São todas aquelas em que ele fala como panteísta naturalista, das coisas. As inferiores são todas as outras com preocupação de pátria propriamente. É que as primeiras lhe nascem da alma, são o produto de sua cultura, o fruto de suas crenças, a sua sincera e leal expressão: as outras vêm da necessidade de propaganda, resultam de transações no íntimo do espírito, reveladoras de incompletação de desenvolvimento em sua individualidade moral (ibidem, p. 71).

Aqui, Nestor Vítor coloca-se contra “o princípio da utilidade social da arte" de que fala Sapiro ao sustentar que, no século XIX, tanto o romantismo quanto o realismo opuseramse a este princípio: “Le romantisme en posant les prémices de la théorie de l'art pour l'art qui dissocie le 'beau' de l' 'utile', le realisme en dissociant le 'vrai' du 'beau idéal'. Mais tous deux proposaient une morale alternative, individualiste pour le premier, collectiviste pour le second" (SAPIRO, 2011, p. 297). Barrès não teria sido fiel à moral da arte (mesmo ao "panteísmo naturalista") para se ater a uma moral exterior, a da "pátria", no que fazia surgir as "páginas inferiores”, a má literatura que Vítor critica. 
Entretanto, essa postura inicial em que predomina a defesa da autonomia, do julgamento estético e contra princípios exteriores à própria ética da arte é, a partir da ida a Paris, paulatinamente enfraquecida, dando lugar a julgamentos morais em que o papel "natural" da mulher", a defesa da "pureza" da criança99, e, sobretudo, os valores espirituais religiosos (cristãos) sobrepõem-se na avaliação literária das obras.

Um exemplo desse novo momento é a análise que realiza do livro de João do Rio (Paulo Barreto), As religiões do Rio, em 1906. Em determinado ponto do artigo, Vítor afirma que o salva João do Rio de ser um mundano, um "amoral", é o de expressar em seu livro a repulsa pelas religiões afrodescendentes e pelos positivistas não cristãos, como Teixeira Mendes.

\begin{abstract}
Quem olhar bem atentamente para estas páginas das Religiões no Rio observará: no fundo daquele espírito, que a todo transe se quer fazer absolutamente mundano, despreocupado, amoral, e até mesmo um tanto ou quanto irreverente, há os disjecti membra de um homem de princípios e até, de modo mais vago ainda, os de um indivíduo capaz de ter uma crença. João do Rio não pôde conter de todo a sua repulsa quando nos fala das práticas nauseantes e grotescas da feitiçaria africana e da exploração sem vergonha, muitas vezes criminosa, dos espíritos falsificados. Também é fácil observar o secreto constrangimento com que ironiza os positivistas, para não abrir exceção de mau gosto, e, principalmente, o seu respeito íntimo pelo venerável Sr. Teixeira Mendes, a quem nem sequer tem a simples audácia de solicitar um interview direto (OC, vol. I, p. 385).
\end{abstract}

Entretanto, a caracterização que fiz sobre o período de 1906 a 1914 como um momento intermediário, de transição, em relação a um modo de apreender o simbolismo e a arte, deve-se ao fato que, nessa fase, ao lado de colocações como esta acima, havia outras em que a defesa da autonomia, da separação dos julgamentos ainda se apresentava constantemente. Talvez porque, para além do sentido teórico, abstrato, que a defesa da arte assumiu na sua primeira fase, sempre houve um outro uso, talvez indissociável deste, que permaneceu nesses anos de transição, que é o uso instrumental de autonomia da literatura, do uso instrumental da primazia do julgamento estético.

98 Por exemplo, na crítica que faz ao livro de Laura Fonseca e Silva, Serenidade, no qual subordinava o "senso estético" à avaliação do que era mais natural ao sexo feminino, ainda que afirmasse que o crítico literário não deveria ter "pretensões ortopédicas na formação da alma dos autores". (Conferir OC, vol. II, p. 132.). Ou na avaliação que faz do livro de Auta de Sousa, expressão natural também da "alma" feminina.

99 Em artigo de 1902, já em Paris, ao comentar a morte de Émile Zola, Vítor reafirma a liberdade da arte: "(...) as obras de grande arte em todos os séculos sempre foram as filhas da liberdade", mas prescreve também que as grandes obras, como as de Dante, Cervantes ou Homero não podem chegar às crianças: "Não se deve pôr às mãos de uma criança de nove anos, que é tão belo ser ainda arcangélica, nenhuma dessas obras formidáveis" (OC, vol. III, p. 92-3). 
Assim, diante dos adversários de campo, a especificidade da literatura era utilizada como arma, lembrando aos acadêmicos, por exemplo, a necessária separação entre os assuntos políticos e sociais e as demandas próprias da instituição literária. Como exemplo, posso citar o artigo "A Academia Anarquizada" de 1912 em que o crítico defende o critério da especificidade literária contra o mundanismo e a política da Academia Brasileira.

\begin{abstract}
Basta a exposição desses fatos [indicação de Oswaldo Cruz e Lauro Müller], dois já produzidos, e outro em risco de produzir-se, para demonstrar a toda prova que a Academia Brasileira de Letras está seguindo péssima orientação querendo ainda deste ponto de vista macaquear a Academia Francesa. É evidente que só se desmoraliza e portanto tende a dissolver-se uma corporação literária cujos novos membros nem sequer têm a capacidade de fazer um elogio decente daqueles a quem vêm suceder. É o mesmo que admitirem-se numa sociedade científica novos colegas que sejam incapazes de formar justa ideia da obra e do valor de outros a quem substituem, e isso por incultura patente, ao menos no que respeita à ciência. Por essa forma tais agremiações tornam-se irrisórias, fazem-se carnavalescas. Elas são próprias dos países de opereta, das terras que representam a paródia da civilização (OC, vol. I, p. 443-4).
\end{abstract}

Do mesmo modo, ainda em 1914, em “O Poeta Negro", último texto analisado na seção anterior deste capítulo, o elogio do apostolado da arte comparece para reafirmar o antigo princípio da defesa da "seriedade espiritual", o que demostrava que o crítico ainda mantinha vivo o exemplo da postura ética do escritor que subordinava a sua vida à arte ao invés do contrário: "Mais ainda, o seu exemplo moral não foi perdido e continuará a influir no que tenha, com efeito, de humano e pertinente dentro das funções que cabem a um intelectual" (ibidem, p. 468).

Diria, inclusive, que a percepção da independência do artista, de autonomia da arte, de sobrevalorização do julgamento estético manteve-se como parte do discurso de Nestor Vítor, embora não de forma dominante, em toda a sua atividade crítica. Porque o princípio do estético, sobretudo, esteve subordinado à dinâmica do campo literário ainda pouco autônomo. Por essa perspectiva, é possível encontrar no final de sua carreira em 1927, por exemplo, a crítica aos "intuitos moralizadores" na arte, revelando uma postura de defesa de autonomia. No entanto, tal crítica é amalgamada a uma visão prescritiva sobre o que seria a melhor arte, o que, em última instância, acaba sendo também uma prescrição moral porque condena de antemão o velho naturalismo, cujos princípios, segundo o crítico, trazem um "íntimo desmoronar" de valores.

A arte nunca foi, nunca será inócuo passatempo. Ela ou faz bem ou faz mal. Pode prejudicar até com intuitos moralizadores, mas imbecis, porque não está nela 
moralizar propriamente. O próprio da arte é proporcionar encanto. Este, contudo, maleficiará, seguramente, sempre no artista haja o íntimo desmoronar próprio dos princípios de que resultou o naturalismo. Assim também será edificante quando quem escreva tenha nascido para escrever e valha a pena a outros homens conviverem com seu espírito no que ele possa dar de mais fiel a si mesmo, pelas bases em que se apoia (OC, vol. II, p. 387).

Com efeito, o trecho acima é parte de artigo que Nestor Vítor escreveu quando do lançamento da Revista Festa, liderada por Tasso da Silveira. O artigo objetivava apontar a seriedade da empreitada e traçar um panorama da literatura até o presente quando as vanguardas já eram bem conhecidas em São Paulo e no Rio de Janeiro e o crítico visualizava um novo momento para as letras nacionais. Ou seja, no momento de um novo "novo", Vítor reacende o ideário da separação da arte em relação à moral (defende-o), mas, como no final do século XIX, o faz em um quadro em que revive também as antigas disputas no interior do campo literário brasileiro, buscando rejeitar qualquer resquício naturalista que, por acaso, sobreviva nos escritores da revista Festa.

A questão moral, no entanto, de coadjuvante passa a primeira plano em alguns de seus textos principais do próximo momento de apreensão do simbolismo, em uma fase que o movimento já foi decretado como encerrado e é preciso fazer o seu balanço e mostrar a sua herança e as suas lições. E ele inicia isso no interior da Primeira Guerra Mundial, em 1917.

Como no caso da França, analisado por Gisèle Sapiro, a Grande Guerra parece colocar a defesa da autonomia da arte em xeque, nascendo o que ela chama de um "moralismo nacional" que condenará, particularmente, a herança romântica "accusé d'avoir perverti le 'génie français' qui serait d'essence classique" (SAPIRO, 2011, p. 512). Como o "gênio brasileiro" parece encontrar-se justamente na herança do romantismo literário, considerado pelo grosso da historiografia de então como o início de nossas letras, de nossa independência cultural, Nestor Vítor, como outros intelectuais do período, volta-se para o nosso romantismo e, a partir dele, lança a sua própria versão de "moralismo nacional".

A “versão" de Vítor, como a francesa ${ }^{100}$, também encontrará um meio para se desenvolver e se confrontará com as novas experiências que aqui estão surgindo, seja a diluição das "antigas escolas" de que também resulta parcialmente a ala espiritualista de nosso modernismo, seja o surgimento dos "futuristas", tendo à frente os "andradistas", influenciados pelas vanguardas europeias.

$100 \mathrm{Na}$ França, a investida contra a autonomia relativa do campo será contraposta por duas respostas: “l’une provient du pôle esthète du champ littéraire, que va incarner après la guerre La Nouvelle Revue française, l'autre de l'avant-garde surréaliste" (SAPIRO, 2011, p. 513). 
Sobre a recepção dos "modernismos" na obra de nosso crítico, tratarei no próximo capítulo. Por agora, essa discussão preliminar sobre a relação entre arte e a moral serve como preâmbulo para o grosso da análise do próximo e último momento de apreensão do simbolismo nos escritos críticos de Nestor Vítor, uma vez que, em minha interpretação, o movimento e seus representantes vão ser lidos menos pelo viés estético e mais pelo viés moral, nacionalista, o que, sem dúvida, esteve ligado ao "cataclismo" que representou a Grande Guerra.

\subsubsection{O simbolismo lido como "reação espiritualista"}

(...) Não há dúvida que o Simbolismo já não conta entre nós, e creio que não conta mais em parte alguma do mundo, com filiados ortodoxos, a não ser que se trate de escritores incipientes ainda, capazes de acreditarem que estão criando coisa nova, quando apenas reproduzem, mais ou menos, os chavões daquela escola fugaz. Mas a tendência romântica, que o Simbolismo despertou, persiste, e persiste ao lado dessa tendência a inclinação para o espiritualismo, talvez ainda em mais alto grau do que há vinte anos atrás, embora sob diferentes disfarces (Farias Brito, OC, vol. I, p. 245).

O livro Farias Brito, publicado no Rio de Janeiro em 1917 com 101 páginas $^{101}$, é, sem dúvida, o mais longo texto crítico de Nestor Vítor nessa fase. É também, sem dúvida, um estudo que consegue reunir claramente aqueles quatro termos que já estiveram separados ou opostos no início da produção do escritor: simbolismo, romantismo, nacionalismo e espiritualismo.

O primeiro comentário que poderia ser destacado aqui é o fato de Nestor Vítor ter dispendido energia intelectual para ler e avaliar a obra de um escritor que dedicara a sua vida a debater assuntos filosóficos e não propriamente literários ou artísticos, que concentrara sua produção nas questões da filosofia e não especificamente nas da arte e de seus desdobramentos na sociedade ${ }^{102}$.

A empreitada de Vítor em torno da obra do pensador pode ser explicada por alguns elementos conhecidos. Primeiro, o contato inicial ocorre por meio do amigo e conterrâneo Rocha Pombo (1857-1933) que apresenta a obra Finalidade do Mundo do pensador cearense,

101 Conforme indicação da Obra Crítica: "Livro de 101 páginas. Na folha de rosto lê-se: 'Nestor Vítor / Farias Brito / 1917 / Revista dos Tribunais - Júlio César, 55 / Rio de Janeiro.’” (OC, vol. I, p. 190).

$102 \mathrm{Na}$ juventude, como outros bacharéis do período, Farias Brito escreve um volume de poesia, Cantos Modernos, publicado em 1889, mas, a partir da década de 1890 até sua morte em janeiro de 1917, dedica-se sobretudo à filosofia, publicando vários volumes que se reuniram sob dois títulos, "A finalidade do mundo" e "Ensaios sobre a Filosofia do Espírito". Conferir informações biobibliográficas nos estudos introdutórios ao livro de Farias Brito $A$ verdade como regras das ações, publicado pelo Senado Federal em 2005. 
revelando ainda no primeiro decênio do século XX que havia um corajoso a "falar de novo em filosofia espiritualista" (OC, vol. I, p. 191). Segundo, em 1909, Farias Brito realiza concurso para o Colégio Pedro II e, depois da morte de Euclides da Cunha, assume a disciplina de Lógica. Nestor Vítor, em 1906, havia retomado o magistério no externato do Colégio Pedro II. Terceiro, a amizade que se estabelece a partir dos anos de 1910 com o pensador $^{103}$. Quarto, a morte do escritor no início de 1917 (janeiro) que permite a Vítor uma avaliação completa de sua obra, vindo a publicar o seu estudo no final do mesmo ano.

Aliado a esses fatores conhecidos, deveria contar o clima de surgimento de um nacionalismo mais ativo, mais social e menos individual, que exigiria dos homens de letras do período uma posição "moral” mais ativa. A leitura de Farias Brito, segundo Prado (1983), ocorreria nesse período dentro de um clima de patriotismo ufanista e ativo.

Nos anos de 1910 aparecem algumas obras que denunciam o nacionalismo individualista, "produto de afetividade", que se manifestava, por exemplo, no início da produção de Elísio de Carvalho e em sua busca "retrospectiva de nossas pretensas raízes épicas" (PRADO, 1983, p. 22) e que se colocam, assim, por uma nacionalismo ativo e moralizador. São exemplos das obras citadas por Prado os livros O Brasil na Primeira Década do Século XX, de Sílvio Romero, publicado em 1912, As fontes de vida no Brasil, de 1915, de Alberto Torres, e A Literatura Nacionalista, de Andrade Muricy, de 1916. Sem dúvida, livros que Nestor Vítor pôde ler antes de $1917^{104}$ e que definiriam um "nacionalismo dirigido pela razão" (ibidem, p. 24) e que, no fundo de suas críticas ao atraso do país, apontavam a necessidade de um nacionalismo mais ativo e também autoritário, porque elevavam o "Estado como órgão da vida social da Nação" (ibidem, p. 24).

Desse modo, é, no interior desse nacionalismo (que se delineia em meados de 1910), que o surgimento da Primeira Guerra acaba impulsionando ainda mais uma nova mentalidade entre os homens de letras que instrumentalizará o pensamento de Farias Brito, permitindo assim também o contexto de produção para a leitura que Nestor Vítor realiza.

Lembremos, ainda, que desse radicalismo revanchista sairão moções de aplauso ao Governo republicano pela decisão de aceitar o repto da Alemanha e entrar para a

103 Comentando as amizades de Farias Brito, Antônio Carlos Klein afirma: "Os encontros de Jackson com Farias Brito levam-no a partilhar da intimidade da casa do filósofo, onde ficavam, na varanda, conversando até tarde a sós ou na companhia de outros intelectuais arregimentados para as tertúlias, sobretudo Rocha Pombo e Nestor Vítor" ("Farias Brito: Uma vida extremamente rica", in: A verdade como regras das ações, 2005, p. LXI).

104 No próprio estudo Farias Brito, Vítor comentou a obra de Alberto Torres; ver OC, vol. I, p. 245-6. Antes, em novembro de 1916, Vítor escreveu uma carta a Muricy, comentando a leitura deste livro citado por Prado; conferir OC, vol. II, p. 80-1. 
Guerra deflagrada em 1914. O exemplo parece ter repercutido nas aspirações hegemônicas dos grupos que sustentavam a necessidade de definir o Estado nacional: fala-se agora em 'sustentar a todo transe a ordem constitucional', em fazer a propaganda do Brasil dentro do Brasil, em estreitar a federação política e espiritual, divulgando estrategicamente a 'obra humanista' de Farias Brito. A Guerra, nesse contexto, ao mesmo tempo em que surge como um castigo da Providência à fome comercial e às imposições materialistas dos países detentores do mercado internacional, é recebida como 'a mais gloriosa condição de paz e de amor no seio da humanidade' já que traria em seu bojo não apenas o fim da ciência haeckeliana e de sua 'civilização apodrecida', mas particularmente uma etapa posterior de renascença espiritual, de ordem e de disciplina (PRADO, 1983, p. 25).

De fato, a aproximação que Nestor Vítor fará com a obra de Farias Brito indica dois movimentos: a repetição agora atualizada da crítica ao materialismo cientificista e seus desdobramentos na arte e na literatura e a defesa de um nacionalismo supostamente mais autêntico, mais verdadeiro, mais condizente com o "espírito nacional" e com o "nosso povo".

Afirma logo nas primeiras páginas de seu estudo que Farias Brito era um legítimo representante do povo:

Era ele, conseguintemente, de certo ponto em diante, um grande solitário neste mundo, do qual se considerava destinado a partir com as mãos relativamente vazias, falando-se do que respeita ao afeto amical, embora representasse, dentro todos os brasileiros, a alma que, no terreno das ideias, já traduziu quanto em nós haja de mais profundamente piedoso para com os homens e para com a Natureza. Sua obra filosófica, em linha geral, é a expressão das nossas mais profundas tendências intelectuais, morais e éticas (OC, vol. I, p. 193).

O "isolamento" do pensador afigura-se muito próximo ao isolamento dos artistas "místicos" outrora defendidos por Vítor. Sabemos que tal isolamento nascia de causas sociais, embora no discurso de nosso crítico, muitas vezes, era visto como um atributo em si dos artistas, dos "gênios". O fato era que o pensador estudado por Vítor teve que marchar contra a corrente: "pronuncia-se Farias assim contra toda essa tendência ativista que avassalou vitoriosamente o mundo pode-se dizer que de há cinquenta anos para cá” (ibidem, p. 223). Ou seja, Nestor Vítor se refere à geração de 1870, encarnada em toda uma geração de intelectuais, particularmente, nos homens de letras e nos críticos literários, seus adversários.

A resistência de Farias Brito produziu então a correspondência mais "profunda" com o "verdadeiro Brasil", permitindo que ele fosse lido como o maior representante de nossa "índole".

O verdadeiro Brasil, aquele não é influenciado por modas de que nos tragam notícias os transatlânticos todas as semanas, é católico, embora a seu modo, e como tal inativista, até a medula. Nisto nós somos, como coletividade, justamente o oposto do 
que representa o yankee. Podemos dizer: somos o outro polo da América, polo que nela estabelece por tal forma o ritmo indispensável na sua evolução. Inativistas quer dizer aqui inimigos radicais daquele progresso febril e sem finalidade cujo amor abrasa os filhos da outra metade do continente. Nós somos como povo, pelo contrário, amigos do que está, estacionários, digamos, por uma volúpia, por um amor ao descanso, à contemplatividade que quase confina com o sentimento budista e que o nosso filósofo atinge na sua concepção finalística. Somos crentes e simples, desambiciosos e sensatos. É o resultado do que herdamos da península, do selvagem e do negro. Tudo o mais é superfetação, é excrescência, é verniz muito por cima, aqui.

Farias Brito ainda vai mais longe na aproximação que instintivamente procura com a índole filosófica e religiosa do nosso povo (ibidem, p. 224).

Aqui verifica-se com clareza a oposição entre o pensamento de Nestor Vítor desta última fase e o de sua primeira fase: forja-se um discurso em torno do que é "natural" à cultura brasileira. A partir daí, estabelece-se uma linha de divisão com o estrangeiro, com o exterior, com o artificial. A defesa do cosmopolitismo que aparecia no livro A Hora, a defesa da superexcitação dos sentidos e de sua artificialidade nos estudos sobre Cruz e Sousa ou sobre Maurice Maeterlinck desaparecem no estudo sobre Farias Brito. Torna-se mais claro também o conteúdo da pequena polêmica que Vítor desenvolveu em 1919 com Ronald de Carvalho, citada no segundo capítulo, em que o nosso crítico apontava o caráter "alienígena" da poesia de Ronald. Os critérios de avaliação de Nestor Vítor haviam se modificado e ele havia aderido com mais força ao nacionalismo literário, ainda que sob a roupagem da reação espiritualista, materializada aqui a partir da leitura de Farias Brito.

Entretanto, a oposição entre as "fases" e a suposta "coerência" dos novos critérios de avaliação não devem servir apenas a uma leitura da trajetória do "pensamento" de nosso crítico, porque a objetivação desse pensamento a partir de seus textos críticos funcionava em contextos específicos, não podendo ser tomada abstratamente.

De fato, a identificação entre a filosofia "espiritualista" e a alma do "povo" serve, nessa nova fase, a objetivos bastante precisos: resgatar a literatura subjetivista, de base romântica, e supostamente fonte do simbolismo brasileiro, sem adentrar na defesa da religião estrita, como intentava Jackson de Figueiredo, por exemplo, interlocutor de nosso crítico ${ }^{105}$.

(...) O nosso verdadeiro catolicismo é apenas, no fundo, um simples cristianismo humano, muito humano, sem misticismo exagerado, mas credo, dentro de tais linhas, verdadeiramente simpático, pelo decoro que quase invariavelmente sabe manter, e pelo espírito de caridade que tem demonstrado tantas vezes seus representantes

105 Recordo aqui a amizade entre Farias Brito, Jackson de Figueiredo e Nestor Vítor e o fato de que o escritor católico também escreve sobre o pensador cearense em 1916 e em 1919. Conferir o breve comentário de Bosi (2006) sobre Jackson de Figueiredo em História concisa da literatura brasileira, p. 319-320. 
oficiais, em casos, não raro, até de grande beleza, como a nossa história e a nossa romântica registram (OC, vol. I, p. 228).

Repetindo as palavras de Antonio Candido ("todos os românticos, com poucas exceções, manifestam um ou outro avatar do sentimento religioso, desde a devoção caracterizada até um vago espiritualismo quase panteísta" (2000, p. 17)), diria que, com a leitura de Farias Brito, Nestor Vítor forja uma tradição que serve para legitimar o já decaído simbolismo e antecipar a valorização da ala espiritualista do modernismo brasileiro ${ }^{106}$.

Como a intenção de Nestor Vítor não nasce apenas de uma investida intelectual completamente "coerente", abstrata, portanto, mescla as disputas do passado, no campo literário, com resquícios do pensamento determinista e naturalista que ele acabara de negar, mas que já vinham expressos, ao menos, desde 1914.

Farias Brito, além disso, no bronzeado da tez, na deselegância e no desengonço do porte, no apagado habitual das suas maneiras, na monotonia de todo o seu modo de ser exterior, lembrava o tipo do sertanejo do Norte que Euclides da Cunha simbolizou no jagunço. (...) Mas, como este [o homem do sertão] é o brasileiro por excelência, porque é aquele que já se pode dizer o triunfante no que se refere ao penoso processo da nossa adaptação ao Novo Continente. Farias representa-nos como o nosso âmago, o que vale dizer na alma que já nos possa de verdade ser própria (ibidem, p. 228-9).

Como conciliar tendências que, a princípio, seriam universalistas, dado o caráter metafísico do espiritualismo, com critérios étnicos ou mesológicos que servem à construção de um "tipo nacional”? Nestor Vítor consegue-o afirmando que o brasileiro participa do universal ao revelar uma natureza não-materialista, "contemplativa", como ele dissera antes.

Dessa maneira, em uma espécie de harmonia entre o todo e as partes (os valores espirituais amplos e o caráter nacional), o crítico consegue uma fusão entre a nossa civilização e a civilização moderna. Fusão que não lembra "a falta de civilização" que antes ele denunciara em nosso meio cultural. O "nosso modo de ser" pode, agora, formular o "inefável" do "universal", porque este sempre esteve, na concepção essencialista de nosso crítico, afastado das mundanidades materialistas.

Ao mesmo tempo, entretanto, que a obra de F. Brito é assim a expressão do inefável, tanto quanto um brasileiro em nossa língua já pode formular, ela traduz como nenhuma de seu gênero, até aqui, o fervor das nossas crenças, a severidade da nossa ética e até o que possa haver de selvagem na nossa atitude moral, comparados que

106 No próprio ano de 1917, em março e em abril, Nestor Vítor escreve sobre os livros de Murilo Araújo, Carrilhões, e de Gilka Machado, Estados D'Alma, dois poetas muito elogiados pelo crítico e que viriam a publicar na revista Festa a partir de 1927. Conferir OC, vol. II, p. 85-86. 
sejamos como povo aos outros povos, no que constitui o verdadeiro Brasil, aquele que já pode ser considerado de fato como uma cristalização (ibidem, p. 218-9).

De uma maneira sui generis, o "pensamento mais alto", a "Inteligência", expressão do “Amor"107, reúne-se à manifestação da tradição nacional, do espírito nacional, e ganha identidade, fusão. Nacionalismo e espiritualismo tornam-se idênticos na compreensão de Nestor Vítor. E isso por um objetivo em mente, como afirmei: a "justiça" aos "espiritualistas" do final do século XIX, os simbolistas.

\begin{abstract}
Aliás, se Farias Brito entre nós se encontrou sozinho como filósofo propriamente dito, por modo que sob tal categoria terá de figurar isolado, quando se haja de fazer justiça aos iniciadores da nova corrente espiritualista no Brasil, não quer isso dizer que em nosso meio, fora da atmosfera caracteristicamente religiosa ou mística cuja existência ficou patenteada, não houvesse forças intelectuais que simpatizassem com sua obra.

Já é coisa reconhecida no mundo culto que os chamados simbolistas foram os batedores do neo-espiritualismo na Europa.

O simbolismo representa uma ressurreição sub-reptícia, a princípio inconsciente, da tendência romântica (ibidem, p. 237).
\end{abstract}

Aqui a ligação é explícita. Simbolistas são o elo posterior ao romantismo. Identificamse com este pelo uso da intuição e representam uma reação à negação do romantismo feita pela literatura realista/naturalista.

A partir daí, Nestor Vítor expõe com clareza o que entende ser a literatura simbolista e o papel de sua estética no jogo das artes. Vale a pena transcrever um longo trecho em que se verificam: (a) os antecedentes do simbolismo (os "mestres" e a "tradição"), (b) a assunção do estético no interior do movimento, (c) a posterior negação desse estético, (d) a consequência dessa negação que é a crítica negativa aos simbolistas, tomados como "nefelibatas", (e) a constatação histórica do esvaziamento do movimento e, por fim, (f) o sentido moral, teleológico, que estabeleceria mais um elo futuro, a partir da herança simbolista.

[a] Os simbolistas vieram exatamente assim. Representam eles uma reação contra todos os erros da literatura realista, - estreita aliada do cientificismo, inferiormente intelectualista, antimetafísico, prosaico por natureza. Estudando-se aqueles que se consideram os mais imediatos precursores do Simbolismo, Edgard Poe, Baudelaire, W. Whitman, Villiers de I'Isle Adam e outros, vê-se que eles já apresentam, mais ou menos definidamente, tais intuitos.

107 Curioso é que Nestor Vítor grafa esses substantivos abstratos, amor e inteligência, com letra maiúscula, como antes ele fazia nos textos do final do século XIX sobre os simbolistas, mas agora para se referir à filosofia de Farias Brito. No mesmo estudo, no entanto, ele rejeita o uso das maiúsculas ao se referir aos escritos do passado, afirmando se tratar de uma convenção juvenil sem sentido que os "nefelibatas" adotavam por moda. Mais do que "moda", o uso da maiúscula pode indicar a "inconsciência" do próprio Nestor Vítor no ato de aderir às modas: antes, o simbolismo; agora, o espiritualismo difuso. 
[b] A estética dessa nova escola é uma consequência da sua filosofia intuitiva. O fato dela criar em abundância tipos ou imagens que valham pela demonstração formal ou a representação adequada de seus sentimentos ou de suas ideias, não obedece a frio móvel racionalista como aconteceu com a literatura mística de antes do classicismo, literatura de que os autos religiosos de Gil Vicente são o reflexo mais interessante na nossa língua. Essa no seu simbolismo tinha sobretudo uma intenção moralista. O que porém, os simbolistas agora pretendem renovando tal processo, é dar extraordinário valor estético a tais sentimentos e ideias, valor que esteja em correspondência com a condição de maravilhados em que se acham eles, como se dava com os românticos, quando entregues ao seu demônio na febre da produção. (...) [c] Não percebem que dentro em pouco, por tal sistema, caem eles, como aqueles místicos seus antecessores, num formalismo hierático, árido, cansativo, extravagante, perdendo o legítimo senso poético. (...)

[d] No fundo, a razão de propenderem os simbolistas para tal esoterismo literário, deixando de entrar em contato por esse modo a massa dos leitores comuns, estranha a cabalas, incapaz de interpretações sutis, está justamente em que foram eles os prenunciadores instintivos de uma corrente de ideias ainda por criar. (...) Haviam de andar mais ou menos aéreos, baseados apenas em fugitivos, incompletas intuições: haviam de ser nefelibatas, como se ressuscitou o vocábulo para nomeá-los em certo momento.

[e] Por isso dentro em pouco chegavam ao limite da sua real capacidade inovadora, começando daí por diante a executar mal disfarçados ritornelos ou mais ou menos hábeis rapsódias epígonas. Por fim, foi o Simbolismo diluindo-se transigindo com o Parnasianismo e o Realismo, até com o defunto Romantismo, e o próprio classicismo arcaico, como estes com ele, na estética e até na ética própria a cada uma destas escolas, até que caiu na tolerância quase absoluta que era moda quando começou a Grande Guerra.

[f] Pouco importa, o impulso já estava dado: não tardou muito, veio o pragmatismo anunciar que a tentativa simbolista repercutira no mundo filosófico, começando este a dar os seus primeiros frutos consequentes dessa repercussão. (...)

O Brasil não se conservara estranho por muito tempo ao movimento reacionário dos simbolistas. Quando Farias Brito dava em 1895, lá em Fortaleza, o seu inicial volume de filosofia, já em 1893 Cruz e Sousa, o mais alto representante do Simbolismo na poesia do Brasil, publicara o Missal, no Rio (ibidem, p. 237-9, grifos do autor, com minha enumeração das partes).

O ciclo se fechava: a "filosofia espiritualista" de Farias Brito encontrara seu paralelo na obra simbolista de Cruz e Sousa. Para isso, em seu raciocínio, Vítor defende a identidade de "reação" tanto na literatura quanto na filosofia. As "correspondências" ocorreram em um plano que Nestor Vítor busca revelar nesse texto de 1917, alimentando assim uma interpretação idealista do desenvolvimento histórico da literatura e da filosofia no Brasil. Chega, inclusive, a citar longos trechos da monografia Cruz e Sousa (1896/1899) com o objetivo de demonstrar que havia uma coincidência entre as ideias de Farias Brito "sobre a arte e sua missão" com as suas próprias “intuições juvenis” (ibidem, p. 243).

O mais interessante, diria, dessa nova interpretação e dessa suposta coincidência entre os pensadores é a revisão do papel do estético na série literária. No trecho, o "valor estético" que os simbolistas empregaram em seus "processos" aparece como uma fase que seria, necessariamente, superada em seguida. A fase "estética" não seria uma conquista definitiva. $\mathrm{O}$ 
círculo fechado pode ser pensado assim em termos de predomínio dos valores empregados em relação à arte: o valor moral que antes existira no "simbolismo" da literatura de Gil Vicente, citado, assume "extraordinário valor estético" para os simbolistas, mas essa "fase estética" sucumbiria porque seria inconsciente, conformando o "nefelibatismo" dos artistas simbolistas. A filosofia de Farias Brito seria a face consciente da reação espiritualista, nascida após essa fase. O pensador cearense voltar-se-ia ao valor moral, abandonado pelos nefelibatas. A vitória da reação espiritualista contra o materialismo colocaria em segundo plano o valor estético.

Vê-se aí que, por força da Grande Guerra, da crítica ao materialismo cientificista, do surgimento do espiritualismo militante, Nestor Vítor estabelece uma relação entre o idealismo filosófico e o simbolismo literário do passado. Cria, assim, uma identidade forçada de autores (Cruz e Sousa e Farias Brito) a partir de um jogo de intenções (a oposição ao materialismo em literatura e em filosofia). No entanto, na comparação atual, nesse fim dos anos de 1910, é o caráter estético da literatura simbolista que sai perdendo, porque o que haveria de mais original nos simbolistas, o seu "formalismo hierático", logo se desgastaria, permanecendo o “movimento reacionário", centrado nas ideias e não na arte já gasta. Portanto, a função estética da arte simbolista do final do século XIX se subordinaria a uma finalidade moral: combater o materialismo cientificista. Este seria o grande legado do simbolismo brasileiro para o próximo período. Esta parece ser uma das conclusões importantes do estudo Farias Brito: a subordinação do estético ao mundo social, ou ao "mundo moral", como mesmo manifesta Nestor Vítor.

Ainda por essa perspectiva, o pensamento de Farias Brito serviu a Nestor Vítor para reavivar a crítica ao cientificismo naturalista, mas agora não a crítica no plano da "política literária” dominada pela Academia Brasileira de Letras, por exemplo, ou a crítica no plano do "literário" ao julgar a "vulgaridade" ou a "mundanidade" dos textos naturalistas e parnasianos, mas sim no plano da moral, da suposta degenerescência da cultura a partir do argumento da não correspondência do objetivismo materialista (expresso nas estéticas naturalista e parnasiana) com o espírito nacional; este tomado como "contemplativo", “inativista", subjetivo, portanto. A crítica à política literária ou à vida e obra dos parnasianos e naturalistas atua, em certa medida, na defesa da autonomia da arte e da literatura, o que não se vê nesse texto de 1917.

Nesse plano, o do "mundo moral", como seria de esperar, o próprio simbolismo é relido e suas "excentricidades" são rechaçadas. A caracterização dos escritores como 
"maravilhados" ou "nefelibatas", como visto nos textos anteriores, é a aceitação da crítica oficial ao simbolismo. O nefelibata e o maravilhado estão em estado de não participação efetiva com o contexto social, não participam do movimento interno da cultura brasileira, como aparecia na crítica de Sílvio Romero, Araripe Júnior e José Veríssimo.

Do mesmo modo, o individualismo universalista do artista, lido sob a chave do isolamento do "Poeta" e seu cosmopolitismo, precisa ser rejeitado nesse novo momento.

De fato, o escritor deve participar de um projeto nacional e deve se preocupar com o efeito moral de seu texto. Postura que é ilustrada por alguns dos artigos presentes em Cartas à gente nova, publicado em 1924. Há, de uma forma sutil, a imputação de uma responsabilidade ${ }^{108}$ ao escritor, ao homem de letras. Uma imputação que se baseia, em Nestor Vítor, em uma sanção moral e não legal, pensando na distinção dos "tipos de responsabilidade" que Sapiro (2011, p. 14) busca apreender em seu livro.

Posso citar, inicialmente, como exemplo dessa postura um trecho de uma carta de setembro de 1919 sobre livro de Monteiro Lobato, em que implicitamente a uma reprimenda ao modo como o escritor construía suas personagens; censura que nasce de uma projeção em torno do Brasil:

\begin{abstract}
É preciso, não tem dúvida, impedir que o grande e incontestável sucesso de livraria obtido pelo brilhante livro de contos de Monteiro Lobato [Urupês] perturbe a nossa orientação no que respeita ao modo por que devemos encarar o caboclo. Este é o músculo de resistência verdadeiramente brasileiro com que podemos contar. Se o desmoralizássemos, por isso mesmo implicitamente proclamáramos de modo antecipado e estúpido a dissolução do Brasil (OC, vol. II, p. 158).
\end{abstract}

O texto, no entanto, que melhor expressa essa posição de Nestor Vítor é a longa carta que escreve em torno do romance de Breno Arruda, Flor de Manacá. A carta é de 22 de dezembro de 1921 e, ao defender um tipo de literatura nacional, evoca a tradição romântica e avalia a posição de realistas/naturalistas e a dos simbolistas na evolução de nossa literatura, destacando os perigos da influência estrangeira e a falta de observação de uma moral condizente com o público leitor brasileiro. Vejamos alguns extratos desse ilustrativo texto.

Vítor começa a carta com o elogio "daquela música interior tão brasileira que há em nossos românticos, os do verso, como os da prosa" (OC, vol. II, p. 186) que se observava em

108 Carvalho (1998) também vê que Nestor Vítor imputava ao escritor uma responsabilidade moral: "Para Nestor Vítor, ainda, o intelectual, o escritor teria para si uma árdua missão. (...) Tal tarefa seria a de salvaguardar tudo o que a humanidade havia conquistado até então, representado na moral e nos ideais estéticos, mesmo que sentisse que eles iam se tornando insuficientes ou anacrônicos (...)" (CARVALHO, 1998, p. 105). 
um novo poeta, Pereira da Silva e que já havia sido estudado também por um jovem, Tasso da Silveira. Seguindo Tasso, aproveita para criticar os naturalistas que estão "longe" dessas características [música interior e maneiras ingênuas] e também os simbolistas do verso, "fato que infelizmente revela como tais autores se afastaram de seu povo" (ibidem, p. 187). Segundo Vítor, isso se explicava pela influência do estrangeiro que se fizera exagerada.

Apoiando-se, em seguida, em estudo de Breno Arruda sobre Adolfo Caminha, ratifica a posição do autor ao indicar que a estética dos naturalistas nunca correspondeu ao temperamento de "nossa raça", uma "raça idealista". Além disso, a "moda realista e simbolista" foi atravessada pela popularidade nunca contestada dos autores românticos: "Basta que se consultem as contas de venda nos livreiros" (ibidem, p. 187). A citação do trabalho de Arruda serve para expressar o ponto de vista de nosso crítico sobre o romance do autor: “(...) Flor de Manacá, representaria, quando nada, uma bem nítida tentativa de reação contra os processos artísticos daqueles que entendias contrariarem a nossa índole nas obras de ficção" (ibidem, p. 187).

Entretanto, não quer Nestor Vítor defender uma completa volta ao modelo romântico porque ele entende que os neorromânticos no verso como Pereira da Silva são também neossimbolistas, porque este “(...) recorda até certo ponto sobretudo Fagundes Varela, (...) um Varela que viveu, por constante lição, com E. Poe, com Baudelaire, com [Albert] Samain, com [Georges] Rodenbach, com Antônio Nobre, com Cruz e Sousa, com Emiliano Perneta (...)" (ibidem, p. 188). Do mesmo modo, na prosa de ficção, não se pode querer uma volta completa ao modelo de romance de José de Alencar, porque houve depois um Machado de Assis. O que se extrai da evolução de nossa literatura, segundo Vítor, é o valor dos nossos românticos, mais perenes que os demais escritores.

(...) Alcançarias que justamente em razão de já vermos também um tanto a frio essas duas últimas correntes é que podemos, em todo caso, ir sentindo melhor os nossos românticos e reconhecendo que eles ao menos têm o grande valor de haverem sido os primeiros e os únicos, até aqui, a falar uma linguagem mais nossa, no íntimo porque falaram mais do que outros quaisquer com a nossa alma, e por isso com a música interior que nos é própria? (ibidem, p. 188).

A lição dos românticos é que deveria ser aprendida ${ }^{109}$. A tarefa dos jovens escritores seria "apenas desestrangeirar-nos o quanto pudermos, aproximar-nos da nossa gente como os

109 Na interpretação de Silveira (2010), a "retomada de escritores românticos se dá por uma revalorização deste passado, usando-o como uma espécie de 'porto-seguro' pelo qual poderiam ser assentados novos valores para um mundo em processo de desmoronamento causado pela Guerra” (SILVEIRA, 2010, p. 133). 
românticos se aproximaram” (ibidem, p. 188), contribuindo assim para integrar a nossa literatura que ainda se forja à "psique nacional".

Para Nestor Vítor, os naturalistas errariam duas vezes. O primeiro erro, por um excesso de influência estrangeira; o segundo, por negarem a "verdade na arte", que é representar o "ideal no real”: “(...) O naturalismo errou, e hoje paga o seu erro, pela estreiteza de vistas com que imaginou o verdadeiro, como se viu acontecer com o romantismo, mas este pelo modo falso de conceber o que fosse idealização" (ibidem, p. 189).

Esse segundo erro, no entanto, figura de forma menor, já que o primeiro, ligado ao ideal nacionalista em literatura parece ser fundamental, como ele evidencia nos vários parágrafos após esse trecho, em que relaciona o nacionalismo e o contexto pós-Guerra e assume o discurso de responsabilidade dos homens de letras.

\begin{abstract}
Atravessamos uma hora em que as nacionalidades ou já estão passando ou irão passar daqui a pouco por crise tremenda, hora em que elas vão ser experimentadas de maneira tal, que só as mais vivedouras é que ficarão de pé.

(...) As pequenas pátrias são as mais arriscadas, ou então os países grandes, mas cujos membros, até o mais extremos entre si, se não solicitem necessariamente, como o ímã atrai o aço, solicitação que só se dará se tais membros se parecerem uns com os outros como nenhum deles com qualquer parcela estranha à comunidade que atualmente os entrelaça.

A geração atual tem, pois, sobre seus ombros uma responsabilidade formidável. sobretudo nas terras cuja organização ainda se processa.

Vem daí o movimento nacionalista que por toda parte se está produzindo, e, por instinto, refletindo em quase todas as manifestações artísticas.

Antes, mesmo, da grande guerra já se vinha iniciando ele, no Brasil. (ibidem, p. 189, grifos meus)
\end{abstract}

Como se vê, um moralismo nacional difuso é o que defende Nestor Vítor. A referência à Grande Guerra de 1914 e seus antecedentes mostra o quanto ele estava influenciado pelo espírito de "nacionalismo ativista" a que antes me referi ${ }^{110}$ e que ele próprio chega a enunciar, ao enumerar escritores “interessados pelas nossas cousas e os nossos problemas' (ibidem, p. 190):

De Graça Aranha, Euclides da Cunha, Alberto Torres, Rocha Pombo e implicitamente Farias Brito, para cá, é que, porém, tal interesse passou a ganhar certo ardor, que o tornou lírico ou épico, até místico, como observei escrevendo sobre o derradeiro desses autores.

Esse forte sopro poético e esse misticismo (o último entendido à moderna) é que nos fazem ir entoando instintivamente com os românticos, os quais, aproveitando o grande arranco facultado em todo ocidente à hora literária e artística em que surgiram, puderam ser corajosamente brasileiros, como ainda não se fora até então (ibidem, p. 190).

110 Conferir o primeiro capítulo de 1922 - Itinerário de uma falsa vanguarda, particularmente o roteiro de livros da década de 1910 que apontam para um novo tipo de nacionalismo (PRADO, 1983, p. 22-27). 
Em sua visão, a "coragem" de ser brasileiro marcou os românticos e marcava autores do século XX, como Farias Brito ou Alberto Torres, não literatos, mas homens preocupados com as questões de seu tempo, de sua "hora". Naturalistas também se preocuparam com as questões nacionais, conforme reconhece Nestor Vítor. Eles, no entanto, segundo o crítico, sofreram a "influência de certas ideias, preconceitos e processos tomados de boa fé, mas funestamente, aos estrangeiros" (ibidem, p. 190).

O nacionalismo de Nestor Vítor é, de fato, uma moral porque não se trata de defender todas as manifestações nacionais, mas aquelas que não nos fazem perder o "sentimento de medida", isto é, uma imagem cristalizada de como deveria ser representado o povo brasileiro. O crítico, por exemplo, olhava com suspeita o regionalismo que se propagava em livros de Afonso Arinos (1968-1916) ou Catulo Cearense (1863-1946), os quais, "falsificando, com a melhor intenção, nos próprios salões, a linguagem matuta, e misturando no teatro o velho 'maxixe' obsceno com a 'chimarrita' dançada de tamancos sob grandes chapéus de palha e com caras aparvalhadas, como se dança la na roça em casa de 'seu coroné”” (ibidem, p. 191).

É um moralismo nacional porque a imagem do Brasil que se quer construir é também de um Brasil culto, caso contrário "não faremos mais do que praticar, então, um alucinado bolchevismo literário, anarquizando a nossa tábua de valores, com o aplauso e a colaboração de estrangeiros de falso gosto (...)" (ibidem, p. 191). Trata-se, portanto, de um "nacionalismo corajoso, embora bem entendido e são" que não se satisfaz "com a glória de produzir esses 'gênios' analfabetos ou propositadamente barbaristas e solecistas" (ibidem, p. 191). Resulta daí uma tarefa aos escritores: “(...) a obra que cumpre à geração atual é, sobretudo, ver se tomamos posse de nós mesmos, mas justamente por ganhar a consciência do que somos de fato, sem deprimentes preconceitos bebidos na falsa ciência (...)" (ibidem, p. 191).

Assim, Nestor Vítor concilia o novo credo, nacionalista, com a antiga crítica ao cientificismo naturalista e com a nova leitura do simbolismo, como reação espiritualista, conforme ele expressa ao falar do talento de Breno Arruda e de suas filiações.

O que procuras, em última análise assimilar do autor de Cinco Minutos e d'A Viuvinha é o seu genuíno brasileirismo, na extraordinária simpatia, no carinho que nossa terra e a nossa gente lhe inspiram (...).

Se consegues muito, porém, em tal sentido, sem prejuízo da verdade, é porque tua idealização é mais perfeitamente orientada que a da escola a que Alencar e Macedo se filiaram, mas, além disso, também porque tua concepção do verdadeiro é muito outra que não a que trouxeram os homens do naturalismo. Entre estes últimos e a nova geração não se meteu embalde o simbolismo de permeio. Este, fosse como fosse, levantou as almas por modo que em literatura ser materialista hoje é ser míope, embora ainda não se exija um espiritualismo bem definido e muito menos 
sujeito a dogmas. O teu, com o otimismo e humanismo que te distinguem, creio que participa dessa feição vaga e dessa perfeita liberdade, mas nem por isso deixamos de senti-lo. E é, acho eu, porque suficientemente já o percebemos que podes ter uma visão das coisas e dos seres, ainda mais dos seres humanos, em que já não sentimos só muita simpatia, mas até certo ar de doçura, de bondade, talvez de piedade cristã (ibidem, p. 193, grifos meus).

Ainda que o espiritualismo de Nestor Vítor não seja confessional, aqui, como em muitos momentos de sua obra, ele só pode constatar que esse "espiritualismo" pouco definido relaciona-se com um suposto religiosismo "do nosso povo". Por essa via, ele resgata certos valores do romantismo brasileiro e salva o simbolismo do caráter estrangeiro e passageiro (de moda, como se referira) que lhe fora imputado por outros. $\mathrm{O}$ vago espiritualismo ligaria as correntes literárias e reafirmaria um suposto modo de ser brasileiro, atacando também a suposta artificialidade e amoralidade do "materialismo" dos escritores naturalistas.

Foi a filosofia materialista e foi a perda até do respeito às nossas crenças tradicionais, que levaram um Aluísio Azevedo, um Júlio Ribeiro, um Adolfo Caminha a olhar aos seus personagens, até os femininos, com a dureza, senão a brutalidade, que tinham os pintores realistas seus coetâneos, impondo indecorosas posturas aos modelos que lhes caíram nos ateliers, apanhando as mulheres às vezes só pelas nádegas, ou, quando muito, acusando-lhes o rosto, mas frequentemente coberto por basta cabeleira que ao menos assim, não sei se contra os cálculos rasteiros daqueles fanáticos do nu, salvava-lhes o pudor, inseparável do sexo.

(...)

Por esse modo reatas a série de obras que mais normalmente representam a nossa romântica, e que o demonstram sendo as preferidas pelo nosso público ainda imune de esnobismo - pelas mulheres, antes de tudo, que afinal é para quem os romances, as novelas mais particularmente se destinam (ibidem, p. 194).

Depois de pincelar essa visão moral sobre a literatura naturalista, o que poderia também lembrar a dos moralistas franceses que atacavam os processos do naturalismo ${ }^{111}$, Nestor Vítor volta a citar o "grande cataclismo de 1914" que teria sido responsável por modificar a visão dos literatos a exemplo de Graça Aranha, permitindo adotar uma fé maior nos povos de "origem neolatina" (ibidem, p. 194-5).

Vítor termina a longa carta a Breno Arruda separando com alguma consciência os valores desse moralismo nacional e o valor estético propriamente dito da obra ao afirmar que "Flor de Manacá (...) não se pode medir com essas obras culminantes [como Graziela de Lamartine]", já que o livro "ainda é modesto, na sua execução (...)", mas que vem "perfeitamente nacional”, marcando, "em seu gênero, a volta dos moços letrados para o modo simples de ser do nosso povo" (ibidem, p. 195). E que a obra é "novela realizada", de modo 
que "ainda por seu lado estético ela, conseguintemente, justifica os vivos aplausos e animações que vais colhendo" (ibidem, p. 195).

Ou seja, o "moralismo nacional" de Nestor Vítor não nega completamente a visada estética, contudo, pela dimensão que toma nesse texto por exemplo, acaba por subordinar a leitura dos aspectos propriamente literários da obra a objetivos exteriores, como a responsabilidade difusa do escritor com o "nacionalismo corajoso" ou com o efeito moral de seu escrito.

De maneira textual, Vítor já havia, inclusive, em dezembro de 1918, um mês após o fim da Primeira Guerra, se referido ao "efeito moral" da literatura em uma outra carta também publicada em Cartas à gente nova. Esta era uma carta que se dirigia a Ranulfo Prata em razão do lançamento de seu livro $O$ Triunfo.

O livro de Prata é visto como um "pasticcio naturalista", fruto de uma mentalidade cujo "efeito moral", em última instância, foi ter produzido a Grande Guerra que acabara há pouco.

\begin{abstract}
Só lhe falta uma coisa essencial: é casar a sua sensibilidade com a da sua geração. $O$ Triunfo é um pasticcio naturalista, e o naturalismo já de há muito passou. O senhor precisa sofrer e sonhar com os seus companheiros de idade em comunhão perfeita para pôr o seu relógio na hora. Já não se trata mais de contar aos leitores patifarias de parvenus e rastaqueras a fim de escandalizar as almas ingênuas e dar-lhes uma impressão repugnante da vida, sem nos preocuparmos com o efeito moral dessa falta de caridade. Tal orientação já produziu os seus frutos. Foi o materialismo que criou a situação tremenda em que hoje se acha o mundo inteiro (ibidem, p. 130, grifos meus).
\end{abstract}

A "hora" atual, segundo Nestor Vítor, é moral, e, como no passado, os escritores devem "ajustar" o seu relógio à hora. Os jovens escritores devem se irmanar, portanto, com as pretensões nacionalistas que a Grande Guerra fez surgir na intelectualidade.

A partir desta postura, nessa última fase de sua obra, Vítor se aproxima de ideias que, no final do século XIX, na França, Sapiro (2011) identifica como imputadoras de uma responsabilidade objetiva do escritor, a exemplo da teoria de Jean-Marie Guyau cuja obra de 1887, L'art au point de vue sociologique, critica "la littérature qui se confine à un cercle d'initiés, de gens de métiers et d'amateurs" (SAPIRO, 2011, p. 436). Na concepção do pensador francês, a arte deve ser consciente de seus efeitos, do contágio de estados psicológicos que cria e desenvolve artificialmente. Assim, critica-se tanto a arte "realista" e seus "vícios" quanto a arte dos decadentes e dos simbolistas, cujos extremos acabou por acentuar o individualismo, dissolvendo os sentimentos sociais (ibidem, p. 436-7). 
No caso de Nestor Vítor, o paralelo pode ser estabelecido se pensarmos que a arte simbolista de final do século XIX, voltada a um círculo de iniciados, que o crítico antes defendera, não poderia ter sucesso no momento atual, de maior integração "nacional". Se antes a "estética" pode ter sido um "ética profissional"; nesse momento, as preocupações morais/nacionais atuavam como guia das avaliações, servindo também como critério de valor no julgamento das obras de arte.

Afirmo "também como critério," porque, embora muitas vezes predominante, como nos textos até aqui analisados, as diretrizes nacionais/morais não negam completamente o valor das obras ou dos autores, o que já distingue Nestor Vítor de um simples moralizador da arte e da literatura ${ }^{112}$.

A apreciação que ele faz, por exemplo, de Urupês de Monteiro Lobato, cujas personagens desagradavam em relação a uma certa imagem do país, não representando o que ele supunha ser o "sertanejo brasileiro em geral", não invalidavam a leitura do escritor, porque, segundo ele:

(...) o maior motivo de Urupês ter-se quase equiparado em sucesso real a $O s$ Sertões de Euclides da Cunha e a Canãa de Graça Aranha, ficando, portanto, muito acima de outros modernos livros de literatura regional, é que, como esses dous outros, ele resulta de uma sensibilidade propriamente nova, a sensibilidade neo romântica, em que o misticismo atua poderosamente, correspondendo à solicitação, embora talvez ainda inconsciente, do momento em que estamos (OC, vol. II, p. 159).

Ou seja, a imagem de Brasil que Nestor Vítor alimenta é amalgamada às solicitações de uma escrita que ele valorizava e que atualizava aquela que, no passado, ele defendeu: uma literatura de contornos "místicos", lida, nessa nova fase, como neorromântica, neossimbolista ou espiritualista. Não há, assim, uma adesão completa ao critério nacionalista, atualizado pelas circunstâncias do mundo pós Primeira Guerra Mundial, nem uma adesão irrestrita ao critério moral na avaliação das obras. Permanece como substrato de suas avaliações as antigas ligações com a literatura "místico-simbolista" do final do século XIX e com uma "tendência" ao julgamento estético da literatura.

112 Isso fica claro ao elencar alguns anos depois, em 1922, escrevendo sobre o livro de crítica de Andrade Muricy, O Suave Convívio, os critérios do novo crítico, fazendo o elogio desse amálgama de posturas, desde a preocupação com o "estético" a preocupação com o "efeito moral": "Dá-se ainda que à tua crítica lhe interessa mais do que tudo a beleza da expressão e o efeito estético, embora também o efeito moral que com isso os autores irão produzir ou já produziram em dado ambiente" (OC, vol. II, p. 241). 
Esse novo quadro de critérios avaliativos seguirá até o final da produção crítica de Nestor Vítor, como se vê, por exemplo, no artigo "Raul de Lêoni", publicado após a segunda edição da obra Luz Mediterrânea (1928).

Nesse texto, Vítor encara o poeta Raul de Leoni (1895-1926) como um representante de um esteticismo que em, última análise, era "amoralista" e vizinho da estética parnasiana.

\begin{abstract}
Dos parnasianos, que acabaram na arte pela arte, o que é um eufemismo, sobretudo no Brasil, onde eles caracteristicamente antes foram amorais do que simples joalheiros encantados com o ritmo e com a rima ou com a cor, deles, para os esteticistas, a cuja família pertence Leoni, não vai grande distância. Do amor pela arte para o amor do estético pelo estético a transição é natural, tanto mais quando a estes, vindos depois dos outros, se ligam pelo sensualismo e pela amoralidade (OC, vol. II, p. 292-3).
\end{abstract}

Por uma aproximação sutil, a antiga crítica aos realistas/naturalistas se atualiza na crítica ao "esteticistas": todos resvalam para a amoralidade, isto é, não se preocupam com os efeitos de sua arte, ainda que esta possa ter valor estético como assegura Vítor sobre a obra de Raul de Leoni. Isso porque os "estetistas" estariam a meio passo entre parnasianos e simbolistas:

\footnotetext{
Mas, se por um lado os estetistas não vieram de costas para os parnasianos, prendendo-os a estes até certo amor ao classismo (...), por outro, amando o pensamento, embora tragam também um fundo voluptuário, eles até em parte se confundem com os adversários da gente do Parnaso, que são os simbolistas. Há sonetos em Raul de Leôni que fazem lembrar os de Cruz e Sousa (ibidem, p. 293).
}

Assim, nos anos de 1920, quando nosso crítico escreveu sobre Leoni e outros poetas surgidos no período, a constatação da "morte" do simbolismo é serena e, ao contrário do começo do século, ele já consegue vislumbrar os novos rumos da literatura brasileira e mundial.

As vanguardas europeias e a divisão dos artistas em dois grupos (de um lado, Guilherme de Almeida e Mário de Andrade, da revista Klaxon e, de outro, Tasso da Silveira e Murilo Araújo, da revista Festa, por exemplo, citados no texto sobre Raul de Leoni) é algo nítido para Nestor Vítor. A tradição se reorganiza com base nOs de hoje, título da sua última obra, já póstuma ${ }^{113}$, mas se reorganiza a partir do quadro que o crítico trazia de seu passado.

113 A obra publicada em 1938 traz um Prefácio dos editores em que se afirma: “O espetáculo que Nestor Vítor apresenta ao Brasil, neste volume (que em vida começara a organizar, e a que já dera o título que tem) é dum interesse inapreciável. (...) Com que olhos despreconceituosos ele encara essa geração enfant terrible do Modernismo!" (OC, vol. II, p. 265). 
Assim é que lerá o "vanguardismo" da geração modernista: "O vanguardismo, porém, entre nós, ou vem do simbolismo ou vem dos parnasianos" (ibidem, p. 294).

A responsabilidade moral a ser observada, a imagem do Brasil a ser valorizada e a crítica da poesia a ser feita nos anos de 1920 subordinam-se, desse modo, ainda, à chave das antigas disputas no campo literário do final do século, entre simbolistas e parnasianos. O que não significa dizer que Nestor Vítor não enxergou qualquer especificidade nos autores dos anos 20. A leitura que se materializa no livro Os de hoje é prova da capacidade do crítico em observar os novos rumos da literatura com a "simpatia" que ele acreditava essencial ao ato crítico. Ele próprio, no entanto, reconhecia que o seu olhar era "passadista": “eu já começo a viver mais da vida que por qualquer modo suscitei do que daquela que pessoalmente ainda represento neste mundo" (OC, vol. II, p. 260). Afirmava isso em 1922 ao avaliar a obra $A$ igreja silenciosa de Tasso da Silveira, e citar os futuristas da Klaxon, a exemplo de Oswald de Andrade.

Um ano depois, em 1923, ao organizar as obras completas de Cruz e Sousa, reforçará esse novo quadro de critérios ao ler toda a produção do poeta no estudo "Cruz e Sousa"114.

Por se tratar de um estudo introdutório, apresenta aos leitores toda a biografia e as principais influências do poeta, bem como o contexto de produção e recepção das obras ocorridas há mais de vinte anos. Em uma leitura totalizante, quer transmitir a ideia de evolução que a poesia do escritor teria alcançado, saindo das influências originalmente românticas e posteriormente parnasianas, confirmando a estética simbolista, até chegar a uma poesia de "feição nitidamente cristã" (VÍTOR, 1979, p. 143).

Sobre Missal afirma, por exemplo, tratar-se de obra de transição "do naturalismo para o simbolismo" que poderia ser valorizada por seu significado enquanto reação subjetivista, espiritualista àquela hora, marcada pelo cientificismo:

(...) efeito que produziu na sua hora, que é muito legítimo, marcando esse livro o nosso primeiro passo, no mundo do espírito, em direção ao novo horizonte que o simbolismo intuitivamente entreviu e que de dia para dia parecendo mais vasto aos olhos dos que andam realmente entregues à vida do pensamento (ibidem, p. 127)

E também poderia ser valorizada por seu vínculo com o "frescor" da realidade brasileira, também entrevista ali ainda que "transfigurada" pela estética simbolista: "Entre

114 Como dito, este texto não pertence à Obra Crítica de Nestor Vitor, organizada pela Fundação Casa de Rui Barbosa. Trata-se, na verdade, da introdução de Nestor Vítor às Obras completas de Cruz e Sousa, da editora Anuário do Brasil, de 1923. Utilizo aqui a reprodução efetuada por Afrânio Coutinho em Cruz e Sousa. Coleção Fortuna Crítica, 1979, p. 104-145. 
elas [as páginas de Missal] têm vivo relevo e frescura até hoje, sobretudo, pelo menos para o gosto geral, as que nos falam da natureza encantadora onde o autor nasceu e que deixara não havia muito (...)" (ibidem, p. 127).

Como se vê, o critério de identificação da obra com o espaço brasileiro e o valor histórico de reação "no mundo do espírito" ganham relevância na releitura que faz de Missal. No caso de Broquéis, saído a lume também em 1893, Vítor afirma se tratar de obra de um "simbolista feito". Passo, portanto, superior ao que representou Missal e que se expressa também em algo de "mais intimamente espiritual”: "Há em Broquéis um misticismo que nasce de prônubo estado d'alma verdadeiramente peregrino. Aí como que o próprio alvoroço da carne se transmuta em castidade quase virginal, quase que de outras esferas..." (ibidem, p. 131).

A leitura primeira sobre Cruz e Sousa, sob a chave da "Religião da Arte", não é negada completamente mas se vê que o "misticismo" se colore de um espiritualismo cristão. Assim também Nestor Vítor lê Evocações, que é “de certo modo um livro de Jó” (ibidem, p. 133).

Como em 1914, Vítor, ao falar de Evocações, analisa o poeta criticando os aspectos mais propriamente estéticos do simbolismo e a suposta influência racial de sua condição:

(...) se seus recurso líricos e dialéticos multiplicam-se, intensificam-se, também seus
defeitos de escola, como escritor, a relativa insuficiência do seu preparo e as
próprias taras de raça, inevitáveis, que sua organização psíquica e moral acusa (...)
Por tudo isso, fora as páginas combativas ou de doutrina, que são muitas além das
do "Emparedado", outras, de criação mais propriamente dita, saem-lhe arrojadas,
ciclópicas, como estátuas que talhasse a fundos e largos golpes, mas entre essas
algumas de gosto pessoalíssimo, discordes com nossos sentimentos estéticos (...)
Certas, contudo, do mesmo gênero lhe vêm da pena em horas mais ingratas que
criam cenas de dramalhão satanista, ou, então, ora representando produtos de
extravagante decadismo, ora prolixas, sem gradação, de um nefelibatismo pessoal
(ibidem, p. 134).

As palavras introdutórias às obras completas do poeta que deveriam, em geral, ser laudatórias ganham um tom de censura, como a distanciar por completo a "simpatia" original de Nestor Vítor, que escrevera seu estudo primeiro sobre Cruz e Sousa (1896/1899) sob o impacto da leitura de Evocações e o crítico dos anos 20, que repete velhos lugares-comuns da crítica oficial à poética de nosso simbolista:

Se esse defeito [o impessoalismo à Flaubert], no entanto, desaparece, e até a ideia total da "arte pela arte" vai se esbatendo por maneira a quase não restarem mais vestígios delas nos Últimos Sonetos, o verbalismo excessivo converte-se, mormente em Evocações, com frequência num palavreado que, casando-se a extremas 
liberdades de linguagem e de estilo, chega, na verdade, a ser intolerável, tanto mais que, não raro, obscurece quase por completo o sentido da frase (ibidem, p. 134-5).

A “impressão dolorosa” que provoca Evocações lembra, segundo Vítor, a dos escritos de fanáticos religiosos do início da era cristã, a exemplo de Tertuliano. A aproximação ocorre, contudo, por outro "fanatismo, o fanatismo da Arte". Como em 1914, o caráter de exceção do poeta é que parece vir em primeiro plano.

Esse caráter de "exceção" - que só poderia ser explicado por uma espécie de patologia, de "anomalia" moral, pelo poeta se "emparedar em seu meio" - tem sentido, na visão de Vítor, por se tratar de "um negro que quase todos negam, que quase todos riem, desde que ele se proclama poeta" (ibidem, p. 135). Ou seja, o crítico, saindo assim de um determinismo naturalista passa para um sociologismo vulgar, explicando o caráter excepcional da poesia de Cruz e Sousa. Repetindo ainda interpretações de 1914, encara o livro Evocações como fruto de uma elevação que não resulta apenas de "uma inovação estética" mas de uma "missão transcendental, apostólica" (ibidem, p. 135-6), o que confirma mais uma vez o caráter de exceção do poeta simbolista.

Por esse prisma, ainda que por um "caminho tortuoso", a obra de Cruz e Sousa, como a própria obra de Nestor Vítor, estaria voltada a se confrontar com a mesquinhez do meio, com a cultura dominante. Nesse ponto, a leitura do poeta por nosso crítico volta a respirar certo ar cosmopolita ao denunciar que "esse pobre homem teve por destino nascer aqui, num recanto do mundo, que, de fato, por seus defeitos, ainda é uma colônia ante as metrópoles de tal civilização" e que, apesar dessa condição de homem de uma "colônia", "é comparável" ao poeta Rimbaud, "filho do mais civilizado país do mundo" (ibidem, p. 136). Esse cosmopolitismo que permite comparações extravagantes é o mesmo, porém, que repete o credo racista ao afirmar que o poeta é "africano de origem, é negro sem mistura, quer dizer, de uma raça primitiva, cujo canto rude e tosco, lá no continente onde habita, só figura, como por ironia, em folclores, de caráter científico" (ibidem, p. 136)

É essa mistura de critérios que o faz ler também Faróis como a "estranha ária acompanhando correspondentemente Evocações - aquele livro de Jó, desse Jó da literatura" (ibidem, p. 136). A diferença é que Faróis vale sobretudo por sua música e não tanto por sua mensagem. Na leitura dessa "música", contudo, materializam-se os diferentes critérios adotados por Vítor e não propriamente uma leitura "interna" dos versos: 
(...) Valem predominantemente por música, por música pessoalíssima, solene, torva, entre a toada de um salmo e a de um réquiem litúrgico, ao mesmo tempo com maravilhas da música moderna, casadas, no entanto, com aquela monotonia, lembrando o banzo, do selvagem e torturante candomblé (ibidem, p. 137).

Como interpretação plausível, aqui Nestor Vítor lembra a leitura que José Veríssimo já em 1907, nove anos após a morte do poeta, publicava em livro:

\begin{abstract}
E são assim todos os seus versos. Tem a monotonia barulhenta do tam-tam africano. $\mathrm{O}$ homem que os fez, devia ser extremamente sensível às grandes sonoridades ruidosas. Seu ouvido não seria feito para a música de câmara, (...) mas eu imagino como se lhe dilataria a alma, à audição dos grandes trechos de orquestra, cheios de cobre sonoros e das zabumbas e tambores estrepitosos. Uma fanfarra, bem vibrante, devia deliciá-lo (VERÍSSIMO, 1977, p. 232).
\end{abstract}

Com efeito, a impressão subjetiva e eivada de preconceitos predomina em uma e outra das leituras, não fundamentadas por uma análise detida dos versos da poesia do escritor. Mas, de forma divergente, enquanto José Veríssimo chega a conclusão que Cruz e Sousa é um grande poeta, mas um isolado, Nestor Vítor reconhece a tradição que o poeta negro instaurava. Mais do que isso, para além da "revolução em nossas letras", Cruz e Sousa em seu livro, Últimos Sonetos, teria, segundo Vítor, ingressado definitivamente em nossa tradição por se aliar ao espírito de nosso povo: "Ele parece aqui mais realizado porque só aqui se conjuga melhor com o gênio do nosso povo" (VÍTOR, 1977, p. 143).

No final do estudo, Nestor Vítor caminha fortemente para a visão que conformava sua crítica nos anos de 1920 e que delimitava a sua perspectiva em torno do simbolismo e da obra de Cruz e Sousa.

Segundo o crítico, abandonando os "excessos" da estética simbolista, Cruz e Sousa, em Últimos Sonetos teria ficado "por esse lado mais nosso, mais dentro da moldura nacional" (ibidem, p. 142). Verifica-se aí a unidade que Nestor Vítor constrói entre simbolismo, espiritualismo e nacionalismo na leitura do maior representante do movimento simbolista:

\footnotetext{
Além disso, tendo começado a evoluir para mais definido espiritualismo, mais ainda inseguramente, em Faróis, só nos Últimos Sonetos ele apresenta uma feição nitidamente cristã, feição essa que sempre foi nossa, e que ora, como em toda parte depois da Guerra, melhor, outra vez, se vivifica na nova geração.

(...) e Cruz e Sousa é um precursor três vezes: precursor de sua raça, precursor de uma nova orientação no mundo do espírito, precursor de uma parte do Novo Continente, pois que só agora ela está querendo dizer ao que vem (ibidem, p. 143).
}

De uma forma exemplar, o trecho acima acaba por reunir o conjunto de formulações que busquei destrinchar sobre o último momento de apreensão do simbolismo por Nestor 
Vítor. Em sua perspectiva finalista, o "melhor da produção" do poeta Cruz e Sousa encontrarse-ia em seu último livro, o mais "espiritualista" e "nitidamente cristão" de todos.

Mais do que isso, a reação espiritualista que o simbolismo de Cruz e Sousa significou em literatura, retomando os termos do estudo Farias Brito, é vivificado a partir da Grande Guerra: o desmoronar das antigas crenças cientificistas e progressistas serviu para reabilitar o idealismo reacionário em uma parte dos homens de letras. Era isso o que Nestor Vítor podia confirmar ao observar os "novos combatentes do momento" como Jackson de Figueiredo e Tasso da Silveira. Entretanto, a senda aberta pelo determinismo naturalista na avaliação racista do poeta Cruz e Sousa mantinha-se, buscando se ligar aos "novos tempos", de reação espiritualista.

É o que se vê, por exemplo, no trecho quando Vítor afirma que o poeta é um "precursor da raça". Aliás, os três caminhos abertos supostamente por Cruz e Sousa enformam bem as matrizes ideológicas que existiam em nosso crítico nesses anos 20: o núcleo do determinismo naturalista (o "precursor da raça"); o espiritualismo difuso ("nova orientação no mundo do espírito"); e o nacionalismo mais ativo e autoritário (o "Novo Continente" que diz “para o que vem”).

Essas três matrizes combinam-se e respondem pela avaliação de Nestor Vítor em torno do simbolismo e da obra de Cruz e Sousa nesse último momento de sua produção crítica. Notadamente, esta avaliação opõe-se à sua visada do final do século XIX e parece indicar, como sustentei, a noção de que o julgamento estético passa a segundo plano e outros critérios, de fundo moral, acabam prevalecendo em suas análises.

Entretanto, como disse, a adoção de novos critérios não invalida ou nega completamente critérios anteriores. Demonstra apenas uma dinâmica mais rica da produção em torno do simbolismo brasileiro a partir de um de seus representantes, o crítico Nestor Vítor, mostrando uma visão mais complexa do que representou o movimento no período da República Velha. 


\section{NESTOR VÍTOR E O MODERNISMO BRASILEIRO}

\subsection{A apreensão do movimento modernista}

Como foi exigido a Nestor Vítor, no começo do século XX, que ele se abrisse a novos referenciais para que continuasse produzindo sua obra crítica, dado o enfraquecimento da estética simbolista; nos anos de 1920 ele também foi obrigado a se abrir às novas experiências artísticas que se apresentavam como importações culturais e que seriam conhecidas pela historiografia literária como "modernismo brasileiro" 115 , mas que figuram em seus textos, em geral, como "futurismo" e manifestações "futuristas".

Aliás, a denominação "movimento modernista" praticamente inexiste nos escritos de nosso crítico. O que refletia o desenvolvimento do próprio movimento que se definia, de modo que Nestor Vítor, no papel de observador, acabava apenas por utilizar os nomes e rótulos mais conhecidos.

O termo "futurismo" vulgarizou-se no final dos anos de 1910 no Brasil na imprensa carioca e, particularmente, paulista, conforme afirma Brito (1964) em Antecedentes da Semana de Arte Moderna. Além disso, a sua difusão esteve ligada, sobretudo, ao contexto da Guerra e ao próprio caráter propagandístico da nova "estética" que se materializava mais em vários manifestos e artigos de polêmica do que propriamente em obras de arte (TELES, 1977, p. 78-88).

Como aponta Wilson Martins, em A crítica literária no Brasil (volume I), as denominações de "futurista", "modernista" e, em seguida, "moderno" estiveram ligadas ao contexto de surgimento dos agrupamentos vanguardistas e à associação com os escritores que os utilizavam. Por isso, o estudioso afirma que, em 1924, por exemplo, “os modernistas começam a repelir, com insistência cada vez maior, o epíteto de 'futurista', também ligado a Graça Aranha pela compilação dos respectivos manifestos" (MARTINS, 1983, p. 504) e

115 Conforme afirma Stegagno-Picchio: "Desde que a denominação Modernismo penetrou como termo da crítica e da historiografia para designar uma precisa realidade literária (e artística em geral) brasileira, a palavra assumiu uma pluralidade de significados diversos e apenas parcialmente coincidentes. Conforme seja usada em acepção cronológica ou estilística, ou ainda quando, como na maioria dos casos, invoque as duas acepções, ela pode significar, lato sensu, todo o período literário que vai desde 1922 aos nossos dias, e que teve uma 'inauguração' oficial com a Semana de Arte Moderna, ocorrida em São Paulo de 11 a 18 de fevereiro de 1922; ou o conjunto de experiências estéticas, estilísticas, expressivas, 'culminadas' e oficializadas na Semana de Arte Moderna, como uma passagem da quantidade à qualidade, numa tomada de consciência de um processo há muito tempo em ação (e não pacífico fluir) de personagens e de gerações na direção da inteligência nacional” (STEGAGNO-PICCHIO, 1997, P. 463). 
referindo-se aos textos de 1925 afirma que "a verdade é que o próprio movimento, num processo inevitável e normal de maturação, estava sub-repticiamente passando do modernismo ao moderno, assim como já havia passado do Futurismo para o Modernismo" (ibidem, p. 513).

Com efeito, Nestor Vítor que recebia as "novidades" como um observador externo, já que, diferente do simbolismo do final do século XIX, ele não atuava como um representante das novas estéticas, aderia aos preconceitos e aos rótulos mais correntes. Sinal desse afastamento com o "futurismo" é o fato de que, por exemplo, em toda a sua obra coligida da década de 1920, exista apenas uma referência textual à expressão "Semana de Arte Moderna".

Em artigo de 1930, ao tratar do caráter um tanto deslocado, senão abertamente "passadista", de Graça Aranha após a Guerra, indica a ação do escritor junto aos "futuristas": "Voltou-se então resolutamente para os novos e foi fazer aquela conferência com que inaugurou a Semana de Arte Moderna, no Teatro Municipal de São Paulo" (OC, vol. II, p. 277).

Fora essa menção, não há outra nos textos reunidos em sua Obra Crítica. Não tanto porque Nestor Vítor não se ocuparia dos "futuristas" mas porque buscaria "amenizar", diria, a influência e o domínio daqueles que realizaram a Semana de Arte Moderna, filiando-se a um grupo divergente, com o qual ele já mantinha relações desde o final dos anos de 1910, a ala espiritualista do modernismo ${ }^{116}$.

A necessidade de Nestor Vítor tratar dos "futuristas" ocorreu, na verdade, por meio dos "novos" que ele lia como neossimbolistas ou de um espiritualismo difuso em fins dos anos de 1910, a exemplo de Menotti del Picchia, Tasso da Silveira ou Murilo Araújo, os quais, ao ingressarem na nova década, por suas experiências formais no verso, demandavam do crítico um olhar sobre as vanguardas europeias, e sobre o conjunto de influências dessa nova geração.

Em abril de 1917, por exemplo, Vítor escrevera sobre o livro de estreia de Murilo Araújo, Carrilhões, o qual ele filiou a uma espécie de "simbolismo ortodoxo" 117 e foi obrigado a volta a escrever sobre o poeta em 1922 para comentar o poema de pretensão épica

116 De acordo com Helena (2003), poder-se-ia pensar o movimento modernista a partir de, ao menos, quatro "tendências", manifestas em revistas editadas nos anos de 1920: a tendência universalista (revista Klaxon), a tendência primitivista (revistas Pau-brasil e Terra roxa), a tendência ufanista (revista Anta) e, finalmente, a tendência espiritualista (revista Festa). Conferir o livro Modernismo brasileiro e vanguarda (HELENA, 2003).

117 Ver "Carrilhões por Murilo Araújo" (OC, vol. II, p. 85-6). 
"Cidade de Ouro"118, que, além da influência simbolista apresenta novas características do momento que precisavam ser reconhecidas. Do mesmo modo, em maio de 1918, escrevera sobre o livro de poesia Fio d'Água de Tasso da Silveira e retorna a falar do escritor ao comentar o livro de crítica deste, A Igreja Silenciosa ${ }^{119}$, também em 1922, em um cenário que já havia aparecido a revista Klaxon.

Desse modo, ao acompanhar a carreira literária dos dois novos escritores, Murilo e Tasso, com os quais ele simpatizava e encontrava ecos das estéticas passadas, ele é obrigado a se referir explicitamente aos "futuristas". Nomeando-os, a partir de 1922, Nestor Vítor precisa buscar explicar a novíssima "estética" em nossas letras, explicar a "hora atual".

Na primeira aparição do termo "futurista", no texto sobre Murilo Araújo, de 30 de julho de 1922, o crítico aponta a crença que depositou no jovem poeta em 1917 e conclui no elogio ao seu grande "talento" que conseguia refletir o momento presente:

Como, entretanto, Carrilhões, foi uma linda, uma encantadora promessa, embora já no seu amaneirado e no seu nefelibatismo caraterizasse um epígono do simbolismo lusitano e brasileiro; este volume atual é a obra que mais vivamente condensa em nosso país, até aqui, o que seja a poesia lá fora nos tipos mais culminantes entre quantos influenciam mui sensivelmente a atormentada hora atual (...) (OC, vol. II, p. 215).

A "atormentada hora atual", entretanto, liga-se tanto ao canto da cidade moderna que Nestor Vítor via também em Walt Whitman ou Émile Verhaeren, como fontes positivas de influência para o poeta, quanto à estética das novas vanguardas, consideradas então como fontes negativas de sua arte.

\begin{abstract}
O que há de falho em teu risonho e ofuscante poema, caro Murilo, em parte se deve atribuir à idade em que ainda te achas, em parte aos defeitos ou às deficiências da estética atual. Os primeiros simbolistas, que pretenderam isolar-se aristocraticamente na 'Torre de Marfim', erraram por falta de contato verdadeiramente humano e produziram obra de estufa, que de pronto envelheceu. Os últimos, os que já confinam com os futuristas, envolvendo-se no grosseiro e tremendo tumulto do tempo, no antes da Guerra, na Guerra e no após a Guerra, forçosamente febricitantes, desordenados e desmedidos serão. Tu participas de uns e de outros. É natural que de uns e de outros tenhas os defeitos (ibidem, p. 229-30).
\end{abstract}

Além da crítica ao caráter "artificial" do simbolismo, que ficou corrente depois de 1914, Nestor Vítor avalia negativamente a "estética atual" que proviria do clima da Guerra.

118 Ver "A Cidade de Ouro por Murilo Araújo" (OC, vol. II, p. 213-30).

119 Respectivamente, "Fio d'Água por Tasso da Silveira" (OC, vol. II, p. 103-10) e "A Igreja Silenciosa por Tasso da Silveira" (OC, vol. II, p. 247-60). Como os artigos anteriores, todos reunidos em Cartas à Gente Nova, de 1924. 
Os "futuristas" aqui figuram como representantes do "tremendo tumulto do tempo", antes apresentada como "atormentada hora atual". Eles são vistos negativamente, o que, sem dúvida, refletia o impacto do elogio da guerra, "única higiene do mundo", que figurava no manifesto de Filippo Marinetti, já vulgarizado àquela hora ${ }^{120}$.

Desse modo, observa-se, nessa primeira aproximação com as vanguardas, de que o futurismo seria um representante, um olhar mais voltado ao contexto de produção das novas "estéticas" do que ao resultado inovador que estas poderiam provocar para as artes e a literatura em especial.

De fato, a referência feita rapidamente aos "futuristas" não é explicada, nem comentada. Os defeitos da poética de Murilo Araújo figuram mais pela associação que o escritor estabelece com o já considerado artificial simbolismo e com o contexto belicoso da Guerra encarnado pela referência à estética do "futurismo".

Entretanto, considerando o impacto das vanguardas e as promessas da nova década pós-Guerra, Nestor Vítor relativiza a sua crítica, apresentando a consciência de que o seu julgamento crítico possa ser passadista. Assim, nos parágrafos finais de seu artigo sobre a poesia de Murilo Araújo, afirma:

\begin{abstract}
Grande parte do que hoje se nos afigure excessivo na tua quente e complicada pintura, talvez que o futuro reconheça como uma antecipação divinatória da nossa arte propriamente dita, aquela que se imponha correspondente às nossas necessidades estéticas, incorporados de corpo e alma que então estaremos a este maravilhoso habitat (ibidem, p. 230).
\end{abstract}

Esse olhar "generoso" sobre os novos escritores que permite relativizar a própria visada crítica, baseada na crença de que os critérios presentes poderão ser abandonados no “futuro", é o que permite talvez a Alfredo Bosi ou a Otto Maria Carpeaux enxergar em Nestor Vítor a "simpatia" com as vanguardas modernistas.

Segundo Alfredo Bosi, em História concisa da literatura brasileira, a aproximação com o simbolismo e a própria abertura de uma crítica impressionista permitiu um olhar simpático de Vítor com as vanguardas: "O seu Simbolismo lúcido, dando as costas aos valores acadêmicos, pode aproximar-se com simpatia das vanguardas modernistas” (BOSI, 2006, p. 316). Ou ainda, conforme Otto Maria Carpeaux, em Pequena bibliografia crítica da literatura brasileira: "Nestor Vítor foi o crítico principal do movimento simbolista (...). Mais

120 Conferir os comentários de Gilberto Teles e os manifestos transcritos do futurismo em Vanguarda Europeia e Modernismo Brasileiro (TELES, 1977, p. 78-88) 
tarde demonstrou compreensão pelo modernismo, embora muitos o considerassem, injustamente, como 'démodé”" (CARPEAUX, 1967, p. 308).

No entanto, como aponta Silveira (2010), a "simpatia" ou a "compreensão" de Nestor Vítor não foi absoluta. Esteve dirigida a uma determinada ala do modernismo, a dos que seriam conhecidos como espiritualistas e remontariam, na visão retrospectiva do crítico, ao já morto simbolismo.

De fato, dos artigos presentes tanto em Cartas à Gente Nova quanto em Os de Hoje, verifica-se uma dominância de autores que formariam, por exemplo, a revista Festa, com exceção talvez de Mário de Andrade, que, além de figurar em um longo artigo no qual o crítico avalia os livros Clã do Jabuti e Macunaíma, também é citado em vários outros artigos como um homem de letras de boa formação, de talentosas "páginas civilizadas", e um dos "mestres" dos "futuristas".

Não obstante a restrição do crítico, a necessidade, como afirmei, de acompanhar a trajetória dos novos artistas em que ele apostava, no começo da década de 20, permitia um olhar mais indagador sobre a sua própria perspectiva crítica.

Na segunda referência ao termo "futurista" no ano de 1922, em artigo sobre Tasso da Silveira, Nestor Vítor revela uma "abertura” para a renovação nas artes:

\footnotetext{
Creio bem, a feição da literatura dos novos ainda se tornará mais eugênica, senão, como diria Nietzche, mais dionisíaca.

Os futuristas, cinemáticos e gritantes, por excelência, que ora se agruparam na Klaxon, de S. Paulo - essa revista absurda e simpática, - concorrerão afinal organicamente para isso?

Os Condenados, de Oswald de Andrade, pertencente ao grupo, é livro que representa um comprimido de admirável capacidade explosiva e por isso de originalíssimo processo artístico. Se ainda tem muito de cosmopolita, daquele cosmopolitismo elegante que caracterizou Paulo Barreto como escritor, já se encontra nele seriedade íntima e um interesse humano mais profundo, que amanhã poderão fazer deste jovem um grande romancista.

Estamos, com o mundo inteiro, numa volta da história. Amanhã podem vir acontecimentos que transfigurem os espíritos ainda em formação aqui (ibidem, p. 260).
}

Além disso, no final desse artigo sobre A Igreja Silenciosa, faz a afirmação que citei no capítulo anterior sobre viver "mais da vida que suscitei do que daquela que pessoalmente ainda represento nesse mundo" (ibidem, p. 260), o que evidencia tanto uma certa consciência sobre o seu papel no campo literário brasileiro quanto fornece pistas para explicar a sua aproximação "simpática" com as estéticas da nova geração, porque, como afirma, “(...) não preciso dizer-te que quanto maior tu fores mais em ti me glorificarei” (ibidem, p. 260). Ou 
seja, Nestor Vítor encara que seu "tempo", sua "hora", já passou e precisa se ligar a novos escritores que poderiam manter o seu legado.

Com efeito, ao observar o novo fluxo de escritores, o surgimento de novas estéticas, e as mudanças no gosto público, o crítico investe em alguns "novos" que, por afinidade intelectual, poderiam significar a continuidade de seu nome nas letras nacionais. Assim, tratar do "futurismo", mesmo que para avaliá-lo negativamente, era uma "demanda" imposta pelos novos artistas e pelos novos tempos, parte, portanto, do universo de possibilidades do espaço crítico do período.

Assim, o seu último livro, Os de hoje, publicado postumamente em 1938 mas que já vinha sendo organizado por ele próprio, reúne, em sua maioria, artigos que tratam de "figuras do movimento modernista brasileiro" (subtítulo do livro dado pelos editores da Editora Cultura Moderna). Sobre alguns dos artigos deste livro, tratarei na próxima seção.

\subsection{Alguns artigos de Os de hoje}

O texto que abre o livro é o já citado "Graça Aranha: Antes da Guerra/Depois da Guerra”. O comentário que havia traçado no segundo capítulo desta tese centrava-se na questão da política literária que cercava a produção do autor de Canaã no período anterior à Guerra. A segunda parte do artigo, "Depois da Guerra", também acaba relacionando o escritor com as disputas por consagração no campo literário, mas o faz associando-o com os novos atores dessas disputas, os vanguardistas de São Paulo.

Se o 'futurismo' já tinha, sem pedir licença a Graça Aranha, feito suas primeiras esturdices em São Paulo, com programa próprio, o apoio caloroso que ora recebia do celebrado autor de Canaã, ministro, acadêmico, e, além disso, vindo como vinha cheio de elogios que lhe fizeram em Paris, deu-lhe gaz para explodir como explodiu. Eles procediam do dadaísmo, que em seu início fizera tácita simbiose com a fúria destruidora dos maximalistas na Rússia. Eram iconoclastas por natureza. Haviam de rir à socapa do velho ingênuo que lhes vinha dar a mão. (...)

Depois foi o que se viu. Despedindo-se da Academia, de cujos pingues jetons nobremente desdenhou, era, não tardava muito, deposto da chefia dos 'futuristas' por Mário de Andrade, com aquela irreverência, para não dizer aquele desbragamento tão da ética vinda com a hora atual (OC, vol. II, p. 277).

A perspectiva de Nestor Vítor sobre a vida literária talvez revele sobremaneira o que Wilson Martins já afirmara sobre o nosso crítico: "uma certa concepção paroquial ou grupal da vida literária" (MARTINS, 1983, p. 333), porquanto fica evidente o modo como Vítor 
busca enquadrar os escritores a certos compromissos com os grupos a que eles "naturalmente" seriam destinados.

$\mathrm{Na}$ visão de Vítor, Graça Aranha, embora tenha bebido na estética simbolista, afeiçoou-se aos naturalistas da Academia, o que já fora um "pecado" em seu passado e, agora, chegado aos anos 20, buscava ligar-se a escritores que eram "iconoclastas por natureza". Em outras palavras, Aranha não revelava o respeito ao espírito "grupal” que parecia ser inerente à vida intelectual. Ao menos, esse sentimento parece ter marcado as experiências de Nestor Vítor e ele projetava tal sentimento sobre os demais homens de letras do período. Em função dessa percepção, ele acaba por aplicar uma censura a Graça Aranha que se afigura como moral: "o velho ingênuo" que busca se entrosar com aqueles que provinham dos "dadaístas".

Além disso, nesse texto, que já é do final de sua carreira (1930), mais uma vez, há uma referência negativa às vanguardas sem que se justifique a razão dessa crítica. Ou até há, mas não por algum motivo "literário" ou "estético", mas pelo fato de que os "moços" vanguardistas, tendo à frente Mário de Andrade, que é citado no artigo, não tiveram a necessária “cortesia” com Graça Aranha: "Os acadêmicos que já escreveram sobre o livro $[A$ Estética da Vida], isto é, aqueles que Graça abandonou pelos moços, tiveram, com maldade glacée ou por política, seja como for, mais cortesia com ele" (ibidem, p. 278).

Dessa perspectiva, o olhar crítico de Nestor Vítor sobre as vanguardas e o modernismo é filtrado, como afirmei, pelas disputas do passado. Em outro artigo de Os de hoje, já citado, sobre Raul de Leoni, há aquela afirmação de que o "vanguardismo, porém, entre nós, ou vem do simbolismo ou vem dos parnasianos". Isto é, Vítor mantinha como critério de avaliação da arte literária a oposição entre literatura "objetivista" e literatura "subjetivista": os que cantavam o ritmo da vida moderna, a exemplo de Mário de Andrade ou Guilherme de Almeida da revista Klaxon provinham da tendência objetivista (antes associada ao parnasianismo/naturalismo); os que mantinham um olhar sobre a vida interior, a exemplo de Murilo Araújo ou Tasso da Silveira representariam a tendência subjetivista (ligada à corrente “místico-simbolista” do passado).

Percebe o crítico, contudo, que o momento atual parecia favorecer mais à tendência objetivista e "iconoclasta por natureza": "Nunca apareceu tanta gente nova em todos os campos da atividade e nunca mudaram tão rapidamente as tendências. É como se a guerra houvesse levado tudo o que era, e chegassem, não se sabe de onde, novos ocupantes, e cujos olhos o que estava é como se nunca tivesse estado, o que foi como se não fosse" (OC, vol. II, 
p. 295), como escreve em outro artigo de 1928, sobre Tasso da Silveira, lamentando, em parte, a efervescência dos anos 20 .

Neste artigo, intitulado "Inquietação", a propósito do livro de Tasso Alegorias do Homem Novo, Nestor Vítor faz referências a algumas vanguardas europeias e busca relacionálas ao contexto histórico. Segundo o crítico, a teoria cubista, por exemplo, está intimamente associado ao contexto de horror da Guerra:

O fato de todo o Paris que se preocupa com arte ter-se acalorado na discussão da extravagante teoria cubista, ainda em plena guerra, veio demonstrar, indiretamente, $\mathrm{o}$ seu horror a esta. Esse horror traduzia um sentimento geral, inspirado pela convicção íntima de que o capitalismo - consequência do individualismo - é que trouxera a conflagração, subalternizando as instituições e os princípios à sua voracidade implacável (ibidem, vol. II, p. 296).

Com efeito, parece correto a Nestor Vítor avaliar que o mundo pós-Guerra viria abalar os alicerces da arte, como de fato ocorreu. A "ingenuidade" dos novos tempos é buscar romper em absoluto com o passado sem oferecer algo de "vulto", apoiando-se mais em propaganda do que propriamente em obras de valor.

De qualquer modo, nada mais lógico: as letras tinham de traduzir, por força, mormente a poesia, tal estado d'alma.

Guerra ao que foi, principiando pelo verso. Verso novo, ritmo novo e, para os falsos poetas, nada de verso, até nada de ritmo propriamente dito. É pouco: mesmo na poesia, tudo, mas poesia não. (...)

O futurismo, o cubismo, o dadaísmo, o expressivismo, o supra-realismo ainda não deram e parece que não podem dar um grande vulto. O que eles produzem de mais considerável é programas (ibidem, p. 296-7).

A conclusão desse diagnóstico é, de modo geral, negativo. O crítico não consegue enxergar poesia na dissolução total do verso ou do ritmo, nem supor que as vanguardas têm potencialidade além de seus proclamas. Não obstante, para além do que já realizou, o movimento vanguardista é visto também de forma "simpática", pela promessa que representam os "moços", uma nova gente que:

vem ardorosa, confiante em que lhes foi dado viver uma hora como ainda não houve maior. E vem cheia de uma seiva espiritual que se tem manifestado, sobretudo, pelo bom humor. É certo, com isso, muita instabilidade ainda (...) Mas nada ou quase nada de amargurado negativismo, de pessimismo paralisador (ibidem, p. 297).

Essa fé nos "moços", aqui manifesta nos elogios a Tasso da Silveira, aparentemente oposta à descrença nas novas vanguardas, reflete também a necessidade de vincular as 
estéticas do passado com as propostas do presente, numa solução de continuidade e não de completa ruptura, como apregoavam algumas das vanguardas europeias.

Parece-me que Vítor buscava, a partir desse movimento dicotômico, elogio e crítica, guiar os novos escritores para assim aparar os "excessos" que ele considerava nocivos à sua concepção de arte, de literatura, de poesia. Essa postura fica evidente ao tratar especificamente do verso nos últimos livros de Tasso. Demonstra que sua concepção de poema ainda é aquela dos nossos poetas simbolistas e também parnasianos do final do século XIX e começo do XX.

\footnotetext{
Sim, porque a diferença que vai entre os simbolistas propriamente ditos e os que se lhe seguiram imediatamente, entre os quais o nosso poeta figura com este livro, ainda em 1924, é que os primeiros cantavam, de fato, e os últimos são de um verso mais surdo, quando não seja menos verso. É que até na poesia eles querem, sobretudo, ser conceituosos, de modo que, trabalhando embora com suprema elegância, arriscam-se a não representar mais do que uma intenção poética. Revelam-se predominantemente pensadores, críticos, por mais poetas que sejam alguns. (...)

Os chamados ritmos espontâneos são correspondentes ao agudo intelectualismo do instante atual. Só eles, de regra, podem favorecer a poesia presente, que ainda tanto se confunde com a prosa, como a prosa se confunde com ela. É um estado caótico, algo decadência, algo juvenilidade (ibidem, p. 299).
}

Como se vê, há uma ligação com o passado, o modelo dos simbolistas, e a realização dos novos escritores. Uma realização que traz em seu bojo uma intenção gorada aos olhos do crítico. O verso deve "cantar" e não ser "surdo"; ser "poesia" e não "prosa".

Paradoxalmente, como percebe o crítico, é essa intenção gorada, materializada nos "ritmos espontâneos", que reflete melhor o "instante atual”. É como se Nestor Vítor julgasse irresistível as novas estéticas surgidas com as vanguardas europeias, mas buscasse limitar o seu alcance, em um jogo de elogio e crítica alternados para apontar o caminho para os que estavam sob a sua influência, os escritores que o acompanhavam desde o final dos anos de 1910, como Murilo Araújo, Tasso da Silveira ou Gilka Machado.

De igual maneira, a atitude "simpática", mas desconfiada de Vítor, deveria nascer também dos valores combatentes de outrora quando se opunha ao mundanismo burguês e à oficialidade da Academia. Por isso, nesse mesmo artigo dirigido a Tasso, pôde também escrever linhas bastante elogiosas aos "futuristas" em relação à postura intelectual que mantinham diante do meio cultural.

De passagem: não tem sido inútil o "futurismo" no Brasil. Quantos o representam, sem ser por apenas acompanhar, vivem naquele arrebatamento desinteressado que 
caracteriza todos os intelectuais capazes de realmente criar alguma cousa. Tenham que defeitos tiverem e sejam quais forem seus erros em arte, há neles um pugilo de estudiosos, de experimentadores inquietos, à altura, por este lado, do instante em que lhes coube ser moços. É natural, assim, que concorram para estimular ao menos seus companheiros de geração, para aquecer e movimentar o meio, embora com resultados diversos, talvez, daqueles que esperavam colher. Além disso, são incontestavelmente uns sacrificados, porque, quanto mais ortodoxos, mais fazem apenas a gente rir. Outro serviço, aliás, nos tempos de bochorno que vamos atravessando... (ibidem, p. 303).

Como se vê, podemos observar aí ecos daqueles elogios aos combatentes do passado, os nefelibatas, que também faziam rir e que apresentavam o "arrebatamento desinteressado"; marcas sociais assumidas positivamente pelo crítico no final do século XIX.

Seria bom lembrar aqui a tese de Antonio Candido em torno da relação entre os modernistas e os remanescentes do simbolismo. Para Candido, embora o Modernismo tenha sido uma ruptura mais profunda com as estéticas do passado, incluindo aí o simbolismo, teve, em sua primeira hora, como combatentes ao academicismo os remanescentes desse movimento. Na esfera das disputas no meio cultural, os "futuristas" e os epígonos do simbolismo faziam uma frente contra o domínio de naturalista e parnasianos ${ }^{121}$.

Tal interpretação feita por Candido deve ter surgido também como uma percepção sutil para Nestor Vítor, de maneira que este pôde fazer o elogio da postura combatente em relação ao meio dos novos escritores, sejam os "futuristas" ou os espiritualistas, embora a estes é que eram reservados os maiores elogios:

O modo como o próprio Rio vem recebendo este livro [Alegorias do Novo Homem, de Tasso, publicado em 1926], com invulgares e propagados aplausos, é um bom sinal.

É sinal de que há mais latitude do que se pensa em nosso meio, apesar desta torva hora. De que há entre nós, na própria nova geração, quem dê valor, e o justo valor, ao que em arte não é mundano, nem prima sequer por exterioridades que aturdem. Vê-se, ainda há lugar para os que vivem sobretudo de vida interior (...) (ibidem, p. 304)

Percebe-se, com esses trechos e ao longo do artigo sobre Tasso da Silveira, de 1928, como Nestor Vítor busca integrar o passado com a "hora atual", selecionando aquilo que lhe agrada e deve permanecer com aquilo que é visto como "excesso", "instabilidade"; "defeito",

121 A tese de Candido poderia ser resumida, grosso modo, nas seguintes palavras: o Modernismo encontrou duas "tendências estéticas": "o idealismo simbolista e o Naturalismo convencional. Aquele dissolvendo-se no penumbrismo vers-libriste; este no diletantismo acadêmico". Mas o "Modernismo rompe com as duas tendências, mas sobretudo esta, que ataca com a cooperação assustada dos espiritualistas (...). Deixa de lado a corrente literária estabelecida, que continua a fluir; mas retoma certos temas que ela e o Espiritualismo simbolista haviam deixado no ar" (CANDIDO, 2006 p. 124-5). 
em suma. Busca, com isso, avaliar as novas produções com base nos critérios que já estabelecera nos anos anteriores de sua produção crítica.

Assim, ele termina o artigo afirmando que os escritores devem encontrar "a alma do Brasil”, mas não qualquer Brasil, pois não devem "exaltar” um Brasil "ainda tartamudo e feio, até o último céu, porque é o nosso Brasil, ou rindo-se dele", adaptando-se assim "às misérias do tempo, antecipadamente descrentes de quaisquer outras realidades superiores" (ibidem, p. 304-305). Isto é, o nacionalismo da nova geração deveria ser aquele que ele própria defendia e que já havia expresso antes.

Como visto no capítulo anterior, há um ideal de Brasil que Nestor Vítor quer alimentar: de um Brasil que caminhe para a civilização sem fazer o elogio do que seria "feio", como o sertanejo embrutecido de Monteiro Lobato ou o primitivismo exagerado de Menotti del Picchia em Juca-Mulato ${ }^{122}$.

Desse modo, o que se verifica de sua crítica em torno da nova arte, a futurista/modernista, é que a sua aceitação é feita com reservas, ressalvas. As restrições que defende buscam responder aos critérios que ele adotara a partir da Guerra: o vínculo com as "tendências subjetivistas" (tradição romântica e simbolista), lidas então como reação espiritualista, e a adesão a certo moralismo nacional, que surge no contexto da Primeira Guerra Mundial.

Em outros artigos de 1928, também sobre Tasso da Silveira, Nestor Vítor deixa mais nítidas as suas escolhas, bem como o modo como percebe a recepção das vanguardas por nossos modernistas e as divisões no interior do novo movimento. É o que parece no artigo "Um líder do vanguardismo", de 24 de outubro. Vejamos alguns trechos.

\footnotetext{
Mas, retirando-se os olhos da passada gente do símbolo e olhando-se para os outros vanguardistas atuais do Brasil, sobretudo esses que Mário de Andrade chefia, não se torna evidente que Tasso da Silveira, pelo que acabo de citar, acha-se em princípios pelo menos ombro a ombro com eles? Não são estes, nos seus propósitos conscientes da mais radical oposição ao fantasioso romântico? Não aceitam, até babando-se de gozo, até pedindo pior, muito pior, a selvageria mal disfarçada deste nosso pobre e querido Brasil? (OC, vol. II, p. 307).
}

122 O comentário ao "sertanejo" em Monteiro Lobato já foi feito no capítulo anterior; para Vítor, Monteiro Lobato, com Jeca Tatu, cria uma imagem caricatural do nosso "homem do interior" que nos levaria à paralisia moral. Quanto ao Juca-Mulato, Nestor Vítor publicara, em 1918, um breve carta elogiando os versos do poeta, de um "brasileirismo realista e idealista, a um tempo, com tintas do misticismo atual", mas restringindo o elogio ao criticar a "falta" de um "gosto seguro, que se acorde com o gosto geral, principiando pelo título" (OC, vol. II, p. 90), o que faz depreender certa repulsa do crítico pelas expressões ou tipos "vulgares", cujo caráter pouco "elevado" fugiria das idealizações que ele considerava importantes na representação do tipo nacional. 
Como se nota, Vítor mistura a ideia de que já existe uma divisão na nova geração de escritores (de um lado, Mário; de outro, Tasso) e um julgamento negativo do modo pelo qual o Brasil seria retratado pelos "andradistas". O objetivo de Nestor Vítor, nesse momento, é reforçar o polo de Tasso da Silveira, rejeitando a visão nacional surgida a partir dos "futuristas", que queriam "a selvageria mal disfarçada deste nosso pobre e querido Brasil".

Todavia, o crítico, para o seu propósito, não rechaça simplesmente a literatura que ele supõe de inspiração "dadaísta". Ele busca explicá-la "sociologicamente", isto é, relacionandoa mais uma vez com o clima da guerra e até da revolução russa, que teriam provocado o surgimento dessas estéticas passageiras.

Não houve no Brasil, nem de longe, os mesmos motivos que na Europa, com a guerra e com a revolução russa, para o surto daquele pessimismo dionisíaco que foi o dadaísmo. Ele veio convulso, querendo tudo arrasar, com fundo nitidamente bolchevista.

(...)

Por que não importaríamos igualmente o dadaísmo... nem que fosse de pândega? Que mal que se troçasse aqui colossalmente dos valores consagrados como por lá pela Europa se fez? Eles já tinham gozado da glória seu pedaço... Place aux jeunes, como todas as gerações vêm gritando. Troça contra os "medalhões" e contra a própria arte, contra as melhores realizações desses idealistas, que viveram no mundo da lua (ibidem, p. 307-8).

O raciocínio parece semelhante ao que já usara contra os naturalistas: uma moda passageira e nada correspondente à nossa realidade nacional aparece aqui e quer fazer "escândalo", aproveitando-se do clima de "pândega", de troça, já implantado na Europa.

Além disso, o crítico estabelece um paralelo, já citado: o fato de os "andradistas", os "futuristas", supostamente provirem dos parnasianos:

O contágio dos dadaístas europeus levantou um fogacho real nas almas dos nossos jovens poetas necessitados de rumor ou ao menos de tonteira, vários dos quais viram o beco sem saída em que se haviam metido nos seus primeiros ensaios de epígonos parnasianos (ibidem, p. 308).

De modo efetivo, a leitura de Nestor Vítor, para quem a critica deve ser voluntariamente imparcial, tinge-se de espírito de coterie novamente. Os excessos, os "escândalos", necessariamente viriam das correntes que foram adversárias do simbolismo e agora dos espiritualistas. O "futurismo" dos paulistas seria contraposto ao vanguardismo "sadio" que se irradiava da ala espiritualista. 
A essa obra de puras ideias, como a do vanguardismo literário, posterior à epilepsia dadaísta, Tasso da Silveira e outros, seus amigos, seus irmãos, aqui no Brasil, corresponderam e vão correspondendo decididos e com o mesmo entusiasmo.

Distantes como estamos, felizmente, da atmosfera europeia, eles desde logo denunciaram a artificialidade do nosso mal denominado 'futurismo', inserindo-se na hora, entretanto, com a oportunidade para que naturalmente seu espírito, seu instinto os levaram. Foram eles até que primeiro lançaram as bases do programa, hoje comum, na essência, a toda a nossa nova geração.

A América Latina, primeiro, agora Festa, revistas de pensamento e de arte, e as obras que Tasso como os outros vêm publicando, o atestam (ibidem, p. 309).

A evolução da literatura das últimas décadas está traçada nessa perspectiva de Nestor Vítor: o vanguardismo encontrou sua expressão mais "natural" no grupo dos espiritualistas que, desde o final dos anos de $1910^{123}$, teriam lançado o "programa" de "toda a nossa nova geração". Dessa "evolução", surge a liderança de Tasso da Silveira e o próprio vanguardismo desses "aparentes reacionários", que "de fato antes de terem que reagir dentro de sua geração já vinham criando a nova hora com representá-la de um modo vivo e significativo" (ibidem, p. 309).

Por conseguinte, é a ala espiritualista de modernismo que representa o vanguardismo que se alia à tradição nacional, na visão de nosso crítico. Os “futuristas" de São Paulo apenas representam uma descontinuidade, que reflete o movimento estrangeiro:

\footnotetext{
Assim não se produziu uma solução de continuidade em nossa cultura. O dadaísmo representava esse hiato lá na Europa. Os 'futuristas' de S. Paulo, fazendo-se recentemente 'antropófagos', honram-se, ora mais do que antes, de promoverem um recuo até os caetés do tempo da descoberta. É engraçado, mas em todo caso mostra que o dadaísmo, ao menos como pilhéria, entre nós resiste vivaz.

Enquanto isso, já estão chamando de tradicionalistas dinâmicos a esses outros que do simbolismo se originam (ibidem, p. 309).
}

Por essa perspectiva, os "futuristas" paulistas aparecem como uma excrescência em nosso meio literário e lembram uma tradição não civilizada ("a dos caetés do tempo da descoberta") que foi soterrada, portanto, que não encontrou "continuidade" com a nossa cultura.

O que o nosso crítico obscurece em sua análise é que o próprio simbolismo foi lido também como uma excrescência em seu momento de surgimento. A não correspondência com o solo nativo, o não resultado de um produto da realidade social foi a crítica que mais pesou

123 Em uma sequência, poder-se-ia pensar que houve em 1917 o lançamento do livro de Murilo Araújo, Carrilhões, com a adoção do verso livre e em 1919 a fundação da revista América Latina (publicada entre julho de 1919 e fevereiro de 1920), citada no trecho acima, sobre a qual "sabe-se, por exemplo, que Nestor Vítor, então designado o 'Rodó brasileiro', aparece como um dos fundadores, ao lado dos 'novos' Tasso da Silveira, Andrade Muricy, Jackson de Figueiredo, Gilka Machado e Ribeiro Couto (...)" (BRAGA-PINTO, 2010, p. 47) 
na recepção da obra de Cruz e Sousa e que se difundiu na pena de José Veríssimo, como já comentado no capítulo anterior. De modo que a suposta tradição para o vanguardismo da década de 20 da ala espiritualista é forjada sob a base do esquecimento do que ocorrera há 30 anos e com base em um exagerado argumento sobre o artificialismo e estrangeirismo dos "futuristas", algo que negava efetivamente a proposta difundida pelos "andradistas" 124.

Ainda reforçando essa diferença entre o "futurismo" dos paulistas e a "arte" dos vanguardistas liderados por Tasso da Silveira, Nestor Vítor retorna à visão essencialista sobre a poesia, seu caráter necessariamente "sério". Liga-o, em seguida, à crítica que fora no passado dirigida ao simbolismo: o seu caráter nefelibata, solto "no ar".

\begin{abstract}
A arte mais barulhenta deste instante é singular, porém, no seguinte: (...) quanto mais $(\ldots)$ proclama ser a negação de si própria, porque recusa tomar-se a sério, menos por esse instante se faz entender.

Nunca se viu, até, arte que tenha funcionado tão no ar, tão sem entrosar-se com o momento para que é feita. Falo desse "futurismo" nosso, que resultou do dadaísmo europeu e também me refiro ao vanguardismo de lá que a esse daqui se prende por alguns dos seus aspectos (ibidem, p. 312).
\end{abstract}

A indisfarçável parcialidade de sua crítica nesse momento conflui para o critério de nacionalidade já exposto antes: Tasso da Silveira, tanto em Alegorias do Homem Novo, de 1926, quanto em As imagens acesas, de 1928, representaria um tipo de poeta que consegue falar "para o Brasil": "Como já em Alegorias vem aqui toda uma série de poemas bem humildemente escritos parece que só para nós do Brasil, e particularmente para quem se comove logo aos primeiros versos, sentindo o aroma fragrante da atmosfera (...)" (ibidem, p. 316).

Os artigos sobre Tasso da Silveira, assim como sobre Gilka Machado ou Murilo Araújo, reunidos em Os de hoje, evidenciam as escolhas de Nestor Vítor diante das tendências do movimento modernista brasileiro. Quando pôde demonstrar compreensão "generosa" com a nova geração, essa se revelou fruto de uma conjunção com as suas próprias idealizações em torno da arte e da literatura brasileiras. Quando, ao contrário, demonstrou ser abertamente "passadista", esteve afirmando os critérios de sua crítica que, como afirmei, mais ou menos se cristalizaram a partir da Grande Guerra e que permaneceram até o fim de sua vida.

Para observar essas duas perspectivas ("compreensivo" e "passadista") a partir da observação de escritores não alinhados à tendência espiritualista, comentarei na próxima

124 Conferir os conhecidos manifestos escritos por Oswald de Andrade: o "Manifesto Antropófago" e o "Manifesto da poesia pau-brasil" em Vanguarda europeia e modernismo brasileiro: apresentação e crítica dos principais manifestos vanguardistas (Teles, 1977). 
seção um texto sobre Mário de Andrade e um breve artigo sobre o centenário de José de Alencar, ambos reunidos na obra Os de hoje.

\section{3 "Futuristas" e espiritualistas: a aposta de Vitor}

O texto sobre Mário de Andrade é de outubro de 1928 e divide-se entre uma breve apresentação do escritor, um comentário sobre Clã do Jabuti (1927) e uma análise um pouco mais detida sobre Macunaíma (1928).

Verifica-se, de início, que Nestor Vítor tem a consciência de que se detém sobre um dos intelectuais mais bem formados da nova geração. Explicita isso ao elencar as qualidades do escritor, que seria um "dos pais" do "futurismo", crítico musical como poucos, um "escritor feito" que se diferencia da "récua enorme, como nunca houve, de pretendentes às letras", sendo, dentro dos vanguardistas, "a figura mais em foco no instante" (OC, vol. II, p. 352-3).

Vítor elogia também a irreverência de Mário de Andrade que "bateu" em Alberto de Oliveira e em Graça Aranha e que "bate os velhos porque entende que deve bater. Está no seu programa. Mas nada faz por inveja, por inconfessável despeito. Nem faz por incultura" (ibidem, p. 353). Identifica em Mário um combatente e um "mestre" da nova geração que demonstra ter independência e que busca os que têm valor ${ }^{125}$.

Nesse sentido, chega ao final da apresentação de Mário reunindo-o aos outros escritores da nova geração que ele mais considerava no momento:

\footnotetext{
O modo de ser de um Mário de Andrade, a sinceridade de intenções por parte de um Tristão de Ataíde, o ardor apostólico de um Tasso da Silveira, quando bate como quando louva, o fundo amor da cultura e larga compreensão do papel do crítico, que revela Andrade Murici, são tais e outros sintomas que me dão esperança de organizar-se, afinal, no que respeito à literatura, outro Brasil (ibidem, p. 355).
}

Após a apresentação, eivada de elogios, entra-se no comentário ao livro Clã do Jabuti quando se verifica que, em sua linguagem, em seus versos, em suas construções, os poemas do livro desagradavam ao crítico, contrariando aparentemente todo o esforço laudatório da introdução do artigo.

125 Percepção de Vítor que toda historiografia literária ao longo do século XX acabou por confirmar. Como indicou Stegagno-Picchio, Mário de Andrade foi a "consciência do Modernismo": o "teórico" e "um dos críticos mais sagazes do movimento" (STEGAGNO-PICCHIO, 1997, p. 489). 
O desagrado do Vítor começa pelo título da obra, que é criticado, porque o "título é uma novidade, a meu ver, de mau gosto. De mau gosto antes de tudo porque é 'difícil'" (ibidem, p. 356). Para o crítico, o hermetismo do título não cria um símbolo que seja facilmente reconhecível, "vulgar", como afirma. Vê-se que a preocupação é com a recepção da obra a partir do título e não com as intenções do artista ao produzi-la: "Como o nome, é quase todo [difícil] este livro de Mário de Andrade" (ibidem, p. 356).

Realizando uma análise "interna" do livro, associa os defeitos às vanguardas europeias:

\begin{abstract}
Versos que absolutamente não parecem versos, porque de música não têm nem tiquinho, na sua grande parte. Uma falta de virgulação quase que total, como quiseram impor os dadás. E que linguagem! Língua de caboclo tão cerrada como nunca a terá podido ouvir, muito menos apreender, quem pela roça não se criou ou não andou demoradamente, ouvidos alerta. Isto para expressar ideias e sentimentos, em geral, que por cabeça de caipira nunca puderam passar. Parece um tour de force diametralmente antagônico ao que representam as Sextilhas de Frei Antão. Um escangalhar de português que poucos brasileiros cultos podem conseguir. É uma nova espécie de erudição criada pelos "futuristas" agora. Tal qual andar-se ao par dos candomblés e sua indumentária, mais dos canjerês africanos, cousa que está igualmente em moda. Além disso, 'Carnaval Carioca' e 'Noite de Belo Horizonte', os trabalhos mais longos do livro, são construídos um tanto como aquele Losango Cáqui, também de Mário de Andrade, com muita elipse de pensamento, um tanto pelo processo dos supra-realistas. É preciso lerem-se e relerem-se trechos e trechos desses chamados poemas, e ainda assim de não poucas cousas o sentido nos escapa (ibidem, p. 356).
\end{abstract}

Como se vê, Nestor Vítor rejeita todas as inovações que a poesia de Mário de Andrade em Clã do Jabuti busca consolidar. Conforme indica Stegagno-Picchio, os livros Losango cáqui (1926) e Clã do Jabuti "desfrutam de todas as virtualidades do verso livre" e "também transportam para a poesia a linguagem popular, a língua quotidiana, os modismos locais que, de um lado, é o modo de Mário de aderir estilisticamente à cruzada nacionalista apregoada, em termos de destruição ou de reconquista, pelos modernistas de toda cor, e, de outro, de abordar o seu experimento de "invenção de uma língua brasileira"” (STEGAGNOPICCHIO, 1997, p. 487-8).

Entretanto, se Nestor Vítor não pode ver as "virtualidades" nem o "experimento" que puderam ser lidos posteriormente pela crítica literária brasileira, soube sim fazer o elogio da adesão de Mário "à cruzada nacionalista”, porque esta convergia com seus critérios de valor nessa sua etapa crítica.

Agora, fazendo-se abstração de tudo isso (...) 
O livro é um lindo espetáculo intelectual, porque, antes de tudo, mantém-se em tais páginas um gostoso euforismo, de princípio a fim, e grande agudeza de espírito.

(...) É estranhamente brasileiro, brasileiro moreno, no seu ar, nos seus meneios, nos seus quês, irmão do carioca como do paulista, do matuto de Minas, como do tirador de borracha do Acre. Intimamente identificado com as nossas águas, as nossas árvores, o nosso chão, conhecendo tudo pelo miúdo, e tal qual a gente simples conhece, sem nenhuma nomenclatura latina (ibidem, p. 356).

A audácia de Mário de Andrade, com seus "lindos termos brasileiros e boleios de frase" lembra a Vítor a capacidade criativa de um autor romântico por ele já tão festejado, José de Alencar: "Ter-se o gênio de um Alencar, aquele tato maravilhoso com que ele recamava a linguagem de brasileirismos que não repugnam, e sobretudo aquela música, tão nossa, mas antes dele unicamente aprendida na fala patrícia, é cousa rara” (ibidem, p. 357).

A aproximação entre o "futurista" Mário de Andrade e o consagrado escritor romântico não é, contudo, apenas devaneio de um crítico que, em sua fase final de produção, retomara a tradição romântica como a mais "legítima" em nossas letras.

$\mathrm{Na}$ verdade, o romantismo é retomado porque o nacionalismo ressurge com força no período da Grande Guerra e, de alguma forma, os "vanguardistas" da nova geração buscam responder a ele, sobretudo nesse momento em que se aproximam já da década de 1930.

Segundo Oliveira (2002), é a partir de meados dos anos 20 que a questão do "nacionalismo" torna-se mais presente na reflexão e na arte dos modernistas, em suas diferentes vertentes ou tendências.

\begin{abstract}
A partir de meados dos anos 20, o interesse dos protagonistas do Modernismo deslocou-se para a realidade interna nacional. A questão do nacionalismo (apenas literário no início, depois cultural, em latu senso) transformou-se em eixo central das reflexões. As revistas publicadas depois de Klaxon, de várias linhas e tendências, como Estética (1925), A Revista (1925), Terra Rosa e Outras Terras (1926), Verde (1927) e Revista da Antropofagia (1928), compartilham essa diferente orientação e o diverso clima espiritual dos vários grupos. O esteticismo exasperado da Semana de Arte Moderna é substituído pela preocupação de reintegrar a literatura na realidade, de mergulhar profundamente naquele Brasil do qual tanto se falava, mas que pouco se conhecia (OLIVEIRA, 2002, p. 66).
\end{abstract}

O elogio geral à obra de Mário de Andrade, apesar de todos os supostos defeitos de linguagem, da forma poética, ganham sentido nessa convergência de interesses em responder à questão de "descoberta do Brasil", de encontrar a verdadeira "música nacional", permitindo, assim, a Nestor Vítor "simpatizar" com o líder dos "futuristas".

Não é à toa que Vítor transcreva, no final dessa parte do artigo, todo o poema “Acalanto do Seringueiro", porque este poema reúne várias qualidades que o seu julgamento 
crítico valoriza: "parece-me que é o mais capaz de ser compreendido e admirado pelo geral dos leitores. Aí há música como no geral do livro não há, há clareza, simplicidade e sentimento, tais quais nos verdadeiros poetas se encontram (...)" (OC, vol. II, p. 357).

Vê-se, mais uma vez, que não são esses os critérios que balizaram a sua crítica no final do século XIX. A tradição e, em especial, a tradição romântica que dialogue com o que se considera cultura nacional é o que aparece em primeiro plano nessa apreensão da arte modernista já no final de sua produção crítica, em 1928.

$\mathrm{Na}$ última parte do texto, o crítico utiliza algumas páginas para tratar do então recentíssimo livro de Mário de Andrade, Macunaíma.

Começa a sua avaliação discorrendo sobre como pensadores viram o "índio da América". Indica que uma visão idealizada, "fantasista", passou para a literatura a partir de Chateaubriand (1768-1848), dando origem ao “indianismo, que o nosso Basílio da Gama já pressentira no século XVIII” (ibidem, p. 360). A realidade dos índios não é a idealizada, porque hoje ele é um "pobre vencido, descrido, muitas vezes reduzido a um bicho abjeto" (ibidem, p. 361). No entanto, a visão idealizada já tendo penetrado na literatura, permitiu a um escritor como José de Alencar exprimir uma linguagem que seria, a partir de então, a mais genuinamente nacional. O indianismo, logo, na perspectiva de Vítor, serviu à linguagem nacional, ao patriotismo em nossas terras.

Os naturalistas não puderam ou não souberam explorar a vertente indianista, prova, talvez, segundo Vítor, de seus deficientes "recursos estéticos". Os "futuristas" de São Paulo retomavam a veia "indianista", mas o faziam de um "modo humorístico": "resolveram fazer a propaganda da antropofagia numa revistinha cujo título já é um franco programa em tal sentido" (ibidem, p. 362). Nesse quadro é que surge a obra de Mário de Andrade.

\footnotetext{
Creio que vão ficar históricas essas páginas [as de Macunaíma]. Elas representam o início do neo-indianismo entre nós, como um livro pode representá-lo.

Antes de tudo, uma cousa Mário de Andrade consegue com esta obra: é torna possível que se façam outra vez enredos em que os personagens sejam bugres. Realizou, portanto, o que os naturalistas tinham dado por impossível (ibidem, p. 363)
}

Até aqui o que poderia parecer uma descrição de fatos da história: a visão sobre o índio entre os pensadores europeus, o seu ingresso na literatura, o não tratamento do tema pelos naturalistas e a visada "humorística" dos "futuristas", demonstra ser, novamente, a 
criação de uma "evolução" para a literatura com base na própria parcialidade e preconceitos de nosso crítico.

A interpretação que realiza sobre o tema do índio é própria dos preconceitos de época, quando ainda se supunha que o indígena era, de fato, como ele afirma, "uma criança que se vende ou vende os seus por um espelhinho, um berimbau ou um metro de baeta" (ibidem, p. 361). Daí ele supor apenas que se tratava de uma "idealização" da figura do autóctone pelos colonizadores, que poderia ser ou não utilizada pela fantasia dos escritores, sendo os românticos os que mais "carregaram" "na nota". Os preconceitos que trazia de sua formação ainda do século XIX só poderia mesmo enxergar como apenas humorística a "revistinha" dos modernistas paulistas. Imaginar outra recepção ou condenar a que teve o nosso crítico seria cair em anacronismo. A perspectiva crítica estava com os "futuristas" paulistas em que a crítica da linguagem poderia coincidir com a linguagem crítica $^{126}$.

Não obstante, se não é possível imputar uma perspectiva mais compreensiva a Nestor Vítor, é possível revelar aqui que a sugestão de que o naturalismo não conseguira ingressar no tema "indianista" por deficiência estética, mas que os "futuristas" paulistas o conseguiram, demonstra mais uma vez a associação, aí sim anacrônica, de Nestor Vítor, que continuava lendo os "futuristas" como herdeiros diretos dos parnasianos e dos naturalistas.

É preciso abrir um parêntesis na exposição do artigo de Vítor sobre Macunaíma para demonstrar o quanto essa leitura forjada, que via os "futuristas" como os novos "parnasianos", condenava a interpretação crítica de Nestor Vítor a um simplismo muitas vezes absurdo. Em um artigo sobre o livro Novos Poemas de Jorge de Lima, o crítico assim se pronuncia a certa altura:

\footnotetext{
De fato, entre a chave de ouro de Bilac e as 'pastilhas minorativas', que M. Bandeira pôs numa composição lírica, há certa correlação. Uma e outra cousa demonstram que parnasianos e "futuristas" encaram a arte como um brinco. Os parnasianos querem o soneto tal qual uma jóia de ourives: os "futuristas" acham que a "produção poemática" deve ser uma blague de crianças grandes, desabusadas.

(...)

Parece, pois: é aos "futuristas" que vai caber entre nós a herança dos parnasianos, quer do ponto de vista material, no referente ao jeton acadêmico, quer da própria popularidade, que é cousa mais nobre (OC, vol. II, p. 398-9).
}

126 Penso aqui na tese de João Luiz Lafetá, para o qual o projeto estético dos primeiros modernistas coincidia com seu projeto ideológico, de modo que a linguagem "humorística", nesse caso, não resultaria apenas em um efeito estilístico mas em certo compromisso com a crítica das estruturas sociais que se manifestavam também na linguagem bacharelesca e acadêmica que os primeiros modernistas buscaram destruir. Conferir 1930: A crítica e o modernismo, em especial, o capítulo de abertura: “Os pressupostos básicos”, p. 19-38. 
Se, sem dúvida, havia reminiscências da estética parnasiana na nova geração, também antes houvera no que se refere aos simbolistas (estes também beberam na estética parnasiana e seria impossível dissociá-los completamente ${ }^{127}$ ). Nestor Vítor, no entanto, só enxerga os "futuristas" pelo prisma acanhado, tacanho, das disputas literárias das décadas passadas. De alguma forma, mesmo considerando o valor intelectual de Mário de Andrade, não consegue lê-lo mesmo nessas produções de final da década de 1920, distante, portanto, da crítica que fizera aos naturalistas e aos parnasianos. Por isso, para explicar a "evolução" do tema do índio precisa necessariamente colocar os naturalistas no meio, explicando assim incidentalmente o próprio caráter "fescenino" do personagem Macunaíma.

Se os românticos idealizaram o caráter do índio, Mário de Andrade teria feito o inverso: "ele antes de tudo pô-lo sem caráter nenhum desde o título" (ibidem, p. 363). E na interpretação de Vítor, o autor também apresentara os personagens como crianças em um "processo onírico" e Macunaíma afeiçoado somente às mulheres e à preguiça: "É um semvergonha de uma marca tal como ainda não se vira" (ibidem, p. 363).

Não obstante, o que poderia adentrar um caminho moral, resume-se, no artigo, a estas palavras. Na verdade, em seguida, ele fará um grande elogio ao trabalho de pesquisa de Mário de Andrade que combina com o elogio que antes fizera em torno de o Clã do Jabuti.

\footnotetext{
Quase tudo é escrito como se fosse por um nosso caipira, e para isso, Mário de Andrade tem talento especial. Peculiaridades sintáticas, próprias ao falar do nosso povo do mato, frequentemente se apresentam. $\mathrm{O}$ vocabulário, no gênero, é de uma riqueza como ainda não se tinha visto em livro nenhum. A nomenclatura referente à nossa fauna, à própria culinária dos matos, até dos índios, por este Brasil afora, à produção das nossas pequenas indústrias e outras cousas assim, é abundante e superabundante.

Além disso, tudo até certo ponto, escrito com legítimo bom humor. Uma vez que que nos adaptemos à atmosfera fedorenta, bem freudiana do livro, lardeado de fescenismos a cada passo (...) (ibidem, p. 364).
}

Nestor Vítor capta nesse trecho o que Bosi afirmou ser a "mediação entre o material folclórico e o tratamento literário moderno" via "Freud" em Macunaíma (BOSI, 2006, p. 376). A própria valorização que o nosso crítico vinha fazendo do caráter nacional de alguns de nossos escritores, a exemplo do romance Flor de Manacá, de Breno Arruda, já citado, combinam-se bem com a crítica elogiosa a esse esforço de Mário de Andrade. Novamente, pela convergência de interesses, intenções, o crítico consegue adentrar de forma compreensiva no trabalho artística do escritor.

127 Trabalhei com essa ideia ao tratar do livro Broquéis de Cruz e Sousa em minha dissertação de mestrado. Ver Mescla estilística e ambiguidade em Broquéis de Cruz e Sousa (PAULA, 2013). 
Passado, no entanto, esse elogio, ele segue o artigo com a mesma crítica menos compreensiva que só conseguia ver uma "canseira crescente" na leitura dos diferentes capítulos do livro de Mário de Andrade.

Para encerrar o estudo sobre Macunaíma, sintetiza a própria visão que defende e que projetou sobre o modernismo e a sua ala "futurista", que é, em síntese, uma visão negativa.

\begin{abstract}
Seja como for, o que se torna patente na leitura de Macunaíma é isso: é que o dadaísmo europeu, passando para o Brasil e produzindo aqui um movimento literário dionisíaco de arremedo, vai, contudo, estimulando os nossos moços para tentarem uma literatura nacionalista que entre em simbiose com as particulares disposições nesse rumo que a guerra em toda parte suscitou.

Mas o grupo, aliás muito explicavelmente, sabendo-se o que o dadaísmo é, simpatizou com a ciência de Freud, de alcance moral com possibilidades as mais dissolventes.

O herói Macunaíma e todo o ambiente que em torno dele se vai criando, na sua peregrinação de sonho são francamente abjetos. Está vindo assim romanticamente, embora se pratique o romantismo às avessas, um neo-indianismo derrotista. $\mathrm{O}$ índio, visto com tão furioso freudismo, torna-se um símbolo antecipado da nossa bancarrota como povo no correr dos séculos.

Nesse sentido, pois, a tentativa de Mário de Andrade, a meu ver, é lastimável (ibidem, p. 365).
\end{abstract}

Com tais palavras tão duras, Nestor Vítor traz à tona com força o seu moralismo nacional: a imagem idealizada de Brasil que subordina as criações artísticas a um papel passivo que favoreça supostamente o "sucesso" de nosso "povo no correr dos séculos".

Com isso, ao observar a leitura de Nestor Vítor, encaro que ela é distante da que mereceu o elogio que Alfredo Bosi ao se referir ao nosso crítico. Segundo o estudioso:

(...) Pode-se, porém, confiar no tacto do seu impressionismo. Ele compreendeu, por exemplo, que o interesse pelos problemas nacionais traçara um sulco inapagável antes do Modernismo; e, sobrevindo, este, soube logo discernir os seus pontos altos: é um prazer vê-lo, sexagenário, entusiasmar-se com a leitura de Macunaíma de Mário de Andrade ou dos poemas afro-nordestinos de Jorge de Lima (BOSI, 2006, p. 316).

Se há entusiasmo de Vítor pela pesquisa de Mário em torno da linguagem e dos mitos de nosso folclore, este não é sustentado do início ao fim de seu estudo. A conclusão do artigo de Nestor Vítor destaca os "defeitos" e evidencia o olhar moral que o crítico tinha sobre a obra, de modo que as avaliações positivas, como disse, aparecem nos pontos que convergem a priori com a sua própria postura; não nascem, portanto, de uma leitura analítica do livro a partir de seus elementos constitutivos. Se a pesquisa e, logo, a intenção "nacionalista" é elogiada, o resultado da obra, não. 
No caso dos poemas de Jorge de Lima, também citados por Bosi, de fato há um elogio mais amplo por parte de Nestor Vítor. Mas, como antes, a partir dos aspectos que se mostram convergentes com a posição do moralismo nacional do crítico, rejeitando os aspectos que considera "excessivos" recursos dos "futuristas".

Em artigo de abril de 1928, escrevendo sobre o livro Poemas (1927), afirma que o livro é "quase que uma ironia só" e a "ironia é um dos aspectos mais essencialmente característicos dos modernistas que vêm, mais ou menos proximamente, dos Dadás" (OC, vol. II, p. 392-3).

Após indicar que a ironia é um "tal dadaísmo" adotado por rapazes das revistas Klaxon e Terra Roxa, aponta que um dos melhores poemas do livro de Jorge de Lima, "Pai João", mescla a ironia de "feição futurista" com "uma sensibilidade no íntimo até muito romântica, e de poeta legítimo" (ibidem, p. 393). Conclui, assim, que os Poemas "do sr. Jorge de Lima estão muito longe de ser ortodoxos. Acusam, pelo contrário, frequentes movimentos de recuo na sua feição interior, ingenuidades imperdoáveis de um muito incompleto converso" (ibidem, p. 394).

Em outras palavras, Jorge de Lima não é um "futurista integral” como ele afirma sobre Mário de Andrade, daí que o seu livro de poesia "há de ser lido necessariamente pelo geral com muito mais agrado, sem dúvida, que os de quantos outros poetas vanguardistas até aqui se conheciam no Brasil” (ibidem, p. 394).

Assim, se há "entusiasmo" do sexagenário Nestor Vítor, esse é ainda alcançado a partir da correspondência com os critérios de uma crítica que não se estabeleceu necessariamente após 1922, o ano da Semana de Arte Moderna ou da revista Klaxon. Portanto, é um entusiasmo, nesse sentido em particular, de um passadista vendo nos novos a confirmação de seus próprios pontos de vista já não completamente integrados à "hora atual".

Não é estranho, por exemplo, quando ao tratar, em outro artigo, de "Essa Negra Fulô" e "Banguê", o crítico chegue à interpretação de que Jorge de Lima conseguiu a fusão do vanguardismo com o espírito "nacional”: "O Sr. Jorge de Lima presta assim um serviço real ao vanguardismo brasileiro: aproxima, incontestavelmente, a sua estesia, do gosto mais geral. É milagre que só o Norte com o seu senso profundamente nacional podia fazer" (ibidem, p. 397). 
A divisão entre Norte e Sul do país já se apresentara em vários momentos da obra do crítico $^{128}$ : o primeiro como mais tradicionalista e o segundo como mais inovador. Nesse final de sua carreira, diante do poder cada vez maior de São Paulo, sobretudo, vez ou outra, recorre aos autores provenientes do nordeste brasileiro para ancorar uma tradição literária mais nacional, mais "genuína". Embora, quando autores se alinham às tendências em arte que Vítor rejeita, ele não se importa com a origem, apenas com o destino da influência que os escritores podem criar no ambiente cultural brasileiro.

Assim é o sentido do último artigo que comentarei, "Nossas Letras no Centenário de José de Alencar", de maio de 1929, que serve como um julgamento pessimista da criação dos "futuristas" que tem se espalhado por todos os Estados e que revela mais uma vez a aposta de Nestor Vítor pelo grupo dos espiritualistas.

Segundo o crítico, a nova geração é formada por uma massa de leitores e de produtores muito maior que a das gerações anteriores. Um ambiente mais restrito do passado permitia aos "velhos autores", da "época dos românticos", da "hora dos naturalistas", do “instante dos simbolistas", que lessem apenas "meia dúzia de livros" e isso já lhes habilitava "a ser quem foram. Em tal sentido, nenhum trabalho foi esse comparado com aquele a que se veem forçados os jovens de hoje para valer alguma cousa entre seus contemporâneos" (OC, vol. II, p. 420).

Com efeito, a ideia de que a produção de livros, de leitores e de autores aumentou enormemente já havia aparecido em artigos do final dos anos de 1910, ao escrever a novos escritores que também eram críticos, a exemplo de Andrade Muricy, ou ao observar o sucesso editorial de obras como a de Monteiro Lobato. Uma maior quantidade poderia favorecer uma maior qualidade na produção literária, de modo que o surgimento de uma maior erudição seria um cenário favorável às exigências do crítico que defendera no passado o "ascetismo intelectual" dos escritores.

No entanto, a apresentação dessa situação das letras nacionais no início do artigo não objetiva criar um clima otimista para a produção literária. Esse prisma inicial servia, na verdade, para criar um contraponto à existência dos "futuristas" e de suas últimas manifestações, já que estes aparentemente ignoravam o clima de maior exigência intelectual.

Na percepção de Vítor, os "rapazelhos" de "sensibilidade menos plástica ou de leitura mais deficiente" tornaram-se adeptos dos "futuristas", inundando "jornais e revistas de 
pastichos quase sempre insignificantes, quando não irrisórios" (ibidem, p. 421), o que o levava a condenar toda a corrente como funesta à arte.

\footnotetext{
Não é para menos, pois em tal fenômeno verifica-se que essa escola só pode servir para desprestígio da arte, confundindo a infantilidade com a poesia. Aliás, entre os chefes há quem pregue como ideal chegar-se até a cretinização: a Revista de Antropofagia não faz outra cousa (ibidem, p. 421).
}

A crítica faz evocar o mesmo julgamento que ele tivera das revistas e jornais mundanos no período da belle époque. O "desprestígio da arte" agora seria fruto da ação da "escola" futurista.

Em seguida, após essa crítica inicial, ele indica, como é seu costume, a formação dos grupos na vida literária, o que permite que ele julgue negativamente aos "moços que já não são verdinhos e alguns velhuscos" que buscam se aliar aos "futuristas" para continuar "bem do instante" (ibidem, p. 421).

Trata-se, de fato, de uma crítica indireta a escritores, como Graça Aranha, que buscaram se aliar aos "futuristas", o que os tornariam mais medíocres que estes, que, afinal, de acordo com Vítor, não são entendidos mesmo pelo público, o qual sempre supõe que estes estejam "troçando". Ao lado dos "futuristas" e de seus adeptos de leitura deficiente ou "velhuscos", há "os que trabalham a sério" e que para fugir da "humilhação" que aqueles provocam, "tornam-se sumamente antipáticos" (ibidem, p. 421).

A referência que parece um tanto enigmática a princípio, já que ele não nomeia esses "antipáticos", pode ser explicada se pensarmos no "confronto" entre dois grupos que se fizera mais patente em 1928: o grupo dos espiritualistas ligados à revista Festa, que tinha à frente Tasso da Silveira, e o grupo da Revista da Antropofagia, que tinha à frente Oswald de Andrade. Nas duas revistas, apresentaram-se posições divergentes no que se referia à arte e à tradição literária nacional, que, de forma indireta, Nestor Vítor busca aqui situar.

Araújo (2011) expõe a oposição entre o grupo "primitivista", cujos expoentes seriam Oswald e Mário de Andrade, e o grupo "espiritualista”, cuja liderança estava com Tasso da Silveira. Na descrição dos dois grupos, percebe-se que a presença do passado e o pressuposto moral deveriam sustentar a defesa de Vítor em relação aos espiritualistas de Festa.

Enquanto na primeira [a corrente primitivista] reuniam-se escritores que buscavam explicar o Brasil, voltando-se às suas origens, aspirando construir a identidade nacional de seu povo; a segunda, sem romper completamente com o passado, buscava, através da espiritualidade, compreender a modernidade e indagar sobre o destino do homem. Os primitivistas tinham como projeto a renovação radical da 
estética e a redescoberta da identidade brasileira por um processo de retomada cultural. Os espiritualistas buscavam, via literatura, restaurar os valores morais perdidos na praticidade dos dias modernos, através da valorização do espírito humano (ARAÚJO, 2011, p. 98).

Ainda conforme Araújo (2011), o grupo que forma Festa defendia um tipo de modernidade literária que dialogava com o passado a partir de traços de "continuidade, não de ruptura" e se opunha ao "materialismo e ao cientificismo" (ARAÚJO, 2011, p. 100). Defesas que também funcionavam muito no discurso de Nestor Vítor.

Na primeira fase da revista Festa, foram produzidos doze exemplares, de 1 de agosto de 1927 a 15 de setembro de 1928. Fase que Vítor pôde acompanhar e assim, contrapor, à existência de outras revistas, como a Revista da Antropofagia, citada no artigo "Nossas Letras no Centenário de José de Alencar”. A oposição entre as revistas é também percebida por Araújo.

\begin{abstract}
O nome da revista foi inspirado no título do romance A Festa, de Tasso da Silveira, publicado no ano anterior. Causa de várias críticas, já que a revista se impunha pelo tom de séria reflexão crítica, afastando-se do espírito brincalhão de Klaxon ou da alegria irônica de Oswald de Andrade na Revista de Antropofagia.

(...) O grupo de Festa reivindica, com a publicação da revista, para o Rio de Janeiro (na verdade para si), a prioridade na renovação da arte brasileira, em oposição ao que estava sendo feito, ou tinha sido feito pelo grupo de Oswald de Andrade e outras correntes literárias desde a Semana de Arte Moderna de 1922, em São Paulo (ibidem, p. 103).
\end{abstract}

Conhecendo o contexto, de oposição entre as revistas e os grupos, é que se pode compreender o sentido das palavras de Nestor Vítor no artigo. Por meio da própria revista Festa, em 1928, em apologético artigo intitulado "O Brasil que será: a revista Festa”, o crítico já havia afirmado que "a arte nunca foi, nunca será inócuo passatempo. Ela ou faz bem ou faz mal" (OC, vol. II, p. 387),

A disputa no campo literário fazia-se novamente, no universo de concepções de Nestor Vítor, entre a arte séria, elevada, e a arte feita por "troça" ou para "escandalizar" o público. Não é à toa o paralelo, já apontado, que o crítico estabelecia entre os adversários do passado e os "futuristas" do presente. Mais do que semelhanças "formais" ou de "linguagem", o que se processava na visão do crítico era a disputa pela apropriação do capital simbólico disponível.

Efetivamente, a narrativa que ele construía em seus artigos, seguindo também as posições que Tasso da Silveira desenvolvia na revista Festa, é que o vanguardismo não nascera com os "futuristas" da Semana de Arte Moderna e que estes, influenciados pelas 
vanguardas europeias, não atuavam com a seriedade exigida pela arte e pela tradição literatura brasileira.

Araújo (2011) reproduz em seu artigo, inclusive, trechos do confronto entre Tasso da Silveira e os "andradistas", que poderiam muito bem figurar nos escritos de Nestor Vítor. Aliás, a crítica à "ironia" dos futuristas, citada antes por mim, aparece tanto em um quanto em outro. Vale a pena reproduzir alguns desses trechos que tornam mais elucidativo o próprio sentido da crítica de Nestor Vítor:

Mário de Andrade escreveu sobre Festa uma página de homem. De adversário, mas de homem. (...)

A primeira e mais importante, é que o grupo de Festa vivia apagado, à parte (antes do aparecimento da revista), e que a agitação, a vida nova, principiou com a gente da semana de arte moderna. Para ele, nós entramos na dança agora. Na hora de repartir os proveitos.

Manhosamente [...] Ora, a verdade é que o grupo de Festa, pelo menos por alguns de seus elementos, vem atuando intensamente, sempre no mesmo sentido, desde 1919, menos característico do que hoje. Mas já dentro do rumo largo que se abriu a golpes fundos de tenacidade espiritual (SILVEIRA, Tasso da. Festa, Rio, n ${ }^{\circ}$, fev. 1928 apud ARAÚJO, 2011, p. 102).

Como se vê, Tasso defende que a renovação se processara antes da Semana e que ele, como outros, já buscavam coerentemente desde 1919 (ano de fundação da efêmera revista América Latina) traçar o panorama da nova literatura.

Além disso, ao qualificar essa empreitada anterior de "tenacidade espiritual" provavelmente remetia ao movimento espiritualista que vinha ao menos desde meados da década de 10 e que poderia encontrar suas fontes em Jackson de Figueiredo, Farias Brito e Nestor Vítor.

Depois de responder a Mário de Andrade, Tasso volta-se contra Oswald, respondendo a uma carta deste, em outro número da revista. Ele busca se pronunciar a favor da seriedade, da "gravidade".

Um dos líderes do cendrarsismo nacional, vulgo pau Brasil, perguntou-nos em carta por que fazemos "uma festa tão triste" ... (ô meu querido Brazílio Itiberê: manda um pouco das tuas tintas de sol para iluminar as paisagens anêmicas das novelas russas de Oswald...).

Oswald: eu escrevo as minhas páginas mais graves em alegria. Porque a alegria é grave. E danço maxixe como ninguém... Mas detesto a ironia, porque é dos céticos. E detesto a galhofa imbecil, porque é dos entediados e vazios (SILVEIRA, Tasso da. Festa, Rio, nº 9, abr. 1928, apud ARAÚJO, 2011, p.103). 
Com efeito, tendo esse tipo de colocação como pano de fundo, entende-se a afirmação de Nestor Vítor em torno do grupo que "trabalha a sério" e que parece, inclusive, "antipático", porque quer fugir à "humilhação" que o grupo de futuristas da Revista da Antropofagia parecia produzir diante do público.

O panorama que Nestor Vítor traça então em 1929, no centenário de nascimento de José de Alencar (que sequer é citado ao longo do artigo!), é que a produção da nova geração, embora em grande quantidade, é comercial, sem grande valor, e tem se disseminado por todo país e assim ele encerra o artigo.

\begin{abstract}
Daí por toda parte um relaxamento geral. Por todos os Estados, aqui mesmo no Rio (em tal sentido cada vez mais provinciano), gente que já escreveu melhor agora anda produzindo fancarias. Ombreia-se assim com jovens ineptos que, surgindo nesta abastardada atmosfera, andam impantes, julgando que valem alguma coisa. É uma comunhão cada vez mais crescente no desmancho. Os suplementos dos jornais, quase todos feitos para agradar a massa, em vez de ser para orientá-la - como acontece na Argentina, no Uruguai - dificilmente se organizam. (...)

Leitura, pois, não falta. Um crítico tem sempre à mesa grande pilha de livros, opúsculos e folhetos. (...) O que falta muitas vezes é cousa da qual valha a pena falar, mesmo que seja para não dizer muito bem (OC, vol. II, p. 422).
\end{abstract}

Como afirmei, a descrição poderia evocar as que ele fazia na belle époque, quando denunciava o mundanismo de revistas e jornais e criticava o gosto público, afeito à moda dos parnasianos ou naturalistas, dos "queridos" Coelho Neto e Olavo Bilac.

A história parece se repetir: os "futuristas", na visão de Vítor, se "multiplicam" e o grupo que apoia, não. Em 1929, começava a segunda "dentição" da Revista da Antropofagia criticada por ele no artigo, enquanto a revista Festa parara de circular. Mais uma vez, a aposta de Nestor Vítor no campo literário o conduziria a um papel secundário. A historiografia literária em torno de seu nome acabou por confirmar isso. 


\section{CONSIDERAÇÕES FINAIS}

Do projeto apresentado ao trabalho concluído, há um caminho que talvez possa tornar mais claras algumas questões desenvolvidas até aqui.

No projeto, havia dois problemas básicos. Ler a obra de Nestor Vítor buscando revisar o seu papel como "crítico do simbolismo", presente na historiografia; e encarar as representações em torno do simbolismo que se construíram também na historiografia e que deram uma espécie de "vitória simbólica" ao movimento, apesar de sua pequena consagração no período de seu surgimento.

Com a leitura mais sistemática da obra crítica de Vítor, com a leitura da obra da tríade crítica do século XIX, com o conjunto de leituras que realizei que se materializaram no presente trabalho, pude reavaliar minhas pretensões e hipóteses iniciais, encarando, de um lado, que a história da crítica literária no Brasil estava, em linhas gerais, correta na apreensão que fez do lugar de Nestor Vítor e, de outro, identificar que o ganho "simbólico" dos primeiros simbolistas não foi tão tardio assim, como me parecia inicialmente, porque havia relações materiais (como a divulgação de obras e de autores) que ampliaram a circulação do simbolismo e de seu prestígio ainda na Primeira República.

Talvez existisse em meu projeto inicial e nas hipóteses iniciais a ideia, de fundo romântica, de que eu pudesse enxergar em Nestor Vítor um crítico de envergadura muito maior do que, de fato, ele era. Talvez existisse a pretensão de "descobrir" um autor, que, a exemplo de Cruz e Sousa, teria sido relegado, no momento de sua criação, a um papel menor. Mas esse tipo de "descoberta" pode ser bastante ideológica, uma espécie de "encobrimento" por meio da leitura de supostos "traços geniais", "antecipatórios", ou algo parecido.

A leitura e a utilização (um tanto reticente, como dizia ao meu orientador) de autores como Terry Eagleton, Raymond Williams ou Pierre Bourdieu me preveniram de querer encarar o "método crítico" de Nestor Vítor como algo de excepcional ao contexto. Esta, com certeza, nunca foi minha pretensão: apreender o método crítico de Nestor Vítor e colocar as minhas considerações ao lado dos estudos sobre os métodos críticos de Araripe Júnior, José Veríssimo ou Sílvio Romero.

O objetivo inicial era identificar a leitura de Vítor acerca do simbolismo e desfazer ou não equívocos da historiografia em torno de seu nome. Era essa a pretensão. Isso porque, como afirmo ao longo de todo o texto, se o legado de Nestor Vítor é sua relação com Cruz e 
Sousa e o simbolismo, não é possível ler Cruz e Sousa e nosso simbolismo sem conhecer minimamente a obra do crítico ou o contexto cultural do qual um e outro são dependentes. Quer dizer, é possível, e assim tem sido feito ao longo das últimas décadas, mas à custa de desenvolver uma leitura que abstrai certos traços inscritos na obra dos simbolistas, os quais estão ligados aos contextos de criação e de crítica no período da República Velha.

Assim, na tentativa de "desfazer possíveis equívocos", acabei me convencendo e espero que isso seja visível no texto produzido de que o crítico, de fato, foi um crítico secundário, menor, como já haviam dito os textos de nossa história literária. Mas que esse lugar, o de crítico menor, secundário, era relevante justamente por permitir um olhar sobre o fazer literário, sobre o campo cultural, diferente do que já se revelara nos estudos sobre os críticos consagrados da geração de 1870.

Por esse caminho, na tentativa de encontrar uma excepcionalidade na obra de Vítor, pude, na verdade, ver um ponto de vista que já foi identificado em outros estudos, como os de Roberto Ventura, Luiz da Costa Lima, ou mesmo Brito Broca, que está ligado às disputas, às polêmicas que conformavam a vida dos homens de letras tanto nas últimas décadas do século XIX quanto no início do XX.

Nesse sentido, a referência a esse período de nossa história não serve apenas como contorno contextual. Como busquei demonstrar ao longo dos capítulos, o fato da obra de Vítor ter se realizado no momento em que se realizou produziu efeitos tanto em suas elaborações internas quanto em sua recepção.

Assim, procurei, por exemplo, revelar a relação entre os seus primeiros textos críticos e o clima de agitação e de "combate" dos primeiros anos da República. Ao me referir à sua produção inicial, vinculei-a ao clima de contestação intermitente que marcava os anos 90 do século XIX (NEEDELL, 1993).

Assim, ainda que sem me aprofundar na questão, discuti a tese de que o simbolismo não participava da formação social brasileira, conforme formulado tanto em José Veríssimo (1901), quanto em Alfredo Bosi (2006), a qual já fora questionada por Luiz Alberto Souza (2017). Busquei relativizar tal tese ao descrever a posição de Nestor Vítor como parte de uma prática alternativa de crítica e de pensamento que, por sua vez, representava anseios de uma parcela da intelectualidade pequeno burguesa que aparecera no cenário político-social no início da República (SILVEIRA, 2010; NEEDELL, 1993) e que se expressaria também anos depois na tentativa de eleição de Rui Barbosa para a presidência do país (FAUSTO, 2001). 
A partir da compreensão dessas condições históricas que são também condições sociais de produção intelectual, o tipo de "espírito grupal" que Nestor Vítor exibiu (MARTINS, 1981), sempre enxergando agrupamentos, disputas e valores conflitantes, parece ganhar um sentido mais complexo. Ou seja, deixa de ser apenas um traço de estilo do crítico para responder a uma dinâmica social mais ampla.

Efetivamente, a crítica na República Velha só poderia ser enformada por polêmicas e disputas. Um tipo de espírito "combatente" parecia agrupar os homens de letras que vivenciaram a experiência da Abolição e da instauração da República. A virada do século XIX e os primeiros anos da belle époque, ainda que amenizassem os conflitos agudos que marcaram esses dois eventos históricos, não retiraram por completo de todos os homens de letras o espírito de contestação. Este se manifestava nas polêmicas culturais entre os representantes dos mais diferentes movimentos e estéticas.

Com essa perspectiva que já não era inicial, já não era do projeto de doutorado, mas parte da leitura da obra do crítico e do suporte de leituras que eu realizava, pude escrever os dois primeiros capítulos da Tese. A relação entre a obra e o contexto, que é esboçada no primeiro capítulo, e a observação do campo literário, do ambiente cultural a partir da leitura dos textos do crítico foi fruto então, ao mesmo tempo, da aceitação do caráter secundário de sua crítica para o momento de sua produção e o significado desse caráter secundário, extraindo desse lugar, e não de uma função especial de sua crítica, as possíveis contribuições para a compreensão das relações literárias na República Velha. A partir da expressão "política literária", pude apresentar a visão do crítico sobre os processos de consagração ou não de obras e escritores, sobre o processo de canonização.

A expressão "política literária", aliás, me foi imposta por sua recorrência nos textos após os anos de 1910. Ela pôde ser instrumentalizada, talvez até um pouco anacronicamente, ao avaliar os textos do crítico do final do século XIX, porque, como tentei demonstrar, a leitura crítica de Nestor Vítor nunca foi puramente "interna", nunca incidiu somente sobre os elementos constitutivos da peça literária. Do início ao fim de sua produção, ele relacionava produção artística e recepção crítica.

Desde o primeiro texto, ele compreendeu que a criação não excluía interesses materiais, como a necessidade de publicação e de leitura, e que a recepção não excluía parcialidade, ainda que interesses e parcialidade se chocassem "programaticamente", em tese, 
com os pressupostos da corrente "místico-simbolista" a que ele se associara ainda nos anos de 1890. A dualidade de perspectivas, que podem, abstratamente, ser consideradas, opostas ou contraditórias, combinam-se, na realidade, ao longo de sua produção, havendo predomínio de uma ou de outra conforme estabeleçamos "fases" de sua obra, que foi o que fiz, de forma não rigorosa (como expediente "didático" para a apresentação dos textos), para entender as transformações de seu olhar crítico sobre obras e autores.

A partir das leituras e da escrita inicial, recorri então, não elegantemente, a muitos trechos e a trechos longos da obra de Vítor, para demonstrar a quantidade de verdadeiros "achados" que sua perspectiva proporcionava.

Em alguns de seus textos, as considerações sobre Sílvio Romero e José Veríssimo nos fazem lembrar os bons estudos que foram feitos sobre estes críticos já na segunda metade do século XX. Os limites apontados nos críticos da "Geração de 1870" puderam ser vistos de forma muitas vezes acurada por nosso crítico. E isso ainda quando aqueles estavam no auge do prestígio ou então, como acontece nos fins dos de 1910, haviam acabado de falecer e suas obras ganhavam uma aura ainda mais respeitável. Ler esse “crítico menor", "secundário" em confronto com a obra e a leitura que se fez dos "maiores" e "principais" parece ser algo de interessante que consegui esboçar sobretudo no segundo capítulo, o que me parece ajudar a reconstituir o espaço de criação e de crítica, com as possibilidades inscritas naquele momento.

Isso me permitiu também revelar algo que não aparece na historiografia em torno de Vítor: a ideia de que ele também carregou traços do modelo naturalista de crítica, que ele também esteve imbuído de cientificismo, o que permite criar uma intersecção com todos os críticos daquele período, possibilitando uma leitura mais compreensiva das transformações que a crítica literária sofreu no período da República Velha.

De igual maneira, não posso também ignorar nesse caminho entre o projeto e a tese escrita, a grata surpresa que foi comparar os escritos de Nestor Vítor sobre a "vida literária" do período com a que apontavam outros estudiosos como Nicolau Sevcenko, Jeffrey Needell, Brito Broca, etc. Fugindo um pouco do interesse inicial, os trechos comentados sobre a Academia Brasileira de Letras, sobre os literatos da belle époque, sobre o jornalismo, etc., reforçavam o que eu busquei expressar ainda no primeiro capítulo: a íntima relação entre contexto sociocultural e a produção dos textos críticos.

A leitura que se fez mais contemporaneamente da permanência e dominância dos parnasianos e dos naturalistas no meio cultural brasileiro, para além da extensão destas 
estéticas na Europa, revelando, por um lado, a sua ligação com os gostos e o pensamento das elites brasileiras (SEVCENKO, 2003), e, por outro, confirmando mais uma vez, por oposição, a situação social dos simbolistas e daqueles que buscaram se vincular a esse movimento, também já aparecia no horizonte de interpretação de nosso crítico.

Os artigos analisando a posição social de Coelho Neto ou Olavo Bilac ou a crítica ao mundanismo das revistas e jornais da belle époque colocaram Nestor Vítor em uma espécie de pioneirismo na explicação "sociológica" do isolamento dos artistas alinhados ao simbolismo.

A crítica de Vítor então esteve enfeixada nas condições sociais criadas pela Primeira República, tanto no que se relaciona ao seu clima político quanto ao seu contexto cultural. Como tentei demonstrar, além do caráter combativo de sua crítica, ela também participou das modas e dos valores dominantes que marcavam esse período. Assim, tanto no período da belle époque quanto na época da Grande Guerra, ele acabou por participar, com seus escritos, das diretrizes do pensamento que atuava nos diferentes campos da vida social.

Mesmo que ele tenha sido um crítico do "mundanismo" e do reflexo deste nas instituições culturais, ele acabou por refletir tal mundanismo na valorização que ele encarnava dos ideais normativos da "civilização" (EAGLETON, 2011). Do mesmo modo, sem ser um adepto ortodoxo da reação católica ou nacionalismo autoritário que já apresentavam suas matrizes teóricas em meados dos anos de 1910, ele acabou por legitimar autores vinculados a essas tendências, a exemplo de Jackson de Figueiredo ou Alberto Torres. A própria leitura que realiza da obra de Farias Brito termina por convergir em uma curiosa defesa de um espiritualismo de base nacional, o que, mais uma vez, parece-me confirmar a ideia da relação entre o contexto de produção e a própria obra analisada.

Essa ideia aliás, de fundo materialista, aparece nem sempre explicitamente nos terceiro e quarto capítulos, mas é fundamental para explicar a relação de Nestor Vítor com o movimento simbolista, com os autores alinhados a esta estética e para afirmar, negar ou relativizar a noção corrente de que Vítor foi o "crítico do simbolismo".

Outrossim, além de participar, em seus textos, das contradições e das vicissitudes de sua época de transição, a República Velha, a produção intelectual de Nestor Vítor escolhida por mim para análise também foi uma "crítica literária" no sentido a partir do qual se compreendia a crítica literária no século XIX e início do XX aqui no país. 
Uma crítica voltada a criar um panorama das relações culturais que enformavam a produção dos textos, os quais, por sua vez, nem sempre enquadrados nos gêneros considerados literários, como se pode verificar nas leituras que Vítor realizou das obras de Farias Brito e de outros escritores não ligados diretamente à produção de romances, contos ou poesia. Uma crítica voltada a interpretar os textos e a sua relação com o ambiente cultural e histórico em sentido amplo (EAGLETON, 1991) e não somente a identificar apenas os elementos "internos" e "constitutivos" da peça literária como se começou a compreender um pouco mais tarde no século XX (WELLEK, 1972), mas que existe também nos textos de Vítor desde a monografia Cruz e Sousa, de 1896.

A possível oposição entre um olhar voltado para o meio cultural e outro que busca interpretar e elogiar autores e obras alinhadas a determinada estética e movimento aparece em Nestor Vítor pela alternância de textos que refletiram, em momentos distintos, exigências e demandas e que puderam ser avaliadas por mim a partir das "fases" que elenquei de forma não rigorosa para captar os movimentos de sua obra, sem que cada "fase", de fato, oponha-se às demais.

Espero, nesse sentido, que o terceiro capítulo tenha conseguido revelar como Nestor Vítor em sua produção conseguiu juntar termos aparentemente antitéticos; como o simbolismo pôde ser lido de diferentes formas sem que ele houvesse que simplesmente abandonar tudo o que antes defendera; e como suas defesas respondiam a contextos concretos de produção, a exemplo do uso da noção de cosmopolitismo, aplicada em fins do século XIX para se opor à visão limitada do que deveria ser a crítica e a criação literárias, mas que nunca significou um abandono completo do nacionalismo. De forma semelhante, que a discussão de critérios étnicos, rejeitados ou aceitos, na leitura em torno do poeta Cruz e Sousa, possa ser lida a partir da necessidade que o crítico teve em responder às posições existentes nos diferentes campos em que ele, de forma mais consciente ou não, teve de participar.

Assim, se ele não compartilhou tão voluntariamente as modas da belle époque, ele aderiu de forma mais consciente a um moralismo nacionalista que vicejou durante e após a Primeira Guerra Mundial. Uma adesão que, transposta para o campo literário, assumiria a forma de defesa da tradição romântica brasileira, com sua "música interior", com sua "linguagem" idealizada e com seus temas "tão nossos".

Aliás, o retorno do nacionalismo literário na crítica de Nestor Vítor revela bem a fragilidade do campo literário brasileiro na República Velha. 
Como afirmei, o cosmopolitismo no início de sua produção refletia o internacionalismo encarado positivamente em um período anterior a Guerra (conformado sobretudo no período da belle époque). Com a Guerra, verifica-se o desmoronar das antigas crenças do crítico (SILVEIRA, 2010) e uma valorização excessiva do critério de correspondência entre as obras literárias e os sentimentos e valores "legítimos" do povo brasileiro. Nestor Vítor atualizava aí o antigo dilema de nossa cultura e de nossa literatura entre cosmopolitismo e nacionalismo (CANDIDO, 2006).

A noção de "gênio" isolado para quem a "pátria" é ainda um espaço reduzido desmorona junto à civilização europeia que se convulsiona com a Guerra e a Revolução Russa. Assim também a defesa da "arte pura" e dos imperativos de uma ética profissional que se identifica com a defesa do estético (SAPIRO, 2011) perdem força diante do compromisso do intelectual diante da imagem de Brasil que deveria emergir após os conflitos mundiais.

A maior participação do homem de letras nos "novos tempos" aparece então após a Guerra como uma espécie de responsabilidade objetiva, como uma espécie de implicação moral. A seriedade intelectual sempre exigida por Nestor Vítor em relação à obra de arte transforma-se, no final dos anos de 1910, em preocupação com os efeitos morais dos textos sobre a imagem do Brasil que queria reforçar, validar.

O terceiro capítulo representou, desse modo, a tentativa de responder mais abertamente às minhas preocupações e interesses, explicando de uma forma mais abrangente a relação de Nestor Vítor com o simbolismo e daí com o papel que encarnou na historiografia literária. Faltava, no entanto, ainda que reconhecido que Vítor teria sido um crítico "menor" e "do simbolismo", mostrar que ele não havia sido somente isso. Faltava, ainda que brevemente, apresentar sua produção dos anos 20, a qual, embora voltada também a rememorações e balanços do simbolismo, também se debruçava sobre as novas criações artísticas, sobre as experimentações das vanguardas.

Desse modo, tendo sido sempre pensado como um capítulo "menor" em relação aos anteriores, o último capítulo sintetiza a necessidade de mostrar, ainda que não de forma exaustiva, como ocorre nos segundo e terceiro capítulos, aspectos da leitura de Vítor sobre o movimento modernista que se colocava no horizonte cultural do período.

O tema que pode ser mais interessante para a fortuna crítica do movimento modernista em nosso país é, entretanto, “menor" também no sentido de ser menos original, porque já 
parte das considerações e análises realizadas nos capítulos anteriores. É uma espécie de aplicação do que antes apresentei. Há nele, de forma sintética, a consciência que Vítor avaliava a literatura a partir das disputas no meio, de que lia os autores e obras a partir das relações extraliterárias, de que ele já vestira a roupa do passadismo e enxergava as novas estéticas como desdobramentos das que ele já conhecera em sua juventude e maturidade intelectual.

Desse prisma, ao falar sobre a recepção do modernismo pelo crítico, pude dialogar com a concepção corrente de que o crítico atuava sempre de "forma simpática" e que este, inclusive, seria uma espécie de método para aproximação com as obras literárias (SILVEIRA, 2010). De fato, havia muito de atitude "simpática" e "cordial" nas interpretações de Nestor Vítor. Ele, ao longo de mais trinta anos, encarou as mais diferentes produções das gerações que se sucediam. Analisou escritores alinhados ao simbolismo, mas também ao parnasianismo, ao naturalismo, ao romantismo. Leu autores os mais divergentes, desde Ibsen a João do Rio e, acima de tudo, nunca se furtou a comentar os novos escritores, chegando, em um esforço mais intenso, já sexagenário, buscar compreender minimamente a criação dos “futuristas" paulistas e sua relação com as vanguardas europeias (BOSI, 2006).

Os últimos anos de sua produção crítica poderiam ser lidos, assim, como um esforço para elucidar o que se produzia na nova geração de "vanguardistas" e quais os rumos que esta produção seguiria a partir de então.

Obviamente, a sua leitura foi atravessada por toda a sua experiência anterior: as lutas pelo ingresso no campo literário, as suas tomadas de posição em relação aos adversários e aos "aliados", as concepções em torno da arte, as transformações no ambiente cultural, os modelos críticos preexistentes, etc.

Assim, leu os modernistas basicamente com os olhos do passado, ainda que, vez ou outra, pudesse enunciar julgamentos que seriam consolidados nos próximos anos, como o elogio aos esforços de Mário de Andrade em sua "cruzada" de descoberta nacional ao comentar sobre os livros Clã do Jabuti e Macunaíma.

Além disso, o seu olhar "passadista" também poderia ser observado na maneira como interpretava a oposição entre espiritualistas da revista Festa e os "futuristas" paulistas, visto como uma reatualização das antigas disputas entre simbolistas-decadentistas, de um lado, e parnasianos-naturalistas, de outro. 
O quarto capítulo, com essas pretensões, realizou-se, assim, de forma mais modesta. Busquei apenas revelar como os critérios e os valores já mais ou menos cristalizados na crítica de Vítor se atualizaram na disputa entre dois aparentes grupos. Como ele apresentava essa disputa e como ele se posicionava, assumindo o lado dos espiritualistas. Os desdobramentos dessas duas supostas "alas" e as consequências para a literatura posterior não eram meu objeto. O capítulo serviu para reafirmar o objetivo de ler a historiografia em torno de Vítor. Nesse caso em específico, revisar a apreensão que Alfredo Bosi teria feito do crítico.

Com os capítulos projetados concluídos, vejo que ainda muitas questões poderiam ter sido desenvolvidas. O espaço entre Vítor e os três críticos consagrados, por exemplo, poderia ser ampliado para estabelecer conexão com os demais críticos do período como João Ribeiro, apenas duas vezes citado em sua obra ou estabelecer as relações de choque com os demais grupos não dominantes que existiram, além da coterie inicialmente liderada por Cruz e Sousa e da qual participara Nestor Vítor. Wilson Martins, por exemplo, chega a comentar a oposição do crítico em relação a Alphonsus de Guimaraes e há algumas indicações dessa oposição na obra analisada por mim, mas o desenvolvimento dessas relações mais amplas e que, com certeza, enriqueceriam a análise do campo pareciam exigir outros capítulos e outras pesquisas que, em última instância, não conseguiriam esgotar o conjunto de relações que a obra de Nestor Vítor estabeleceu com o meio cultural.

Igualmente, a apresentação, às vezes, um tanto corrida de autores e obras, perseguindo apenas alguns traços da leitura de Vítor, inviabilizou um estudo mais detido das análises críticas propriamente ditas. Mais uma vez, havia uma impossibilidade, diria objetiva, de ler todas as obras comentadas e avaliar o grau de aproximação ou distanciamento com outras leituras realizadas no período ou posteriormente, o que exigiria talvez também capítulos à parte, e mais do que isso, colocaria sobre outra forma a leitura do "método crítico" ou a “descoberta" de uma "leitura genial” do crítico que eu já havia abandonado quando iniciei as leituras. Pode-se, apesar disso, acompanhar algo da análise que o crítico realiza em torno de um autor específico, Cruz e Sousa. Busquei resgatar todos os textos em que há uma apreciação crítica, porque a associação entre um autor e outro é inequívoca e precisava ser analisada. Assim, do primeiro ao terceiro capítulo há referências e interpretações em torno da leitura que Nestor Vítor fez da obra do poeta simbolista. Penso que, no futuro, a partir do trabalho apresentado, outros estudos sobre escritores analisados por Vítor possam identificar 
as contribuições do crítico que até então eram desconhecidas e o que presente trabalho buscou apresentar.

Espero, contudo, que essas faltas, algumas das quais, inclusive, talvez enfraquecedoras do trabalho apresentado, sejam minimamente compensadas por um objetivo que percorri desde o projeto até aqui: ampliar a divulgação da obra de Nestor Vítor. As repetições, a definição sistemática de períodos e os longos trechos funcionam, de alguma forma, para permitir essa apresentação do crítico, possibilitando novas leituras, mais específicas, e também relacionar, como dito, contexto e texto de forma recorrente. Se os dois primeiros capítulos, parecem voltar-se mais ao contexto, os dois últimos parecem incidir sobre o texto, há, no entanto, nos quatro, ao menos a intenção, de que as ideias apresentadas e comentadas do autor encontrem sua explicação em um fundo histórico, cuja materialidade pode ser vista pela relação entre o campo literário, com suas próprias demandas e tradição, e os demais campos sociais com os quais o crítico interagia.

Por isso também, com esse objetivo de apresentar a obra e, mesmo que de forma limitada, o contexto de produção, o capítulo final acaba afirmando algo que a historiografia confirmou: o papel secundário de Nestor Vítor. E, nesse ponto, convirjo com a historiografia oficial por uma perspectiva diferente, que é a das "apostas" que o crítico fez ao longo da vida. As apostas políticas, sociais, literárias também determinaram o lugar de Vítor na história da literatura brasileira.

A sua primeira aposta, em torno da poesia de Cruz e Sousa, foi, sem dúvida, a mais acertada. $\mathrm{O}$ crítico permanecerá na história literária enquanto permanecer o nome daquele, o que não é injusto realmente, considerando a quantidade de textos e referências ao poeta simbolista na produção crítica de Vítor. O mesmo não se pode falar sobre os escritores neossimbolistas e da corrente espiritualista do modernismo que ele viria a apoiar entre os anos de 1910 a 1930.

Com a apresentação da leitura dos modernistas, acredito que consegui traçar um panorama bastante amplo da crítica de Nestor Vítor, mostrando as várias facetas de um crítico que, tendo percorrido toda o período da República Velha, encerrou em sua obra muitos dos impasses que a geração seguinte começaria a responder: a apreciação, sobretudo, "estética" dos textos literários, a dialética entre o cosmopolitismo e o nacionalismo, a relativização dos períodos literários e dos movimentos correspondentes e, sobretudo, a questão da conquista da 
autonomia do campo literário diante das demais esferas da sociedade, a partir da crítica recorrente ao meio cultural.

Se o presente trabalho conseguiu delinear, ainda que brevemente, alguns desses impasses ao mesmo tempo que objetivou apresentar e difundir a obra de crítica de Nestor Vítor, conseguiu atingir o seu objetivo. 


\section{REFERÊNCIAS BIBLIOGRÁFICAS}

Obras de Nestor Vitor

VÍTOR, Nestor. Obra Crítica de Nestor Vítor. Volume 1. Rio de Janeiro: Fundação Casa de Rui Barbosa, 1969.

Obra Crítica de Nestor Vítor. Volume 2. Rio de Janeiro: Fundação Casa de Rui Barbosa, 1973.

. Obra Crítica de Nestor Vítor. Volume 2. Rio de Janeiro: Fundação Casa de Rui Barbosa, 1979.

. “Cruz e Sousa”. In: Cruz e Sousa. Coleção Fortuna Crítica. Organizada por Afrânio Coutinho. Rio de Janeiro: Civilização Brasileira; Brasília: INL, 1979.

Demais obras

ARARIPE JÚNIOR. Obra Crítica de Araripe Júnior. Volume I. Rio de Janeiro: Fundação Casa de Rui Barbosa, 1958

Obra Crítica de Araripe Júnior. Volume II. Rio de Janeiro: Fundação Casa de Rui Barbosa, 1960.

- Obra Crítica de Araripe Júnior. Volume III. Rio de Janeiro:

Fundação Casa de Rui Barbosa, 1963.

ARAÚJO, Cláudia Beatriz Carneiro. "Festa e o Modernismo". In: Revista Linguagem Estudos e Pesquisas. Vol. 15, n. 01. Catalão: UFG, 2011, p. 97-109.

ASSIS, Machado de. Obra completa. Volume III. Rio de Janeiro: Nova Aguilar, 1994.

BARBOSA, João Alexandre. A tradição do impasse; linguagem da crítica e crítica da linguagem em José Veríssimo. São Paulo: Ática, 1974.

BONET, Carmelo M. Crítica literária. São Paulo: Editora Mestre Jou, 1969.

BOSI, Alfredo. A literatura brasileira: O Pré-Modernismo. Vol. V. $3^{\text {a }}$ Ed. São Paulo: Editora Cultrix, 1969.

. História concisa da literatura brasileira. São Paulo: Cultrix, 2006.

"Introdução". In: Araripe Júnior: teoria, crítica e história literária. Rio de Janeiro, Livros Técnicos e Científicos; São Paulo: Edusp, 1978. 
. "Poesia versus racismo". In: Revista Estudos Avançados, vol. 16, no 44. São Paulo: IEA, jan./abr, 2002, p. 233-53.

BOURDIEU, Pierre. A Distinção: a crítica social do julgamento. $2^{\mathrm{a}}$ ed. rev. Porto Alegre, RS: Zouk, 2017.

. A economia das trocas simbólicas. 5a ed. São Paulo: Perspectiva, 2004. . As regras da arte. São Paulo: Companhia das Letras, 1996.

. Meditações pascalianas. Rio de Janeiro: Bertrand Brasil, 2001.

BRAGA-PINTO, César. “As amizades heteróclitas de Nestor Vítor (Cruz e Sousa e Lima Barreto)". In: Escritos. Revista da Fundação Casa de Rui Barbosa. Ano 4, n. 4. Rio de Janeiro: Fundação Casa de Rui Barbosa, 2010

BRITO, Faria. A verdade como regra das ações: ensaio de filosofia moral como introdução ao estudo do direito. Brasília: Senado Federal, Conselho Editorial, 2005.

BRITO, Mário da Silva. Antecedentes da Semana de Arte Moderna. Rio de Janeiro: Civilização Brasileira, 1964.

BROCA, Brito. A vida literária no Brasil - 1900. $3^{\text {a }}$ ed. Rio de Janeiro: José Olympio, Departamento de Cultura da Guanabara, 1975.

BRUNETIÈRE, Ferdinand. "Symbolistes et Décadents". In: Revue des Deux Mondes. Tome Quatre-Vingt-Dixième. Paris: 1888, p. 213-26. Disponível em: https://www.unidue.de/lyriktheorie/scans/1888 brunetiere.pdf. Acesso em 22/09/2018.

CAIRO, Luiz Roberto. O Salto por cima da própria sombra. O discurso crítico de Araripe Júnior: uma leitura. São Paulo: Annablume, 1996.

CANDIDO, Antonio. "Literatura e Cultura de 1900 a 1945". In: Literatura e Sociedade. 9a ed. Rio de Janeiro: Editora Ouro Sobre Azul, 2006.

. O método crítico de Sílvio Romero. $4^{\mathrm{a}}$ ed. Rio de Janeiro: Ouro sobre

Azul, 2006b.

Formação da Literatura Brasileira: momentos decisivos. Volume 2.

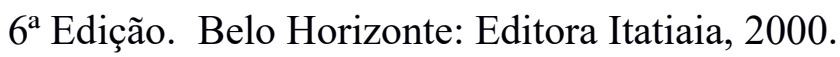

CANDIDO, Antonio; CASTEllo, Aderaldo. Presença da literatura brasileira - Do Romantismo ao Simbolismo. Rio de Janeiro: DIFEL, 1978.

CARA, Salete de A. A recepção crítica: o momento parnasiano-simbolista no Brasil. São Paulo: Editora Ática, 1983. 
CAROLlO, Cassiana Lacerda. Correspondência inédita de Nestor Victor dos Santos a Emiliano Perneta: 1911/1912. Curitiba: Revista Letras, 1975, p. 309-26. Disponível em: https://revistas.ufpr.br/letras/article/download/19612/12823. Acesso em 15 de abril de 2018.

Decadismo e Simbolismo no Brasil. Crítica e Poética. 2 volumes. Rio de Janeiro: Livros Técnicos e Científicos; Brasília: INL, 1981.

CARPEAUX, Otto Maria. História da literatura universal. Vol. IV. $3^{\text {a }}$ Edição. Brasília: Senado Federal, Conselho Editorial, 2008.

Pequena bibliografia crítica da literatura brasileira. Rio de Janeiro: Edições de Ouro, 1967.

CARVALHO, Alessandra I. Nestor Vítor: um intelectual e as ideias do seu tempo - 18901930. Curitiba: Aos Quatros Ventos, 1998.

CARVALHO, Ronald de. Pequena história da literatura brasileira. $8^{a}$ Edição. Rio de Janeiro: F. Briguiet \& Cia Editores, 1949.

COUTINHO, Afrânio. A literatura no Brasil. Volume 4. Era realista. Era de transição. São Paulo: Editora Global, 2002.

CRUZ E SOUSA, João da. Obra completa. Notas de Afrânio Coutinho. Org. Andrade Muricy. $2^{\mathrm{a}}$ reimpressão da $1^{\text {o }}$ Edição (atualizada em 1995). Rio de Janeiro: Nova Aguilar, 2000.

DO RIO, João. O momento literário. Rio de Janeiro: Fundação Biblioteca Nacional, 1994.

EAGLETON, Terry. A função da crítica. São Paulo: Livraria Martins Fontes, 1991. A ideia de cultura. São Paulo: Editora Unesp, 2011.

FAUSTO, Boris. História Concisa do Brasil. São Paulo: EdUSP, Imprensa Oficial do Estado, 2001.

GOMES, Álvaro Cardoso. A estética simbolista. Seleção de textos. São Paulo: Cultrix, 1985. GONÇALVES, Rosana. A evolução do pensamento crítico de Nestor Victor n’A Crítica de Ontem. Dissertação de Mestrado. Assis: UNESP, 1996.

Nestor Vítor: contribuições teóricas, críticas e históricas. Tese de doutorado. Assis: UNESP, 2004.

HELENA, Lucia. Modernismo brasileiro e vanguarda. São Paulo: Editora Ática, 2003.

LAFETÁ, João Luiz. 1930: A crítica e o modernismo. São Paulo: Duas Cidades; Ed. 34, 2000. 
LIMA, Alceu Amoroso. “O crítico do simbolismo”. In: Estudos Literários. Rio de Janeiro: Aguilar Editora, 1966.

LIMA, Luiz Costa. Dispersa Demanda. Rio de Janeiro: Livraria Francisco Alves, 1981.

LINHARES, Temístocles. História crítica do romance brasileiro. Belo Horizonte: Itatiaia; São Paulo: EDUSP, 1987.

LINS, Vera. Novos pierrôs, velhos saltimbancos: os escritos de Gonzaga Duque e o final do século XIX carioca. 2a ed. Rio de Janeiro: EdUERJ, 2009.

LÖWY, Michael; SAYRE, Robert. Revolta e Melancolia: o romantismo na contramão da modernidade. Petrópolis: Editora Boitempo, 2015.

MACHADO NETO, Antônio Luis. Estrutura social da república das letras: sociologia da vida intelectual brasileira, 1870-1930. São Paulo, Grijalbo, Ed. da Universidade de São Paulo, 1973.

MAgalhães JúNiOR, Raimundo. Poesia e vida de Cruz e Sousa. $2^{\text {a }}$ edição. São Paulo: Lisa; Rio de Janeiro: INL, 1972.

MARTINS, Wilson. A crítica literária no Brasil. Vol. I. Rio de Janeiro: Francisco Alves, 1983.

MERQUIOR, José Guilherme. De Anchieta a Euclides: breve história da literatura brasileira. Rio de Janeiro: José Olympio, 1977.

MICELI, Sérgio. "Poder, sexo e letras na República Velha”. In: Intelectuais à brasileira. São Paulo: Companhia das Letras, 2001.

MURICY, Andrade. Panorama do Movimento Simbolista. Vol. 1. 2 ed. Brasília: Conselho Federal de Cultura e Instituto Nacional do Livro, 1973.

. "Introdução". In: Obra crítica de Nestor Vítor. Vol. I. Rio de Janeiro:

Fundação Casa de Rui Barbosa, 1969.

NAGLE, Jorge. "A Educação na Primeira República”. In: História Geral da Civilização Brasileira. O Brasil Republicano. Tomo III. Volume 2. 3ª Edição. São Paulo: Difel, 1985.

NEEDELL, Jeffrey D. Belle Époque Tropical. Sociedade e cultura de elite no Rio de Janeiro na virada do século; tradução Celso Nogueira. São Paulo: Companhia das Letras, 1993.

NUNES, Benedito. “A visão romântica”. In: O Romantismo. Org. Jacó Guinsburg. São Paulo: Editora Perspectiva, 1993.

OLIVEIRA, Vera Lúcia de. Poesia, mito e história no Modernismo brasileiro. São Paulo: Editora UNESP; Blumenau, SC: FURB, 2002. 
PAULA, Douglas Ferreira de. Mescla estilística e ambiguidade em Broquéis de Cruz e Sousa. Dissertação de Mestrado. São Paulo: Universidade de São Paulo, 2013.

PEYRE, Henri. A literatura simbolista. São Paulo: Cultrix; EDUSP, 1983.

PINHEIRO, Paulo Sérgio. “Classes Médias Urbanas: Formação, Natureza, Intervenção na vida política”. In: História Geral da Civilização Brasileira. O Brasil Republicano. Tomo III.

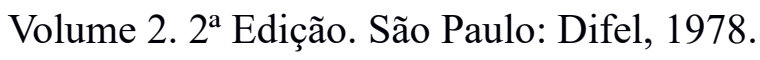

PRADO, Antonio A. 1922 - Itinerário de uma falsa vanguarda: os dissidentes, a Semana e o Integralismo. São Paulo: Brasiliense, 1983.

ROMERO, Sílvio. Evolução do Lyrismo Brazileiro. Recife: J. B. Edelbrock, 1905. Zeverissimações ineptas da crítica. Porto: Oficinas do Comércio do Porto, 1909.

RONCATO, Maria Aparecida. Nestor Vítor: a atividade crítica como e enquanto projeção de um modelo ideológico. Dissertação de Mestrado. Rio de Janeiro: PUC-RJ, 1979.

SEVCENKO, Nicolau. Literatura como missão: tensões sociais e criação cultural na Primeira República. $2^{\mathrm{a}}$ ed. São Paulo: Companhia das Letras, 2003.

SILVEIRA, Allan Valenza. Diálogos críticos de Nestor Vítor. Tese de Doutorado. Curitiba: Universidade Federal do Paraná, 2010.

SILVEIRA, Tasso. “Apresentação”. In: Nestor Vítor - prosa e poesia. Rio de Janeiro: Agir, 1963.

SIMÕES JÚNIOR, Alvaro Santos. “A repercussão nos jornais de livros simbolistas de 1899”. In: Revista Remate de Males. Número 29, jul/dez de 2009. Campinas: Revista do Departamento de Teoria Literária da Unicamp, 2009, p. 247-58. . "Fantos, Broquéis e a poesia nova de 1893". In: Revista

Entrelaces. Ano III, número 03, novembro de 2013. Fortaleza: Revista do Programa de PósGraduação em Letras da UFC, 2013, p. 04-15.

SOUZA, Luiz Alberto de. "Os desclassificados do destino": Cruz e Sousa e os primeiros simbolistas (Rio de Janeiro, 1888-1898). Tese de Doutorado. Florianópolis: Universidade Federal de Santa Catarina, 2017.

STEGAGNO-PICCHIO, Luciana. História da literatura brasileira. Rio de Janeiro: Nova Aguilar, 1997.

TELES, Gilberto Mendonça. Vanguarda Europeia e Modernismo Brasileiro: apresentação e crítica dos principais manifestos vanguardistas. Petrópolis: Editora Vozes, 1977 
VALÉRY, Paul. “Existência do simbolismo”. In: Variedades. São Paulo: Iluminuras, 2011. VENTURA, Roberto. Estilo Tropical. História Cultural e Polêmicas Literárias no Brasil. São Paulo: Companhia das Letras, 1993.

VERÍSSIMO, José. Estudos de Literatura Brasileira. Primeira Série (1895-1898). Rio de Janeiro-Paris: Editora Garnier, 1901.

VERÍSSIMO, José. José Veríssimo: teoria, crítica e história literária. Seleção e apresentação de João Alexandre Barbosa. Rio de Janeiro: Livros Técnicos e Científicos; São Paulo: Editora da Universidade de São Paulo, 1977.

VIVEKANANDA, Swami. Alma e coração de Nestor Vítor. Paranaguá, PR: Conselho Municipal de Cultura, 1973.

WELLEK, René. História da Crítica Moderna: 1759-1950. Volume 4. São Paulo: Editora Herder, Editora da Universidade de São Paulo, 1972.

WILLIAMS, Raymond. "Base e superestrutura na teoria da cultura marxista". In: Cultura e Materialismo. São Paulo: Editora UNESP, 2011. 